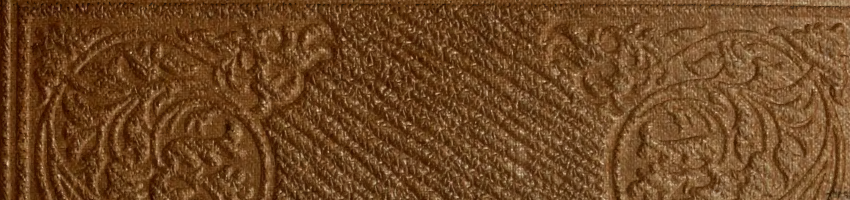
it the

(1)

$(9)$
$(19)$
$(1)$

(b)

$\frac{4}{4}$

in

190 - 





A2Z CONTRIBUTIONS

Moll.

\author{
тo \\ C 0 N C H 0 L 0 G I:
}

CONDUCTED BY

C. B. ADAM S,

PROPESSOR OF ZOOLOGY IN AMHERST COLIEGE, MAss.

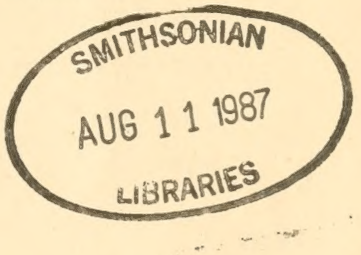

VOLUME I.

OCTOBER, 1849-NOVEMBER, 1852.

124094

N E W Y O R :

H. BAILLIÉRE, No. 290 BROADWAY;

219 REGENT ST, LONDON; AND 19 RUE HAUTEFEUILLE, PARIS. 



\title{
CONTENTS OF VOL I.
}

\author{
BY C. B. ADAMS.
}

Deseriptions of forty-four new species and varieties of operculated land shells from Jamaica. September 1849. - - - - - - - 1-14

Catalogue of operculated land shells which inhabit Jamaica. - _ _ 15-16

Deseriptions of supposed new species and varieties of Helicidæ from Jamaica, October 1849. - _ _ _ _ _ _ _ _ - 17-38

Catalogue of species and varieties of Helicidæ which inhabit Jamaica. - 39-41

New Auriculidæ which inhabit Jamaica. Oet. 1849. - _ - . 41-42

Catalogue of Auriculidæ which inhabit Jamaica. Oct. 1849. - _ _ $\quad 42$

Deseriptions of supposed new species of freshwater shells which inhabit Jamaica. Oct. 1849. - - _ - - - - - - - 42-45

Catalogue of freshwater shells which inhabit Jamaica. Oct. 1849. - - $\quad 45$

Remarks on the distribution of the terrestrial and freshwater Mollusea which inhabit Jamaica. Oet. 1849. - - - - - - - 45-50

Remarks on the weight of the shells of certain species of Colimacea. Nov. 1849. -

Deseription of a supposed new species of Columbella Jan 1850. - 53-54

Notes on the synonymy of certain marine shells. Jan. 1850. - _ _ 54-55

Descriptions of supposed new species of marine shells which inhabit

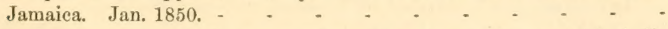

Descriptions of supposed new species and varieties of terrestrial shells which inhabit Jamaica. Feb. 1850. - - - - - - -

Remarks on the origin of the terrestrial Molluses of Jamaica. Mareh 1850.

Description of a new genus of Helicidæ from Jamaica. March 1850. -

Deseription of Jamaicia, a new subgenus of Cyelostoma. March 1850. -

Notes on certain species of the land shells of Jamaica. March 1850. -

Descriptions of supposed new species of land shells which inhabit Jamaica. March 1850.

Synonymy of Helix picturata Ad. - _ - - - - - - 98-100

Deseription of supposed new species of land shells which inhabit Jamaica. April 1850. -

Descriptions of supposed new species of marine shells which inhabit Jamaica. April 1850. - - _ _ - . - - - 109-123

Deseriptions of new species of Partula and Achatinella. Oct. 21st, 1850. 125-128

Deseriptions of new species and varieties of shells which inhabit Jamaica. Oet. 21st, 1850.

Analysis of the group of species of Cyclostoma, which is represented by C. Jamaicense Chem. 
On the genus Stoastoma. Oct. 21, 1850.

Descriptions of new species and varieties of the land shells of Jamaica, with notes on some previously deseribed species. April 1851. - - 158-174

Descriptions of new freshwater shells, which inhabit Jamaica. April 1851. - - - - - - - - - - - - - 174-175

Catalogue of the land shells which inhabit Jamaica. April 1851. - - 179-186

Catalogue of the freshwater shells which inhabit Jamaica, April 1851. - 187

On the nature and origin of the species of the terrestrial Mollusea in the

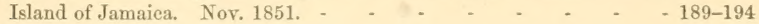

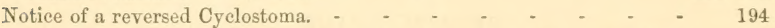

On the value of the shells of Mollusca for the purpose of distinguishing species and higher groups. Nov. 1851. - _ - - - - 194-203

Remarks on certain Helices which are described and figured in the

Conchologia Ieonica for October, 1851. Nov. 1851. - - - $\quad$ - 205-206

Hints on the geographical distribution of animals, with special reference

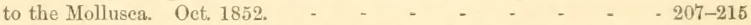

Deseriptions of new species of Corbula from Jamaica, \&c. Oct. 1852. - 233-241

Catalogue of Species of Lucina, which inhabit the West Indian Seas.

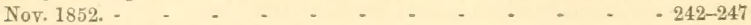

BY C. B. ADAMS AND EDWARD CHITTY.

Remarks on the habitats of certain species of land shells, April 1851. - 176-177

\section{BY THOMAS BLAND.}

Catalogue of the terrestrial shells of St. Thomas, W. I. Oet. 1852. - $\quad-215-224$

On the Clausiliæ of America. Oct. 1852. - - - - - - $\quad$ - 224-228

Catalogue of terrestrial shells collected by T. Bland in New Grenada in 1851. Oct. 1852 .

The same, continued. - $\quad$ - $\quad$ - $\quad$ - $\quad$ - $\quad$ - $\quad$ - 231-238

Notice of Petit's Journal de Conchyliologie, \&c. - _ - _ - - 241-242

Notice of Poey's Memorias sobre la Historia Natural de la Isla de Cuba, \&c., 1851. 


\title{
Goutributions to Gouchec.py

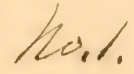

\section{METRIPTONS OH TORTY-FOUR SUPPOSLD NEW SPL-

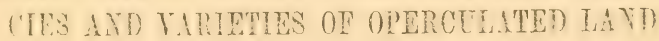 SHELLS FROII JAMIAICA.}

\author{
BY C. B. ADAMS, \\ Professor of Zoology, etc., in Amherst College, Mnssachusetts. \\ SETEMRER, 1849 .
}

1. Crclostona Chitryi. This species differs from $C$. fimloriatulum Sow ${ }^{2}$. in the smaller and more closely set spiral carina, of which there are three more on each whorl, - and by the scollops of the outer perifreme, which are smaller and more numerous, corresponding with the carinæ.

The many individuals of $\mathrm{C}$. fimbriatulum which $\mathrm{I}$ have seen are quite constant in their peculiarities. Of C. Chittyi, however, I haw but one individual. The value of the speciss will be more ertainly established by the discovery of additional specimens.

2. Ciclostoma sprixtosum. Shell short, globose-conic; dingy white, with several more or less interrupted brown spiral lines; with crowded transwerse thin perpendicular lamelle, which are decuseated by numerous rather strong raised spiral lines, of which three about the middle of the whorls are larger; the points resulting from the decussation are elevated into minute spines where protected in the angle of the deep suture; spire with very convex ontlines; apex usually trumcate with the loss of two whorls; three and one lialf whorls remaining, very convex; last who:l a little detached from the penult whorl near the aperture, but soldered to it by the onter peritreme; aperture exactly circular; inner peritreme much prociuced, striated parallel to the edige on the outside; outer peritreme moderately expanded and reflected convexly back of the plane of the aperture, finely seollope: with the ends of the spiral lines, and deeply strinted paraliel to the

* The writer is engaged in the preparation of a monbgraph of the land shells of Jamaica, and will thankfu!ly receive any criticism or informativn, which nay promote its completeness and correctness. 
scollops; umbilicus moderately wide, extending throngh the truncate. apex.

Mean divergence $75^{\circ}$; length .5.) inch; greatest brea!th .5.5 inch; least breadth .38 inch.

The spiral lines, as usual in this group, do not appear on the first whorl, but only on the last three.

3. Crclostoma aculeosum. Shell short, globose-conic; dingy white; with crowded transwerse thin perpendicular lamellac, which are decussated by numerous thin prominent spiral lines, with the points of intersection produced into slender spines, especially in the angle of the deep suture, the spiral lines appearing on the last three whorls; spire with very conrex outlines; apex truncate with the loss of two whorls, three and one half whorls remaining, very convex; last whorl a little detached from the penult whorl near the aperture, but soldered to it by the outer peritreme; aperture exactly circular; inner peritreme weil produced; outer peritreme well expanded, scolloped and striated as in the preceding; umbilicus moderately wide, extending through the truncate apex.

The spiral lamella of the operculum is extremely high and but slightly reflected outwards.

Iean divergence $77^{\circ}$; length .56 inch; greatest breadth .6 inch; least breadth .38 inch.

4. Crclostoma amabile. Shell globose-conic; dingy or brownish white, with the peritreme radiated with brown; with very numerous transverse thin perpendicular lamella, which are decussated and aculeated by numerous spiral very delicate lines, which appear only on the last three whorls; spire with very convex outlines; apex usually truncate, with the loss of less than two whorls; three and one half whorls remaining, with a rather deep suture; last whorl not at all detached from the penult whorl; aperture exactly circular; inner peritreme well produced; outer peritreme greatly expanded, very deeply striated with the lamella of growth, which are pectinated parallel to the numerous scollops made by the ends of the spiral lines, perpendicular and less developed against the penult whorl, sinuate and yet more expanded above; umbilicus exhibiting all the whorls and extending through the truncate apex.

The spiral lamella of the operculum is much less elevated than in the preceding, and slopes outward much more. The sculpture of the shell is finer, the umbilicus is narrower, and the peritreme is much more expanded.

Mean divergence 75 ; length .5 inch; greatest breadth .5.5 inch ; least breadth .35 inch. 
7. Crclostoma amandum. Shell short, globose-conic ; dingy white with three principal and often other brown more or less interrupted spiral bands; with quite regular prominent lamella of growth, which are decussated and aculeated by very numerous close-set spiral lines, that appear only on the last three whorls and are most conspicuous just below the suture; spire with very convex outlines; apex truncate with the loss of two whorls; three and one half remaining, very convex, with a deep suture; last whorl a little detached from the penult whorl near the aperture, but soldered to it by the outer peritreme; aperture exactly circular, inner peritreme much produced, regularly striated on the outside parallel to the edge; outer peritreme finely scolloped with the termination of the spiral lines; umbilicus extending through to the truncate apex, and exhibiting all the whorls.

Miean divergence $88^{\circ}$; length .55 inch; greatest breadth $.63 \mathrm{inch}$; least breadth .43 inch.

6. Crclostoma Blandianum. Shell like $C$. lima, Ad. but the spiral lines are less distinct, and both the spiral and transverse lines are finer and more closely set; the shell is shorter and the whorls are narrower ; color pale brown to white, with more or less distinct interrupted spiral brown lines; outer peritreme very much expanded, especially on the left side, slightly crenulated, above produced into a broad sinus; umbilicus narrow and extending through the truncate apex.

Mean divergence $60^{\circ}$ to $62^{\circ}$; length .7 inch; greatest breadth .65 inch; least breadth .45 inch.

7. Cyclostoma variabile. Shell moderately elongate, ovate conic; deep blackish blue when fresh, fading by exposure into pale yellowish brown, and then developing on the upper whorls two and on the last whorl three somewhat interrupted spiral brown lines and intermediate series of small brown spots, with a series just below the suture of large square spots, with a wax-yellow lip; with very fine spiral strix on the last three whorls, decussated by very close-set rounded ridges of growth, most of which are gathered in the suture into minute white crenulations; spire with very convex outlines; apex truncate with the loss of three to three and one half whorls; four whorls remaining, which are quite convex and very slightly angular above the middle, with the suture rather deep; aperture circular; outer peritreme at first rather thin smooth, and polished; in the old, the lip is filled between its moderately produced inner and outer margins with a solid deposit concentrically striated, not scolloped; umbilicus small, exhibiting but a part of the last whorl, extending through the truncate apex.

Menn divergence $13^{\circ}$ : length . .3:3 inch ; greatest breadth .34 inch: least breadth .26 inch. 
S. Crerostom concentrour. This may be a variety of $C$ m merite bile; it is chicfly distingili-hed by having the lamellar between the inner and outer peritremes se much produced is th appear like numerous concentric margins; by having the lip reflected farther back; by a more slender gencral form, the mean divergence being $3: 3^{\prime}$ to $335^{\circ}$. The lip is reldish parple, with darker rays of the same conspicuous in the more simple lip of the yonng, and the square sutural spots are always faint.

9. Crelostous serrierum. Shell ovate-conic, molerately elongate; reddish brown, with a series of rather dark spots of the same; with very thin and sharp tranverse perpendicular rather distant lamella", which are serrated by a few faintly impressed spiral lines : spire with convex outlines; apex truncate with the loss of about three whorls; remaining whorls four and one half, moderately convex, with a well impressed suture; last whorl scarcely detached from the penult whorl near the aperture, which is orbicular; inner peritreme not produced (?) ; outer peritreme shining, well expanded, cxcept opposite to the penult whorl ; umbilicus narrow, but extending through the truncate apex.

Mean divergence about $40^{\circ}$; length $5 \%$ inch; greatest breadth .3.5 inch; least breadth .275 inch.

This may possibly be an accidental variety of $C$. Grayamum or of some other of this group. The only specimen which I have does not appear to have the lip fully developed with age.

10. Cyclostoma decussitclum. Shell moderately elongate, ovate conic; whitish, with brown spiral bands, which are more distinct on the lower whorls; elegantly and finely decussated with numerous close-set transwerse strong .rounded raised lines; spire with convex outlines: apex truncate with the loss of two or two and one half whorls; four and one half to five whorls remaining, convex, with a deep suture; aperture nearly circular; inner peritreme moderately produced and reflected; outer peritreme moderately expanded, concentrically striated; umbilicus narrow, but extending through the truncate apex.

Mean divergence about $50^{\circ}$; length $.5-5$ inch; greatest breadth .42 inch; least breadth .32 inch.

This species does not answer to the description and figures of $C$. mirabile, Gray, to which it must be nearly allied.

11. Cyclostoma manandm. Shell elongate, conic; brownish white, with a series just helow the suture of large distant square brown spots, and with on the nyper wherls three, and on the last five narrow somewhat interrupted brown piral lines: covered with closely-set. rounded transreree raised lines: which are decussitely crenulated by 
numerous faint spiral stria ; spire with moderately coniex outlines; apex truncate with the foss of two or iwo and one half whorls; four or four and one half whoils remaining, convex, with a deep suture; aperture almost exactly circular; inner peritreme of old shells produced to an extraordinary degree, with a few distant lamellar grirdling the outside; outer peritreme considerably produced, retlected a little back of the plane of the aperture, slightly striated, shining; umbilicus small, extending through the truncate apex.

Mean divergence $10^{\circ}$; lenrth .7 inch; greatest brealtil .45 inch; least breadth .37 inch.

12. Cyclostomi mormurdum. Shell clongate, ovate-conic; whitish, with a few pale brown spots just below the suture, and often with several much interrupted spiral series of the same color, with a deep brownish ptrple summit and a lip of wax-yellow; with closely set regular rounded transwerse raised lines, which are decussatcly crenulated by numerous faint spirai stria'; spire with noderately convex outlines; apex truncate with the loss of two or three whorls; four whorls remaining, with a deep suture, the last a little detached from the preceding near the aperture, which is ovate orbicular and sulsangular above; inner peritreme a little produced and reflected; nuter peritreme moderately expanded, concave, and forming with the imer one a groove, striate, subalate above, narrow on the left side; umbiliicus narrow, extending through the truncate apex.

Mean divergence $36^{\circ}$; length . is inch; greatest breadth .36 inch: least breadth .28 inch.

13. Cxclostoni intermenim. Species intermediate between $\mathbb{C}$. variabile and C. monstroszen. Shell sculptured and colored like the pale varieties of C. variabile, with the large sutural spots loss distinct; whorls of less diancter than in that species but larger than in C. monstrosum; apex truncate with the loss of three whorls, four remaining, quite convex, with a rather deep suture; last whorl much detached from the penult whorl; aperture larger than in C. monstrosum, with the peritremes similar, but the outer one is less expanded.

Mean divergence abont $3 \mathrm{n}^{\circ}$; length .5 inch; greatest breudth .; inch; least breadth, . .27 inch.

14. Cycrostom moxstroscu. Shell modernaty elongate; tranlucent, whitish, with unequal irregular brown spots, which are arranged for the most part in transwerse bands, with the largest spots just lefow the suture: rery fioly decussted, but with the senpture indistinct near the aperture; spire with convex ontlines; apex truncte with the loss of two or three whorls; absut four and one half remaining, very 
convex, with a very deep suture; last fourth part of the last whorl diverging very abruptly and very far from the penult whorl; aperture small, exactly circular; inner peritreme moderately produced; outer peritreme enormously expanded, except on the inner side, convexly reflected back of the plane of the aperture, smooth and shining, with reddish brown rays; umbilicus narrow, but very plainly extending through the truncate apex.

Mean divergence about $35^{\circ}$; length .56 inch ; greatest breadth .38 inch; least breadth .27 inch.

15. Crclostoma Wilinsonir. Shell small, subcylindrical; whitish, with a few small distant pale brown spots in a spiral series; with not very closely set sharp transverse raised lines; spire with slightly convex outlines; apex truncate with the loss of three whorls, of which the second and third are seen in the young shell to be entircly and widcly detuched; four whorls remaining, very convex, with a very deep suture; last whorl widely detached from penult whorl near the aperture, acutely angular above; aperture suborbicular, quite angular above; inner peritreme moderately produced; outer peritreme rather small, concentrically striated, refiected a littic back of the plane of the aperture, above produced into an angle, with two or three small brown spots; umbilicus very small, but extending through and spreading near the apex.

Nean divergence about $17^{\circ}$; length .35 inch; greatest breadth .16 inch; least breadth .12 inch.

16. Cyclostona avena. Shell small, elongate; whitish, more or less tinged with brown, with numerous small distant brown dots in spiral series on the lower whorls, on the upper whorls blueish gray; with closely set transverse moderately elevated lines, some of which, in twos or rarely in threes, are more developed at the sutures into small white cremulations; spire with moderately convex outlines; ap $2 x$ truncate with the loss of two or three whorls; about four and one-half whorls remaining, very convex, with a deep suture; last whorl much detached from the penult whorl near the aperture; aperture suborbicular, contracted a little on the left side; inner peritreme a little produced; outer peritreme rather small, much less extended on the left than on the riglit side, not reflected quite back to the plane of the aperture, produced above into a concave angle; umbilicus very small.

Mean divergence $2: 3^{n}$; length .32 inch; greatest breadth .14 inch; lenst breadth .11 incl.

17. Crciostoma monestum. Shell small, elongate; whitish; with thin raised lamina, which are more distant on the upper whorls; spire with moderately conrex outlines; apex truncate with the luss of two or 
three whorls; about three and one-half whorls remaining, quite convex, with a rather deep suture; last whorl a little detached from the preceding near the aperture; aperture like that of $\mathrm{C}$. Wilkinsonii, but smaller, with the outer peritreme a little wider proportionally and without spots; umbilicus very narrow, but extending through.

Mean divergence about $25^{\circ}$; length .26 inch; greatest breadth .15 inch; least breadth .11 inch.

18. Crchostuma solidum. Shell long, orate-conic; whitish or brownish, with several narrow more or less interrupted sometimes nearly obsolete spiral brown lines, often with large irregular zigzag oblique spots of dark brown; with very closely set strong rounded transverse raised lines, which are a little larger in twos and threes at the summit like a minute crenulation; spire with moderately convex outlines; apex truncate with the loss of two whorls; four and one-half whorls remaining, quite convex, with a well impressed suture; aperture nearly ciruclar; inner peritreme slightly produced and reflected; outer peritreme broad, white or pale yellow, a little concare, widest above and on the left side at the bottom of which it is subangular; umbilicus, very small.

Mean divergence $50^{\circ}$; length . 5 inch ; greatest breadth .55 inch; least breadth .4 inch.

Var, $a$, with the outer peritreme fiery red. C. pictum, Humph. Mss., Sowb. resembles this species, but is smouth and has an extremely wide lip.

19. Crclostoma August.x. Shell much elongated, conic; shining, whitish or brownish, with six spiral series in three pairs of narrow dark brown spots which are cither ohlong or sagittate, the middle pair being more or less confluent, - with also a broad band and some more or less distinct lines of dark brown around the umbilical regrion; with transverse stria very strong on the upper whorls, and feeble and distant on the last whorl, decussated by faint spiral strie; spire with the outlines scarcely convex; apex truncate with the loss of two or three whorls; five whorls remaining, with a moderately impressed suture, which is subcrenulate by the enlargement of the upper ends of the transverse lines in twos and threes; aperture ovate-orbicular, oblique; inmer peritreme a little produced and reflected; outer peritreme well expanded, white, in some yellowish, more or less concave, much produced above and inflected forming a deep pit, before the unbilicus reflected far back into a derp sinus, with an alate expansion next to the sinus; unbllicus very small.

Mean divergence $33^{\circ}$; length .9 inch; greatest breadth .5.2 inch; least breadth $.4 \mathrm{inch}$. 
Var. $a$, with the outer peritreme deep red, and the spiral strix stronger; of which I have seen but two individuals.

39. Crenostona ploxnum. Species like C. fascia, Gray, but the shell is much more coarsely decussated, the transwerse lines being stronger and the spiral lines less numerons; the lip is less expanted and more solid, and the whole shell is thicker and smaller.

21. Crenostona Nawcommonew. Shell unch elongated, conic; very pale orange, elcrantly decorated with several spiral series of small brown oblinue spots which have white shadows, the spots boing in transverse series; with numcrous small bet strong transterse whitish raised lines, which are mostly in groups of three to five and at the summits are developed into minute sutural crentations; spire with slighly conves outlines; apex truncate with the loss of two or three whorls; five whorls remaining, with a well impressed suture; last whorl detached from the penult whorl near the aperture; aperture suborbicular, quite angular ahore; inner peritieme slighty produced; outer peritreme moderately expanding, shining, reflected exactly into the plane of the aperture, rather thick, nearly wanting opposite to the penult whorl, moderately produced abore into a sharply angular concave wing; umbilicus very small.

Mean divergence $33^{\circ}$; length $5: 2$ inch; greatest breadth . 8 inch; least breadth .22 inch.

2.). Crchostoma nitrexs. Shell moderateiy eiongated, conic; shining, brownish white with white spots, and spiral interrupted bands of pale brown, deep orange near the aperture; very finely decussate with nearly equal slightly elevated lines, but on the upper whorls the transverse lines are more prominent and the spiral ines obsolete; spire with the outines slightly convex; apex truncate, with the loss of two or three whorls; four whorls remaining, with a well impressed suture; aperture larece, orate orbicular, moderately angulated above; inner peritreme scarcely distinct, reflected upon the outer peritreme, which is reflected nearly into the plane of the aperture, is moderately spreading, sharp, thickened, narrower and bent back opposite the umbilicus, which is small.

Mean divergence $40^{\circ}$; length .36 inch; greatest breadth ..36 inch; least breadih .26 inch.

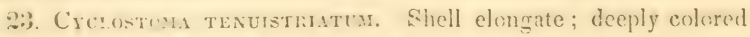
with greyish and reddish slate color, whth an orange lip; with numerous distinct spiral strit decussated by excessirely minute and numerour transwerce stria and by a few distant fine deep strix ; spire with moderately comex outlines; apes truneate with the loss of two or three whorls; four and one-hulf rather convex whorls remaining, with a 
rather deep suture ; aperture subelliptical ; lip solid ; inner peritreme scarcely produced; outer peritreme moderately expanded, thick, striated, edge blunt; umbilicus narrow, extending through.

Mean divergence $37^{\circ}$; length .5 inch; greatest breadth .3 inch; least breadth .23 inch.

Cyclostoma xanthostoma, Sowb., is more coarsely sculptured with less numerous spiral grooves, has sometimes the coloring of the above, but is more frequently horn colored.

24. Cусlostoma ignilabre. Shell elongate; varying in different individuals from a pale dingy brown to dark blueish slate color, but in all is deeply colored at the extremities, with a fiery red lip; with closely set strong transverse raised lines, which are decussated by many very faint stric; spire with moderately convex outlines; apex truncate with the loss of three whorls; four and one-half quite convex whorls remaining, with a deep suture; aperture and peritremes as in the preceding: umbilicus narrow, extending through.

Mean divergence $35^{\circ}$; length .5 inch; greatest breadth . 27 inch; least breadth .2 inch.

Var. $a$, with a white lip, and shell always pale dingy brown.

25. Cyclostoma pisum. Shell short, ovate conic; dark slate colored, with a red lip; with closely set strong transverse raised lines decussated by very faint spiral lines, which are obsolete on the upper whorls; spire with quite convex outlines; apex truncate with the loss of two and one-half whorls; three very convex whorls remaining, with a very deep suture; aperture circular; inner peritreme a little produced and reflected; outer peritreme much expanded, a little concave and faintly striate; umbilicus rather wide, extending through.

Divergence about $56^{\circ}$; length .33 inch; greatest breadth .315 inch; least breadth .215 inch.

26. Cyclostoma hyacintuinum. Shell ovate conic; deep greyish blue, often in the progress of growth becoming pale brown and then orange, always deep orange at the lip ; with rather strong but not very prominent often whitish transverse raised lines, which are mostly in groups of three or four, and are traversed by numerous spiral series of short rectangular obliquely situated indentations, which are of a dark brown in brownish parts of the shell,-with very unequal and inequidistant small crenulations in the suture; spire with rather convex outlines; apex truncate with the loss of two whorls; four quite convex whorls remaining, with a deep suture; aperture orbicular, slightly angulated above; inner peritreme slightly produced; outer peritreme narrow, concave, deeply striated, sharp-edged, wanting at the contact with the penultimate whorl, auriculate above; umbilicus extending through. 
Mean divergence $58^{\circ}$; length .58 inch; greatest breadth .45 incils: least breadth .35 inch.

Probably this is a variety of $\boldsymbol{C}$. Banksianum, which is more coarsely and conspicuously crenulated; but without authentic specimens of $\mathbf{C}$. Banksianum, I am unable to decide from the description and figures in the Thesaurus.

27. Cyclostoma Redfieldianum. Shell ovate-conic; pale blueish gray or dingy white, with a few spiral interrupted lines of dark brown; strongly striated transversely, without spiral strix; spire with rather convex outlines; apex truncate with the loss of two whorls; three and one-half quite convex whorls remaining, with a deep suture, which has a few strong unequal inequidistant crenulations; aperture large, nearly orbicular; inner peritreme a little produced and reflected; outer peritreme wanting on the upper part of the left side, much expanded on the remaining part of this side, moderately spread on the outer side, concave, sharp-edged, above often inflected so as to form a cell ; umbilicus small.

Mean divergence $55^{\circ}$; length .66 inch; greatest breadth .5 inch; least breadth .4 inch.

28. Cyclostona tectilabre. Shell ovate-conic; blueish horn colored, with several interrupted spiral brown lines; with rather closely set sharp elevated transverse lamellæ, without spiral strix; spire with quite convex outlines; apex truncate with the loss of two and one-half very small whorls; nearly four very convex whorls remaining, with a deep suture, aperture a little detached from the penult whorl, nearly orbicular, slightly angulated above; inner peritreme very slightly spread, but covering the outer one, which is extremely small; umbilicus small.

Operculum much larger than the aperture, with its margin reflected abruptly far behind the margin of the aperture!

Mean divergence $45^{\circ}$; length $.5: 3$ inch; greatest breadth .4 inch; least breadth .3 inch.

29. Cxclostom. armatum. Shell much elongated; brown, with a reddish and cinereous tinge, usually darker at the summit, rarely with a spiral series of dark brown spots; with very closely set strong transverse raised lines (the whitish color of which gives the ashy tinge to the general aspect), which at the upper extremity are enlarged, mostly in fours with one unenlarged line between, into a closely set series of strong sutural crenulations,-without spiral striæ; spire with outlinns scarcely convex; apex truncate with the loss of two and onc-linilf whorls; five moderately convex whorls remaining, with a well impressed suture ; last whorl near the end a little detached from the pre- 
ceding; aperture orate-orbicular, well angulated above, white within next the lip, with the fauces yellowish brown; lips single, slightly spread and reflected into the plane of the aperture, a little alate at the angle; umbilicus very small.

Mean divergence $30^{\circ}$; length .64 inch; greatest breadth .35 inch; least breadth .26 inch.

30. Cxclostona nuticun. Species like C. armatum, but the shell is more slender; and more delicately striated transversely; the outlines of the spire are more convex; there are no sutural crenulations; the aperture is smaller, less regularly ovate, and more angulated above.

Mean divergence $22^{\circ}$ : length .57 inch; greatest breadth .27 inch; least breadth .23 inch.

31. Cxclostona fecunous. Shell much elongated, conic; brownish or reddish brown, sometimes with darker more or less transverse clouds, with numerous elegant spiral series of small dark brown spots, which are arranged at unequal distances in transverse lines, and are most conspicuous in the young shell, disappearing with age; with transverse striæ like C. armatum, and spiral faintly impressed lines on the upper whorls; spire with scarcely convex outlines; apex truncate with the loss of three whorls; five rather convex whorls remaining, with a moderately impressed suture; aperture large and spreading, less oblique than in the two preceding species, ovate, much angulated and extended into a sinus above; lip single, rather thin, a little spreading, scarcely reflected back to the plane of the aperture; umbilicus small, with rather strong spiral striæ.

Mean divergence $33^{\circ}$; length .22 inch; greatest breadth .37 inch; least breadth .3 inch.

Var. distinctum, with the aperture a little detached from the last whorl.

32. Cyclostoma aurora. Shell much elongated, ovate-conic; very pale orange, sometimes with very faint spiral darker lines, white next the aperture; with very strong not closely set whitish transverse raised lines, and two or three very faintly impressed spiral strix on the upper part of the whorls; spire with slightly convex outlines; apex truncate with the loss of three whorls; four and one-half whorls remaining, moderately convex, with a well impressed suture; aperture ovate, moderately spreading, appressed a little to the penult whorl below the angle above, which is detached; lip rather thin, scarcely spreading and but little reflected, umbilicus very small, with strong spiral strix.

Mean divergence $30^{\circ}$; length .65 inch; greatest breadth. 31 inch; least breadth .26 inch.

Given to me in Jamaica as a native species. 
33. Crcrostonis momdax. Shell much elongated; pale brown, often at the summit deep reddish brown, with several spiral series of very small deep brown spots, of which those next below the suture are the larger, and a somewhat interrupted band of the same around the anterior extremity ; with closely set much elevated sharp transverse lamellæ, which are slightly crenulated by numerous spiral impressed lines, of wich one next below the suture is more deeply impressed; spire with scarcely convex outlines; apex truncate with the loss of nearly three whorls; nearly five quite convex whorls remaining, with a well impressed suture; last whorl a little detached from the penult whorl next the aperture; aperture ovate-orbicular; lip simple, slightly spread, reflected nearly into the plane of the aperture, more developed at the angle above, and more advanced in the middle of the right side; umbilicus very small.

Mean divergence $28^{\circ}$; length .58 inch; greatest breadth .32 inch; least breadth .25.

34. Cyclostoma quineue-Fasciatum. Shell much elongated; whitish with a faint tinge of brown, with-on the upper whorls three, and on the last whorl five spiral series of very dark brown spots which have pale brown shadows, the spots being also in inequidistant transverse lines; with rather distant smooth transverse ridges; spire with scarcely convex outlines; apex truncate with the loss of nearly four whorls; five whorls remaining, with a moderately impressed suture; aperture ovate, subangulated at each end; inner peritreme thickened, white, appressed to the outer one, which is moderately expanded, sinuate, reflected nearly to the plane of the aperture, much expanded and concave above and also below on the left side, wanting opposite the penult whorl; umbilicus very small, nearly concealed by the lip.

Mean divergence $33^{\circ}$; length .77 inch ; greatest breadth . 39 ; least breadth .3 inch.

35. Cyclostoma crenulosum. Shell much elongated, conic; brownish, sometimes with transwerse darker clouds and slender zigzag spots, with a band of the same around the anterior part; very coarsely striated transversely, the upper ends of the raised lines being developed into very numerous sutural crenulations, spiral lines wanting; spire with nearly rectilinear outlines; apex truncate with the loss of three whorls; five whorls remaining, with a moderately impressed suture, which is nearly concealed by the crenulations; aperture ovate-orbicular; inner peritreme orange red, on the right side coalescing with the outer peritreme, which is white, moderately expanded, sharp, concave, more produced and inflected above and at the lower end of the left side; umbilicus very small. 
Mean divergence $35^{\circ}$; length .83 inch; greatest breadth .45 inch; least breadth .35 inch.

36. Cyclostoma pauperatum. Shell very elongate and slender, conic; color - ? ; very coarsely striated transversely, not crenulated in the suture, spiral lines wanting; spire with nearly rectilinear outlines; apex truncate with the loss of three (?) whorls; five whorls remaining, with a moderately impressed suture; aperture ovate-orbicular; inner peritreme on the right side less elevated above the outer one, which is moderately expanded, concave, sharp, produced into an angle and inflected at each extremity of the left side; umbilicus very small, concealed by the lip.

Mean divergence $25^{\circ}$; length .58 inch; greatest breadth . .26 inch; least breadth .2 inch.

37. Helicina palliata. Species similar to $\boldsymbol{H}$. Brownii, Gray, but the shell is larger, thicker, less globose, with the incision as deep but much narrower and linear; the produced columella is grooved with a broad shallow furrow, while in H. Brownii it has a decply impressed line.

The characters of the incision and produced columella in this group of Helicinæ appear to be very constant. It is chiefly for this reason that $I$ regard this as a good species. The form and size are intermediate between $\boldsymbol{H}$. maxima and $\boldsymbol{H}$. Brownii.

Mean divergence $110^{\circ}$; length.43 inch; greatest breadth.69 inch; least breadth .55 inch.

35. Helicina Hollandr. Species similar to $\boldsymbol{I I}$. Brovnii, but the shell is much smaller and thinner; it is chiefly distinguished by the incision being only half as deep, and by the produced columella, which has no impressed line nor groove, although slightly raised at the margins.

Mean divergence $105^{\circ}$; length .23 inch; greatest breadth .41 inch; least breadth .32 inch.

39. Helicina macilenta. Shell rather small and thin, subdiscoidal, flattened beneath; pale brown; epidermis extremely thin, microscopically hirsute or chagrined; spire a little elevated and convex; whorls nearly fuur and one-half, scarcely convex; aperture large; labrum thin, sharp, moderately expanded and reflected, with a deep curved incision below the columella similar to that of $\boldsymbol{H}$. palliata: the produced columella is strongly margined on the inner side.

Mean divergence about $135^{\circ}$ : length .16 inch; greatest breadth . .9 inch; least breadth .23 inch.

40. Heucina albolabris. Shell with a notch like that of $I I$. maxima, but the notch is rather large proportionally; in other respects 
similar to $\boldsymbol{H}$. Brownii, but the whorls are less convex, and the last one much depressed, and the shell more solid, with a greater divergence.

Mean divergence $110^{\circ}$; length .39 inch; greatest breadth .64 inch; least breadth .5 inch.

41. Helicina citrino-labris. Shell brown or lemon yellow, very solid, outer lip very thick and always lemon yellow; in other characters like $\boldsymbol{I}$. albolabris, of which it may possibly be a variety with a greater divergence. The epidermis is very finely but not densely hirsute.

Mean divergence $123^{\circ}$; length .39 inch; greatest breadth .67 inch, least breadth .53 inch.

42. Helicina megastona. Shell globose conic, smooth and shining, rather thick, yellowish brown; spire with very convex outlines; whorls four and one-half, a little flattened; last whorl very large and high, with corresponding size of the aperture, which is quite exactly semicircular; labrum moderately reflected and thickened; columella and adjacent part of the last whorl bent into the plane of the aperture; the columella is produced into a very minute tubercle.

Mean divergence $108^{\circ}$; length .2 inch; greatest breadth .33 inch; least breadth .25 inch.

43. Helicina Josepuinz. Shell conic above, much flattened beneath, with the periphery very acute and scolloped or imbricate; above irregularly mottled with yellow, green, and white; beneath copper red, with the centre pale green; spirally ribbed above, with very fine close spiral striæ beneath; spire with the outlines concave near the apex, rectilinear in the rest; apex acute; whorls six, flat or slightly concave; aperture a spherical triangle; labrum moderately thickened and reflected, much advanced above; deposit of the base thin.

Mean divergence $100^{\circ}$; at the apex $80^{\circ}$; length .27 in 2 ; ; greatest breadth .43 inch; least breadth .36 inch.

This species belongs to Trochatella.

44. Helicina tenuis. Shell small, thin, conic, pale brown, with distant slender raised spiral lines, decussated on the spire by inequidistant lines of growth; whorls four and one-half, more inflated and subangular below the middle; aperture elliptical; labrum sharp, not reflected; labrum with a very thin deposit, columella slightly pointed.

Mean divergence $90^{\circ}$; length .08 inch; greatest breadth .09 inch; least breadth .08 inch.

This also is a Trochatella. 


\section{A TAL 0 GU E \\ O F \\ OPERCULATED LAND SHELLS WHICH INHABIT JAMAICA.}

\section{CYCLOSTORA.}

SECTION I.

1. C. pulchrum. Wood.

2. C. fimbriatulum. Sowb.

3. C. Chittyi. Ad.

4. C. aculeosum. Ad.

5. C. spinulosum. Ad.

6. C. amandum. Ad.

7. C. Hillianum, Ad.

8. C. amabile. Ad.

9. C. scabriculum.* Sowb.

10. C. lincinum. Linn.

11. C. lima. Ad.

12. C. Blandianum. Ad.

13. C. lincinellum.* Lam.

\section{SECTION II.}

14. C. variabile. Ad.

15. C. concentricum. Ad.

16. C. Grayanum.t Ad.

17. C. serriferum. Ad.

18. C. pulchrius. Ad.

19. C. articulatum. Sowb.

20. C. decussatulum. Ad.

21. C. mirandum. Ad.

22. C. moribundum. Ad.

23. C. intermedium. Ad.

24. C. monstrosum. Ad.

SECTION IIt.

25. C. Wilkinsonii. Ad.

26. C. avena. Ad.

27. C. modestum. Ad.
SECTION IV.

28. C. ambiguum. Lam.

29. C. thysanoraphe. Sowb.

30. C. pictum. Humph.

31. C. solidum. Ad.

32. C. labeo.* Lam.

33. C. Augustæ. Ad.

34. C. fascia. Gray.

35. C. proximum. Ad.

36. C. Newcombianum. Ad.

37. C. nitens, Ad.

38. C. xanthostoma, Sowb.

39. C. tenuistriatum. Ad.

40. C. ignilabre. Ad.

41. C. pisum. Ad.

\section{SECTION $\mathrm{V}$,}

(42. C. Bronnii. Ad.

43. C. fuscolineatum. Ad,

44. C. album. Lam.

(45. C. hyacinthinum. Ad.

\{46. C. Banksianum.* Sowb.

47. C. Redfieldianum. Ad.

SECTION VI.

48. C. tectilabre. Ad.

SECTION VII.

49. C. pauperatum. Ad.

50. C. crenulosum. Ad.

51. C. quinquefasciatum. Ad. 
5\%. C. Saulid. Sowl.

53. C. mordax. Ad.

54. C. maritimum. Ad.

55. C. aurora. Ad.

56. C. fecundum. Ad.

5\%. C. Adamsi. Pfr.

58. C. muticum. Ad.
59. C. armatum. Ad.

SECTION VIII.

60. C. Duffianum. Ad.

61. C. corrugatum. Sowb.

62. C. Jamaicense. Sowb.

63. C. asperulum. Sowb.

\section{EBITCINA.}

SECTION I.

64. H. palliata. Ad. 65. H. Brownii. Gray. 66. H. Hollandi. Ad. 67. II. macilenta. Ad.

\section{SECTION II.}

68. H. maxima. Sowb.

69. H. albolabris. Ad.

70. H. citrino-labris. Ad.

71. H. solitaria. Ad

72. H. affinis. $\Lambda \mathrm{d}$.

73. H. megastoma. Ad.

H. Gorese, Spr th

\section{TROCEATEIIA.}

81. T. Tankervillii. Gray.

82. T. pulchella. Gray.

83. T. Grayana.* Pfr.

84. T. Josephinæ. Ad. 85. T. tenuis. Ad.

\section{SECTION III.}

74. H. Adamsiana. Pfr.

75. H. depressa. Gray.

76. H. lineata. Ad.

\section{SECTION IV.}

77. H. neritella. Lam.

f8. H. aurantia. Gray.

79. H. Jamaicensis. Sowb.

SECTION. V.

80. H. costata. Sowb.

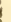

\section{IUCIDEZIA.}

86. L. aureola. Gray. 


\section{CONTRIBUTIONS TO CONCHOLOGY.}

\section{NO 2.}

Descriptions of smpposel new species and rarieties of IIExicidae from Jamaica, by C. B. Arams, Professor Ec. in Amherst Collegre, Massachusetts. Oct. 1849.

Geomeraxia. Pfr. To the single species which Dr. Pfeiffer math: the troc of this new genus, we have the pleasure of arting two or three, all of which are of much less size. 'They have the same gen-

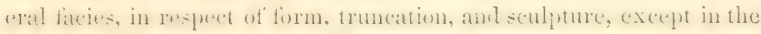
spiral striæ of $G$.elegans, as well as the most essential generic characters of $G$. Jamaicensis, Pfr. None of the new species however exeeed Dr. Pteiller's species in the derelopment of the gencric characters, and his species remains therefore the most appropriate type, as which its superior size gires it a practical advantage.

It is a matter of profound regret, that the question of the existence of an operculum is not yet definitively settled. Of $G$. minor a multitude of individuals were seen in varicus stages of decaly and many in a fresh state, but without the animal. No operculum was seen in any specimens, nor were there occuring loose with the shells any opercula, which could have belonged to them. So far as an opinion can

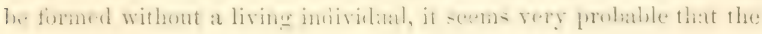
genus is not opereulated. Indeed its aflinites with Cylindrella are such, that we were at first lisposed to regard these shells as an aberrant group of that genus. They resemble it in the great degree of truncation, in the general form, in the somptore, and eren in the ap)erture, for some Cylindella are slightly effires. It is mot to be forgotten however, that the shells of (iemelamiat also checly resemble those of 'Truneatella. But the inland habits of the species rember it rery grobable that the animals have little athinity with a maritime gemus.

Since this genus is little kumwn, we commonere with a deseription of the typical species, frem a sereimen in the Cumingian Collection, for the loan of which and of sereral wher rare or mique slecimens of 
Jamaica land shells, I hare been indebted to the liberality of Mr. Cuming.

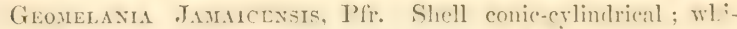
tish; densely sculptured with strong tran-verset somen hat angular ribs, which become obsolete only on the anterior extrenity of the last whorl ; spire with rectilinear outlines; apex truncate with the loss of - - whorls; nearly seven whorls remaining, rather convex, with a well impressed suture; aperture ovate, widely and deeply efluse; labrum much thickened, reflected, very much produced in the lower part; labium rather thick, separated by a slight groove from the penultimate whorl, separated above from the labrum by a small sinus.

Mean divergence $16^{\circ}$; length .66 inch; greatest breadth .2 inch; least breadth .16 inch.

Geomelania minor. This may be only a variety of the preceding, but the dimensions given below are those of the largest, among several hundreds, which we have seen. The most essential difference is in the aperture, which is but slightly effuse; the labrum is throughout much expanded convexly, and is by no means so disproportionately producel in the lower part. The apex is truncate with the loss of 6 or 7 wherls.

Mean divergence $14^{\circ}$ to $15^{\circ}$; length .41 inch ; greatest breadth .13 inch; least breadth .14 inch.

Geonelania expansa. Shell much elongate, conic; whitish; rather densely sculptured with strong transverse somewhat areuate ribs, which are flattened on the forward side, are less regular than in G. minor, and are obsolete on the anterior half of the last whorl; spire with rectilinear outlines; apex truncate with the loss of whorls; nearly seven whorls remaining, molerately convex, with a well impressed suture; aperture ovate, much expranted laterally, widely and rather decply effuse anteriorly ; labrum but little thickened, slightly reflected above, more reflected and widely spreasl below; labium rather thin, a little reflected into the concavity of the central region of the penult whorl, to which it is appressed.

Mean divergence $18^{\circ}$; length 53 inch; greatest breadth .185 inch; least breadth .15 inch.

Geomelaxia elegans. Shell cylindrical; whitish; elegantly

* In these papers the word transverse is used in reference to the direction of growth, in distinction from spical, and of course withotii any reference to the axis 'the shell. 
sculptured with distant prominent very slender ribs, which are not impressed by the very numerous microscopic spiral stria, of which about twenty are visible on the whorls of the spire: spire with nearly rectilinear outlines; apex truncate with the loss of — whorls; seven whorls remaining, quite convex, with a very deep suture; aperture ovate, moderately effuse; labrum moderately thickened and reflected, and but little produced at the lower part; labium prominent, rather thick, slightly detached from the penult whorl at the very small sinus above which it unites with the labrum.

Mean divergence $13^{\circ}$ to $14^{\circ}$; length .3 inch; greatest breadth .08 inch; least breadth .07 inch.

Crundrella Beardengaya. Shell quite regularly conic, but much elongated ; whitish; with closely set small obtuse ribs which are not oblique, not carinated anteriorly ; spire with rectilinear outlines; apex truncate with the loss of six whorls; eight whorls remaining, quite convex, with a deep suture; last whorl a little detached, angular above; lip sharp, reflected opposite to the penult whorl, otherwise scarcely reflected.

Length .3 inch; breadth .07 inch.

C. pgymaea Ad. Jan. 1. 1845, is similar, but its aperture is wider, the whorls more convex with a deeper suture, and the shell is much smaller.

Cylindrelda Arimestand. Shell sinistrorsal, very long, cylindrical in the lower two-thirds, moderately tapering above; white; with very oblique very closely set fine rather sharp strie which are more oblique in their upper part, -anteriorly with an extremely prominent and acute carina, on the left side of the last whorl with a carina scarcely less prominent and acute, on the upper side with a third carina quite acute and prominent, on the right side subangular; spire with outlines mostly reetilinear, with a waved axis at the tip ; apex broadly truneate with the loss of twelve whorls; eighteen to twenty-two whorls remaining, the usual total number being thirty; (a short entire specimen has twenty-eight;) whorls flattened or scarcely convex, with a moderatcly impressed suture; last whorl very much produced obliquely; aperture angulated in proportion to the sharpness of the carinae, trapezoidal, the upper left side being the longer; with one diameter parallel and the other nearly perpendicu- 
lar to the axis of the shell; tip reflected nearly into the plane of the aperture sharp, rather wide.

Common full size, 1.45 inch long, .17 inch wile: of a large sicll, length 1.fis inch; lueadth .17.5 inch; of a suall shell, length 1.07 inch; breadth .16 inch : of a small entire shell, length 1.65.

This species probably excels all other shells in the number of whorls.

Cruindrella alba. Shell subfusiform, widest above the middle; pure white; stria scarcely visible umler a common magnitier exerpt on the last two whorls; the last whorl is sharply carinate anteriorly, rather obtusely carinate just alowe the middle; spire with rectilinear out nes; apex truncate with the loss of thirteen or fourteen whorls, the upper part of the spire before truncation being very long and slender; thirteen or fourteen whorls remaining, slightly conrex, with a well impressed suture: last whorl much produced ohliquely; aperture sharply angular anteriorly. ohtusely so on the right, in the rest well rounded; lip moderately thickened, reflected nearly into the plane of the aperture, shining, sharp, rather narrow.

Length .4 inch; breadth .083 inch.

Var. striatula; striæ very distinct under a common magnifier; length .52 inch; breadth. 11 inch.

Crlixprella costulata. Shell subovate, but elongated; whitish; with thin very prominent very tistant molerately oblique rihs, of which there are about ten on the penult whorl, and which, as usual in this genus, are more crowded on the last whorl,-anteriorly with a prominent but not shap carina ; spire with convex outlines along the middle; apex truncate with the loss of five or six whorls; nine or ten whorls remaining, rather flattenerl, but with a deep suture; last whorl much detarthed and produced angulaterl on the right : aperture mueh dilated on the right, anteriorly a little angular, the rest rounded; lip, somes what thickenet, rather narrow and sharp, reflected into the plane of the aperture.

I.ngth .2.5 inch; breadih .075 incle; length of an entire specimen .325 inch.

Crlindrella moxtana. Shell subeylindrical, tapering above; pale renl, rancly white; with elosely set extremely fine ohlique strix, which are most arcuate abore the middle, with a rery small rather prominent carina anteriorly, slightly angulated just abowe the mithlle of the lat wherl: fire with enrex ontlines in the upper third, in the rest rectilinear, ahove the place of truncation rectilinear up to 
the third and fourth whorls, and there slightly concave ; apex broatly truncate with the loss of ten or eleven whorls; nine or ten remaining, scarcely convex, with a lightly impressed slightly marginate suture; last whorl produced perpendicularly to the axis of the spire; aperture a little dilated on the right, otherwise orbicular, a littlespreading; lijs well reflected only at the extreme margin.

Length .58 inch; breadth .163. inch.

Crmindrella Gravesir. Shell ovate-cylindrical moderately elongated, with the last whorl a little quarlrangular; white; with very dense very tine slighty arcuate very oblique striac, with the arinae of the last whorl obsolete; spire with rather convex outlines; apex truncate with the loss of __ whorls; nine to eleven whorls remaining, scarcely convex, with a lightly imprested margined suture; last whorl moderately protueed at right angles to the axis of the spire; aperture somewhat quadrangular, lip rather wide, reflected into the plane of the aperture.

Var. $a$, with a small prominent anterior carina.

Dimensions rather variable, as follows in three individuals hefore me. No. 1 ; length .72 inch; breadth.17s inch. No 2 ; length .66 inch; breadth .2 inch. No. 3 ; length .55 inch; breadth .19 inch.

Cremprelda amigrat differs from C. rosea, P'fr., in having the outlines more convex, the whorls very deep. If not a monstrosity, it is probably a gool species; but fiom a single specimen I am unable to decide.

Cylintrella rosea, Pfr. var. magna, Ad. Length 1 ineh; breadth .34 inch.

Cylindrella rosea. Pfr. var. mijor, Ad. Length 1.3 inch; breadth .45 inch.

The dimensions of the type are the following: length .73 inch; breadth .26 inch.

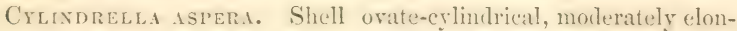
gated ; red mostly, with white anteriorly, or sometimes white in half of the shell; with very coarse olligme stria, which are most areuate at or below the midtle, with the intervening raised lines acute-edged, with a nearly obsolete carina anteriorly, and another more prominent midway between this and the mislle of the last whorl; spire with quite convex outlines; apex truncate with the loss of — whorls; nine or ten whorls rematining, quite consex, with a well impressed $\leq n-$ ture; last whorl moderately produced, sul,augular on the right side; aperture large, spreading, subrectilinear above, in the rest orbicular, 
slightly effuse anteriorly; lip rather wide, not very sharp, reflected nearly into the plane of the aperture.

Length .94 inch; breadth .3 inch.

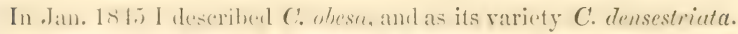

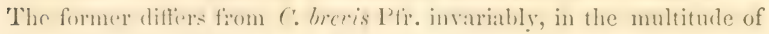
indiviluals which I hate seren, in laving the raised lines complatively very distant. It is limited to a small district, on both sides of which C. brevis is widely distributed. If not a good species, it may retain the name, C. obesa, as a variety. But C. densestriata is specifically illentical with C. brevis, yet it is not an inappropriate name for a very shining variety in which the stria are excessively fine.

Crlindrella columa is perhaps a variety of $C$. brevis Pfr. But the spire has rectilinear and almost exactly parallel outlines in its lower two-thirds or three-fourths; the shell is longer; the whorls are wholly flattened; the lip is more willely spread; and the stria are as small as in the more finely striated varieties of $\mathrm{C}$. brevis.

Length .72 inch; breatth .2.2 inch; of another, length 575 inch; breadth .18 inch.

Variety INTERMEDIA more resembles C. brevis in having the whorls a little convex; but the shell is longer than the type of C. columna, and the aperture a little larger.

Length . 78 inch; breadth .22 inch.

C. roseu, Arl. Proe. Bost. Soc. Nit. Mist. Fel). 18, 18.6, receired the name of C. Carxen in my printed catalcgue of shells Jan. 1, 1847.

C. carnea var. cerina differs from the type chiefly in its wax color and in being a little more slender.

Cimindela norita. Shell subovate or fusiform, but elongated ; whitish; with fue oblique arcuate sharp prominent but not very rosely set raised lines, anteriorly with two carinae which are not prominent; spire with the outlines moderately convex in the midlle and lower whorls; apex truncate with the loss of —— whorls; eight or nine whorls remaining, chute convex, with a deep suture; last whorl well detached and produed; aperture sulangular on the right side, in the rest rounded; lip a little thickened, narrow, moderately reflected.

Length . 38 inch; breadth .11 inch.

Crlixdrelia simplex. Shell suborate, or fusiform, moderately elongated; whitish; with very oblique straight fiunt straie, with one moderately sharp carina at the anterior extre!nity, and another which 
is slight and obtuse a little above the midlle of the last whorl; spire with the outlines quite convex throughent most of the shell; apex truncate with the loss of whorls; ten and one-half whorls remaining, quite convex, with a deep suture; last whorl slightly produecel ; apresture angular at the anterior extremity and on the millle of the right -ible; lip thin, sharp, narrow, and moderately reflecterl.

Length .315 inch; breadth .1 inch.

Crlindrella Hrdeana. Syn. Bulimus Gossei, Pfr. If this species be removed tiom Ibulimus to Cylimledlat, it will requiro a new name. It appears to belomg to J)r. I'feiller's section fiof C'ylindreilla with a persistent aprex, and stomerly resemhles soveral of the sjecies of that section in its anderal form, and in the position am form of the aperture. It has the type of sculpture usual in Cylindrella, and like most of this genus, but unlike any species of Bulimus, in Jamacia, it occurs in great profusion among limestone rocks. It is most closely allied to C. pontifica, Grould, Mss.

C. cylindrus, Ad. Proc. Bost. Soc. Nat. Hist. Jan. 1849, received the name of C. RuBkA in my printed Catologue of shells Jan. 1847.

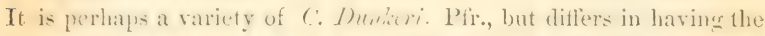
erreate-t diamefer at or ahore the midhle of the shell, while in the latter it is in the lower thirl, above which the shell tapers regularly, C. rubra is larger, has coarser strix, and is always deep red. C. Dunkeri is always brown. The last luses eight or nine whorls by truncation, and has twelve remaining.

Crumdrella smilis is perhaps another rariety of C. Dunkeri, P'r. but is much smaller. hats the aperture lass angulated antrerorly,

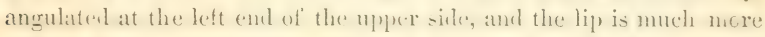
arched ature: the striation is finer in propution to the size: nine or ten whorls are lost by truncation, and twelve remain.

Length .475 inch; breadth .09 inch.

Crumdrelda tenella is much more slender than C. Dunkeri, has thirtern whonls, and the sriation is microsonpically minute: the aperture is like that of C. I) monkeri, anel, like ( . rubra, it tapers from above the middle down to the anterior extremity.

Length .5 inch breadth .077 inch.

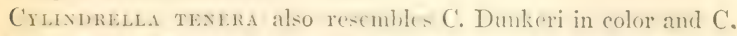
rubra in form. It is very small, las the aperture orbicular, and the striation microscopic; it loses six whorls by truncation, and has ten remaining.

Length .28 inch; breadth .055 inch. 
Synopsis of classification of species and varicties of Cylindrella inhabiting Jamaica.

The scheme is modified from Dr. Pfeiffer's.

$$
\begin{aligned}
& \text { Geomelaniform ; 5-6.* } \\
& \text { Clausiliaeform ; 7-18; } \\
& \text { sinistrorsal ; 7-9; } \\
& \text { dextrorsal ; } 10-18 \text {; } \\
& \text { smooth } 10 ; \\
& \text { costulate ; } 11-12 \text {; } \\
& \text { striate ; } 13-18 . \\
& \text { Pupaeform ; 19-29; }
\end{aligned}
$$

aperture produced, cylindrical ; 19-22 ;

$$
\text { " } \quad \text { " spreading; 23-26; }
$$

aperture not produced; $27-29$.

Fusiform ; 30—32 ;

polished; 30 ;

not polished; $31-32$.

Bulimiform; 33.

Columnar ; $34-38$.

Achitina proceri. Shell conic, much elongated; white, more or less tinged with brown, with rather broad dark brown somewhat oblique stripes, which are waved on the posterior margin, interrupted at the mirdle of the last whorl, and of which there are four or five on each whorl, except on the first three or four which are colorless; varicose eoincidently with the brown stripes on the last whorl, like A. leucozmias with closely set very coarse transcerse stria or ribs; spire with the outlines nearly rectilinear; apex rather ohtuse; whorls about ten, rather convex, with a slightly channeled suture; aperture rather narrow, quite acute above; labrum rather sharp, produced to an extraordinary degree in the middle, and then abruptly retreating in a deep well rounded sinus, which reaches to the twisted and much arcuated columella.

Mean divergence $27^{\circ}$; length 1.87 .5 inch ; breatth 4 inch : length of aperture .52 inch. Of another individual, mean divergence :3 $1^{\sim}$; length 1.08 inch; breadth .395 inch; length of aperture .44 inch.

* These numbers refer to a catalogue of the Jamaice. Inclieidac, which will fullow the descriptions of specics. 


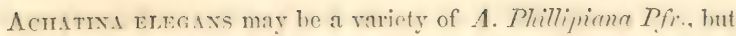
it has the stria extremely fine, and the diark hrown stripes are much narrower. Dr. P'feifter's species hat the strice very coarse and the stripes very wide.

Acmotiva xameraxis. Shell sulfusiform; pale brown or pale reddish brown, with dark bown transverse stripes, which are not very wille, reaching nearly to the anterior extremity, alsout four on each whorl except on the first three, which have none; with very dense rather small strix; spire with the outlines quite convex; whorls eight, molerately conrex, with a well impresserl suture; aperture long, narrow in the upper half, and very acute above; labrum sharp, produeed atong the milithe, a little angulated below the mistlle; columella nearly straight, rather slender, and pointed.

Mean divergence 310 ; length . .3 inch; breadth. 25 inch; length of aperture .35 inch.

Var. $a$, with very few brown stripes.

Achativa lifita. Sleell elongate, subconic, with a liroad deep constriction around the midhle of the last whorl; pale brown, with dark brown narrow transterse stripes, which are sometimes nearly obsulete, of which there are alont three on each whorl, except on the first three or four, which have none; raricate at the last one or two brown stripes, with rather fine crowed transverse stria ; spire with the ontlines moderately convex : apex small; whorls ahout seven and one latelf, al little convex, with a well impresset suture; aperture long, much motified hy the intrusion of the latsum at the eon-trietion of the last whorl; lalsum thiekened at the econstriction ; eolumellat a little twisted and arcuated.

Me:m divergenee $2 . f^{0}$; length . wis inch; breadth .195 inch; length of aperture .26 inch.

Acmatina angrostoma. Shell fusiform; pale reddish, with transwerse rather martow datk hown siripes, of which there are about four on each whorl except on the first three; with extremely fine crowded transverse strix; spire with moderately convex outlines; apex rather smatl; wherls scren, moleratcly convex, with at well impressed suture; aperture very long and narrow; labrum very thin and sharp; columnella produced to an extmordinary degree, straight, a little twisted.

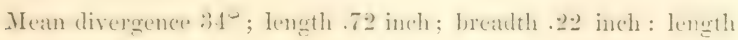
of aperture .36 inch.

Acmatsa Ixgaldesaxa. Shell fuiturm: pale brownish, with but 
four or five dark brown transverse stripes; with very minnte rather numerous but not crowded transverse stria'; spire with morterately convex outlines; apex rather small ; whorls seven, mouleratuly consex, with a well impresed fincly corded suture; aperture very long, rather narrow; lip, thin, with the cutge sharp and curved forwarls; columella moderately produced and arcuate.

Mean divergence $36^{\circ}$; length .75 inch; breatth .25 inch; length of aperture .35 inch.

Acmativa entcolor. Sprecies similar to the preceeding. lut the shell is uniformly light brown, without any dark stripes: the strix are rather more strongly impresed ; the columella is not areuate; and the form is rather more slender.

Mean divergence $3: 3^{\circ}$; length . 7 inch; breatth .21 inch; length of aperture .33 inch.

Acinatixa levis. Shell much elongated, conic; very pale bromn, shining; very thin, smooth, with microscopic transverse stria, which are quite numerons on the upper whorls; spire with rectilinear outlines; apex not very small; whorls seren, a little convex, with a moderately impresed suture; aperture orate, acute above; latrum thin and sharp; columella slightly arcuate.

Mean diverence $14^{\circ}$ or $15^{\circ}$; length .12 inch; brendth .1 inch; length of aperture .13 inch.

This may be a raricty of $A$. pelluecens; but that shell has more numerons strie, a constant difference in the inclividuals which I latve seen.

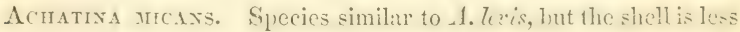
elongated, the ontlines of the spire are more convex, the aperture is shorter, and the columella is more twisted and not areuate.

Mean divergence $17^{\circ}$; length .41 inch; breadth .11.) inch; length of aperture .12 inch.

Achatina striosa. Shell elongated, conic; white, with a horn

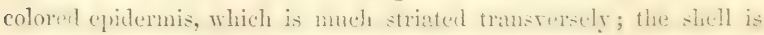
smooth; spire with nearly rectilinear outlines; apex not rery small; whorls eight, short, modrately convex, whih a derep suture: anertme short, ovate, moderately acute above; labrum thin, sharp, not produced along the middle; columella shoit, brotully truncated, much arenated.

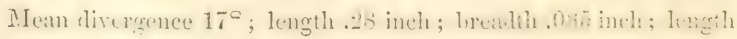
of aperture .08 .

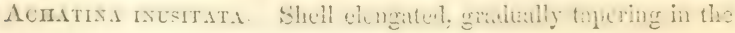


upper half, cylintrieal in the lower half, wide and blunt anterioriy, with a broat very deep eonst:iction about the midlle of the last whorl; dingy white; with very distant lamelliform transverse ribs, about ten on each whorl, with strong irregular intervening stria; spire with eonrex outlines; apr.x small; whorls nine, very convex, with a deeply impressed, and near the apex a chanclled, suture; last whorl small and very slort ; aperture ovate, acute abore, much morlified by the constrietion of the last wherl, which eonstriction bents the sharp latrum into two large ares of small cireles; columella remarkably twisted and arcuate.

Length .16 inch; brealth .0.) inch; length of aperture .0:3:? inch.

This speeies approaches Cylindrella in general form, (so as to render useless the character of dirergenen, ) and resembles $C$. costulutu in sculpture.

Brtruts. The first two or three following epecies with some describer aliore belong to a group of small shells, which are intermediate between Bulimus and Achatina. Thuse which approxinate most to Achatina have been referred to that gemus, and the following two or three conform more to the type of Bulimus. Among these shells, the distinction between these two genera loses its value.

Mr. Reere has deceribed a species of this group, of which some indiriduals have, and some have not a truncated columella.

Befinus nitidusculus. Shell long ovate conic; dingy white; smooth and shining. with a few rery distant exer-sisely miante transverse strix; spire with nearly rectilinear outlines; apex rather obtuse: whorls marly six, ratheremex, with a well impressed suture la-t whorl leng; a perture long orate, guite acute above; labrum very thin and sharp; columella somewhat twisted.

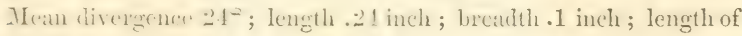
aperture .1 inch.

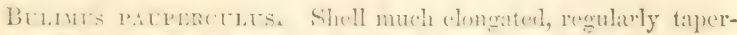
ing to the summit; white, with at thin lum colored epidernis; with numerous broul lightly impressed anduate transvers strie ; spire with

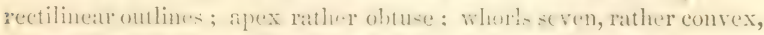
with a well impreserl sutur"; aprerture long orate, quite ateute above; labrum thin and sharp; colımella well thickened.

Alean diverwones $18^{2}$; length 2.2 inch; brealth .2.5 inch; length of aperture .075 inch. 
Belmus tererela. Shell very much elongated, regularly tapering to the summit; dingy white; with numerous transwerse lightly impressed strie; spire with rectilinear ontlines; apex rather obtuse; whorls nine and one-half, short, quite convex, with a deep suture; aperture subovate, moderately acute above; labrum thin and sharp.

Mean divergence $12^{\circ}$; length . . inch; breadth .07 inch; length of aperture .052 inch.

Belues axomales. Shell with the general form and seulpture of Truncatella, cylindrical ; whitish ; with very numerous strongr transverse ribs, which are continuch quite into the suture; spire with rectilinear outlines; apex — ? ( the apex in the only specimen before me is broidly truncate, ) six whorls remaining, which are moterately convex, somewhat shouklered, with a well impressed suture; latst whorl rather long, with a slight constriction around the middle, which also modifies the aperture, which is rather long, slightly acute above, well rounded below; labrum thin and sharp; columella stout, very prominent, areuated or twisted in a loose spiral to an extraordinary degree.

Mean divergence $12^{\circ}$; length .23 inch; breadth .075 inch; length of aperture .07 inch.

Bu liuts manus. Shell rery much elongated, cylindrical; translucent, white; elegantly sculptured with very numerous flat slightly prominent areuate ribs, about twenty-five on each whorl, ___ and numerous microscopic spiral strie; spire with rectilinear ontlines; apex very obtuse; whorls seven, long, very convex, with a very deep suture; last whorl very long and narrow; aperture short, molerately acute above, well rounded below; labrum sharp; columella not perceptibly thickened.

Mean divergence $8^{\circ}$ or $9^{\circ}$; length .1 inch; breadth .026 inch; length of aperture .024 inch.

Belmus MoNodon. Shell orate-conic; dingy white; with some slight strie of growth; spire with the ontlines somewhat convex; apex subacute; whorls nearly five ant one-half, a little convex and shouldercul, with at well impressed suture; list whorl larese and wille, sometimes a little constricted near the aperture, whele is rather wide orate, molerately arute ahove; lahrum thin and shamp: columella straight, with an oblique tooth near its extremity; umbilicus very small.

Mean divergence $45^{\circ}$; length .25 inch; breadth .15 inch; length of aperture 13 inch. 
Burmos miramers. Shell ratlier long and conic, with twothirds of each whorl enormously inflated, gradually more ahruptly with the progress of growth, so as to give to the shell the firm of at screw; subtransparent, whitish; with numerous miscroscopic spiral stria, and very distant transwerse erect lamellar ribs, which have smooth rounded edges, and are most elevated at the summit of the convexity of the whorls, and diminish much over the anterior extremity of the shell; spire with rather convex outlines ; apex with the inflation proportionally much longer and the rils lut slightly elevated; whorls about seven, with an indistinct suture; aprerture modified by the form of the last whorl at its termination, and by the remarkably prominent and much twisted columella, nearly into the form of the figure 8 .

Length . 1 inch; breadth .062 inch.

This most extraordinary of all the land shells which I have seen, strikes the beholder with amazement, and its novelty remlexs description difficult.

IIELix Patixa may be a rariety of $I I$. acutisime, Lam., but it is concare on both siles of the periphery, like II. soror, while Latmarck's shell is always convex below and usually also alove the preriphery: the surface of II. patina is smooth throushout, execpt a slight granulation near the end of the last whorl, and is rather irregularly impressed with seattered lines, which are mostly perpendicular to the striæ of growth.

(ireatest brealth g.2) inches: least brealth 2 inches: height 1 inch.

Helix rluctuata resembles the preceding, but the surface is more uniformly and regularly granulated even than in II. acutissima: the outline of the last whorl is an oval consilemally elongated ; on the first half of this whorl, the shell is concare on beth siles of the periphery, which next rather suddenly becomes obtuse: the lower side is very convex through the central regien, and the upper surtites is obliquely waved or wrinkled.

Greatest breadth 2.2 inches; least breadth 1.7 inch; height 1 inch.*

Hetix cara. Shell convex abore, more convex beneath, with a

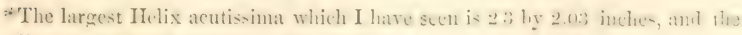
smallest mature individual is $1.1 \mathrm{by} .95$ inch. 
rery acute periphery; brown, with a white lip); surface smonth, or almost microseopically gramulated and punctulated, with a smooth shining ophlormis; spire moderately and some-what eonvesly relevalted; whorls fine, scarcely convex, with a suture not impressed; aperture subtriangular, with a rery thick, strong lip, which hats alomg

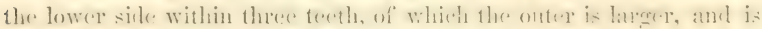
doulle at the extremity when mature, or mearly to the hase when first formed; the inner tooth is small and very near the columella; the two outer teeth have exterion pits poprortionate to their size; umbilicus small, entirely concealed in the old shells.

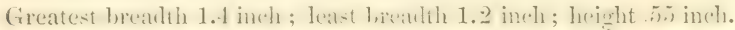

Helix Cimitryana. Shell convex above, more convex beneath and more witely at than the precenting, next to the ante priphery a little concave above and very convex below; brownish white, with a zone of deep brown on both sides of the whitish periphery, with a brown lip; surface sliphty striaterl, lhining, with a smocth shining lorwn equitemis, which is theciluens in narrow jrrecularly zigzag portions; spire convex, moderately elevated; whorls four and onehalf, nearly flat, with a suture not impressesl; aperture subtriangular but much modified hy the enwexity of the list whorl, with four teeth, of which the outer two stand orer one exterior pit, and of which the inner ons is small, very near the coltumella, and without any exterior pit.

Greatest breadth 1 inch; least breadth .95 inch; height 5 inch.

Helix picturata. Species like H. sinuata, Müll., but the shell is usually smaller, the wherls are always much slorter, tlir spire more depressed, and the shell less convex beneath: it is remarkable for

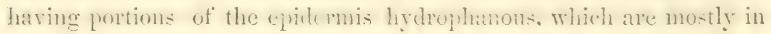
zigzag or ralliating pale brown stripes : the aperture is much more expander laterally than II. sinuata: umbilicus small, partly covered by the reflected lip.

(ireatest breadth .9 inch; least breath . 7 : inch: heirht . 98 inch. Varicty $a$, without umbilicus and the spire rather more elerated.

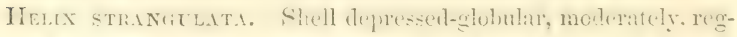

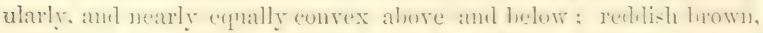

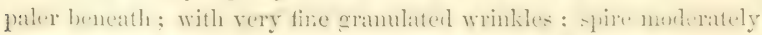
convex, with a rather deep suture, last whorl rery high; aperture

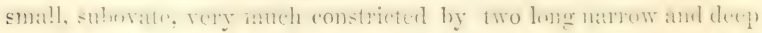

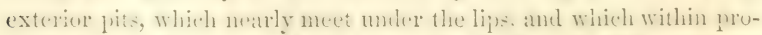
ject ats two teeth connected at base, ats in II. Lronnie, P'fi., but are 
not parallel ; next is a larece tooth, which truminates at the onter malgin of the lip, and next a fourth on the collumella, which enters a

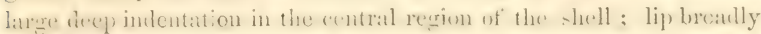

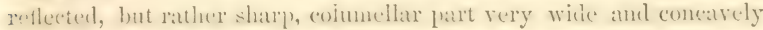
flattened; umbilicus wanting.

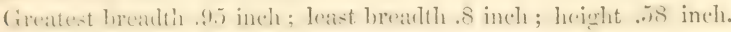

Helix torrefact. Shell conoid, with a very thin transparent epithermis, on the mpuer whork, which is at litle thicker and strawcolored on the lower whorls; smooth or with almost imperceptible strix of growth; spire like that of $I I$. Cooliana, Fer., but a little more elevated; whorls eight, short, moderately convex, with a well impressed suture; last whorl with the base, (intermediate between

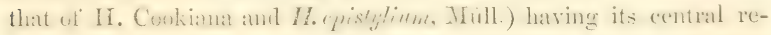
grion rather deeply hut not very videly indenterl; aperture lunate;

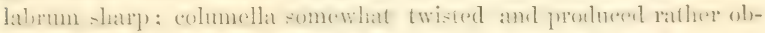
linfuely; aroume the base of the last whorl within is a lamellat, which slopes inwardly as it rises.

Dimensions of two varicties: No. 1: greatest breadth .7 inch; least breadth .63 inch; height .7 inch. No. 2 : greatest breadth .6 inch; least breadth . 55 inch; height .7 inch.

Hextx epistrlidum. Shell conoid; white; with microscopic strie of growth: spire with rery conver ontlines; apex rery ohtuse ; whorls six and onc-lialf, a litule comvex, with a well impresecelsuture; last whom with a subamerular periplery ; aperture lunate, wiblout

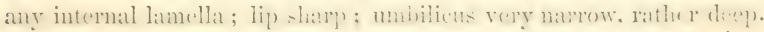

Greatest breadth .175 inclı; least breadth .16 inch; height .17 inch.

Exeept in its mimute size this species moch resembles II. "uistylium, and still more closely H. Cookiana.

Herrx pILs. Shell very globular; white, translucent; with ex-

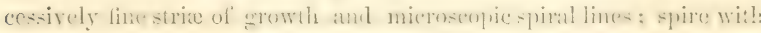
very convex outlines; apex very obtuse; whorls more than six, quite convex, with a well impressed suture; aperture lunate, except as

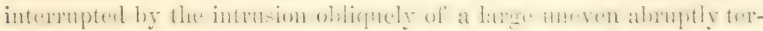
minating columella; lip very thin and sharp; within, nearly half way up the outer side, is a high lamella, which after entering half

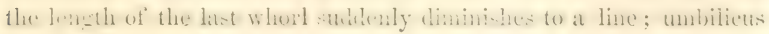
wanting."

Greatest breadth .6 inch; height .53 inch.

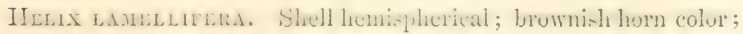


plichrmis with slarp but microscopic projecting lamelliform points, whith are frefuntuty worn ofl; with rather coarse and distant strice of growth; spire convex, molerately elevated ; apex subacute; whorl. five amd ont-half, a litth. convex, with a well impressed suture; aperture Inn:te: on the insicle: of the periphery of the last whorl, a little within the lathrum, commonees a slightly elcvated lamella, which exteruls from $100^{\circ}$ to $120^{\circ}$ firther in ; labrum very thin and slarp; columella somewhat thickened, very oblique; columellar region moderately irdented.

(ireatest bueatth . .99) inch; least brealth .8.) inch; height .27 inch.

Helix graninicola. Shell depressed globular; brown, with a white zone next below the sutme, and another on the periphery of the last whorl, which last zone is margined above with a blackish brown zone: with strix of growth which are fine beneath and coarse ahove; spire convex, morlerately elevated; apex rather obtuse: whorls more than five, rather convex, with a well impressed suture; aperture more than a semicircle, much modified by the penult whorl; litbrum rather sharp and thin; thickened a little within by a purple deposit, slightly reflected orer the small umbilicus.

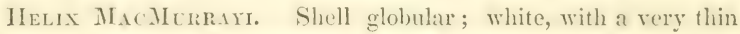
brown epidermis; with very fine striae of growth, and rery lightly impressed unequal spiral lines; spire with the ontlines quite convex; apex very obtuse; whorls nearly six, quite convex, a little concave at the uyper part, with a lightly impresect suture; aperture suborbicular, a little modified by the intrusion of the last whorl; labrum not reflected, rather slarp, but in the old shells not thin; umbilicus wanting.

fircatest breadth 1.9 inch ; least brealth 1.6 inch; height 1.5 inch.

Hedx mexia. Shell depressed globular; with a rather thick chidermis, which is horn colored on the upper whorls, and greenish brown on the rest; with excesively fine striae of growth: spire convex, moleritely elevated ; apex very obtuse; whorls fine, moderately convex, with a well impressed suture; last whorl large, somewhat depressed ; aperture suborbicular, angular at the end of the oblique white columella, and molified considerably by the penult whorl; lip excessively thin and sharp; umbilicus wanting.

This shell resembles the youmg of the preceding, which when young is much flattened on the spire, has the aperture much larger, and the columella is straight.

Greatest breadth .6 inch; least breadth .5 inch; height .4 inch. 


\title{
OONTRTBETTIONS TO OONCHOLOGY.
}

\author{
No. :3.

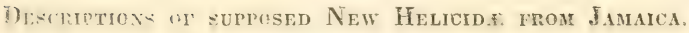

Continued from p. 32.

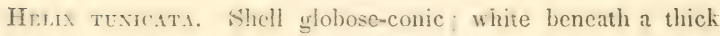
pidermis, which is yellowish brown on the spire, and dark brown son the last whorl, anci peels off in flakes in the early stages of decay; with fine strix of growth and very lightly impressed spiral lines; spire conic, well elevated, with the outlines a little convex; apex acute; whorls fire and onc-half, rather convex, with a well impressed suture; aperture subquitrate, with the outer angle rounded off; labrum thin and sharp: columella pure white, dilated, somewhat spiral; umbilicus none.

Mean divergence $110^{\circ}$; greatest breadih 1.05 inch; least breadth .85 inch; height 1 inch.

This species difiers from II. munda in the conical and more elevated spire, greater size, stouter and subspiral columella, \&c.

Inlix stlphere.1. Shell sub-globose, conic above, and a little rapering below; yellow, nearly transparent; smooth and shining; spire with the outlines a little convex, well elevated, conic; apex very small and acute; whorls four, a little convex, with a well impressed finely margined suture; last whorl very long; aperture subsubovate; labrum very thin and sharp; columella much produced, nearly straight; umbilicus none.

Mean divergence $90^{\circ}$; greatest breadth .175 inch; least breadth .13 inch; height .16 inch.

Perhips this is a young shell, but probably not of any described species.

Helix virginea. Shell conic; pale brown, with the upper whorls and a zone on the periphery horn colored, with narrow portion: of epidermis scattered somewhat in zigzag, which are white 


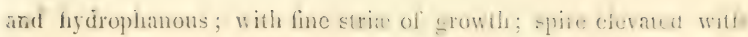
the outlines alunost rectilinear ; aftex rather obtuse; whols nearly

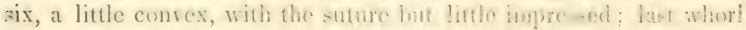

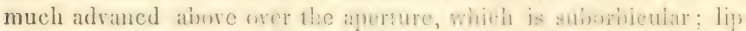

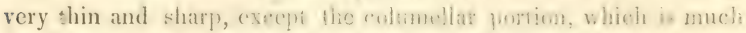

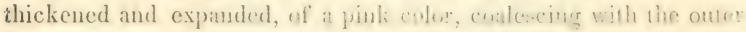
lip in a curve; umbilicus wanting.

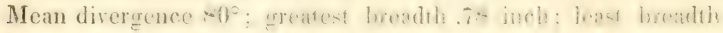
.67 inch; height .73 inch.

Hemix fuscocrncta. Shell conic; white beneath a very thick epidermis, which has a narrow well defined blackish zone next below the suture, and nox! holow is pale brown, gratunlly becoming

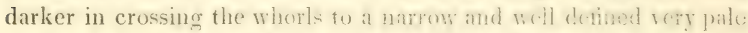
yellowish brown zone, whirh rum new aime the surue and along the periphery of the last whorl, the base of which is wholly of a dark

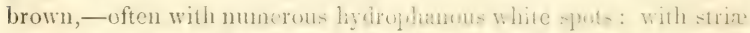

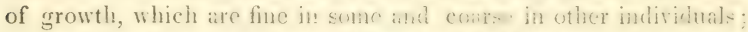

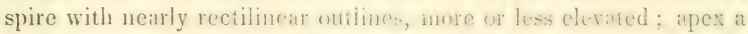
little obtuse; whorls six, a lithle comes, wh a well imprened suture : aperture somewhat depresed orbicular: liy rather thin and sharp,

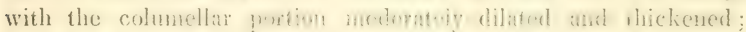
umbilicus wanting.

The proportions are quite rariable, as in the four following examples, the first being a young shell.

No. 1. Mean divergence $70^{\circ}$; greatest breadth .6 inch; least breadth .52 inch; height .65 inch.

No. 2. Mean divergence $82^{\circ}$; wreatest breadth .83 inch; least breadth .7 inch; height .79 inch.

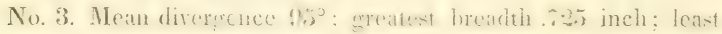
breadth .58 inch; height .57 inch.

No. 4. Mean diserence $146^{2}$; Greatrat breadh . \&1 inch: leas breadth .63 inch; height .57 inch.

Heurx smuds. Species similar to $I T$. arboreoides $\Lambda d$; but the shell is larger, the whorls are much higher, and there is an umbilicus about .04 inch in diameter extending through to the anex. The young of $\boldsymbol{I}$. r ristylimm Mull, also resemble this specius, but have no umbilicus, a much more cumven lmes, and an anmular beriphery. while the periphery of this is very broadly rounded.

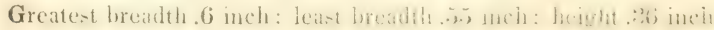

IIcux Iloulaxd. Species similar to $I I$. arborcoides Ad.: but 
The whorls are lower: Uhere is an 1 mblilens about .0:3 inch in damm ser extending to the apes; the anderture is smaller, and the last whorl is much flattened beneath.

Greatest breatih .19) inch; leatst brazdh .4:3 inch; height .25 inch.

II:mx Ambuti. A smole imlividual occurs, which is like $\boldsymbol{H}$. similis, but simaller: whith the spire more elevated, the columella less chligue, and the anterion part of the lip more directly transverse, with a smaller umbilicus. The suture is deeper than in II. similis or in MY. arburablen, between which this slıcll is in most characters intermediate. Having but one specimen, I do not regard the species as fully established.

Greates loreuhis . 16 inch; least breathin .12 inch; height .25 inch.

Helix Antuonians. Shell conic; whitish; with a thin pale brown epidermis; with exessindy the stric of growth; spire with rather conves oathines, well clemated ; apex subacute; whorls seven, (fuite comvex, with a deep sature; aperture sublunate; lip sharp, a little reflected in the columellar portion; umbilicus narrow.

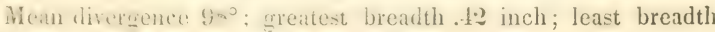
.375 inch; height .35 inch.

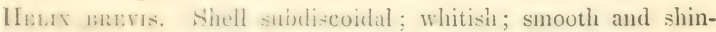
inir; spire cumven, but litie elevated; apex obtuse; whorls more than four, firhly convex, short, with a moderately impressed sufure: lust whorl a little llatened beneatl; aperture lunate; lip thin and sharp; umbilicus rather small.

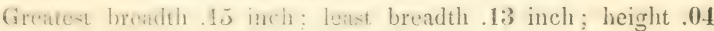
inch.

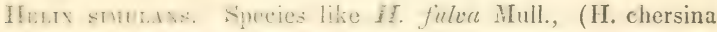
isa.) and firmerly supposet to be identical with that species. It is chichy dintimmished by numerons microscepic impressed spiral

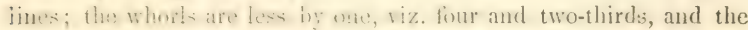
spire is les clevaterl, with $100^{\circ}$ mone divergence. It is of a glossy brown, deeper than in H. fulva.

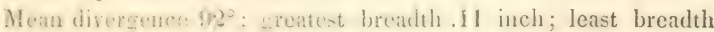
.09 inch; height .08 inch.

Helix ruscula. Shell subconic; brown; with fine strix of

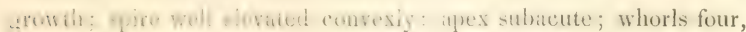

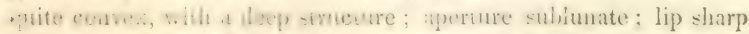
and thin; last whorl very convex around the small umbilicus. 
Mean divergence $30^{\circ}$; greatest breadth .1 inch; Ieast beadtl .09 inch; height .072 inch.

Ifecix dnunuts. Shell discoidal; greenish or pale comeons, with distant transverse raised lamelle; spire slightly elevated conrexly; apex obtuse; whorls four and one-half, rather convex, with a rather deep suture; aperture orbicular, execpt ats a little modilied by the penult whorl; lip sharp and thin; umbilieus very wide.

Greatest breadth .12 inch; least breadth .10:3 inch; height .0.; inch.

HeLtx APEx. Shell discoidal; whitish: with microsenpic spiral strix; spire scarcely elevated, convex; apex very ohtuse: whorls four, cylindrical, with a deep suture; aperture nearly circular; lip, thin and sharp; umbilicus very wide.

Greatest breadth .073 inch; least breadth .06..) inch; heiglit .(1): inch.

Helix imunde. Shell depressed conic; dingy white, sumctimes greenish and brownish, translucent; very thin, with very unequal strix of growth; spire convex, moderately elevated; : apes. very obtuse; whorls five, quite convex, with a deep suture: aperture transversely oval; lip extremely thin and sharp, reflected in the columellar portion; umbilicus not very wide, extending to the apex.

Greatest breadth .52 inch; least breadth .41 inch; lecight .22 inch.

Ifeurx perderressa. Shell discoidal : whitish or pale horn colored; with very fine transverse stria: spire concave or plane, with the last whorl often descending below the plane of the preceding: apex always depressed into the plame of the spire; whorls five, angular, on the upper side sloping a little below the plane of the spire, with a well impressed sature; aperture elliptical, a little modifierl by the penult whorl; lip thin and sharp; umbilicus as wide ats the last whorl, regularly concave and exhibiting all the whorls. The: following are the dimensions of a large specimen.

Greatest breadth .25 inch; least breadth .21:3 inch: leight .10.; inch.

IIElix angestuspira. Shell somewhat hemispherical; pale horm colored; very finely striated transwersely; spire depressed conic, with rectilinear outlines; apex very small and acute; whorls five and one half, quite convex, narrow, high, with a rather decp cuture: aperture lunate, oblinuely very long and narmw : mubilicus conlow small. 
Mean diverence abont $1: 33^{2}$ : greatest breadth .1:25 inch; least breadth .115 inch; height .98 inch.

IIt:ux rxeossiere. Shell subdiscoidal; whitish or pale horn color; with rery time strias of growth; spire scarcely clevated convexly; apex obtuse; whorls nearly five, rather convex, narrow, rather high, with a well injpresed suture; periphery of the last whorl nearly in the plane of the spire, subangular: aperture narrow aunl lmate: unbilicus more than half as wide as the penult whorl, subconcare. 'This species is intermediate between II. profffimis and $\boldsymbol{H}$. depressa.

Greatest breadth.1\%5 inch; least breadth. 1.5 inch; height dis inch.

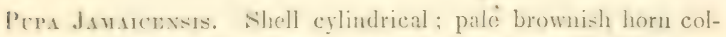
or; with fine obligne stria of srowth; spire tapering only near the stummit, into an obutes ajex: whorls five, quite convex, with a deep suture: aperture seninesil, with the right sicle longer, and shouldered above, and the transverse side a litte obligue: to the right of the midlle of the latier is a very promient stout tooth; on the middle of the colmmella is another cyually stout, but less prominent: on the right side is another proninent tooth directed between the two above-nentioned, and on each side of it a rather smaller tooth; lip moderatley reflected; with a very small umbilious.

'This species is more exictly cylimbical than $P$. scrvilis, Gould, I'. procere, Gould, dec. which hase a similar aperture; the upper and lower teeth of the right sils are t:lore conspicuous, and the shell is much smaller.

Length .07 inch; breadth .025 inch.

P'ri s.ATs. Shell very short, subeylindrical, truncated anteriorly; pale brown or horn culor: with very rewular rather distant. michoseonic transweres lines, which are more distinct on the upper whorls: spire eylimbrical; apex cenoid; whorls five, very convex, with it deep sumbe: last whorl making nearly a right angle between its lateral aud anterior surfices: aperture about two-thirds of at circle, whhout teeds; lip not reflected, with asmoth blunt margin: without umbilicus.

Length .075 inch; breadth .055 inch.

PUP. Inxodox. Shell ovate; brown; smooth and shining;

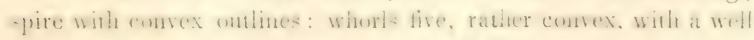
impressed suture; aperture semioval, with the transverse lip rather 
whigue, consandy with six weth, of which awo are on the transverse lip, the inture one being a little larger: two iceth are on the columella, the mper one being a little tareser and on the outer side are two, of which the howe one is a litte larger: unbilicus very small. 'This species resembies $\ell$ '. mente Say. Sere the excellent moneraph hy Dr. Gould of the l'upe of the United States in the Bost. Journ. Nat. Hist. Vols. III. and IV.

Length .085 inch; breadth .055 inch.

Pupa Exilrs. Shell tapering and much elongated; white; smooth: spire sicnter, with scarcely convex outlines: aprex obtuse: whorls nenrly six, rather convex, with a well impressed suture; aperture oblicue, long, contracied at both extremities, rather angular anteriorly; lip well reflected and thishened: on the lelt side of the aperture i: a strong transverse torth, and tiace is a smaller oblique tooth at the end of the columella; umbilicus very small. This species much rowenbles $P$. as an say, bat tapers regulariy from the middle of the last whorl, and is more slender.

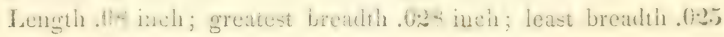
inch.

Srecinea rafror. Whell obliquely elliptical : pale amber color; extremcly thin, with rather coare unequal stria of growth: spire small; apex ateute; whorls three and snc-third; quite convex, with a well impreseed suture; aperture or al, acutely angular above, not oblique. 'This specics is intermediate, in the form of the last whorl and in is propurtion to the spire, letween $S$ comprstris Say, and S. obligue siay, but is misein thiner than either of thise species. s. Sagra (!) Orb., the allied species of Januica, is narrower and smoother.

Length .5:3 inch; breath .31 inch; length of aperture .4:3 inch: breadth : 2t inch. Of another individual, lengh . 43 inch; breadth .27 inch.

Succinea angustror. Shell very long ovate; brownish horn colored; well covered with strix of growth, not shining; spire long; apex acute; whorls three and one-half, long, rather convex, with a well impresed suture: aperture wal, rather small, not ohlique. A large specimen is .3 inch long and .16 inch broad; length of aperture .2 inch; breadth .12 inch. 


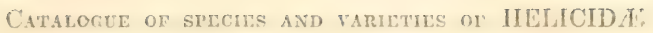
WHCH INHABit JaMAICA.*

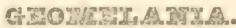

I. G. Jamaicensis Pfr.

3. G. expansa Ad.

2. G. minor Ad.

4. G. elegans $\Lambda$ d.

\section{OYIMTDละMTA}

5. (. prommita Ai.

6. C. lieardsleana $\Lambda \mathrm{d}$.

7. C. gracilis Wood.

S. C. elongata Chem.

9. C. Agmeinnz St.

10. C. alba Ad.

10. bis. C. Gossei Pfr.

11. C. seminuda Ad.

12. C. costulata Ad.

13. C. subula Fer. *

14. C. alabastrina Pfr.*

15. C.Humboldtiana, var. $\beta$ Pfr.*

16. C. variegata, var. ' ${ }^{\prime}$ fro.

17. C. montana Ad.

18. C. Gravesii $\Lambda \mathrm{d}$.

19. C. rosea P'it.

19.a." " var. magna $\Lambda \mathrm{d}$.

19.b." " " major $A d$.

20. C. ambigua Ad.
131. C. mlinirus Chem

22. C. rubella Ad.

23. C. aspera Ad.

2.1. C. obesa Ad.

¿5. C. brevis Pfr.

20. ('. c.tum:ar Ad.

(26.a." "var. intermedia Ad.

27. O. nobiiior Ad.

28. C. carnea $\mathrm{Ad}$.

28.a." " var. cerina $\boldsymbol{\Lambda} \mathrm{d}_{x}$

29. C. sanguinea Pfr.

30. C. Maugeri Wood.

31. C. inornata Ad.

32. C. simplex Ad.

33. C. Hydeana Ad.

634. C. rubra Adl.

3.5. C. Dunkeri Pfr.

(36. C. similis Ad.

37. C. tenellia $\Lambda \mathrm{d}$.

38. C. tenera $\Lambda$ d.

\section{ACEA.}

39. A. ligata Ad.

40. A. Jamaicensis Pfr.

41. A. procera $\Lambda$ d.

42. A. Griffithii Ad.

43. A. Phillipiana Pfi.

44. A.-elegans Ad.

45. A, venusta $P f r$.

di A. leucozmeniz Walch.
47. A. Dominicensis Gm.

48. A. curvilabris Pfr.

49. A. angiostoma Ad.

(50. A. Ingallsiana Ad.

ijl. A. unicolor $A d$.

52. $A$. nemorensis $A d$.

53. A. Phillipsii Ad.

Si. A. areuata Pfr.

$\therefore$ The specios which are thus designated are not in the collection of Amherst College. 
… A. vicina Ad.

56. A. propinqua $\mathrm{Ad}$.

57. A. Gossei P'fr.

55. A. costulata Ad.

59. A. abberrans Pfr.

560. A. pellucens Ad.

61. A. levis $\mathrm{Ad}$.
62. A. mienns Air.

63. A. iota $\Lambda$ d.

64. A. octona Chem.

65. A. striosa $\mathrm{Ad}$.

66. $\Lambda$. inusitata $\mathrm{Ad}$.

\section{BUITIVUS.}

67. B. minimus Ad.

68. B. striatellus Ad.

69. B. terebella Ad.

70. B. pauperculus Ad.

71. B. octonoides Ad.

72. B. pallidus Ad.

73. 13. monodon Ad.

74. B. nitidiusculus Ad.
75. B. leviusculus Ad.

76. B. rufescens Gray.*

77. B. erubescens Pfi.

78. B. immaculatus $\Lambda$ d.

79. B. zebra Mull.

S0. B. anomalus Ad.

81. B. mirabilis Ad.

\section{FUPA.}

82. 1. fallax (?) Say.

83. P. lata Ad.

84. P. contracta (?) Say.

85. P. tenuidens Ad.

86. P. hexodon Ad.
87. P. servilis Gould. 88. P. Jamaicensis Ad.

89. P. exilis Ad.

90. P. striatella (?) Fer.

\section{SUCCINEA.}

91. S. angustior $\Lambda d$. 92. S. Sagra Orb.
93. S. latior Ad.

94. S. contorta Ad.

\section{METT.}

95. H. Martiniana P $\mathrm{fr}$,

96. H. peracutissima Ad.

97. II. soror Fer.

98. H. cara Ad.

99. H. Chittyana Ad.

100. H. patina Ad.

101. H. fluctuata Ad.

102. H. acutissima Lam.

103. H. Bainbridgii Pfr.

104. H. Spengleri Hinds.* 105. H. lucerna Mull. 106. H. Olieniana Pfr.*
107. H. tridentina Fer.

108. H. Bronnii Pfr.

109. H. picturata $\mathrm{Ad}$.

110. H. sinuata Mull.

111. H. strangulata Ad.

112. H. anomala $\mathrm{Pfr}$.

113. H. aspera Fer.

114. H. Jamaicensis Chem.

115. H. angustata Fer.*

116. H. Cubensis, var. $\vartheta \mathrm{Pfr}$. 
iit. H. tunicata $\Lambda \mathrm{d}$.

118. $H$. sulphurea $\Lambda \mathrm{d}$.

119. H. Mac Murrayi Ad.

120. H. munda $\Lambda$ d.

1:21. II. tenerrima Ad.

122. H. graminicola $\mathrm{Ad}$.

123. H. nemoraloides $A d$.

124. H. Gossei Pfr.

125. H. subconica Ad.

126. H. fuscocincta $\mathrm{Ad}$.

127. $H$. virginea $\Lambda d$.

128. $\mathrm{H}$. fuscula $\mathrm{Ad}$.

1:9. II. immundit Ad. 130. II. ptychodes I'fr.

131. H. perdepressa Aì.

132. H. depressa Ad.

133. H. sincera Ad.

134. H. diminuta Ad.

135. H. apex Ad.
136. 11. inconspicua Ấ.

13\%. H. peraffinis $\Lambda$ d.

138. H. Boothiana Pfr.

139. $\mathrm{H}$. turbiniformis $\mathrm{Pfr}$.

1.40. Ii. Anthmima Ad.

141. H. angustispira $\mathrm{Ad}$.

142. H. ambigua Ad.

143. H. brevis Ad.

144. H. IIollandi $\mathrm{Ad}$.

145. $\mathrm{H}$. arboreoides $\mathrm{Ad}$.

146. H. similis $\mathrm{Ad}$.

147. H. lamellifera Ad.

11. II. pilir Ad.

149. H. Cookiana Gm.

150. H. torrefacta $\mathrm{Ad}$.

151. H. epistyliulum $\Lambda \mathrm{d}$.

152. H. epistylium Mull.

153. H. epistylioides Fer.

154. H. simulans Ad.

155. H. dioscoricola Ad.

\section{PROSERPINA.}

156. P. nitida Sowb.

157. P. opalina Ad.

New Arroctub which inhabit Jamaica. By C. B. Antus. Oet.1849

Melampus coronates. Shell obconic; reddish purple; with several spiral punctate striat and di-sau transverse stria, and a deciduous epidermis, which is produced into as small spine at each of the principal transerse strie on the spire: spire rather short, with outlines slightly concave; apex very acute; whorls about seven, slightly shouldered, with a moderately impresend suture; aperture with a large solid spiral prominent callus or woth on the columella. The two specimens betire me may lie poung thells, but probably belong to a new species.

Length .11 inch; breadth .07 incl?.

Pedipes ovalis may be a variety of $\boldsymbol{P}$. quadividens $\mathrm{P} f \mathrm{fr}$; but when full grown it is oral: the spiral rils on the last whorl are broad and approximate, and on the whole shell they are smooth, without the irregular micruscopic sranulations of P. antadridens. 
the color is yellownh brown or waxen: the aperume is smmbar as that of Dr. Pfeilier's species, bnt the tooth of the right side is lese conspicuous.

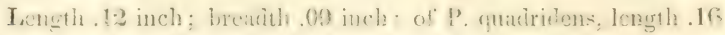
inch; breadth .135 inch.

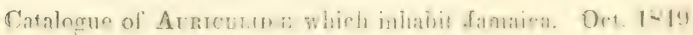

\section{WVITIATMETS.}

1. M. coniformis Brue.

2. M. flavus Gm. Syn. Auricula moniic Lam.

3. M. pusillus Gm. Syn. Auricula nitens Iam.

4. M. coronatus $\Lambda \mathrm{d}$.

5. M. cingulatus Pfi:

\section{PIDIPIS.}

6. P. quadridens Pfr. $\quad$ \% P ovalis Au.

Descriptions of supposer new species of Fresh Tiater Sinclis which inhabit Jamaica. By C. B. Adars. Oct. 1849.

Paludina Jamaicensis. Shell ovate-conic; translucent or subiransparent; greesi, someinues wish a tinge of brown; rery smonth. spire with the outlimes weary rectilinen; apes acute, persistent whorls six, juite conver, very regularly rumded aperture ovate. acute abore: with an monilical grone between the lefi side of the lip and the Iast whorl.

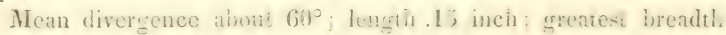
.1 inch; least breadth .08 inch.

VAlvata Prguea. Shell convex above; concave below; color* ? with fine strix of growth; spire convex, moderately elevated;

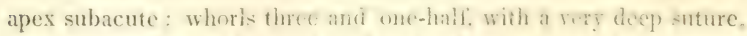
very accurately rounderl and Fathe rapidil increasing in diancter: so that the shell resembles an elongated cone wound in a spiral

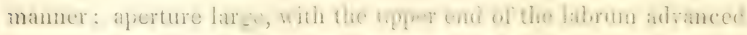




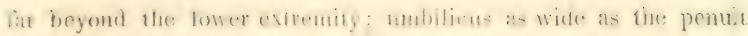
whorl. The following are the dimensions of a large specimen.

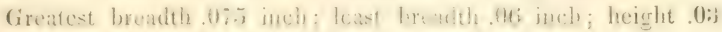
inch.

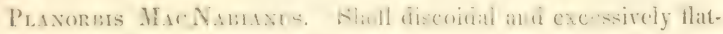
tened, like $P$. vortex; brownish horn color; with microscopic crowded tran-ber-e stric of arowth: sire a litth more concare on

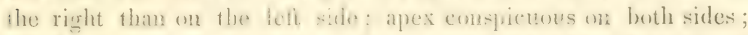
whorls six, with a well impressed suture on bot sides, plamulate on the lefi side and a little conves on the right sille: last whorl with an angular periphery in the plane o! the leth side; aperture very

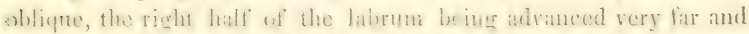
sbruptly heyond the left hall, erpeciol't in old shells, in which the advance is equal to twice the diameter of the aperture.

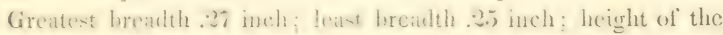
last whorl .04 inch.

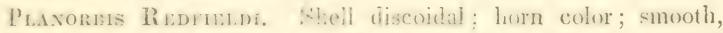
ath a lew mieroscopic interripted spiral strie; spire more widely and deeply concave on the hefi than on the right side; apex visible on both sides; whorls nearly four, wider on the left side, with a well impresed and margined stume on both sides, subplanulate on the left, convex on the right; bist w horl spreating much through a

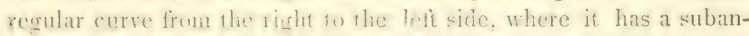
gular periphery, martow an the telt side labrun with its right half advanced hesonel it: left h! at spare cyual to the diameter of the aperture.

Greatest ireailh . 125 incll least hrendth .16 inch: height of Iast whorl .065 inch.

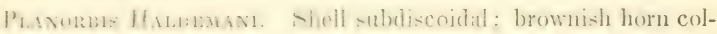
or; with very fine strix of growth, and several spiral series of microscopic punctures; spire very narrow; apex deeply sunk on both sides; whorls five, rather convex, more convex on the right

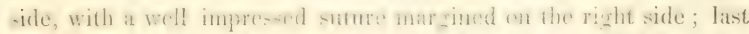

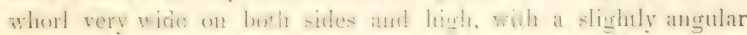

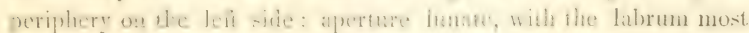
advanced at one third of its length from the right extremity.

Greatest breadth .1.t inch; least breadth .125 inch; height of Iast whorl .07 inch.

Pranormis decriens. Shell discoidal; pale horn color; witl. hine stria: of growth and finer microscopic spiral strie; spire wide, 
a little concare on both sides: apex moderatcly depressed, unore so on the right side; whorls five, rather convex on the right side, subangular on the left, with a well impressed suture; last whorl not large, with the subangular periphery nearer to the right side; aperture semioval; much advanced at the right extremity. This species resembles $P$. pullidus $A d$, which has a less number of whorl: of which the last is much wider; that shell is also higher.

Greatest breadth .365 inch; least breadth .32 inch; height of the last whorl .09 .

Plinorbis afrris. Shell discoidal : loorn color; with coarse. strix of growth; spire wide and moterately concave on both sides; apex very deeply depressed into a minute pit and invisible on the right side, conspicuous on the left side; whorls about five and onethird, convex with a deep suture on the right side, on the left side angular, with the suture at first on the angle for nearly three whorls and then descending into an acute angular chamnel; last whorl rather large, moderately tmmed to the left; aperture semioval; labrum moderately adranced on the right side. 'This shell is very similar to $P$. lentus Say, of which it may possibly be a variety. Its altitude is less, and the right side is more uniformly concare. Perhaps this is a case of specific identity with plural origin.

Greatest breadth .6s inch; least breadth .53.5 inch; height of last whorl .21 inch.

Var. $a$; brownish red, with coarser striæ of growth, the outer whorl more sharply angulated, and higher.

Greatest breadth .5\% inch; least breadth .55 inch; height of last whorl .22 inch.

Cyclas Veatleyi. Shell oval; liom color with a tinge of brown; extremely thin, with fine strix of growth; valves very inequilateral, with a moderately conrex disk; anteriorly both short and low, with a well rounded margin; pusteriorly very high and subtruncated; licaks small but prominent; cardinal teeth small; lateral teeth moderately dereleped, smewhat remote. Very rare.

Length .21 inch; height up the middle of the posterior side .15 inch; breadth .105 inch.

Crclas pygalea. Shell oval; color — ? ? not very thin proportionately to its size, with microscopic stria of grewth; valves somewhat inequilateral, with a very convex ciisk: anteriorly short

*I was unable to find any living or fresh specimens. 
but high and searcely truncate; posteriorly long but much lower, somewhat tapering to a well rounded extremity; beaks wide, not prominent: cardinal teeth small and lamellar; lateral tecth moderately developed, not remote.

Length .083 inch; height .07 .5 inch; breadth .05 inch.

Catalugue of Fresin Watro Snelus, which inhabit Jamaicit.

By C. B. A Dams. October, 1849.

1. MIELANOPSIS lineolata Gray.

2. IVEIAIVIA spinifera Ad.

3. VATVATA pygma Ad.

4. PAIUDINA rivularis Ad.

5. " Jamaicensis Ad.

6. AMPUIARIA fasciata(?) Lam.

7. PUANORBIS MacNabianus Ad.

S. " $"$ Redfieldi Ad.

9. " Haldemani Ad.

$10 . \quad$ " dentiferus $\mathrm{Ad}$.

11. " pallidus Ad.

12. " decipiens Ad.

13. affinis Ad.

14. ANCYLUS obscurus (?) Hald.

15. PEYSA Soverbyana Orb.

16. IIMNAIA umbilicata Ad.

17. CYCIAS pygma $A d$.

18. " Veatleyi $\Lambda$ d.

Remarks on the distribution of the TerRLSTRIAI AND FrESI-WATER Morcessa which inhabit Jamaica. By C. B. Ansus. October, 1819. Read before the American Association for the Promotion of Science, August 16, 1849.

In the following statements perfect accuracy in the details is not attempted. Subsequent explorations will enlarge the total number of known species, and modify our views of the distribution of specie; both by the discovery of new species whose distribution is very 
Aimited, ant by asecertaining a nider distribution of some which are now knom.n. The ralintity also of sereral of the sqeecies which have been enumerated in the preceding catalemues is even more than doubthil, as intimated in the captions of the articles. Additional specinens and the sugrestions of experienced zoologists will enable us, we lope, at some fiture time to determine more satisfactorily many of these dillicult and doulthinl cases. With some confidence, howerer, in the general correefnews of the following riews, we think it unnecessary any longer to withhold them.

A fact, which affects the visiter from a northern climate with astonis!mest, is the great profusion of the terrestrial species, and their accumulation in certain districts. In the parish of Manchesier, a region four miles long and one mile wide contains one hundred species,-as many as the whole number native in North America east of the Missiscippi river. After becoming acquainted with their stations and localities, at collector unight easily obtain eighty or nincty species in one day, for most of them are sufficiently numerous in individuals to render his suecess certain with ordinary skill. Of the : 2 .5 terrestrial species which have been enumerated, more than two hundred were collected by the writer in person in a hasty expluration of onc-ienth of the surfice of Jamaicat. From the very limited distribution of most of these species, we may rea-

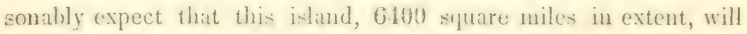
furnish from 3.50) to 404 good species. Long might a collector continue his explorations, and make good his maxim-nulla dies sine specie.

It slould not, however, be supposed that the species have been distributed, in such profusion, orer all parts of the island indiscriminately. The trappean, syenitic, and sandstone districts are as deslitute of land shells, bith of species and of individuals, as the barren surfice of New England. In the limestene districts, but few species will be found on the Newer Pleiocene (?) or rubble limestone. They abound on the more perfectly consolidated limestone of Meiocene (?) age. Here the numerous and violent dislocations of the earth's crust by earthquakes, fir a long succession of arges, have broken the surfice into immumerable cavities and labyrinthine passages. 'These have heen only partially filled with soil, since the mechunical decay of the well consolidated limestone is slight, and no gacial agency has ever sumenhed down the asperities of the

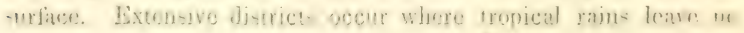


sianding water, and where no risers llow, or where the rivens wh luni

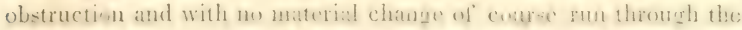
base of lolty momntains. In the dense and ranied arejiral vegetation abore, and in the immunerable plices of retreat benesth the surfice, we find the paradise of snails. They, wilh a variety of articulated animals, form at gnanoid soil, which renders the ahmos naked rocks

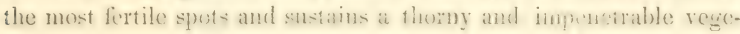
tation.

The difference in the extent of the marine and of the terrestrial species is remarkable. A few of the marine species of Jamaica occur also in the New England States : and many are loumd in the Sonthern States. Sevral oreur in Weot Atrica, and in the Med-

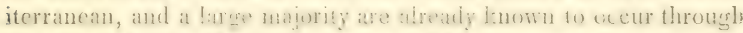

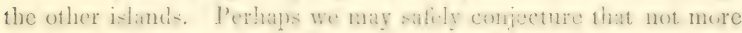
than ten or fiftecn per cent. of the marise apecies are pectiar to the island. The same law gorems thoze genera of Colimacea which. are maritime in their habit, riz. Truncatella, lialines, and Melampus.

With the species of Molluaca, which are aricty terestrial, the law of distribution is reversed. Prebahly not more than six to nine per cent. of the species are common to any other islauds. In the Thesaurus Conchylinum of G. B. Sowerby, Jr., Cirlutoma articulatum is said to have come fren Demerarat and the Antilles: anci the hahitat of Holirine pieta Fer. is said on be Martinique and Jamaica. The habitat of II. hwemetoma Morice and of C. Adamsi Plr. (C. cremulatum (iray) is "the Antilles, and yet more generally, C. fascia Gray and H. neritella Lam, are said to come from the West Indies." Thuis of the 9i eperculated specien. iwo only (with a third which we have not enumerated as a Jatuien thell) are alfirmed to occur in other islands.

Of the Intunat of Jamaica, the ecnas Genmelania has been found only in Jannical. Of Cylindrallu, C. hreris is stid!, by Dr. L. Pfeifier on the autlurity of Petit, woceur in Martinicue, and Cuba is doubtully mentioned ats its habitat. Yariety af C. Itumboldtiana, and variety $z$ of $\mathrm{C}$. varicgnta, both ('uban species, are said by Dr. Pefeiller to oceur also in Jamaica. C. Manteri, a Jamaicaspecies, is said by Dr. P'. on the authority of Th. Itoruberk, fo oceur also in St. Thomais. 'ile remaining thirty suecies ane peculiar to Janaica.

\footnotetext{
* Cyclostoma Saulix was introduced erroneously into the Catalogue on page 16 , No. I.

t See catalogue of species, page 39 .
} 
Of Achatina, A. octona is rery widely distributed through tie: West Indies, and is said by Mr. Reeve to occur in the Polynesian islands. It has probably been distributed nore or less by human agency. In Jamaica, it occurred only in Kingston, in a small garden near the shipping. A. leucozonias is said by Ferussac to occur in Martinique. It has twice been given to me in Jamaica as a native species, although I have not found it in place. A. Dominicensis is said to occur in Hayti. I have found it in the eastern part of Jamaica. According to Dr. Pfeifler, his variety of $z$ of A. venusta occurs in Demerara. The remaining twenty-four spccies are known only as natives of Jamaica.

Fifteen species of Bulimus have been found in Jamaica, of which one only, B. zebra, is known to inhabit other islands. The labits of this species, which lives on cultivated and other shrubs, lattice fences, \&c. near human habitations, and its rery local distribution in such situations, suggest that it may have been introduced.

Of the more general distribution of the small species, we have a remarkable example in the genus $\boldsymbol{P} u p$. Of the nine speeies know? to me, one appears to be identical with $\mathrm{P}$. contracta, which is well known to occur over a large part of the United States. As far north as $44^{\circ}$ lat., I have frequently found it in Vermont. In certain localities the Jamaica shells of this species are rery abundant. Another species, which I have found in Jamaica and received froti Cuba, is not distinguishable specifically from P. fallax, which has a similar distribution in the Lnited States. The West Indian rariety however is thinner both in the lip and in the walls of the shell; and, if a slight difference, especially when constant, should have more weight in distinguishing species where plurality of origin is probable, perhaps this variety is entitled to specific rank. P. servilis was found by Dr. R. E. Griffith in Santa Cruz. P. striatella, of which one specimen was given to me in Jamaica as native, is said to occur in Hayti, Porto Rico, \&c. But this species belongs to the group of large and solid Pupa, which are more maritime in their habits.

\section{[TO BE CONTINUED.]}

Errata.-On p. 18, line 8th from the bottom, for tip read lip.

" 40, after 75 B. løviusculus Ad. insert 75 bis. B. subula Pfr.

Notr.-Ten of the fresh water species will be sold at the same rate as the 150 species of land shells. See Note p. 15. Some additional rare species in all these families can be had at $50 \mathrm{cts}$. each, with one or two specimens of each. 


\section{CONTRIBUTIONS TO CONCHOLOGY.}

\section{No. 4 .}

Remaris on the distrinution of time Terrestrial and FresirWater Mollusci, Which inmabit Jamitca.-Continued from p. 48.

Four species of Succinea inhabit Jamaica, one of which is probably identical with a Cuban species, S. Sagra. In this genus the paucity of specific characters is such, that plurality of origin may often be undistinguished by well marked specifie differences. Specific identity in such genera is by no means indicative of unity of origin.

Sixty-one species of Helix inhubit Jamaica. H. Cubensis is a Cuban species, of which variety 9 is said by Dr. Pfeifler to come from Jamaica. H. turbiniformis is said by the same authority to occur rarcly in a province of Cuba ; it is common in certain parts of Jamaica. H. Boothiana is also common to Cuba and Jamaica. H. angustata is said to occur in Hayti and Jamaica. H. Bainbridgei, the heaviest species of land shells in Jamaica, which oceurs in the central prarts of the parish ef Mranchester, is said by Dr. Pfeiffer, on the authority of Mr. Bainbridge, to have come from Demerara. Dr. R. E. Griflith found II. sincera in Sinta Cruz. The remaining fiftyfive species have hot yet been found out of Jamaica. The two species of Proserpina are not linown to inlabit any other islant.

Thus of the two hunlred and fifty-seren species which are strietly ferrestial, twenty-two may have been fund ont of Jamaica. If it should be thought that the further exploration of other islands and of the mainland should adt to this latter number, it is equally probable that the number would be much reduced by reruiring alsolute certainty in the testimony on which Jamaica specics have been referred to other habitats.

Only nineteen fresh-water species of AIollusea in Jamaica are known to me, all of which I have collected in person. The number of genera is remarkable. Althongh Planoritis has seven species, the remaining twelve species belong to ten genera.

There are no Naiale, and there are but two very rare species of 
Cyclas. The Limma is not distinguishable from a Culan species, nor from L. umbilieatia of Miassaldusetts. The l'hysa is probably P. Sorerhyama, of Cuha also. The Ancylus is not clistingui-lable from A. obseuras of I'cmeylvania. Anjullaria fateciata is said to oceur in several other pauts of tropical Ancerica. Iut these four are genera in which there is a great paucity of spceilic characters. The remaining species have not been illentified with those of other piaces, unless Flanorhis aflinis br: identieal with $P$. lentus. In some localitics, seyeral of the fresh-water species oectir abmolantly ; bnt these farorable stations are not numerous. Sitreans are very frequent in many parts of Jamaica, but they are mostly mountain torrents, which rarely present favorable stations for Mollusea.

It has been chserved by naturalists, that in tropieal Zoology, while the number of species is nuch greater than in northen regions, the number of indivituals is much less. This is eminently true of birds and fishes, and of some other classes. Perhaps this generalization does not hold true of any entire class of Molli:n and if it be applierl to the terrestrial Kiollusea of the Western Ilemistinere, the rever:o is remarkably erident. In Jamaica, many of the terrestrial species exist in a profusion to which there is no parallel in the temperate and northern regions of North America.

A comprason of the number and of the distribution of the marine and of the terrestrial species, suggests an interesting conclusion. If the same general fact is true in all the larger islamls, viz.: that the number of terrestrial species iu each island is from one third to one half the number of the marine species, while i per cent. of the former and 75 or 80 per cent. of the latter are common to two or more islamels, - it follows that the total number of terrestrial species in the Antilles must exceed that of the marine species.

With this extremely local nistribution of the terrestrial Nollusea in the Wrest Inrlies may be associated the great fact of their geological liristory-that these islands have, since the later 'Tertiars periods, been in the process of eleration,- that the $y$ are the harhingers of $\alpha$ future continent, unlike the gronps in the iacific, which are the remairs of ancient contim....ts. Coincilent with these two general facts the Tifest in Indies is also a third,-that their coral reefs are all fringing, and that coral lagoon islands are wanting.

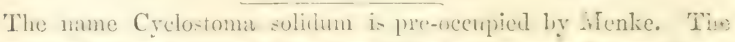
species, which was dercribed moicr this mame on pare 7 , mey therefore receive the name of $\mathrm{C}$. JAYANum $A d$. 
THMARES ON TIIE WEIGHT OF THE SHELLS OF CERTAIN SPECIES OF Commacea. By C. B. Adams. Nov. 1849.

Tre average weight of the full grown shells of a given species of the Mollusca is an interesting item in its history. The ratio between their size and weight varies so much in different species, that the usual precis statements of the former convey no information of any value respecting the latter character. We give therefore a few examples, which un rlucle the most minute terrestrial species that exist in the collection of Amherst College, and which are probably among the most minute that have been hitherto discovered. Several specinens were weighed together, both for the purpose of diviling any error in the process, and of oltaining an average result. Using the balance of analytical chemistry, and taking ten or more individuals of the minute species, we obtain quite exact results. The principal sources of error in the comparison of species arise from the difference in the mode of preservation of the shells. In the very small species, the animals are usually dried up in the shells; but if not taken. alive, they may have lost more or less of the solid matter in the animal. But the difference of weight resulting from this cause cannot be cunsiderable as compared with the entire weight of the shell, for the total anil matter in the soft parts is small. In many operculated species, the operculum is unlknown, and we have therefore excluded this part in all the examples of such species.

In the following table, the first column of fignures contains the number of specimens which were weighed together, and the second column -their agrgregate weight, and the third-their average weight, in decimal parts of a grain.

1. Cyclostoma avena Ad. Jamaica. 20

2. Helicina lineata Ad. " 10

3. " depressa Gray. " 10

4. " affinis Ad. " " 10

5. " Adamsiana Pfr. " 10

6. " solitaria Ad. " 10

7. " megastoma Ad. "

8. " costata Sowb. " " 10

9. " hæmastoma Moric. " 1

10. " Jamaicensis "Sowb. " 10

4.025

.28

2.14

2.916

4.85

8.21

1.82

10.92

1.928

21.21
.2012

.214 .2916

.485

.821

.91

1.092

1.928

2.121 
11. “ neritella Lam, Jamaica 10

26.585

2.6585

12. " albolabris Ad. " 5

22.11

4.422

13. " maxima Sowb. "

71.43

17.856

14. Trochatella tenuis Ad. " 10

15. " Josephinæ Ad. " 10

.173 .0173

16. " pulchella Gray. " 5

9.83 .983

17. " Tankervillii Sowb. "

8.51

1.703

18. Lucidella aureola Gray. " " 10

42.08

8.416

19. Stoastoma Blandianum Ad. " 20

6.97

.697

20. " Redfieldianum Ad. " 50

.08

.004

21. " Leanum Ad.

50

22. " Jayanum Ad.

23. " Fadyenianum Ad. " 15

.39

.0078

24. " Gouldianum Ad. " 30

.6

.012

25. " Cumingianum Ad. "

26. " Pfeifferianum Ad. "

27. " pisum

Ad. “

.59

.0197

.025

.025

.303

.0606

28. Truncatella fusca Phil. Naples. 9

1.75

$.175^{\circ}$

29. " Adamsi Pfr. Jamaica. 10

.06

.00667

30.

scalaris Mich. " 10

.63

.063

31. " costellaris (?) Risso. Fiji Is's. 10

1.35

.135

32. " succinea Ad. Jamaica. 11

5.17

.517

7.59

33. Pedipes quadridens Pfr. " 20

34. Geomelania minor Ad. " 20

7.89

.3945

35. Cylindrella pygmea Ad. " 100

5.3

.265

36. " tenera Ad. " 1

1.17

.0117

37. " Beardsleana Ad. " 20

.06

.06

38. Achatina iota Ad.

20

39. " aberrans Pfr.

" 12

40. Bulimus minimus Ad.

" 50

41. Helix apex Ad.

" 4

" 20

1.41

.0705

.03

.0025

42. " minuscula Binney. Vermont. S

43. " pulchella Mull. " 100

44. Pupa Jamaicensis Ad. Jamaica. 100

45. " milium Gould. Vermont. 4

46. " minutissima Hartm. Bavaria. 15

1.45

.029

$.016 \quad .004$

$.078 \quad .0039$

.11

.01375

2.3

.023

.3

.003

$.016 \quad .004$

.07

.00467

Pupa minutisima (No. 46) is the least of the European land shells with which we are acquainted. Pupa miliun (No. 45) is the least of the species which inliabit the United States. Three of the species 
of the laml shells which inhabit Jamaica are of less size than either of these; viz. Helix apex (No. 41,) P'upa Jamaicensis (No. 44,) and A.hatina iota (No, is.) The latter is probably the least of all the known species of terrestrial molluses. Two others (Nos. 19 and 40) are of the same size as Pupa milium.

It follows that the least of all known terrestrial shells exist in tropical regions. A subsequent investigation of the size of the maJine species, which we lave collected in Jamaica, will also show a lirge number of extremely minute shells. From the well known fact that the larger species vecur only in tropical regions, it has by many been too hastily inferred that only temperate regions contain a large proportion of very small species. The difference of zones is not that one extreme of size is found in the tropies and the other in temperate climates, but that, while both appear in tropical countries, one extreme is deficient in temperate regions.

Within the tropics, however, there appears to be a great difference in the average size of the land shells of different regions. In the West Indies and in the Polynesian Islands, there is a great proportion of small species. But in Brazil and in the Philippine Islands, there are very few small land shells. It is remarkable that this purely geographical difference greatly exceeds the average difference in the species of diflerent zoncs. 'The cause of this prominent fact in the plan of creation it may not be easy to discover.

Theseription of a supposed new speeies of Colcabelda. By C. B. Adams, Jan. 1850.

Columeria orecordes. Sheil long ohovate: yellowish brown, rarely hackish brown, irregularly mottled with large angular spots of white, often with a band of white aromm the midlte of the last whorl, with the apex white: with num rous fine spiral stria, of which those that are on the upper part of the whots and at the anterior extremity of the shell are eo:arstr; with exessively minute unequal strix of growth: apex acute: spire with rery comeave ontlines: whorls nine, the penult whol only being rery convex, with a well impressed sufure, which ne:ar the end is rapilly curved upwards towards the apex : aperture very long and linear: labrum much produced in a broad 


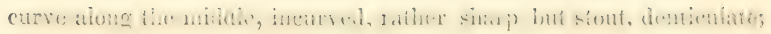
within: labium with a deposit of moderate thickness: columella somewhat prochuecl.

Hean divergence of the spire $50^{\circ}$; length of the spire .22 inch total length .7 inch; breadth .26 inch.

Habiтat-Bahamas. Fine specimens were collected on Turlis Is. by Dr. A. Barrett of Pittsfeld, Niass. 'This beautiful shell is well

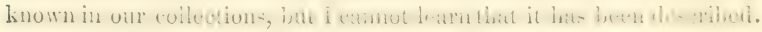

Notes on the sxxonym of certain marine shells. By C. B. Adams, Jan. 1850 .

Plenotoma plicuta Ad. Bost. Journ. IVat. Hist. III. p. 318. pl. 3. f. 6. 'This nane having been pre-oecupied by Lamarck for' a tossil shell, my species may take the name of PLEUROTOMA PLICOSA.

Plewoloma decussute Mfucfillimury Mioll. Scot. p. 172. This species, although perhaps figured in Brown's Illust. in 1827 with the name Fusus decussatus, was first described in 1844, by the industrious and learned author of one of the most complete local Famna Molluscorum which has erer appeared. 'This name was therefore anticipated by Mr. Couthuoy for a Niassachusetts shell in Feb. 1839. 'The Scottish species may therefore take the mame P. MAcGiLLIyedit.

Pleurotoma violacee IIinds. Proc. Zool. Soc. Lond. March 2S, 1843. 'The name of this species was anticipated by me in January 1842, for a species which inhabits Maine. Mr. Hinds' species may therefore take the name of P. ReErr.

Pleurotoma nigrescons Ad. Proc. Bost. Soc. Nat. Ilist. Jan. 1, 1845, appears to be identical with $P$. nigrescens Gray (Ad.?) IIss. in Reeve Conch. Tcon. pl. XXVI, No. 28j, Nor. 1845. This species, with $P$. minor $A d$. and $P$. fuscolinealc $A$ id., was sent by me in January 1845 , to the British NIusem, where they were seen by Sir Robert Schomburgh. See his eatalogue of TVest Indian shells in Ilist. Barbadoes, pp. 659-66t.

Pleurotoma fuscolineala Ad. Proc. Tost. Soc. Nat. Hist. Jan. 1 1545 , very closely resembles, and perhaps is identical with $P$. scalpta

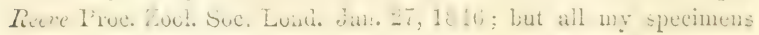


are "minutely reticulated," rocrer smooth. This species was described by Mr. Sowerhy in Proc. Zool. Soc. Lond, Narch 12, 1814, as Columbella monilifere, and was also deseribed and figured in the Thes. Conch. Columb. p. 144, p\}. 40, fig. 177 . The figure fititlfully exhibits the sinus, which is not mentioned in the text. The name of the species will be Pleurotoma monilifera (Columbella) Sowb.

Pleurotoma albovittate 1 1d. Y'roc. Bost. Soc. Niat. Hist. Jan. 1, 1845, appears to be identical with $P$. Inteo-fasciatc Reeve Proe. Zool. Soc. Lond. Oct. 28, 1845.

Pleurotoma trilincuece Ad. Proc. Bost. Soc. Fat. Iist. Jan. 1, 1845, appears to be identical with $P$. trifasciatu Gray MIss. in Reeve Conch. Icon. XxxiI, No. 297, Dec. 1815. It is probably a Mangelia.

The following species were described as Pleurotomne in Proc. Bost. Soc. Nat. Hist. Jan. 1, 1845, but may be referred to Mangelia of Lench, as characterized by Mir. Hinds in Proc. Zool. Soc. Lond. 1843, p. 45 .

Mangelia albovittata (Pleurotoma) Ad.

$\begin{array}{llll}\text { " fusca } & \text { " } & \text { " } \\ " & \text { clubia } & \text { " } & \text { " } \\ \text { " } & \text { trilineatia } & \text { "6 } & \text { "6 } \\ \text { " } & \text { cuncliclissima } & \text { " } & \text { "6 }\end{array}$

Buccinum concinnum Ad. Proc. Bost. Soc. Nat. Hist. Jan. 1, 1845, is a Columbellia, and may take the name of C. DECrpiens.

Columbelle purpurascens Al. Proc. Bost. Soc. Nat. Mist. Jan. 1, 1845, appears to be identical with C. clomitor Soub. Proc.Zool. Soc. Lond. Alarch 12, 1841, and in Thes. Conch. Columb. p. 143, pl. 40, fi g. 17:3. 'This firure is colored like a fuded specimen.

Buccinum obcsum Ad. Proc. Bost. Soc. Mint. IYist. Jan. 1, 1845, is a Columbella, and may take the nime of C. Osess. The color is more frequently pale yellowish brown, with a rery dark spiral band of the same color on the lower part of the whorls of the spire and on the summit of the conrexity of the last whorl, with another similar band anteriorly. This species is very elosely allied to C. atomelle Ducl.

Fote on Geomelania Jemaicensis P/f. Thite No. 3 was in press, I receired from Jamaica a fine specimen of this shell, precisely like the Cunningian specimen. 'That the difierenees between this shell

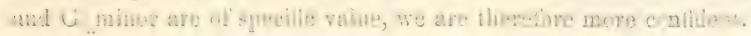


My friend, IIon. Edward Chitty, informs me that he has detecterl an operculum in Geomelania, and that he has some additional species.

Descriptions of supposed new species of Mirme Sirelds, which inhabit Jamaica. By C. B. Adams, Jan, 1850.

Marginella nivea. Shell obovate, white, translucent, with numerous spots of opaque white: smooth and slining : apex acute: spire small, short, vitreous, wholly oparue white: whorls about three and one-half: aperture long, eifuse ahore: varix stout, produced to the apex : columella with four prominent plaits.

Mean divergence about $100^{\circ}$; length of spire .06 inch ; tutal length .37 inch; breadth .22 inch.

This species resembles $M$. pminos Ifinds, but is much smaller, more regularly obovate, the spire is shorter, and the coloration is different except in the opaque white spots.

M.Arginella albi. Shell obovate, wite: pure opaque white: smooth and shining: spire concealed, with a shallow pit in its place: labrum well excurred in its upper part, produced to the summit, rather sharp edged, thick, smooth within: columella with four or fire plaits, of which the upper one or two are inconspicuous.

Length .205 inch; breadth .13 inch.

MLarginella abbretiata. Shell oblong, but much contractel anteriorly: white: smooth and shining: spire rery short : apex rather obtuse: whorls abont three and one-third: labrum incurved and contracting the aperture: varix produced a little way on the spire: columella with four plaits of which the upper one is small.

Mean divergence about $90^{\circ}$; length of spire about . $0.4 \mathrm{inch}$; total length .22 inch; breadth .11 inch.

This shell resembles $M I$. lectee Thi, but is much shorter, and is broader at the top of the last whorl; in .I. lactea the rarix extends farther on the apex.

Marginella fluctuata. Shell obovate: whitish, with very narrow longitudinal strongly wared lines of lrown, which extend from the summit to the anterior extremity, and which, heing more conspicuous at the summit and at intervals, form spiral scries, a little alore and a little below the greatest conrexity of the shell : spire entirely 
concenled by the last whorl, with a callus reaching from the lip orer the summit: laturum rather sharp, finely dentienlate within: columelIa with five, platits, the anterior of which are larger. This specents resembles $M$. frumentum Sowb.

Length .17 inch; breath .11 inch.

Motid ansilemera. Shell between a fusiform and rhomberial slatpe: brownish black, with a white sporal band which is a little above the suture, and which is small and indistinct on the upper whorts and increases with the progeress of growth, and which is dilated into spots on the ribs : with rather acute longitudinal ribs, about fourteen on each whorl, and numerous excessively minute unequal raticed spiral lines, which are larerer at the anterior extemity, ame more nolulous on the ribs; anteriorly with a broad well impressed groove. which commences in the aperture above the platis, and contrats the general form : aprex acute: spire with nearly rectilinear outlines: whorls eight or nine, rather convex, with a rather deep suture: columellat with four plaits.

Mean diverenenes $\left.t^{2}\right)^{2}$; length of spire .38 inch; total length $.7 \cdot t$ inch; breadth .36 inch.

'This species resembles 7 . mierozonias $L$ rem. in which the ribs are obtuse, the outlines of the spire are more convex, and the general form is narrower. It also, resembles $M$. leucodesma Reeve.

Mrtra albicostata. Shell fusiform: dark brown or reddish brown, with whitish ribs, with a spiral band of a darker shade of the same, which is sarcely interrupted on the ribs, and a spiral white band whirh comenenees on the last whorl near the summit of the aperture: with ohtuse longitulinal ribs, alout 16 on each whorl, which are nearly obsolete in a broal shallow groove near the anterior extremity: with spiral stria in the intercostal spaces, and a few spiral ratised nomblous lines anterimly, of which the larger is continuous with the upper columellar plat : apex ohtuse: spire with the outlines quite convex: whorls six, modrately convex, with a well impressed suture: apreture narrow : columclla with four plaits, of which the two lower are small and :pproximate, and the two upper are large and distant. This species resembles. $\boldsymbol{M}$. cavea Reeve.

Meati divergence $10^{\circ}$. Length of spire .3.5 inch; total length .59 inch; breadth .31 inch.

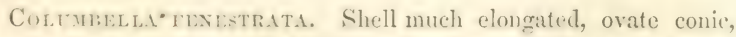
sub-angular on the mislille of the last whorl: oprague white aromel the aperture, with, at the summit of the whorls, a spiral opaque white bant, which is interrupted by the angles of an arproximate scries of 
brown spots, which have the form of the summits of Gothic windows, and in which the deep brown of the summit fades in descending to the middle of the whorls, where the shell is transparent; with three linear spiral series of alternating white and brown on the middle and anterior part of the last whorl: with spiral stria anteriorly, otherwise smooth: apex acute: spire with the ontlines nearly rectilinear: whorls eight, nearly plane, with a lightly impressed suture: aperture in the form of a o but rather wider: labrum thickened and well excurred, smooth within, sinuate albore.

Hean dirergence $30^{\circ}$; length of spire .16 inch; total length .25 inch; breadth 08 inch.

Columbela costulata. Shell morlerately elongated, ovate: whitish, with an ill-defined spiral band of very pale yellowish brown on the middle of the whorls, with the same color anteriorly; with a series of lange deep brown spots at the summit of the whorls and also before the middle of the last whorl: with obtuse longitudinal ribs, about twelse on ench whorl, and unequal spiral strix : apex subacute: spire with moderately convex outlines : whorls about fire and one-half, a little consex, with a well impressed suture: aperture small : labrum with a broad highly polished raris, denticulate within, sinuate abore.

Nican dirergence $40^{\circ}$; length of spire .12 inch; total length .19 inch; breadth .09 inch.

This species was described in IIss. fire years since, but being informed that it was identical with C. pygmaed Suwb just published, I suppressed the description and distributed the shell as C. pygmaea. It proves to be quite distinet.

Terebra JAmArexisis. Shell not rery slender, regularly tapering above the last whorl: slate colored, with a series of darker spots on a white spiral stripe next below the suture; with a white spiral line emerging from the top) of the aperture, and a brown one from the mildle of the same; white between the brown stripe and the columella: with longitudinal unequal wrinkles, which extend from the suture rearly to the mildle' of the whorls; with execssirely minute lightly impressed spiral strix: apex acute: spire with the outlines almost rectilinear: whorls twelve or thirteen, nearly plane: aperture long orate: notch wide: columella slightly twisted. This species closely resembles the more slender T. stylata Hind's of the Philippine Islinds.

Mean divergence $10^{\circ}$; length 1.9 inch; breadth .43 inch.

Prirerd abreraxs. Shell ovate or subfusiform: white: longitudinally plicately ribbed; with close-set, well elerated spiral ridges which are entinesas ove: the longitulinal lolls, and are clostly aud 


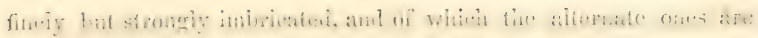
often mueh smaller: apex acute: spire with the outlines almost rectilinear: whorls about seven, quite convex, with a rather deep suture : aperture obovate: lip rather sharp, serrated by the sculpture; labium with a moderate deposit: umbilieus slight. An old shell is sub canaliculate.

Mean divergence $55^{\circ}$; length of spire .26 inch; total length .47 inch; breadth 27 inch. Of another specimen, mean divergence $65^{\circ}$; length .46 inch; breadth .3 inch.

This species resembles Hurex costelleris Lam., the Purpura costelleris of Recve.

Coxus ARurlatus. Shell oborate-conic; attenuated anteriorly: white, with small orange brown square spots, which are more or less confluent transversely, anteriorly and within the aperture of a pale

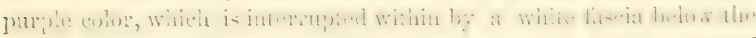
middle of the shell: solid, with finc revolving strie on the spire, and on the last whorl with very regular spiral rather distant minute granulous elevated lines, 1. hich, from the angle above nearly to the anterior extremity, resemble fine strings of beads, but anteriorly are crowded, smaller, and are irregularly and feebly granulons: apex acute: spire with the outlines a little concuve : whorls nearly seven, not coronated: aperture rather open.

Mean divergence $90^{\circ}$; length of spire .2 inch; total length .59 inch; breadth .32 inch.

Tritox pArves. Shell elongate, subfusiform: lingy white on the spire with irregular pale brown stains, on the last whorl pale brown, with two revolving whitish stripes of which the upper one is linear; sometimes the shell is wholly brown except the lower fascia: with longitudinal narrow rounded ribz, of which there are 10 or 12 on each whorl including the raries, which are not easily distinguished from the ribs, and which are distant a little more than a semi-revolution; with numerous spiral unequal elevated lines, which are continuous over the ribs, and of which the anterior ones are larger and granose: apex acute: spire with slightly convex outlines: whorls

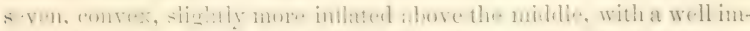

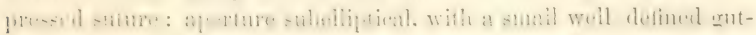
ter posteriorly: labrum crenulate within: labium a little thickened: canal short, wide, a little recurved : with an umbilical indentation.

Miean divergence $35^{\circ}$; length of spire .25 inch; total length .47 inch; breadth .21 inch.

This specics was describud in MLs, hre years since, but being in- 
formed that it was identieal with $T$. angututus Teeve, I suppressed the description. It proves to be quite difierent.

Triton pulcielces. Shell fusiform: reddish at the apex, pale yellow, with spiral unequal bands of gray, of which there are two on the whorls of the spire and two more on the last whorl: with the aperture more or less orange renl : decussate with many small unequal longitudinal and spiral rilteres, with unerual notuluus intersections; varices five, last one very large: apex acute: sprire with the outlines nearly rectilinear between the varices: whorls ciglit, rather convex, subangular at or a little above the midhlle, with a well impressed suture: aperture subelliptical, somewhat acuminate at both extrenities: librum grooved within under the last varix, denticulate on both sides of the groove: labium transversely wrinkled: canal moderately bent to the left and upwards.

Mean divergence $45^{\circ}$; length of spire .33 inch : total length .72 inch; breadth .36 inch.

\section{This shell resembles a small and slender T. chrysostoma.}

Murex mtermenics. Shell elongated, ovate fusiform: whitish, with dingy lrown spots behind the varices, and a few dark brown spiral lines within the aperture, and spots of the same on the labrum: with six variecs on each whorl; with imbricate spiral stria? with strongly crenulated spiral very prominent ridges, which are slightly fringed in crossing the varices, and of which the upper two are approximate, and the next lower one is small : apex acute: spire with morlerately conrex outlines: whorls eight, very angular above the middle, and concave abore the angle, with a deep suture; last whorl with a broad deep groove anteriorly, which is divided into pits by the varices: aperture oborate: canal rather short but white.

Mean divergence $43^{\circ}$; length of spire .46 inch; total length .85 inch; breadth .4 inch.

This species is similar to M. erosus Brod. and .7T. alecutus $T r$.

Murex pauperculus. Shell elongated, obliquely subfusiform: whitish, within the aperture yellowish: with three not very stout varices on each whorl, and slender intermediary varicoill ridges; with a few distant spiral ridges, the intersections being nolulons : apex subacute: spire with the outlines a little convex: whorls six, quite convex, with a deep suture: aperture elliptical: canal short, rather wide and recurved.

Mean divergence $42^{\circ}$; length of spire . .3 inch; total length .71 inch; breadth .3 inch.

Fusus nitess. Shell ovate fusiform: white, with a spiral series, 
of more or less waved trainsversely much elongated spots of brown; on the last whorl are two more series of shorter spots of the same color: with a varicoid rib a little behind the labrum; with rather coarse revolving stria anteriorly ; otherwise smooth and slining : apex acute: spire with the ontlines slightly convex : whorls eight or nine, modarately convex: aperture rather long, subelliptical, acute above : labrum sharp : canal very short, and very wide.

Mean divergenee $: 38^{2}$; length of spire .29 inch; total length .57 inch; breadth .24 inch.

Pletrotoma aliarsti. Shell long ovate-fusiform: bright red, whitish on the folds and anteriorly, with a wide or sometimes a linear spiral hand of brown, which is intermpted by the rils: with nine broat longitudinal ribs on eath whorl: apex obtuse: spire with the outlines nearly rectilinear: whorls six and one-lialf, a little convex, with a lightly impressed suture : aperture obovate: sinus shallow: canal very short, wide, and strong.

Mean divergence $30^{2}$; length of spire .48 inch; total length .74 inch; breadth .27 inch.

l'cezrotoma mraxa. Shell clavate-pyramidal: black, with a broad spiral pale yellowish nodiferous band, and another of the same color anteriorly: with a series of broul close-set smooth not prominent nodules on the lower half of the whorls of the spire; anteriorly with four or five distant raised revolving lines, which are sometimes grmulous, the gramules being white: apex acute: spire with the outlines nearly rectilinear: whorls eight, planulate above the serie's of notules, with a lightly inupresed suture ; last whorl suhangular: aperture small: sinus a little below the extremity of the latbrum : canal very short.

Mean dirergence $30^{\circ}$; length of spire .31 inch; total length .5 inch; breadth .24 inch.

This species resembles $P$. zebru $K r$, for which it was for some time mistaken.

Plecrotoma solima. Shell elavate pyramidal: rery dark lown or nearly black, with the intercostal spacess pale lrown : with a very slight keel on the upuer part of the whorls, and a smooth space below it, and somewhat oh!inge transerse ribs ahruptly commeneing above the mindle of the wherls, and spiral stria in the interenstal spaces; anteriorly with prominent ratised revolving lines deeusating the transverse ribs: apex subatute: spire with the outlines nearly rectilinear: whorls eight, a little convex, with a moterately impres- 
sed suture, which is eremulated by the entrance of the ribs find: above: aperture rather mall : lahrmm probluecel along the mibile

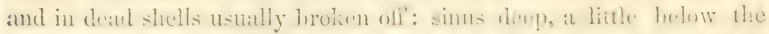

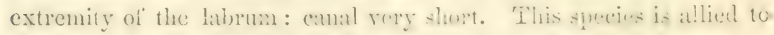
$P$. unicolor Sonvb., P. mustica Souvb., and $P$. fuscescens Gray.

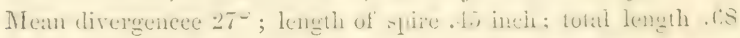
inch; breadth .28 inch.

Pleurotoma fuscocrncta. Shell clavate pyramidal: pale yellowisle white, wiils a summal line of hown, anterionly wax yoilow with revolving lines of yellowish white: with a spiral series of large smooth well rounded nodules, on slightly elevated wide rilges on the lower half of the whorls; anteriorly with a few spiral raiscd lines: apex acute: spire with the outlines rectilineal: whorls seven or cirht, not convex, with the suture not impressed: aperture rather wille: canal very short.

Mean divergence $3:)^{\circ}$; length of spire .17 inch; total length .27 inch; breadth .13 inch.

Pledrotoma maculata. Shell orate-fusiform: white with a spiral series of large thistant fellowish hown sots on the mpere latet of the whorls; auteriurly with a spiral band of very pals yellowish brom terminating ofien in a decpere p pot on the labrum: with cheven or twelve transwerse ridges on each whorl, which are decussated by several spiral prominent lines: apex acute: spire with the outlines

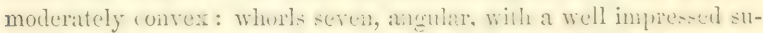
ture: aperture small, nearly in the form of a $\oint$ : labrum well excurved, denticulate within: sinus not very small, near the nulue cxtremity of the labrum: canal short, turning to the left.

Mean divergence $31^{\circ}$; length of sire .1 inch; total length .17 inch; breadth.os inch.

This species has some resemblance to $P$. quadrata $R v$.

Penrotoma qualrata (?) Rle. The tignte of this squecies in Recre's Conch. Icon. represents quite aceurately a species, which inhothits Jatmaica, hut the figure is three times the linme dimensions of our shetl, although it is not said to be magnilime. If our specimens heing to a distinct species, it may receive the name of $P$. Dimixuts.

Pleurotoma decorata. Shell ovate-fusiform: corered, on a whitish gromul, with a net work of bright brown irreglar spots and lines, which on the upler whorls are le-s numerous, smewh wat resular and darker: with, on the uplex whorls, strong transicrse ritges which become smaller and at length disaplear on the pente whorl; 
a ih very dosc-scet rather coarse spiral stria, which are clocantly iliencated on the lower whork ly exeresively ninute lines of growth: apex acute: spire with moderately consex outlines: whorls seven or cipht, ratherenvex, with a well impresonl suture: aperture lares: lahrum well excurvot and protucerl in its lower hatl: sinus rather ileep at the upuer extremity of the labrum: canal short and very wide.

Mean diveremee $: 22^{\circ}$; length of spire .27 inch; total length .5.j inch; breadth .2 inch.

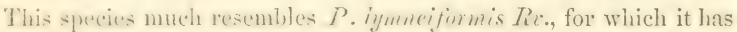
been miztaken. It also closely rescoubles in form, but not in seulp)ture, $P$. patula $R v$.

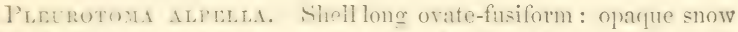

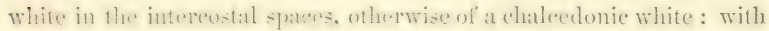

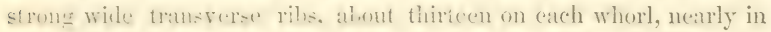
fontinume lines from the summit to the lats whorl, and becoming ob-

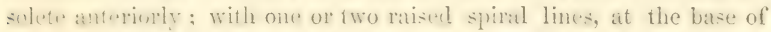
each whorl and numorou- vell rounded revolving rieleses on the auterior latif of the lat whorl: apex acute: spire with slightly convex ontlimes, loner and resulariy conic: whorls seren, slightly ennex, with a molerately impresonl suture: aprerture nearly in the form of a s; latrum driticulatr: within; sintis rather wile and shallow near the upper end of the labrum : canal very short.

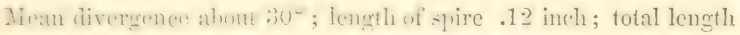
.2 inch; breadth .07 inch.

Pleurotoma pygmina. Shcil orate-fusiform, much elongated: with a hroat irre-gular band of yellowish hrown along the upper part of the whorls and below the middle of the last whorl: with small franclerse afyonsinate ribs, abrot filteen on oarh whorl, and rather

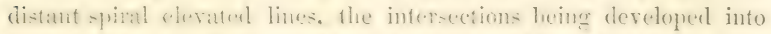

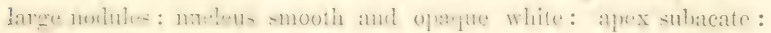

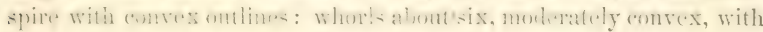
a lightly impressed suture: aperture rather narrow: sinus rather

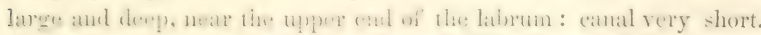

Mean divergence about $30^{\circ}$; length of spire .075 inch; total Iength .15 inch; breadth. 055 inch.

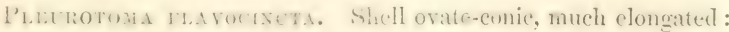
white, with a spiral ham of yollowi-h brown on the upper and on the

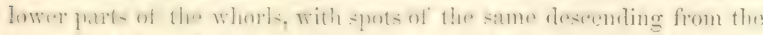
chlere band into the intereostal spaces; with linear bands of the sume 
below the mithle of the last whorl: plicately and transerersly ribled on the midulle of the whorls; with a very broat moderately elevated spiral ridge along the midtle of the whorls; with a slight linear spiral ridge at the summit of the whorls, and a third spiral ridge of intermesliate size at the lower part of the whorls : apex subacate: spire with the outlines nearly rectilinear: whorls about seven, scarcely convex, with an indistinet suture: aperture small, but rather wide: sinus moderate, near the upper end of the lal)rum : canal rery short.

Mean divergence about $28^{\circ}$; length of spire .11 inch; total length .19 inch; breadth .07 inch.

Plecrotona nodata. Shell fusiform, elongated: brown, with white tubereles: with a spiral series of large obtuse undivided scarcely elongated tubereles, which are comected by a small elevated spiral line; whorls slightly shouldered; anteriorly with a few distant elevated spiral lines: apex acute: spire with the outlines nearly rectilinear: whorls seven, a little convex, with a moderately inpressed suture: aperture rather narrow : sinus rather shallow : canal not very short. This species resembles $P$. albinotuta $R e$, which hats the tubercles divided by a deeply impressed spiral line.

Mean divergence $33^{\circ}$; length of spire 2 inch; total length .31 inch; breadth .1 inch.

Pleurotoma ecadrilineata. Shell clavate-pyramidal: white, with one or two fine spiral lines of brown along the suture, and four similar lines just below the periphery of the last whorl, all of which lines are interrupted by the ribs, and with similar but paler lines at the upper part of the whorls and anteriorly: with obtuse moderately elevated transverse ribs, about eleven on each whorl; with many excessively minute finely gramose spiral elevated lines, which are more conspicuous where colored as above described, and which are obsolete at the summit of the ribs : apex acute: spire with the outlines nearly rectilinear; whorls seren, subangular above the middle, with a well impressed suture: aperture long-ohovate, sulhacuminate at both extremities: labrum well excurved: sinus shallow: canal short.

Iean divergence about $30^{\circ}$; length of spire .12 inch; total length .21 inch; breadth .08 inch.

Plecrotom fesmonus. Shell fusiform: white, with a tinge of brown along the suture and in the interestal spaces: with large obtuse pliciform ribs, about nine on each whorl, and numerous unequal inequidistant spiral raised lines, of which one a little above the pe- 
riphliery of the whorls is much larger. giving a sulangular acpeet to the whorls: apex acute: spire with the outlines nearly rectilinear: whorls five or six, rather convex, with a well impressed suture: aperture long obovate: sinus small : canal wide and short.

Irean divergence $40^{\circ}$. Itength of spire .1 inch; total length . Is inch; breadth .085 inch.

Mangeita densestriata. Shell fusiform: white: with narrow prominent ribs, ten or eleven on each whorl, and crowleni recular excessively fine deep spiral strias, which cover the entire surface and are not intermpted in crossing the ribs: apex acute: spire with rathcr convex outlines: whorls scren, suhangular near the smmit, with at rather deep suture : last whorl long, and graduably attenuated into a wide canal.

Mean divergence 4$)^{2}$; length of spire .13 inch; total length .2 .5 inch; breadth .11 inch.

Miaxiegra mericones. Shell fusiform and slenter: pure white: with six narrow subacute prominent rils on each whorl, which are sinuated posteriorly on the right sicle. and which are continuous along the spire like a Murex ; with very numerous microscopie spiral stria in the intercostal spaces: apex acute: spire with the outlines netrly rectilinear: whorls six, slightly convex, with a lightly impresserl suture: last whorl gradually attenuated below into a wide canal.

Mean divergence 32.0 ; length of spire .09 inch; total length .18 inch; breadth .07 inch.

Mragetua riconed. Shell hiconic: whitish, with a narrow spiral hand of brown at the summit of the whorls, which is darker between the rils, and a similar wider hand a little anterior to the periphery of the late whorl; (or some specimens may be described as pale brown, with a spimal hame of white on the periphery of the whorls, and as white anteriorly) : with strong transverse rounded ribs, about nine on each whorl, and excessively fine spiral rather distant raised lines, which are obsolete on the summits of the ribs: apex acute: spire with the outlines netrly rectilinear: whorls six, subungular, with a moderately impressed suture: aperture narrow : labrum often much thickened by the last rib: sinus near the upper extenity of the labrum, rather large in old shells : canal short.

Mean divergence $45^{\circ}$; length of spire os inch ; total length .18 inch; breadth .09 inch.

Var. alba, entirely" of a pure white color.

This species resembles $P^{\prime}$. symmetrica $R i$. and IIungelia Dysuni $R$ ?: 


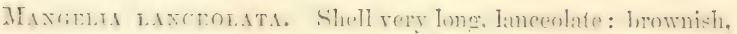

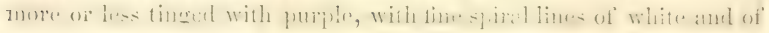
dark brown, which are more conspicuous on the ribs; with a darker and wider brown line along the suture: with six very prominent acute transverse ribs on each whorl, which are nearly or quite continuous on the successive whorls; with a spiral elevated line, on the

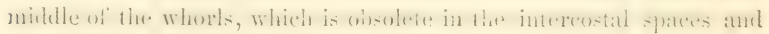
has nodulous intersections with the ribs: apex acute: spire with rectilinear outlines: whorls eight, scarcely convex, with a lightly im-

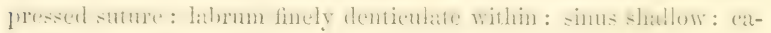
nal not very short.

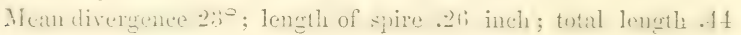
inch; breadth. 14 inch.

Mangelid Crassicostata. Shell subfusiform: dark reddish brown, paler about the apex : with very strong and very prominent transverse ribs, smooth on the summits, about ten on each whorl,

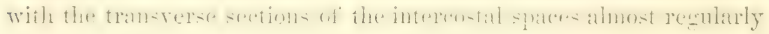
concave; with a few distant elevated spiral lines, of which one is on the middle of each whorl, and one is on the lower half, and the rest are anterior: apex acute: spire with quite convex outlines: whorls about seven, rather convex, with a well impressed suture: aperture narrow : labrun much thickened by the lit-t rib: sinus rather large and deep : canal rery short.

Mean divergence $42^{\circ}$; length of spire .13 inch; total length .22 inch; breadth .1 inch.

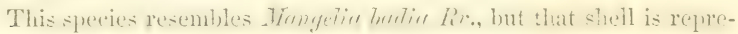
scnterl with a smaller spire and more sleneler ribs. It may posibly be a variety of $\lambda I$. fusca $A d$.

MAangelia Brevis. Shell short, fusiform, orange or wax yellow, white along the upper part of the whorls and anteriorly: with very strong transverse ribs, about nine on each whorl, smooth on the sum-

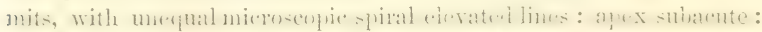

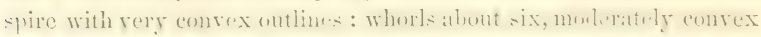
or subangular, with a lightly inyresect suture: aproture quite narrow : labrum much thickened by the last rib: sinus rather large: eanal very short.

Mean diverene about $45^{\circ}$; lingth of spire .14i. inch ; total length .135 inch; breadth .07 inch.

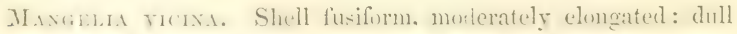
brownish red, white along the upper part of the whorls and anteriorly: 


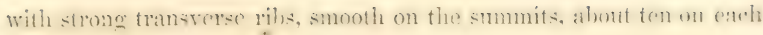
whorl; with unequal spiral microscopic stria: apex acute: spire with rather convex outlines: whorls about six, moderately convex, with at distinct suture: aperture rather narrow: labrum well thickened by the last rib: sinus rather large: canal very short. Similar to $M$. brevis.

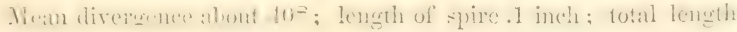
.17 inch; brealth .08 inch.

ScAldriA IIGATA. Shell rather short, conic: white: varices

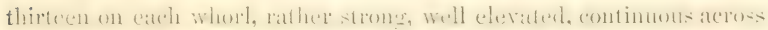
the suture and hut -lightly depresed by it: whorls live or six, scatredy

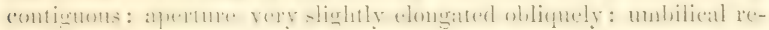
gion with a small ridge parallel with the labium.

Mean divergence nearly $50^{\circ}$; length of spire .15 inch; total length .25 inch; breadth .14 inch.

PHASIAXELAd AFFinis. Shell ovate: with waving or zigzag transverse flames of brown or red; and very numerous minute well defined dots of red or brown, with white shadows on their right side, somewhat in irregular waving or zigzag series, on a whitish ground: apex acute: spire with moderately convex outlines: whorls nearly

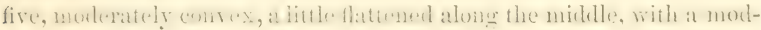

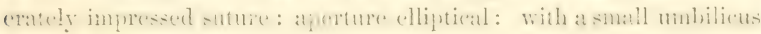
and groove issuing from it, which are sometimes concealed by the labial deposit. This species was at first mistaken for $P$. pulla.

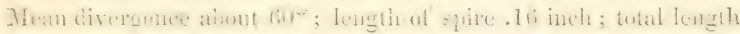
.31 inch; breadth .19 inch.

Punsinella reneris. Shell subglobose: with a whitish ground and large spots of red on the upper part of the whorls; pale red on the antevior and mialle of the last whorl; with well detimed spots of

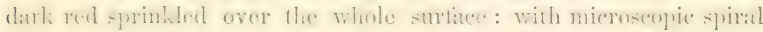
strix on the upper whorls, otherwise smooth: apex rather obtuse: spire with very comves onliges: whorls ahout linur, very convex, with

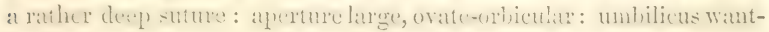
ing.

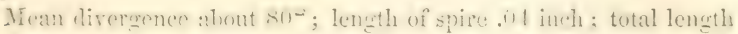
.1 inch; breadth .085 inch.

Phastanelda tesselata. Shell orate conic: with fine rather

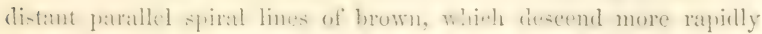
than the whorls; with transverse irregular flames of olive hrown or rest, which have white -hatow: on the leti side, and which form with 
the spiral lines a rather irreqularly tesscllated arrangement of colors : strfice very ghlost : apex subatute: spire with slightly convex ontlines whorls four, molerately convex, whih a well impresed suture; lat: whori abmply rounded or subangular : aperture ovate-elliptical: with a small umbiliens. A variety lrom some other West Intian island is of a nearly olire brown, but without any difference in the spiral lines of dark brown, which do not appear to be subject to the variability of coloring which is so common in this genus.

Mean divergence about $68^{\circ}$; length of spire .11 inch; total length .2 inch; breadth .15 inch.

Prasianela concolor. Shell rather long orate-conic: of a uniform glussy brown, rarely with a sutural bamel of a deeper shade of the same: surface highly polished: apex rather obtuse: spire with the outlines nearly rectilinear: whorls five, rather consex, with a well impressed suture; last whor! subangular: aperture orate: labium with a thick deposit: with an umbilical indentation.

Mean divergence ahout $3 j^{\circ}$; length of spire .0J inch ; total length .1 inch ; breadth .06 inch.

\section{[To be Continued.]}

"Contrinutroxs to Coxchologr" are issued by the subscriber, at irregular intervals of time, in numbers of 16 or $20 \mathrm{pp}$. each.

They are devoted chiefly to a description of new species of the shells of Jamaica, preliminary to a monograph of the shells of that island : but any additions to conchology or malacology come within their plan.

Copies will hereafter be furnished only to subseribers, at one dollar for five numbers, or in returu for books, pamphlets, or specimens presented to the Zoological department in Amherst Col!ege, or to public institutions which have once acknowledged the receipt of a copy.

nG The shells, which were collected in my last expedition to Jamaica, belong to the Zoological Museum of Amherst College. The Trustees of the College have directed the sale of a part of the duplicates. Suites, either of all or of one or more genera of the land and fresh-water shells, will be furnished at 30 cents per species: or selections may be made at a fixed price for each species, and the remainder returned. The marine shells will be furnished at 25 cents per species, without distinction except, in favor of priority of application. A catalogue of all the marine species will soon be published.

25 cents per species will also be paid for any number of authentically named shells, which are not iu the Zool. Mlus. of this college.

The species of Jimaica shells may also be had on exckange, provided that a list of the species, which ean be furnished by any correspondent, shall be first communicated to the subseriber for selection of desiderata, for which only will a return be made. Parcels sent without regard to this rule will be considered as donations to the Muscum, and may be sent, if through New York City, to care of J. H. Redfield, Esq., 82 Courtland Strect, New York. If not through New York, they may come by express, via Northampton, Mass.

$$
\text { C. B. ADAMS, Aunerst, Mass. }
$$




\title{
CONTRIBUTIONS TO CONCIIOLOGY.
}

\author{
NO 5.
}

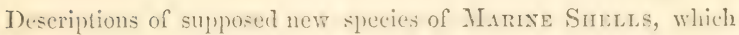
inhabit Jamaica. Tiy C. I3. Adams, 1850. Continued from 1). (is.s.

Pimastanella concrnas. Shell broad ovate, or orate conic:

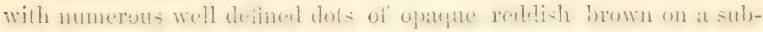
transparent ground of very pale red or brown, the dots being less numerous and less uniformly sprinkled on the upper part of the whorls: surfiace weil polishent: apes rather obtuse: spire with quite convex outlines: whorls four, quite convex, with a well impressed suture: aperture ovate-orbicular, with its plane very oblique to the axis of the shell : hathun mucit curvenl: with an umbilical groove parallel to the labrum.

Mean clivergence about $60^{\circ}$; length of spire .07 inch; total lengtl .14 inch; breadth .1 inch.

Trocins Pulcirer. Shell conical, much elerated: pale claret color, with a dark hrown alpex, and latre ill delined frot of white; with spiral serins of minute latrk rect whloug spots, which are froportioned to the size of the spiral ridges on which they are placed; the ridges of least size are not spotted: solicl, with ten or twelve minute

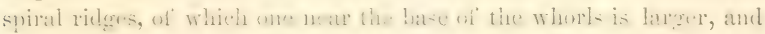
three are of an intermediate size, viz., one on each side of the suture and one on the middle of the whorls; on the lower side of the last

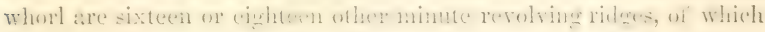
every second or third is spotted : apex acute : spire with the outlines

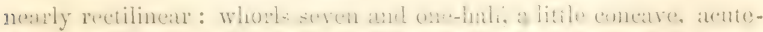
1y prominent in the lower part; lat whol stimangular, molerately

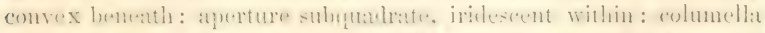
subtruncate: umbilent wanting. The vhorls in this shell have the same form at in 7 . jinjerines, and the general ferm of the shell is like that of $T$. pyramidatus.

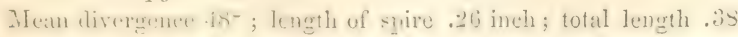
inch; breadth .27 inch. 
Crngula (?) concinva. Shell brondly ovate-conic: subtransparent, wax hrown, darker at the sutumal rifige : smooth and shining ; at the summit of the whorls with a narrow ridge searcely elevated, but separated hy an impesend lime: apex rather olutuse: spire with the outlines moderately convex: whorls five, quite convex, with a well impressed suture; last whorl large: aperture acute above, in the rest regularly orate: lip a litule refitecterl on the left side: umbilical region slightly indented.

Mean divergence is:- $)^{-}$length of spire . (1): inch ; total length .07.) inch; breadth .055 inch.

Cingula (?) solida. Shell subconic, woll elevated: dark brown, with the lip amb apex white: with a few distant sulgramular elevated spiral lines, of which the alternate ones are much more minute; anteriorly smooth : anex obtuse: spire with the outlines nearly rectilinear: whorls five, slightly shouldered alove, searcely convex, with a well injeresed suture: aperture onlicular, parallel with the axis of the spire: lip reflected on the lett sith and on the anjacent part of the anterior side : umbilical region moderately indented.

MLean divergence aljout .3.\%; fength of spire .11.) inch ; total length .085 inch; breadth .045 inch.

Ciscitul (?) coxic.s. Shell clongated, eonic: whitish, with large irremalar spots of wax color, and a wax-culored summit : solil, with three or four slightly elevated obtuse spiral ridges, and alout the periphery of the last whorl two or three more, all of which are slightly striaterl across; on the luwer wherls with nearly obsolete hroad xidges; anteriorly smooth: apex acute: spire with rectilinear outlines: whorls six and one-halt, llat, with a lightly impressed suture; last whorl with a moderately acute periphery: aperture between (qualiate and orbicular, nearly parallel with the axis of the spire: lip reflected on the left site and on the aljacent part of the anterior side : umbilical region moderately indented.

Ifen divergence ahout $32.2=$; length of spire . (16.) inch ; total length .105 inch; breadth .06 inch.

These last three species we have refirmed, with some doubt, to Cingula of loleming, restrieting this gants to the section in which the labrum is not thickened and the apreture is 'Turbinotid, and excluding

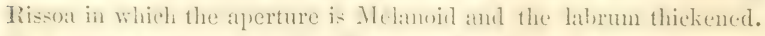
C. concinna howerer is with diviculty referred to the same generic type with ('. sulidla and C'. eonien, being eminently distinguished by its smouthess and translucency, (in this respect resembling, as also 
in color, P'upa orata, I'. milium, s.e.) aml its broadly orate form clecantly rombed below and acute alowe, with the sume batutiful outline repeated in the aperture, as in some Phatianellate. The last two species have a striking coincidence in the general plan of sculpture, reflection of the left side of the lip, ce.e, and evidently betome to at restrieted natural gromp, which perhaps should he separated from ('ing la. We have been unable to obtain more than one specimen of each of these species.

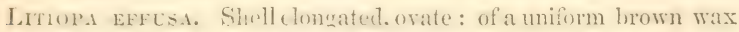
color, subtransprent : apes uhtuse : spire with the outlines rery conrex above, nearly rectilinear in the rest: whorls six, quite convex, with a well impresect suture: apperture ovate, antribrly produced so as to reemble a very hroad short canal: lahrum thin, not very sharp, somewhat reflected: columella slightly twisted.

Mean elivergence about :i, ; ; length of spire of inch; total length .11 inch; breadth .06 inch.

Litiopa obesa. Shell ovate: of a uniform brown wax color, subtranspartnt: smonh : apex vituse: spire with the outlines moderately convex: whorls fire, rather convex, with a distinct suture; last whorl large: aperture large, oblingely subrhomboilal, ethuse, lout seareely proflued anteriorly: lahrum very thin, xetreating abore, scarcely reflected: columella slightly arcuate.

Mean divergence alhont .i.); length of spire .08 inch; total length .185 inch; breadth .11 inch.

Littorina Jamaicensis. Shell oblong conic: with transverse somewhat oblique flames of rusty brown or slate color or black, on a white erromel, which are intermitent on the midnte of the wher's hy a spiral slate-colored or black band, which is of unequal width in

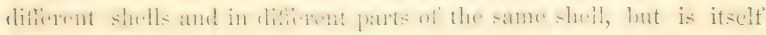

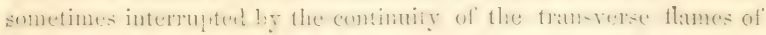
white and slate eolur ; hown on the colusallat ; hownish black within, with at spiral hand of white near the anterior extremity : solicl, with very deep rather distant spiral stries of which there are about eiolit on the pendt whorl, and wheh are more crowled anteriorly : apex

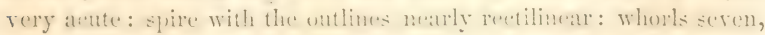
convex, with a lightly impessent sume; last whesl with an angular and subcaribated periphery : aperture rather lavoully ovate: collumella areuate and ilattencel. The sulphere of this shell is like that of L. carinata Orb. and the form is like that of $L$. lineata Orb. ( $L$. ziczuc Desh. ot al ) but is rather more rolust, and the shell is more 
solirl. A ravicy of coloring lats all the sheli black exeept on the upper third of the whorls and on the anterior part. A variety of sculputue and eoloring las the stria enlareal warly to the wilth of the intervening rideres, and is mo-ily black with spirally elongated spots of white on the ridges.

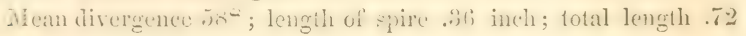
inch; breadth .44 inch.

CinensitziA LAtior. Shell moderately elongated: white: with about twenty to twenty-four prominent transterec ribs, the rnds of which mostly alternate at the suture, and which are produced on the last whorl into the umbilical indentation: with numerous crowded spiral stria', which asecend the sires of the rihs without being pronlueed orer their smumits: nuchas conising of about one smooth globular whorl, with its axis aurly at right angles to the axis of the shell: spire with the outlines a little convex: whorls about nine after the loss of the nuchens, whing convex, with a citstinet suture: aperture obliquely orate, acuminate abuve: labim much thickencel : umbilical region moderately indented.

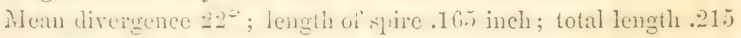
inch; breadth .065 inch.

Crennitzin puncta. Shell much elongated: white: with about trenty-six to thirty 'rather prominent transcerse ribs, which are not produced below the convexity of the last whorl; with numerous crowded spiral strix in the intercostal spaces, one of which strix, a little above the mildile of the whorls, ame another along the suture are wite ant deep, rosmbling spiral series of punctures; intereostal spaces depresed antriorly beluw the aljacent anterior surface : spire with the outlines rectilinear: whorls ten or eleven, after the loss of the nucleus, scarcely convox, with a distinct suture : aperture oraterhombic: labium sciuredy thichoned: mubitical region scarcely indented.

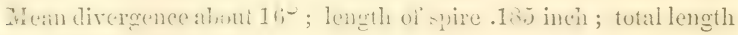
.22 inch; breadth .05 inch.

Cineminzia obeliscus. Shell much elongated: white: with twenty-six to thirty transverse prominent ribs, which are not produced below the convexity of the last whorl; with numerons crowded

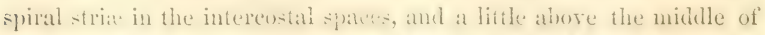

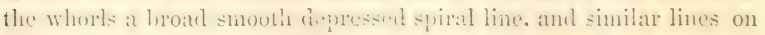
the middle and anterior of the last whorl: spire with the outlines rectilinear: whurls elercn after the loss of the nucleus, planulate, 


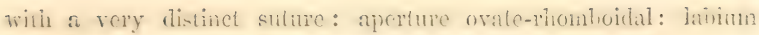
slightly thickened: umbilieal region not indented.

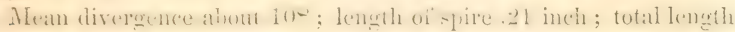
.25 inch; breadth ..05 inch,

Cirennitzis subulata. Shell much elongated, subulate: white, or pale brownish white with two spiral bands of pale wax color, and a thire of ihe same color anteriorly: whth about twonty-eigit to thing

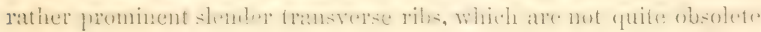
below the convexity of the last whorl; in the intercostal spaces and anteriorly with numerous excessively fine crowded spiral strice, of

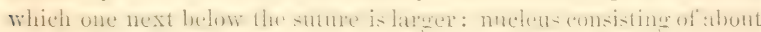
one and onc-half whorls. morterately oblinue: spime with a slightsly curved axis, with the outlines scarcely conrex: whorls ten after the loss of the nucleus, rather convex, with a well impressed suture: aperture ovate, acute above: labium slightly thickened: umbilical region slightly indented.

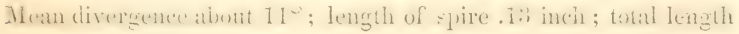
.17 inch; breadth .045 inch.

Chemitzis Levis. Shell much elongated: white: with about twenty-eight to thirty transrerse rather stont ribs, which are not produced below the convexity of the last whorl; without spiral strie; with the intereostal spaces of the las whorl anderionly cheressed below the surface of the amerior region: with sarewly pereentihle lines of growth anteriorly: nucleus consisting of about one and one-third smooth whorls, quite oblique: spire with the outlines nearly rectilinear: whorls nine or ten, searcely convex, a little constricted above:

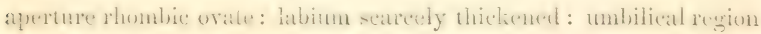
not indented.

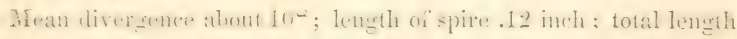
165 inch; breadth .04 inch.

Cinmsitzid substruta. Shell moderately elongated: white, with a slight tinge of wax color next above the suture: with about twenty-two to twenty-four transverse rather stout ribs; in the inter-

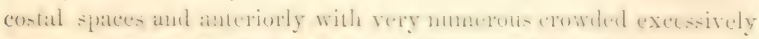
minute spiral strite, which are scarcely pere plihte under a common magnifier; on the middle of the whorls is a spiral series of shallow pits in the intercostal spaces; on the last whorl, with the anterior ex-

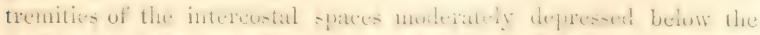

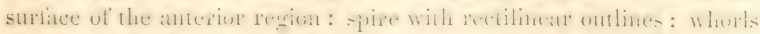
ahout eight, planulate, whit a di-timet stutue: aperture fhoshicorate: labiun scarcely thickened: unbilicul region scarcely indented. 
Mean divergence ahout $12^{\circ}$ : length of spire .09 inch; total length .115 inch; breadth .04 inch.

Chematzia exilis. Shell very slender: white: with about fifteen to eighteen stout transverse ribs, which terminate just below the convexity of the last whorl; with numerous spiral stria in the interco-tal spaces, but not anteriorly; with the intercostal spaces on the lat whorl anteriorly depressed below the aljacent surface of the anterior rewion: nuclens with about one and one-half smooth whorls, nearly at right angles to the rest of the shell: spire with rectilinear outlines: whorls ten besiles the nucleus, planulate, with a moderately impressed suture : aperture rather short, subelliptical : labium scarcely thickened: umbilical region scarcely indented.

Mean divergenee about $10^{-}$; length of spire .145 inch ; total length .165 inch; breadth .037 inch.

Chemnitzia pusilla. Shell very slender: white: with about twelve rather stout transverse ribs, which are not produced below the convexity of the list whorl ; without spiral stria ; with the intercostal spaces on the last whorl depressed anteriorly below the adjacent surface of the anterior region, which is smooth : nucleus consisting of about one and one-half smooth whorls, very oblique: spire with rectilinear outlines: whorls ten or eleven besides the nucleus, moderately convex, with a well impressed suture: aperture orate: labium not pereeptibly thickened: umbilical region scarcely indented. This species resemble $C$. levis.

IIean divergence about $S^{2}$; length of spire .11 inch; total length .135 inch; breadth .03 inch.

Cnemiczia flavociscta. Shell moderately elongated: white, with a broad spiral band of yellowish brown along the suture: with about twenty-eight transverse well rounded ratherslender ribs, which become obsolete on the anterior surface; with excessively minute spiral strix, in the intercostal spaces, coarser and traversing the ribs on the anterior region : nucleus consisting of about one and one-half smooth whorls, very oblique: whorls eight or nine besides the nucleus, slightly convex below the middle, slightly shouldered, with a distinct suture: aperture rather small, elliptical: labium moderately thickened: umbilical region scarcely indented.

Mean divergence about $122^{\circ}$; length of spire .11 inch; total length .145 inch; breadth .04 inch.

Cuemaizia muticostata. Shell moderately elongated: white, or tinged with yellowish brown : with about thirty-four to thirty-eight 
slender transverse ribs, which hecome obsolete on the anterior surface; in the intercostal spaces, with rather coarse distant spiral raised lines, which traverse the ribs only at their anterior extremities on the last whorl: nucleus consisting of little more than one smooth whorl, very oblique: spire with the ontlines slightly convex : whorls nine besides the nucleus, searecly convex, with a well impressed suture: aperture ovate, subacute above: labium slightly thickened: umbilical region scarcely indented.

Mean dirergence ahout $12^{\circ}$; length of spire .125 inch; total length .165 inch: breadth .045 inch.

Cuemsitzi. reticleatu. Shell moderately elongated: white: with about twenty-six to thirty rather strong transverse ribs, which become obsolete on the anterior surface; with very coarse distant spiral ratised lines, decussating the rihs : nucleus consisting of a little more than one smooth whorl, very oblique: spire with the outlines a little convex; whorls about seven besides the nuclens, slightly convex, with a well impressed suture: aperture ovate, acute ahove: lathum scarcely thickened: umbilical region not indented.

Me:m dirergence about $12^{\circ}$; length of spire .09 inch; total length .125 inch; breadth .04 inch.

\section{Note on Pholus corticuriu Sowb. By C. B. Adams, Feb. 1850.}

This species was discovered by me in the bark of a locr, on the shore of the Bay of' Port Royal, near Kingston, Jamaica, in Mareh, 1844. Specimens were distributed with the Mss. name of I'. rosea, subsequently altered to P'. corticaria. Some were sent to the British Mruseum and to Mr. Cuming's collection, where they were seen by Mr. Inanley, who atlirmed them to be not distinet from a variety of $l$. pusillu Linn. In deference to his opinion, the description was suppressed from my 'Synopsis' of new species from Jamaica. In P'art $\mathrm{X}$ of Sowb. Thes. Conclı. (Dec.?) 1849, a description of this species is published for the first time, with the name of ' $\mathrm{P}$ corticaria Ciray, Mss.,' as being in the British Museum, without indieation of habitat. It is said that 'the specimens, having bored in floating mahogany, have taken a reddish color.' This color was derived from the bark of the tree. The shells did not penetrate the wood, and where they were in contact with it, they were distorted, as if unable to penetrate it. 
Mes. names are not queta?, le as having the value conferred by authorship, and the name must stand at above. It is mufortumate that the de-

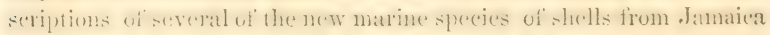

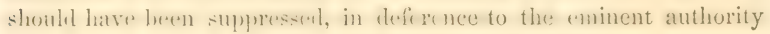
above mentioned, and distributed with erroneous names.

Descriptions of supposed new species and varieties of TERRES-

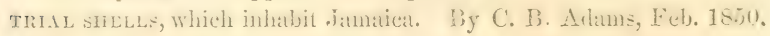

Must of the fo!lowing sinecies have been reecived from the Ifon. Edward Chitty, to whom, on this and on former occasions, I have been greatly indebted for several new species, and especially for information respecting the distribution of the species over this island. For similar favors I am also indebted to the Rev. F. R. Holland and Mrs. Holland, to Miss Agnes Hines, Dr. J. S. Hyde, and to James

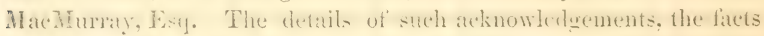
communicated, my own obserrations on the varieties, distribution, habits, \&c. of the species, as well as their synonymy and the correction of errors, are mostly reserved for the monograph to which these papers are preliminary. It is proper to rake this statement here, lest I shoulht appent forgetlin of the kinthess of many friends, who in various ways are aiding me in this work.

Helix ingens. Shell transversely orate, convex above, more convex beneath, concave next the periphery below, and also above exrept in the litst hall of the list whorl: with a rery atute periphery: above redelish hrowin of shades varying in difierent individuals and in difierent parts of the same shell, ustally paler on the last whorl; beneath dark redilish or blackish brown next the periphery, whitish in the rest; lip rethlish brown : sturface strongly gramulatent beneath, exexpt at the margin of the umbiliens; alowe more feebly ramulated, smooth on the upper whorls and on the upper part of the lower whorls: spire convex, moderately elevated : whorls at little more than five, convex next below and concave next above the suture, with a

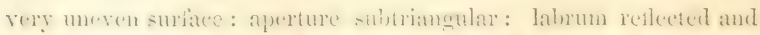

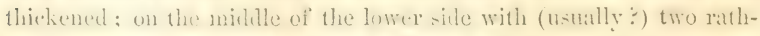
er listant stout teeth, the inner of which is (frequently ?) accomprat nied by a contiguns small tonth: umbiliens large and deep, scarcely contracted except quite near the apes, where it conseguently termi- 


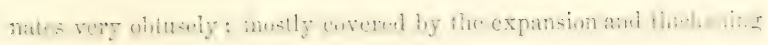
of the lip.

Greatest breadth 2.98 inches; least breadth 2.45 inches; height $1 \cdot 2$ inches.

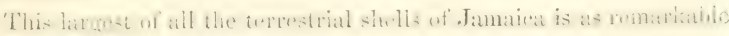
for the character of its umbilicus, as for its magnitude. 'This species is intermeliate between II. patina, Ii. aetita, and H. Aluetuata.

Ifelix valrda. Shell hemispherical above, moderately convex beneath, with a very slight sharp carina on the periphery, which is otherwise well rounded: abore dark reddish brown, often blackish along the suture, paler at the apex, often paler beneath; with a narrow pale band at the periphery; lip brown : surface rather fincly but strongly and densely granulated, except near the apex: spire very convex and much elerated: whorls fire and one-half, quite convex, with a ratler leep suture: aperture much expanded abore and laterally, transwersely aurilorm; with tho lip well reflected and thickened; with four tceth, which are similar to those of $\mathrm{B}$. Bromazi : umbiliens wanting. This shell resembles $H$ simeto in its sculpture and in the white line aud delicate keel along the periphery: in respeet of the teeth it resembles II. Bronnii. Last summer a specimen was loaned to me by Mr. Cuming as H. Bromii. This species differs from both of the above in the much dilated aperture.

Greatest breadth 1.4 inch; least breadth 1.1 inch; height .S inch : of a small varicty; greatest breatth 1.17 inch; leastbrendih. .97 inch; height .73 inch.

IIELr rotis. Shell depressed, suborbicular, subconic, moreratcly convex beneath, with a slight sharp keel along the periphery: (redlish brown?): surfice rather strongly gramulated except on the upper whorls : spire between convex and conic, but little elevated: whorls nearly five and one-half, convex next below the suture, and next above it rery concase, foming a shallow spiral furrom; with the suture lighily impressed: aprerture with the same form and character of lip as in $I I$. simecru; with three robust teeth on the lower side, of which the two on the right have, externally, comespondiug furrows, which are long and deep: umbilicus wanting.

Greatest breadth 1.44 inch; least brendihl 1.19 inch; height . 75 inch.

D.: Mrany gromps in all the principal genera of lank shells in Jamaiea present whenomena precisely similar to the following eximnple, which is now brietly statcd, as an apology for both occasional ex- 
cess and deficiency in describing new spreies. We hope erentually to describe all the kindred fate, which we have observel, since the bave important relations to the general questions of the limits, origin, and permaneney of speries. Sinilat obervations by Mr. Chitty coincile with my own, and are more numerous than my opportunities have permitted me to make.

Almost every one of the numerons districts in Jimaica, which are fatrorable for the terrestrial Mollusen, has one or more peculiar modifications of the tyoe of that (xroup of IIelices, which is represented by HIf simmete. In some instances, these subordinate local types are accompanied hy a type which has a more general distribution. In other cases a local type exists alone.

Some of these local types are so aridely distingnished from the general type, that no one liesitates to regaril them as good species. Such are II. anomala, H. strangulata, and II. tridentina. Less different from the typical species are II. Schroeteri, II. Bromii, II. valida, and II. picturata. Other local types present an inferior quantity, but an almost expul eonstancy, of diaterence from the typical species. In the latter case, he who is not aryutinted with their distribution and has not the means of olserving their constancy, may be confident that such forms are mere varieties. On the other hand, an observer, whose attention should be wholly oceupicel with these phenomena, would be likely to make almost as many species as there are localities.

In some instances the peculiarities of a local type, which differs but slightly from the typical species, are quite constant at the given place, but vary geographically, that is are gradually lost in the more and more distant individuals. I am not aware that these examples are numerous.

Not only does the amount of difference between the loeal types vary from that of well marker sipeeies to that of searcely distinguishable varieties, but the inliviluals of a given locality, while preserving the peculiarities of the type, sometimes difler from each other in characters which appear to be as important, except in the want of constaney, as those which distinguish the local group.

Similar to the above is the case of the Naiadx of the United States, and to a greater or less extent of many tribes of Mollusea in in other willely extended regions. These remarks might be extended to many elisses in other divisions of the animal kinglom; but our object, at present, is merely to notice an example of a class of phe- 
nomena, which are remarkable for being concentrate 1 in great numbers within the narrow limits of Jamaica, instead of being sprearl over a continent or a zone.

Naturalists are well aware of the perplexities, which arise from facts, such as we have now allarled to, in attempting to ascertatin the limits of species. The question-what is a species-is easily answered in theory. But in many elasses of the animal kingelom, this question is extremely perplexing in practice. It is mly the laws of nature which are simple; the resultant effects present a tangled mass of phenomena, which only Infinite Intelligence ean fully comprehend. Many of the dereriptive generalizations of organic nature, like that of lineal gratation, which have so much of beantiful simplicity, have alrearly pasienl away, becanse they originated in the human mind, and formed no part of the Divine plan. Others, like those of the mily of place and patentage in the origin of species, are fast disappearing. Perlatps the theory of distinet limits of species may fail in some of the lower classes of animals

We shall now be molerstout, when we describe the three following types in the group of IIelices above mentionerl, without attempting to decide whether the degree of difterence should elevate them to specific rank, or rerluee them to varieties of Ilelix sinuata. Cnable now to ascertain, with ahsolute certainty, which form was the type of the original deseription by Muiller, we have assumed it to be that which is most generally distributed through the island.

Helix invalidi. Shell very convex above, somewhat flattened below, with a very slight sharp carina on the periphery: dark reddish or blackish brown, paler at the apex (and after exposure, as usual in the group), with a white lip, and a white line along the periphery: surface limely gramulaterl, wxerpt on the upler whorls of the spire and aromel the umbilical rewion: spire much elevated : whorls five, moderately convex, with a lightly impressed suture: aperture like that of II. sinuata, but rather smaller, with the lip and teeth less robust, the right pair of teeth a little more connected at base, and their exierior indentations shorer: mulilicus wanting. This shell is much smaller than the common type of $H$. sinuata.

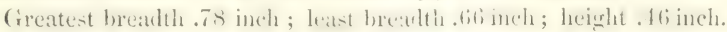

Helix propenuda. Shell like H. sinuata, but the color is very pale, almost white exept on the uplex whorls: the aperture nore contracted ; the exterior furrows ate very short, and the right patr of teeth a little joined at base: the epridermis consists of small distant 


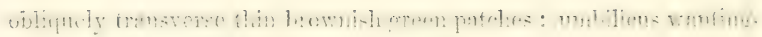

Groatest brealth . 885 inch; least brealth .765 inch; height .5 ineli.

Inem Candescens. Shell like $I I$. invelide, but white or yellomish white, with a line of clearer white along the periphery: sprire much less elevated, and more regulirly convex: surface smooth, or granulated on the last whorl, rarely granulated on the penult whorl: suture well impressed : aperture as in $\mathrm{H}$. invalida, but the lip and tceth are inore robust, and their cxternal furrows are very long and deep : umbilicus wanting.

Greatest breadth .84 inch; least breadth .74 inch; height. 43 inch.

Ilemix Foremaniana. Shell ovoid, with a scureely pereeptible obtuse angle on the periplery: white, with a very pule lorn-colored epidermis: with fine irregular stria of growth, and sometimes on the lower sicte of the last whorl with inequidistant unequal coneentric strie: spire very much elevated, with very convex outlines: whorls seven aml one-half, quite conver, with a well impressed suture; last whorl rery convex beneath to the centre, without any indentation in the umbilical region: aperture obliquely lunate, wider below than abore; within, a little below the middle of the right side, is a long lameliar tooth, commencing aluuptly in the bottom of the aperture, and gradually diminishing in height to its termination a little within the margin; with a wide irregular tooth on the end of the columellat labrum sharp : umbilieus wanting. This species is dedicated to my friend Dr. E. Foreman, of TWashington, who is well known for many years to have rendered valuable services to Conchology.

Greatest breadth .78 inch; least breadth. 73 inch; height. 9 inch.

IlELIX ALveus. Shell semioval, scareely subangnlar on the periphery: whitish, manslneent; with excessively fine unequal striee of growth : spire extremely convex, with a very deep suture; hast whonl rather small: aperture small, subquadrangular: labrum sharp and thin: labium with a distinct but not a thick deposit: umbilicus about half as wide as the last whorl, scarcely contracted except quite near the apex, where it consequently terminates very obtusely.

Greatest breadth .3 inch; least breadth .28 inch; height .18 inch.

Ifexix coltueldatA. Shell convex-conic above, moderately convex beneath: white under a yellowish or greenish brown epidermis : with fine irregular striu of growth; sometimes with numerous microscopic punctures : apex subncute: spire rery much elevated, nearly conic: whorls uearly six, mode rately convex, cbtusely a little shoulder- 
ed, with a deep suture; last whord slightly flationed above the miditle: aperture in the form of a spherical triangle: librum sharp: colitmella much and very obliquely produeed, eurred, very thick, abruphly termimating, opaque white: umbilical region not indentert.-This species has been eonfounded with $H$. teneminu, and distributed as such.

Greatest breadth .63 inch; leust breadth .50 inch; leight .47 inch.

Proserrina discoidea. Shell neilly discoidal: pale yellowish or greenish brown; subtransparent, shining: with excessively tine stria of growth, and an impressed spiral line next below the suture : spire convex, slightly clevated: whorls four and one-lialf, moderately conrex, with a well impressed suture; last whorl a little flattened beneath : aperture much dilated laterally, transwersely ovate, but much modified by the penult whorl, witlout teeth: labrum thin and sharp: central callus occupying the region of the umbilical indentation : umbilicus narrow and deep. - 'This species is nearly atlied to $P$. operlines.

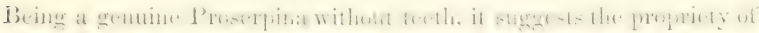

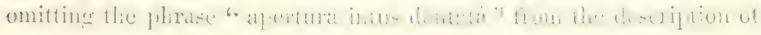
the genus.

Greatest breadth .275 inch; Ieast breadth .23 inch; leight .09 inch.

Proserpiya purcmra. Shell similar to $P$. mitide, but much smaller and less discoidal, the slire being more elevated and the last whorl higher: the color of the upper whorls, (the last and usually a small part only of the penult whorl being excepted), varies from a deep erimson to a bright orange red, with an opacune white line along the suture. In all other characters this shell so elosely resembles 1 '. nitida, that I have long hesitated whether I should propose it as a distinct species. The peculiarity of form appears to be allsolutely constant in the individuals (about 30), that I have scen: that of color fails partially only in a very few, which appear to have been bleached by exposure.

Greatest breadth .2 inch; least breadth .18 inch; height .12 inch. Proserina midextata. 'This shcll is also rery similar to $P$. nitide, but is much smallex: besides the deep spiral line which accompanies the suture, there are several other very feebly impressed spiral lines; the surface is not so smooth although equally brilliant: the color is yellowish greon: the aperture has only two teeth, one near the base of columella, and another a little above it. Specimens 
of $P$. millira, of the same size, have five teeth well developed, as have also the least of our specimens of $P$. nitida.

Greatest breadih .21 inch; least breadth .13 inch; height .08 inch.

Crundela Greyara. Shell much elongated, tapering quite uniformly to the apex: dingy white: with excessively elevated lamellar transverse ribs, of which there are six on each whorl; with the intercostal spatees densely cosered with microscopic spiral stria: spire with the ontlies nearly rectilinear : apex broadly truncate with the loss of five whorls, of which the first one and one-half are smooth, the next one is elosely covered with microseopic transwerse raised lines, and the rest have twelve to fourteen lamellar transverse ribs, which are molerately elevated, but which increase in size and diminish in number down the spire to a little below the place of truncation: remaining whorls about seven, somewhat flatteneel, with a very deep suture; last whorl small, scarcely protuced from its last point of contact with the penult whorl: aperture obliquely ovate, a little modical by the penult whorl : labrum near the last rib, very thin and sharp, not reflected.

Length . 31 inch; breadth .14 inch.

This extraordinary shell is dedicated to IIis Exeellency, Sir Charles Girey, the present Governor General of Jamaica, as a tribute of respect for those attainments in Natural Science, which atorn a high oflicial station. We thus also commcmorate the adninistration, during which a very large portion of the land and fresh-water shells of Jamaica have been discovered.

Cylindrella lata. Shell very robust, cylindrical in the lower three-fourthe, rapilly tipering above: wax color, with a dark brown line next below the suture: with excessively minute crowded transverse strix; anterior spiral keel very prominent: apex not very broadly truncate, with the loss of —— whorls: whorls remaining eight and one-third, very narrow, slightly convex, with a lightly inpressed suture: aperture consilerably produced beyond the penult whorl, transversely elliptical: lip broanly reflected. This species in sereral reperets combines the characters of $C$. senguinen and $C$. rosece.

Length .86 inch; breadth .33 inch.

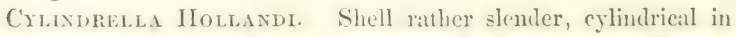
the lower thee fourths, slowly tapering above: wax color: with rery minute crowled transverse stria, and the anterior spiral keel not very prosninent: apex rather broadiy trumeate, with the loss of - 
whorls: whor's remaining ten, sulpplanulate, with a woll impresend suture: aperture consilerably produced beyom the penult whenl, between orbieular and trapezoidal, slightly eftise ly the amal within the anterior keel; lip well expanded, moderately reflected.

Length .82 inch; breadth .18 inch.

Crumdrelda Augusta. Shell not very slender, cylindrical in the lower three-fourths, slightly tapering above: pale wax color: with very minute crowded transverse stria ; anterior spiral keel not very prominent : apex broadly truncate, with the loss of __ whorls; whorls remaining nine, a little convex, with a woll impresend suture: aperture moderately producerl begond the pemult whorl, sulorbicular, a little dilated at the left of the upper sidr: lip well expanded, moderately reflected. This species is allied to the preceding and to $Z$ : montana.

Length .65 inch; breadth .17 inch.

Acnatr.a Buandixa. Shell regularly conic, but very sleniler: very pale brown or horn color, with very dark brown transverse broal bent stripes, about three on sarh whorl, less distinct on the upper whorls, and wanting on the nuclear whorls: with rather fine regular transverse stria; rather thickly and very fincly eremulated at the upper margin of the whorls: apex moderately olituse, smooth on the first whorl : spire very long, with the outlines rectilinear : whorls nine, molerately eonvex, slightly and acutely shouldered above, with a well impressed suture: aperture rather long-ovate, small: labrum sharp, very thin: columella nearly straight. This species is most nearly allied to $A$. propinque.

Mean divergence ahout $16^{\circ}$; length .6.2 inch; breadth .135 inch; length of aperture .16 inch.

Acmatixi rexus. Shell ovate fusiform, much elongated: subtransparent, pale brownish yellow, with brown transverse stripes, which re very narrow exerpt at their summits, where they are nuch dilated and are very deeply colored; there are on each whorl four or five of these stripes exeept near the apex : varicose coincidently with the brown stripes; with rather fune regulat transverse stria: apex rather obtuse, with rather more than one whorl smooth: spire rather long, with the ontlines a little curvilinear: whorls eirht, moleritely convex, with a well inpressed suture: aperture rather long ovate, narrow and very acute above: labrum sharp and thin: columella nearly straight, but little truncated. 
MIean direrrence about $19^{\circ}$; longth . 53 inch; breadth .125 inch; length of aperture .17 inch.

Acmitixa perplexi. Shell orate-fusiform, much elongated: almost trunsparent, pale yellowish brown, with transverse moderately curved lines of dark brown, of which the last color's the labrum, three to four on each whorl, wanting on the upper whorls, and scarcely perceptible at and above the middle of the spire: with fine not crowded transverse strix; lines, which indieate the varices that are coincident with the brown stripes, scareely distinguishable from the strix: apex subaente, with nearly one and one-half smooth whorls : spire much elongated, with the outlines moderately curvilinear: whorls about six and one-half, moderately convex, with a well impressed suture : aperture long, orate, quite narrow and acute above: columella a little twisted scarcely truncate. This species elosely resembles $A$. propinque, but the strie are finer and more distant, and the outlines of the spire are more curvilinear. It attains ahout one-half of the size of that shell.

Wean diverence ahout $21^{2}$; length .33 inch; breadth .09 inch; length of ajorture .12 inch.

\section{ITO BE CONTINOED.]}

Through the the lindness of my fivend $T$. Bland, Esq., of Jamaica, I have been able to rerify Ir. Chity's obserwations on the opereuimm of Geomelamia. It has a latemal apex, with one and one-hulf inner wholls (in G. expansa), and many fine inequidistant strix on the last whorl, which is otherwise smooth and shining.

Cyclostoma aculeosum (p. 2 of this work) is probably a variety of C. IIillianum, with a more elerated spires. It is difieult to fix a limit in their gradual passuge into eatch other.

The rext No. will contain species of Crelustoma in continuation of the above; also descriptions of new land shells of Jamaica, which have just been reecived from 'T. Bland, Esq., to whose industry and generosity I have been much indetted on various ocensions: —also the synonymy of ledix picturate; and more new marine shells of damaicas.

Eels, I 185 ), 


\title{
CONTRIBUTIONS TO CONCIIOLOGY.
}

\author{
NO 6.
}

\author{
Remarks on the origin of the Terrestrial MLoluescs \\ of Jamatca. By C. B. Adans. March. 1850.
}

Srsce the publintion of the rematks on the distribution and differemees of the types of the Terrestrial Morluses of Jamaica, ats illus-

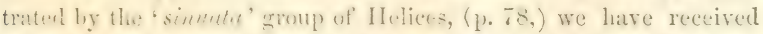

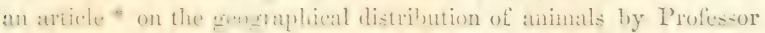
Agassiz. In this aricle a similar statement is made respecting the di-tribution of the diflerent tryes of hons. This ate differs from that of the Itelices atwore-named, inasmuch as there is no dilliculty in Wh thing the speeies, heramse the difit renee between the specifie type and the types of it congmers is much greater than between the subtypes comprehentinl within the spe cirs. Lut the obrions conclusion, firm the fuet that ciflerent subtypes of one species exist in diflerent Zoologial provinees assuciated severally with distinct species of other genera, is lohlly athmed ; viz. plumality of origin, with the same original difterences which now exist. Fullowing so emincnt an authority and safe a guide, we need no longer hesitate to state the hypulle-is, which wes prepared with the remaks above referred to, on the 'sinuata' group of Helices.

The diemibuinu of the ferretrial Mollues in .Jamaica, (ant prohally of all Molluses in all parts of the worde, is most eatily accounted

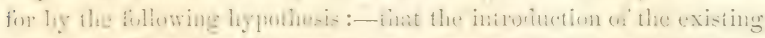

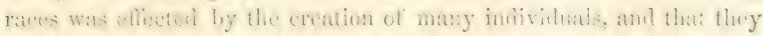
were modeled after certain types, which were mostly local, and be-

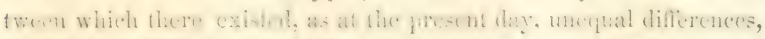

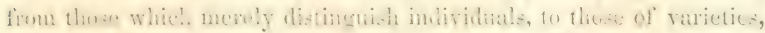
of species, of groups of species, of genera, \&c. Of course we do not mean to assert that these differenees proceed, from the less to the greater, in a regular arithmetical progression. On the contrary, it is

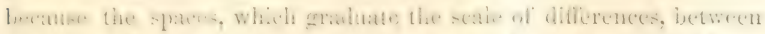

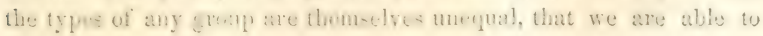

a Christian Examiner. March. 1850. Boston. 
find the limits of specics and ernera, de., in the witer spares, and of

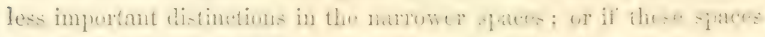

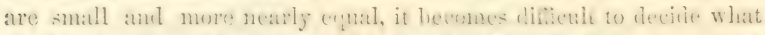

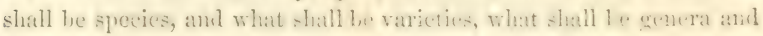
what shall bo only sections of genera. Now it is well known that

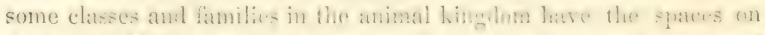
this seale of diffirenees more tine gual than others hase, so that now of

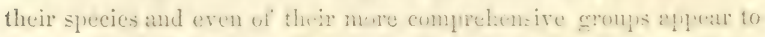

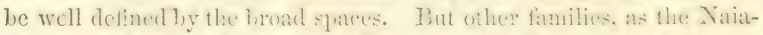

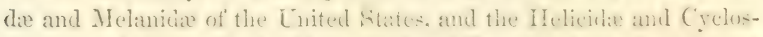
tomilie and especially the (ieomelanise of Jamaical have these spaters small and nearly equal. In such fanilies there is therefore an intrinsic difliculty in the way of deseriling good species. The preconceived notions that many persons entertain, and with which probably most of our working naturalists lecan the study of nature, leat them to expect in all cases very distinct matural limits of species. Ifence they are liable to ascribe a want of discrimination to the naturalist, who shall have undertaken to describe such groups.

The progress of iliscurery tends, more or less rapidly in tifferent classes, to fill up the wider spaces existing between known types.

The laws of hybrility do not conflict with thesc views of the nature of species. Ifitherto observations relating to them lase been chiefly directed to species which are clearly separated from their congeners. So fir as observations extend, the fucility of hybridity appears to be inversely as the space between tlie types. If this conld be proved to be a strict law, ohvionsly hybritity wouhl firnish a measure of these intersaces, or conversty might lie predicted from them.

If these views are correct, we cannot retain the prevalent theory, that species are natumal grouls, hat that genema and oblier groujs are artincial. Ail grengs are natumber far at the are fom led an actual types. Any groups are artificial, or to speak more correctly and in-

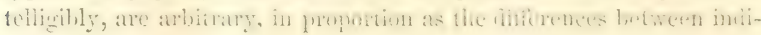
viduals, rarieties, species, and the sucessively more comprehensive groups, present a series of an indefinite number of nearly equal degrees. In proportion to the equality of the degrees, are the points, at which we mark off species and genera \&.e., arbitrary.

It must be acknowledged that these riews are not essentially different from the theory of spontancous generation, when that theory is dis-

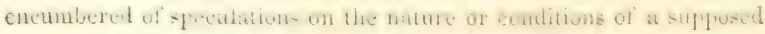


process by which animsts are protueed. The idua of the introduction of many imlivieluat of a species without parentage is common to both theories. Of the name of the proess, or even of the existence of any process more than the volition of the Divine Mind, we have

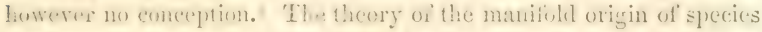
apmoximate more mesly to that of spmentameous remeration, if we

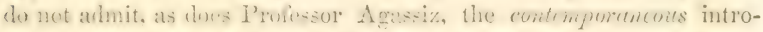

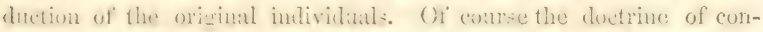

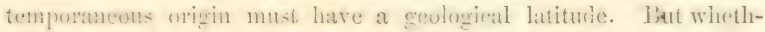

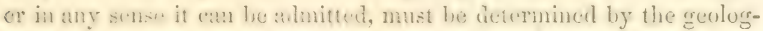
ieal history of sperius. If the subtypes of those species, whose lon-

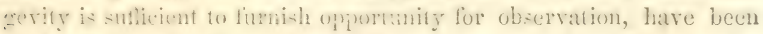

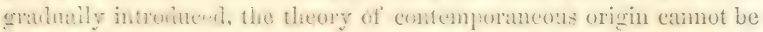

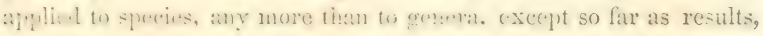
with a mathematical mesity, from the circumatiuce that they are less comprehensive groups.

It is olviuus that an illustration of this suljeet may be found in the different species and varieties of mankind.* *

Di:crijtion of a now renus of IInLerinde, from Jamaira. By C. B. Adams. March. 1550.

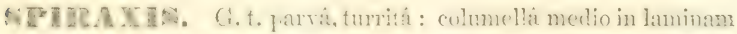
spiratun probluta: apresuaci ovali, melio lartim divisit: ]aloro simplice.

Shell statl and thin, much chnment: with the columella protuc-

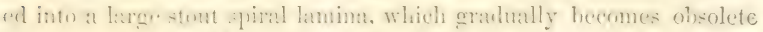

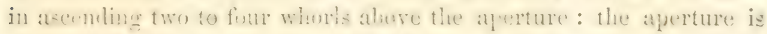
wat, hut by the contraction ef the lathun and the intrusion of the

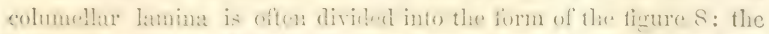
babrum is simple and imbented $1, y$ a stricture on the milille of the

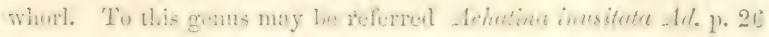

* In this case all the arguments, which some philologists urge ngainst the theory of the plural origin of the nations which speak atliliated languages, are based on the assumption that original individuals could not have had the same nor erens similar languages. Why it should be assumed that unity of Zoological origin is a necessary inferenee from philogical affiliation or unity, we are unable to conceive. It seems to us a perfect exanple of a non-sequitur. 
(of this work), which will therefore take the name of Syrictris imesitulu Ad.; and the two followidg frecies. Like many other of the species of small land slells of Jamaica, the individuals are extremely rare.

Sirmaxis aberraxs. Sin ll elongate, nearly eylindrical in the lower

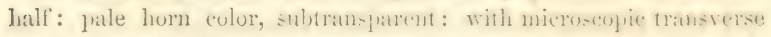

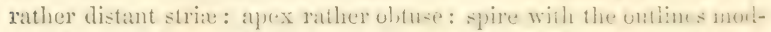
erately curved: whorls a little more than six, slifhly comrex, with a

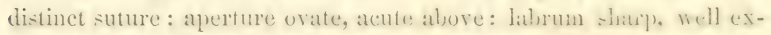
eurred, projecting a litte in the upper halt: columella with a moberately developed spiral lamella. This is probably ielentical with Achatina aberrans Pfr.

Mean divergence ahout $1 ; 3^{\circ}$; length of spire .21 inch; total length .28 inch; breadth .065 inch.

Srraxis costerosi. Shell elongate-conie: whitish or horn colored: with thinty-five to forty ohuse aylundinate transrerse ribs: apex obtuse: spire with the outlines alinost rectilinear execpt near the apex: whorls seven and onc-halt, very convex, with a deep suture; last two or three whorls whit a siral con-trietion on the midrlle, which gradually increases to the labrum, which is much intlented hy it : columellar lamina large.

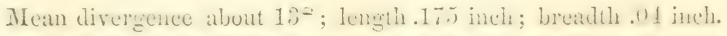

Deseription of Jurarcis, a new sulgenus of Cyclostuma. Ty C. B. Adams. MIarch. 1850.

Cyelostoma t. Cinanopomiformi, aperturi orliculari, margine simplici: operetulo extus spiraliter lamellituro, et maxime convexo, intus laevi et maximè concavo.

The shell resembles the more typical species of Choanopoma, hut has the peritreme simple, with the colge net mulh sharpened. The operenlum is extremely convex extemally and comeave within : it has a spiral lamella, and its strie of growal are lanellitirous. The only speceies known to us is deseribed leelow, meler the nane of Cyclostoma anomalum.

Notes on certain species of the land shells of Jamaica. 13y C. I3. Adams. March. 1850.

Some varieties of Ildicine Ifollanïi vecur, in which the shell is 


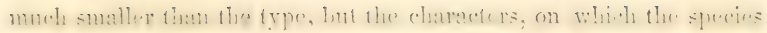
was proposed, applat to be constant.

A variety of Lucidellu aureola is so strongly sculptured with gran-

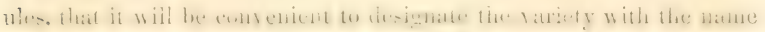
of granulosa.

A large and rery dark colored rariety of Cyclostoma Juyanum lias the outer peritreme black, and may be designated by the name of migrilabre.

Haring received fresh specimens, with their opercula, of Cyclostoma Chitlyi, I an able to confirm the validity of the species, which was proposed with some hesitation on p. 1. of this work. The whorls of these shells have a little more dianeter than those of the original specimen, being about equal to those of $C$. fimbriatulum

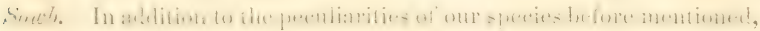
we find those of the opereulum especially worthy of notice. In C. fimbriatulum, the spiral lamella is inclined almost to a horizontal position, with a breadth equal to one-fourth the diameter of the opeculum. In the operculum of C. Chittyi, the spiral lamella, in its last

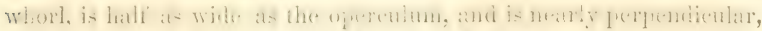

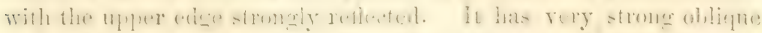

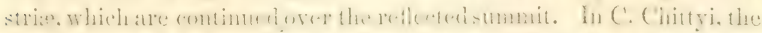

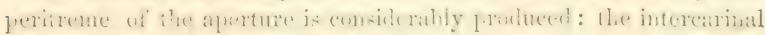

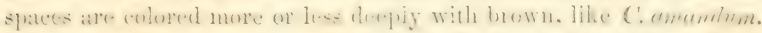

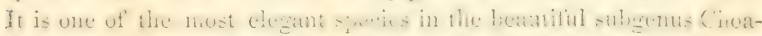
nopoma.

The two species, which were referred to Cylindrella, as a Genme-

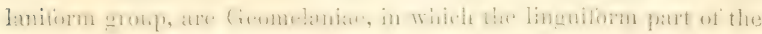
labrum is obtuse and moderately produced. Tre may now reckon 19 species of this interesting genus. In Geomelanid Brardsceara Mr Chitty has observed an operculum. The other species referred to will take the name of GEOMELANia PYGarAfa.

In the description of Geomelaniae on p. 18, the mean divergenee

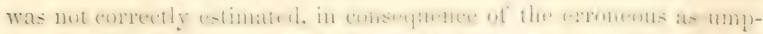

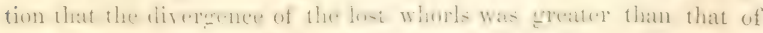

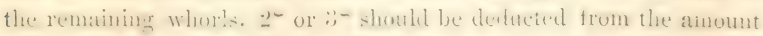
assigned to each species.

Erata. In printing the description of $G$. elegans, the word 'except' was omitted from the last sentence, which should be read precisely as in the deseription of $G$. striosa on a subsegent page.

On p. 47, line 17 from the botlom, erase 'I. hacmastoma Moric,' and three lines below for 'two' read one, and for ' third' read 'second. Gray.'

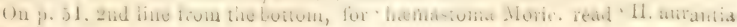


In $C$. efreme the spiral strie ascent the sildes of their ribs, but do not impress their edges.

In Geomelania the nucleus generally consists of two whorls, of which the second is larger than the following whorl.

At 'the Falls' in the eastern part of Jamaica, Mr. Chitty has fonnd

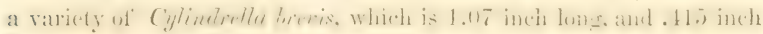
in diameter! The lip is rather more expanded than is common in C. brevis, but I am unable to detect any other peculiarity. Some of the specimens from the same locality are of much less size.

A variety of Achatina pellucens has a few transwerse brown stripes.

Description of supposed new species of land shells which inhabit Jamaica; continted from p. 84. By C. B. Adams. March. 1850.

Cyclostoma virgineum. Shell short, globose-conic: dingy white, with transverse brown lines, most of which are on the last whorl; with the peritreme deep red : with crowded transwerse rather strong perpendicular lamellae, which are decusated by the slemter spiral ridges, that begin to appear on the prentit whorl and are well developed on the last where, the interecetions l, eing mether mouluhus nor spinous: spire with very convex outlines: apex truncate with the loss of — whorls: whorls remaining three, rery convex, with a very decp suture; last whorl not detached in any part from the penult whorl : aperture exactly circular: inner peritreme moderately produeed and a little reflected : outer peritreme well expandent thronghont in the plane of the aperture, suhauriculate abose, finely striated concentrically, rather concave; umbilicus not very wibe, but of nearly equal diameter through the truncated summit.

Mean divergence about bir-; length .8.5 inch; greatest hreath .39 inch; least breadth .28 inch.

Crclostona anomalom. Shell short, globose-conic: on the upper whorls very pale brown; on the last two whorls with numerous fine spiral lines of very pale brown on the rideres and of dark lomwn in the interspates: with very mumerons suimal rideres, of which a tew

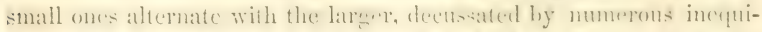
distant transerse perpendicular lamella, which are developerl, at the 
inleracetions, into triangular points thickened at their hases : spire short, with the outlines curvilinear: apex usually truncate, with the loss of one and one half or two whorls: whorls remaining about three and one-half, very convex, with a very deep suture; last whorl momeratedy detarled from the penult whor near the aperture: aperture orbicular: contrated slighly at the matring which is neither

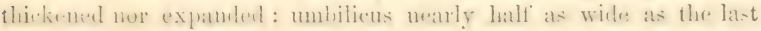

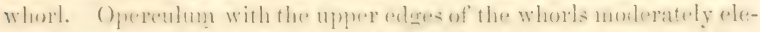

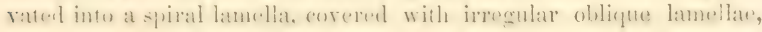
extremely comsex extermally and comeave internally: the dianeter of

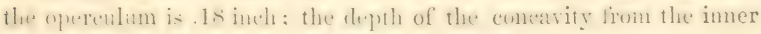
side is .07 inch!

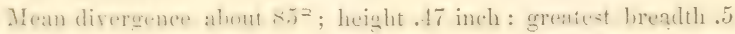
inch; least breadth .385 inch.

Cxclostoma xodulosum. Shell elongate, orate-conic: purple

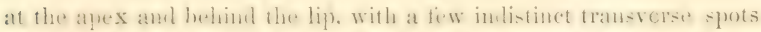
of jurpli-h lowwn and an anterior spiral band of the same; with the

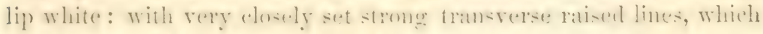

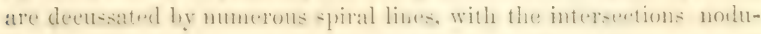
lous: spire rather long, with the outlines scarcely curvilinear: apex truncate, with the loss of — whorls : four whorls remaining, with a deep suture; last whorl not detached from the penult whor': aper-

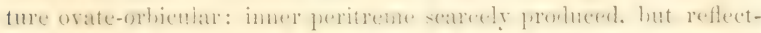

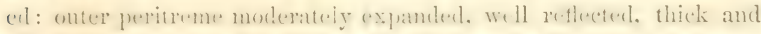
strong : mbilicus rery namow, lont extemling through the truncate aliex.

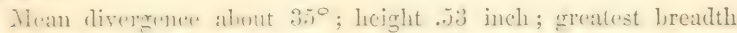
.34 inch; least breadth .25 inch.

Crclostona Retrorsur. Shell subovate: horn color, with small irregular flames of brown, and a few small dots of the same, which are inequiclistant in spiral series: with numerous fine spiral ridges, (of which one or two next the suture are larger), which are

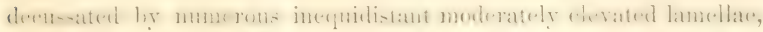

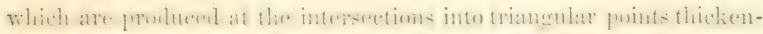

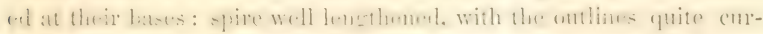
vilinear: apex truncate, with the loss of - whorls: remaining whorls nearly four, very convex, with a deep suture; last whorl not

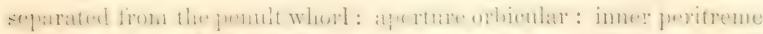

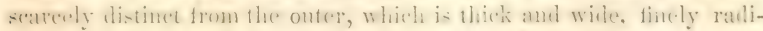
ated with impresesed lines, and retiected rory far belind the plane of 
the aperture, so at to form a canal behind it: umbilicus rery small, but extending through the truncate apex.

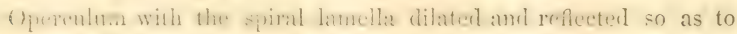
leave only a very narrow channel between its whorls.

A line pretinet specimen, lonach to me by Mr. Comning, hats enabled me to describe the operculum and the color of the shell.

Mean divergence about $50^{\circ}$; length .615 inch; greatest breadth .5 inch; least brealth . 33 inch.

Cyclostoma Shepardiaxum. Shell long orate-conic: color very various, from horn color to reddish brown or slate color, with

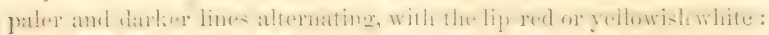

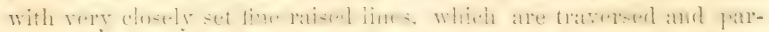
tially interrupted by numerous finely wared or zigzag spiral strix; with the upper ends of the transverse lines somewhat fascicled: spire long, with the outlines a little curvilinear: apex truneate, with the loss of — whorls : remaining whorls five to five and one-half, very convex, with a deep suture; the last whorl detached at its extremity from the penult whorl: aperture ovate-orbicular: inner peritreme

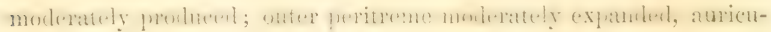
Jate above, almost wanting on the left side: umbilicus very narrow, extending through the truncate apex.

Mean divergence. Length. Greatest breadth. Least breadth.

\begin{tabular}{|c|c|c|c|c|}
\hline No. & 1. $35^{\circ}$ & .35 inch. & .25 inch. & .2 inch. \\
\hline 66 & 2. $33^{\circ}$ & .57 & .31 & .225 \\
\hline " & 3. $33^{\circ}$ & .48 & .31 & .26 \\
\hline " & 4. $30^{\circ}$ & .46 & .26 & $.225 *$ \\
\hline “" & 5. $29^{\circ}$ & .32 & .18 & .13 \\
\hline "6 & $25^{\circ}$ & $.4 \check{5}$ & .22 & .17 \\
\hline
\end{tabular}

The variations in color, in sculpture, in the degree of detachment of the last whorl, in form and in size, are remarkable. The varieties of coloring are sufficiently described abore: those of sculpture depend on the oceasional presence of delieate varices and the development of the spiral strix, which are coarse or fine or scarcely perceptible: the distance of the aperture from the penult whorl varies from one-fifth to one-half of the diameter of the aperture.

Cxclostoma paprraclem. Shell much elongated, ovate-conic: with dark brown irregular transverse bands, which are deeply and

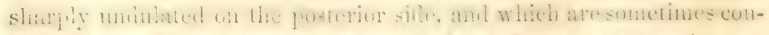
tracteri into waring lines, an a glound of pale brown: thin; elegatot-

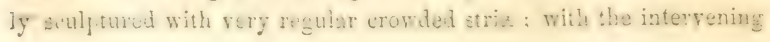


ridtons crossed by many mieroscopic spiral jmpressed lines; with a croweled sutural series of sharp crenulations: spire long. with the outlines moderately curvilinear: apex truncate with the loss of whorls: a little more than five whorls remaining, with a moderately impresed suture : aperture ovate, rather large and spreading, a little molified by the penult whorl: peritreme single, scarcely reflected to the plane of the aperture, on the left side appressed to the penult wholl: umhilicus small, with strous spiral stria. This beatiful species receires the appropriate name sugrgested by Mr. Chitty.

Mran divergence :320 ; length .\$2 iach ; greatest breatth .45 inch; least breadth .33 inch.

Cremosoma Cinmoturaxir. Shell orate-conie, much elongated: with four to six spiral frequently interrupted lines of dark brown, on a wrouml of very pale redelish hrown between,- -and whitish on the summits of - the transverse ridges: with crowded fine

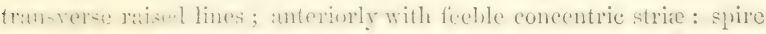

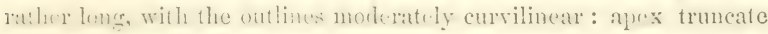
with the loss of — whorls: whorls remaining five, convex, with a well impressed suture: aperture ovate, rather acute above: peritreme simple, molerately expunded and reflected, minutely auriculate above: umbilicus small.

Yoan diverenee aheut 810 ; length .5.) inch; greatest breadh 28 inch; least breadth .25 inch.

Crclostoma gravosum. Shell long orate-conic: dingy white, with some iregular hown spots next below the suture, with a faint spinal mint of the same anteriorly, rechli-h brown near the end of the last whorl: surface gramosely decussated by numerous small transrerse and spiral ridges, of which the latter commenee on the second

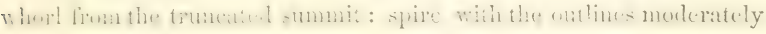
convex: whorls remaining after truncation four and onc-lialf, quite convex, with a rather deep suture : aperture nearly circular, with the

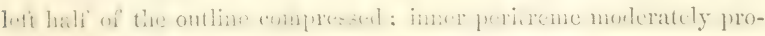
duced: outer peritreme thick, narrow, with the margin reflected be-

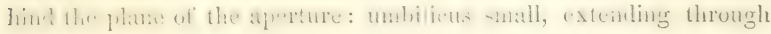
the truncated summit.

Mean divergence alhout $33^{\circ}$; length .6 inch; greatest breadth .37 inch; least breadth. 3 inch.

Helicina dubiosa. Shell globose-conic: shining, reddish brown, with the lip and callus yellowish white: with excessively fine strie of growth, and very lightly impressed microscopic spiral stria: apex 
siluacute: spire well elevater, with the outlines rather conrex: whorls four and one-half, rather convex, with a well impressed suture: aperture rather large, semicircular, with the noteh at the base

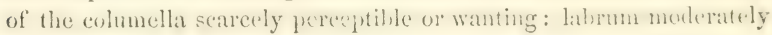
reflected and thickened.

Mean divergence about $120^{\circ}$; height .2 inch; greatest breadth $.2 S 5$ inch; least breadth .24 inch.

Var. intermedia; with a very small but distinct obtuse notch; the spire is less clevaterl, and the shell is larger amel thimer. The thould! have considered this a distinct specese, hut are unale to fim it-limits in a series of specimens. It is intermediate between the type of the spccies and $H$. solitaria, the latter having an acute-angled notcly. Height .24 inch; greatest breadth .24 inch; least breadth .29 inch.

I am indebted to the Hon. Edward Chitty for the opportunity of examining all the Geomelaniae, which he has collecterl. The different types graduate into each other, so as to remler the establishment of species extremely difficult. The value of the dithereices appears to be in the following oreler; 1 , of the linguiform part * of the lathtum; 2 , of sculpture; 3 , of form; 4 , of size. The color is absolutely the same in all the species which I have seen. There are four distinct

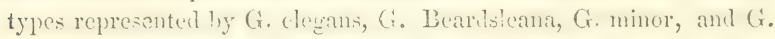
typica or G. fortis.

Geomelnard Fortis.- Shell clongate conic: whitish: with, on each whorl, about thirty-six rather slender transverse areuated ribs: spire with rectilinear outlines: apex truncate with the loss of about eight whorls: whorls remaining seven, moderately convex, with a mell impressed suture: aperture ovate, widely and deeply efluse: labrum well expanded and reflected; with the linguiform part at the anterior extremity, excessively produced obliquely and downwards, rather narrow, acute: labium well thickened, slightly separated from the penult whorl.

Mean divergence about $12^{\circ}$; length .6 inch ; greatest breadih .18 inch; least breadth .15 inch.

GEOMELANIA HAGNA. Shell clongate conic: whitish: with, on each whorl, about thirty-cight rather slender transverse much areuated ribs: spire with rectilinear outlines: apex truncate with the loss of eight whorls: whorls remaining six and one half, moderately convex, with a well impressed suture : apcrture ovate, widely and decply eíluse: labrum well expanded and reflected; with the linguiform

* This is more corretly denomiuatcd a part of than an appandage to the labrum. 


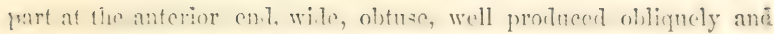

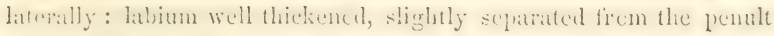
wirorl.

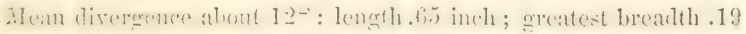
inch; least breadth .15 inch: length of the part lost by truncation .22 inch.

Geometania procera. Shell slender, conic-cylindrical: whitish : with, on each whorl, about thirty stout prominent, acute-edged transverse ribs, which are continued nearly to the anterior margin of the apreture; with rely numerots mirezopic lightly impresect spiral strix in the intercostal spaces: spire with rectilinear outlines: apex truncate with the loss of seven or eight whorls; whorls remaining seven to seren and one-half, moderately convex, with a well impressed suture: aperture ovate, widely and deeply effuse: labrum well expanded, reflected, and thickened; with the linguiform part at the anterior extremity well produced obliquely and downwards, rather narrow, but not acute: labium well thickened, separated slightly fiom the penult whorl.

Mean divergenec about $10^{\circ}$; length .63 inch; greatest breadth 15 inch; least breadth .13 inch.

Geomelayia gracilis. Shell similar to that of G.procera; but the ribs are much more slender and numerous (about forty on each whorl), and are more or less inequidistant; only very slight traces of spiral strix can be detected under a magnifier : the apex is truncate with the loss of eight whorls: the linguiform part of the lip is subacute, and is much produced obliquely and laterally at the lower extremity of the right side: the labium is as thick as the labrum.

Mean divergence about $10^{\circ}$; length 55 inch; greatest breadth .13 inch; least breatth 11 inch.

Var. parea is but .35 inch long, and has about thirty-six ribs.

Geonecaxid txplc1. Shell slender, conic: whitish: with, on each whorl, about twenty-six to thirty prominent acute-edged transverse ribs, which become obsolete only near the anterior extremity;

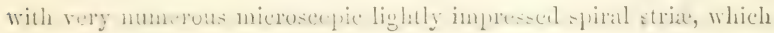
do not traverse the summits of the ribs: spire with rectilinen outlines:-apex truncate with the loss of seven or eight whorls: whorls

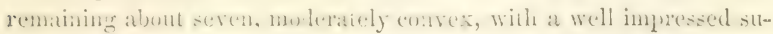

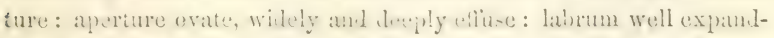
ed, notheratcly thiclanent; with the linguiform part at the anterion

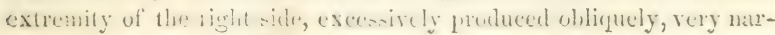


now and sulacute: labium well thickencel, a little reflectrd and separated from the penult whorl except at the upper extremity.

Mean divergence about $10^{\circ}$; length .47 inch; greatest breadth .125 inch; least breadth .11 inch.

Var. pygmaea is but .3 inch long.

Geomelania affinis. Shell similar to that of G. expansa, but the aperture is very deeply effuse anteriorly, and the linguicion part of the lip is excessirely produced oblipuety, and is namen : the apex is trmeate with the loss of alhout seren whorls. Dinnenions nearly as in $\mathrm{G}$. expansa.

Geomelania media. Shell nearly cylindrical: whitish: with, on each whorl, about thirty-five much arcuated fumbent areute-erleged rather slender transverse ribs: spire with rectilinear outlines: apex truncate with the loss of — whorls: whorls remaining six, moderately convex, with a well impressed suture : aperture ovate, wide-

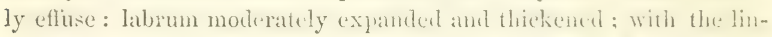
guitorm part at the anterion extremity of the right sile, well poluced obliquely, not very narrow, subacute: labium well thickened, separated slightly from the penult whorl exeept at the upper extremity.

Mean divergence about $11^{\circ}$; length .4 inch; greatest breadth .107 inch; least breadth .1 inch.

Geomelanid ricina. Shell similar to that of $G$. minor, with a greater divergence: it is usually thinner: the linguiform part of the lip is excessively produced laterally, and is very wide: the periphery of the last whorl is more angular than in G. minor.

Geomedanta striosa. Shell conic-cylindrical: whitish: with, on each whorl, about sixteen very slender somewhat areuate ribs, and twenty-five to thirty fine spiral strie, which traverse the ribs, but are sometimes obsolete on their summits; spire with rectilinear outlines: apex truncate with the loss of —— whorls: whorls remaining about seven, moderately convex, with a deep suture: aperture ovate, widely and deeply effuse: labrum well expanded, reflected, and thickened; with the linguiform part moderately produced obtusely and obliquely at the lower part of the right side: labium well thickened, slightly separated from the ponult whorl exept at the uper extremity.

Mean divergence about $10^{\circ}$; length .38 inch; greatest breadth .085 inch : least breadth .08 inch.

Geomerania costulosa. Shell conic-cylindrical : whitish : with, on each whorl, about forty rery slender somemlat areuatcel trans 
verse ribs, which are continued to the margin of the aperture, and which are much widened at their bases; with a few inequidistant

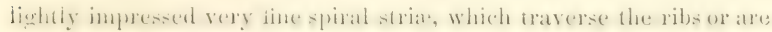

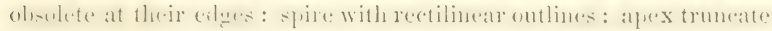
with the loss of — whorls: whorls remaining about six and onelaalf, quite convex, with a deep suture: aperture orate, widely effuse: labrim moderateiy reflected and thickened; with the linguiform part very obtuse and produced laterally in the lower half' of the right side: labium well thickened, very widely detached from the penult whorl, and united to the labrum above at some distance from the extremity of the latter.

Mean divergence about $13^{\circ}$; length .37 inch; greatest breadth .115 inch; least breadth .1 inch.

Geomelania coxica. Shell elongate conic; whitish: with, on each whorl, thirty to thirty-five transwerse slender moderately arcuated ribs: spire with rectilinear outlines: apex truncate with the loss of five whorls: whorls remaining seven, moderately convex, with a well impressed suture : aperture ovate, rather widely effuse : labrum a little expanted and ietlected, with the linguitom pant exce-sively produced obliquely, and acute, at the lower part of the right side.

Niean divergence about $13^{\circ}$; entire length .39 inch; greatest breadth .09 inch; least breadth .08 inch.

Geomelania pauperata. Shell elongate conic: whitish: with, on each whorl, about twenty-five rather wide obtuse transverse ribs: spire with rectilinear outlines: apex truncate with loss of whorls: whorls remaining seren to eight, quite convex, with a well impressed suture: aperture ovate, slightly efluse: linguiform part of the labrum but slightly produced. This speeies resembles G. pyormaea and $\mathrm{G}$. Beardsleana.

Mean divergence about $11^{\circ}$; length .21 inch; breadth .05 inch.

Geomelania exilis. Shell much elongated, conic-cylindrical: whitish : with, on each whorl, about thirty-five transverse, very slender, straight ribs, and numerous fine spiral stria which do not imfress the summits of the rihs: spire with metilimententines: apex truncate with the loss of — whorls: whorls remaining seven, quite convex, with a deep suture: aperture broadly ovate, widely and

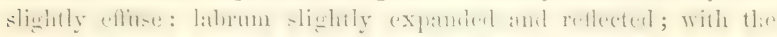

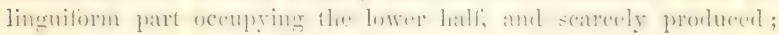
labium ar much thickented and reflected ats the lathum, rather widely separated throughout from the penult whorl. 
Nean divergence about $10^{\circ}$; length .27 inch; greatest breadth .061 inch; least breadth .056 inch.

Cylixirelat costulosa. Shell fusiform, well elongated: whitish: with prominent somewhat oblique ribs, of which there are about fourteen or fifteen on each whorl, and which are more crowded and less prominent on the last whorl; with distinct crowded stria parallel with the ribs: spire truncate with the loss of — whorls; whorls remaining seren or eight, flattened, with a deep suture: last whorl much detached and produced, obtusely angulated on the right and anterior sides; aperture dilated, angulated anteriorly and on the right; lip well expanded, moderately reflecterl, sharp. For the loan of this species $I$ an indebted to Mir. Cuming.

Length .34 inch; breatth .09 inch.

[TO BE CONTINLID]

On page 33 we described Lelix sutphurea as 'perhaps a young shell.' This opinion was founted on its papyraceous appearme. Mr. Chitty, from whom the original specimens were received, has recently furmished a series, which shews that this shell, with all the generic eharacters of Helix, is the last embryonic stage of the West Indian variety of Dolium perdix! In a mature D. perdix, this nueleus may be distinguished. In a young shell, near the apex, may be very easily seen a clearly defined margin of the nucleus, at which margin the smooth and polished nuclear surfice is abruptly sueceded by the close spiral stria which characterise the West Indian D. perdix. In the change from a continuous to a notehed aperture, the anterior extremity becomes first angular, and before the next whorl is completed, the noteht is perfect.

This example is instructive, not only as illustrating our depenclence for true generic types on the soft parts, but also as indicating the inferior rank of the Ilelicidae as compared with the Purptiridae. A

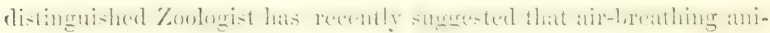
mals are of higher rank than aquatic fumilies of the same class. But so far as may be inferred firom the embryonic history of the shells, the Lamarekian system is sustained in its general outlines.

The synomymy of Helix picturata (v. p. 30) needs some elucidation, and we ofter the following remarks in the hope of contributing to this object. By some authors this shell has been mistaken for $H$.

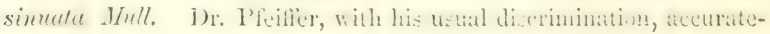


ly distingnisles it, hut assigns to it the rank only of a rariety of that species, with the following characters:

6.3. Depressior, maculis fulguratis einereis ornata, perist. magis incrassato: diam. maj. 26, min. 23, alt. 13 mill."

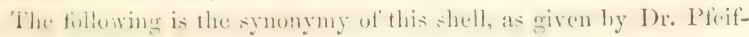
fer :

"Ilelix simuata Born Mus. p. 370 . t. 14 f. 13. 14.

— - Deless. recueil t. 26, f. 10.

- sinuosa Gmel. p. 3622. N. 163.

— - Fer. pr. 117. Hist. t. 54. 3."

The figures of Isorn appear to have been made from one of the rather more globular forms of this group of Helices; possibly from that which we have called $H$. valida (p. 77), or more probably from some rariety of $I I$. sintanta as we would restrict this species. The form is plainly much less compressed than that of $\mathrm{H}$ picturata. The f'gure of Ferussac seems to represent the same rariety.

In the text, Born expressly says of his shell, "color fuscus, fascia media cujusvis anfractus transversa alba." This is evidently au accurate description of the color of the typical II. sinuata, but not of the color of H. picturata.

Gimelin, in the thirteenth edition of the Systema Naturac, refers to the above quoted figures of Born in the description of $H$. sinuosa. If Born's fignres represent Gmelin's shell, then, for the reasons above given, H. sinuosa is not H. picturata. Gmelin's description is equally applicable to sereral species of this group, and even of other groups of Ilelices, except in respect of one phrase, "apertura transversa septery.dentata," which is not true of any in the group. If there be no error in his text, it would seem impossible to refer any of these sliells to II. sinnosa, for the number of teeth in them is absolutely constant. In no case therefore can the name of II. sinuosa be used for H. picturata.

Of the two remaining references, in the synonymy of Dr. Pfeiffer, both Delessert and Kuster (the latter in Chem. Eil. 2da.), unques-

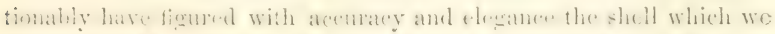
hase called li. picturatal, but they hase: contometed it with II. sintrata.

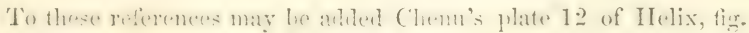

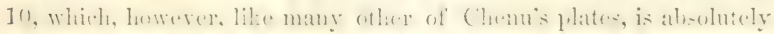

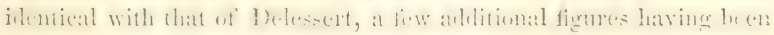
engraved in the spaces between the figures of the latter author. 
It remains to impuire which of the two sleclls was originally des-

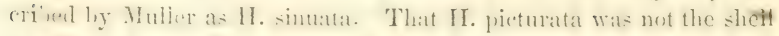

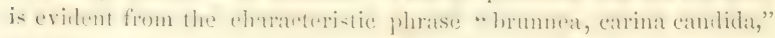
and from the words below "carina in medio candidissima."

Muller, referring to Lister t. 98. f. 99, evidently comprehended within the H. sinuata one of those forms in which the two outer teeth are foined at bas:, with a single exterior pit for both, a $=$ in II. valida and $\mathrm{H}$. Bromnii. Consequently not in this reference, any more than

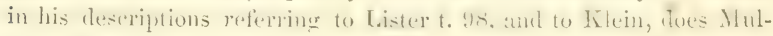
ler appear to have distinguisned $\mathrm{H}$. picturata.

It remains only to consider the value of the characters, which separate II. picturata from II. -inuata. To the charateristics mentioned on p. 30, should be alded that the carina is never white as in $\mathrm{H}$. simuata. Although this group of shells is rery perplexing on aceount of the want of constant chatucters, the perculiarities of II. picturata are remarkably constant. In a multitude of $\mathrm{H}$. sinuata and many of H. picturata we have never found a passage from the one to the other. The only and a distant approximation to a convecting link is in H. propenuda (p. 79).

The II. picturata without umbilicus, which was dwecribed (p. 80) as variety $a$, proves to be the most common form. The beautiful $H$. formosa Fer. is a kindred but distinct species. We offer the following as the synonymy of our shell.

\section{HeLix Picturata.}

— sinuata Deless. Recueil. pl. 26. f. 10.

\begin{tabular}{l}
$-\quad-\quad$ var. Kust. in Chem. Ed. II. Helix pl. 15. f. 56. \\
Chenu. Helix pl. 12. f. 10a, 10b, 10e. (exclus. 1847. \\
$-\quad$ var. \& Pfr. Mon. Hel. vir. I. p. 305. No. 796. Syn. \\
\hline picturata Ad. Cont. Conch. p. 30, 40. Oct. 1849.
\end{tabular}

It afforls me muh pleasure to acknowledere my indelitedness to my friend Dr. J. C. Jay, for his aid in examining the synonymy of this and other species, and for the use of his very ample library of Conchology, which, with his extually rich am ample collection of shells, constitute a Conchological pamali-. une unalled in this country. 


\section{CONTRIBUTIONS TO CONCHOLOGY.}

No. 7.

Descriptions of supposed new spectes of Land Suells, wilci inhamit Janaica-continued from page 98 . By C. B. Adams. April, 1850.

Helicina ampliata. Shell conic: whitish (?) : with a few excessively fine strix of growth; otherwise smooth and shining: apex subacute: spire much elevated, with the outlines moderately curvilinear: whorls five and one half, a little convex, with a distinct suture; last whorl subangular, anteriorly subplanulate: aperture transversely much dilated, depressed in the upper part of the right side: labium with a large thick deposit. This shell resembles II. Jamaiconsis Sowb., but is much larger, much less globose, and more conic.

Nean divergence about $90^{\circ}$; height .6 inch; greatest breadth .67 inch; least breadth .57 inch.

Helicina pusilita. Shell depressed globular: horn color for brownish (?) : with excessively fine stria of growth: apex subacute: spire moderately elevated, with the outlines curvilinear: whorls more than four, a little convex, with a distinct suture: aperture rather large, well rounded in the right side, somewhat sinuate in the left side; labrum thin, moderately dilated, well reflected, with a deep curved incision, similar to that of $I I$. palliata, and next below the columella, the end of which is sickle-shaped. This species is much less discoidal than $\boldsymbol{H}$. macilenta.

Mean divergence about 120 ; height 16 inch; greatest breadth .25 inch; least breadth .2 inch.

Crumorema numbs. Shell cylindrical in the lower two-fifths, tapering above: pale horn color; with rather numerous oblique, nearly straiglit equidistant fine elevated transverse lines: spire truncate, with the loss of — whorls: whorls remaining eight to eight and one-half, very convex, with a well impressed suture; last whorl stibangular anteriorly, scarcely produced from the penult whorl; 
aperture orbicular, moderately large: labrum moderately reflected and dilated, very thin.

Length .2 inch; breadth .05 inch.

Cylindrella pusilla. Shell fusiform-cylindric : pale horn color, subtranslucent: with oblique sinuous, rather inequidistant fine elevated transverse lines: spire truncate, with the loss of - whorls: whorls remaining about seven, noderately convex, with a well impressed suture; last whorl smaller than the penult whorl, from which it is not produced, with a sharp spiral keel very near the left side of the aperture: aperture very large, very oblique : lip extremely narrow, slightly thickened, well reflected. This species belong to the group, of which C. Dunkeri is a type.

Length .23 inch; breadth .06 inch.

Cylindrella pupaeformis. Shell subcylindric: pale horn color, or whitish: with excessively fine regular quite oblique strix; spire very broadly truncate, with the loss of - whorls: whorls remaining six to six and one-half, slightly convex, with a distinct suture; last whorl moderately produced from the penult whorl, subangulated anteriorly : aperture very large, a little angulated by the angle of the last whorl, orbicular: lip narrow, moderately thickened, well reflected.

Length .46 inch; breadth .13 inch.

Cylindrella procera. Shell cylindric in the lower three-fifths, moderately tapering above : reddish or yellowish brown : with rather fine regular quite oblique stria: spire very broadly truncate, with the loss of - - whorls: whorls remaining ten to eleven, moderately convex, with a well impressed suture; last whorl moderately produced, with a very prominent spiral carina anteriorly: aperture not large, suborbicular, subrectilinear in the left and upper sides, with a slight sinus between the lower and right sides: lip well reflected, moderately thickened and expanded. This is a slender species of the group, of which $C$. cylindrus $C$ hem. is typical.

Length 1.15 inch; breadth .3 inch.

Achatina costulosa. Shell conic, turrited: translucent, very pale brownish horn color, darker at the varices: with the surface apparently striated, but having on each whorl about seventy small approximate regular transverse ribs; but the nuciear whorls are smonth; with rather indistinct varices, of which there are two or three on each whorl: apex rather obtuse; spire with the outlines 
nearly rectilinear, except near the apex: whorls nearly nine, moderately convex, with a well impressed suture: aperture broadly ovate : labrum not advanced along the middle, much reflected in the fower half: columella moderately produced, nearly straight, well tıuncated.

Mean divergence about $20^{\circ}$; length of spire .65 inch; total length .86 inch; breadth .27 inch.

Achatina nitida. Shell well elongated, ovate-fusiform: reddish brown, with very dark brown transverse stripes, about four or five on each whorl: varicose coincidently with the brown stripes, the vat rices being indicated by the thickening of the shell within, and a deeply impressed line in front of each; well polished and shining : apex subacute: spire with the outlines rectilinear, or moderately convex: whorls seren to eight, moderately convex, with a well impressed suture : aperture leng ovate, very acute above : labrum sharp, subangular at two-thirds of the distance from its upper extremity: columella much curved, broadly truncated.

Mean divergence $30^{\circ}$ to 35 ; length .96 inch; greatest bieadth .31 inch; lenst breadth .3 inch; length of aperture .44 inch.

Achatra Garana. Shell well elongated ovate-fusiform: light brownish yellow, with a series of very distant trianguiar spots of dirk brown, descending from the suture, about five or six on each whorl: varicose coincidently witl the brown spots, the varices being rather feebly indicated, as in $A$. nitida; with fine regular rather crowded transwerse strix: apex subacute: spire with the outlines a little convex: whorls seven or eight, rather convex, with a well impresed suture: aperture long orate, acute above: labrum sharp and thin : columella nearly straight, rather narrow and obliqualy truncated.

Mean divergence about $300^{\circ}$; length .76 inch; greatest breadth .27 inch; least breadih $.25 \mathrm{inch}$; length of aperture $.36 \mathrm{inch}$.

This rare and elegant species is dedicated to my assintant, Mr. A. II. Gay, in testimony of his industry and rapid acquisitions in natural history.

Achitivi smilis. Shell similar to A. nemorensis, but the outlines of the spire are nearly rectilinear, and consequently the spire is more slender; the surface is highly polished, and has but a tew excessively fine transwerse strie; the brown stripes are wider. It also 


\section{4}

resembles $A$. Phillipsii, but its spire is shorter, with a greater divergence.

Mean divergence about $22 \supset$; length of spire .45 inch; total length $.75 \mathrm{inch}$; breadth .23 inch.

Achatina tenera. Shell elongate, somewhat conic : horn color : with numerous well impressed regular transverse striæ: apex subacute : spire with the outlines a little convex: whorls seven and onehalf, scarcely convex, somewhat shouldered above, with a well impressed suture: aperture ovate, acute above: labrum thin, slightly advanced in the upper half, retreating below : columella moderately curved, distinctly truncated.

Mean divergence about $14^{\circ}$; length of spire $.2 \mathrm{~L}$ inch; total length .3 inch; breadth .075 inch.

Aciratina longispira. Shell much elongated, conoidal: pale brown : shining, with very lightly impresserl not very numerous transverse strite: apex obtuse: outlines of the spire slightly curvilincar: whorls ten, moderately convex, with a well impressed suture: aperture subrhomboidal, subacute above: labrum thin, slightly advanced in the upper half, retreating below: columella rery oblique, distinctly truncated.

Mean divergence about $12^{\circ}$; length of spire $.33 \mathrm{inch}$; total length, .45 inch; breadth .09 inch.

Achatina gracilior. Shell conoidal, but very slender: pale horn color: with about twelve transverse oblique slightly prominent lamelloid ridges, which are more distinct next below the suture : apex rather acute: spire with the outlines nearly rectilinear: whorls eleven, a little convex, with a distinct suture: aperture ovate, very acute above, retreating below on both sides, but less on the left side : labrum thin: columella moderately arcuated and truncated.

Mean divergence about $9^{\circ}$; length of spire .43 inch; total length .55 inch; breadth .09 inch.

Achatina osculans. Shell conoidal, but very slender; dull horn colur; with about fourteen transwerse oblique rather prominent lamelloid ridges, which are somewhat arcuated with the couvexity forwards: apex rather obtuse: spire with the outlines rectilinear, except near the apex: whorls nine, flattened or concave along the middle, with a well impressed suture: aperture ovate, very narrow and acute above, retreating much below on both sides: columella sub- 


\section{5}

spiral, distinctly truncated in a young shell, indistinctly so in an old one, with the edge somewhat dilated, so as to resemble a Spiraxis.

Mean divergence about $9^{\circ}$; length of spire $.28 \mathrm{inch}$; total length .35 inch ; breadth. 06 inch.

Heuix conncotens. Shell hemispherical: white, with a horn colored epidermis: with rather coarse stria of growth : apex very obtuse: spire with regular and rery convex outlines: whorls nine, very narrow, moderately convex, with a well impressed suture: last whorl slightly conrex beneath, with the umbilical region slightly concave: aperture nearly transverse, rather narrow, lunate; with a very prominent sharp stout revolving lamella far within in the lower part of the last whorl: labrum thin and sharp: labium in old shells, with a rather thick deposit: columella produced very obliquely; umbilicus wanting.

Mean divergence ahout $110^{\circ}$; heighṭt .68 inch; greatest breadth .1 inch'; least breadth .95 inch.

Iferix alligans. Shell globose conoid: white, with a yellowish brown epidermis: with regular stria of growth, which are very coarse on the spire, and fine on the last whorl: apex very obtuse: spire well elevated, with the outlines very convex above, nearly rectilinear below: whorls eight, narrow, rather convex, with a well impressed suture; last whorl scarcely convex beneath, with the umbilical region planulate: aperture oblique, rather broarl, lunate; with a very prominent sharp stout revolving lamella far within in the lower part of the last whorl: lahrum rather thin, sharp: columellit moderately dilated, and well rounded : unbilicus wanting. This species resembles $I I$. cpistylium and $I I$. epistylivides. It is most easily recognized by the plane surface of the umbilical region.

Divergence of the upper whorls about $140^{\circ}$; mean divergence about 9.50 ; height 1.05 iuch; greatest breadth 1.25 inch; least breadth 1.17 inch.

Hisix amabis.s. Shell nearly planulate above, very convex beneath, transversely suborbicular: blackish brown, paler on the apex and lip): surface shining, with very fine unequal strite of growth, and obsolete spiral strie on both sudes of the periphery: spire slightly elevated, convex: whorls four and onc-half, slightly convex in the upper part, and concare in the lower part, with a lightly impressed suture; last whorl with the periphery extremely acute: aperture in 
the form of a spherical triancle, moderately expanded, with three teeth in the lower side, of which the outer two stanr? wer one exterior pit, with a separate impression beneath each one, and the third is also over an exterior furrow: labrum well thickened, very much reflected: umbilicus rather wide, scarrely contracted except near the inex very obtusely. This rare and elegant species is allied to $\boldsymbol{H}$. cara and $\boldsymbol{H}$. Chittyana. inch.

Height .43 inch; greatest breadth 1.05 inch; least breadth .92

Hexix fuscolabris. Shell transversely ovate-orbicular, convex on both sides: deep reddish brown, paler next the labrum, and at the periphery, darker next below the periphery, often light green around the umbilical region, and behind the lower part of the labrum, clear brown at the margin of the lip, white within: finely but rather strongly granulated, except near the apex and the umbilical region: spire convex or subconoid, moderately elevated: whorls five and onehalf, slightly convex, often a little concare in the lower part, with a lightly impressed suture: last whorl with a rather asute periphery: aperture almost horizontal, sublunate, moderately dilated; with, on the lower side, two white teeth, of which the outer one is very large, and both of which are accompanied exteriorly with proportionate furrows: labrum moderately thickened and reflected, much thicker and more reflectod next the colnmella. This species is intermediate between $\boldsymbol{H}$. lucerna and $\boldsymbol{H}$. acuta.

Hcight.i2 inch; greatest breadth 1.5 inch; least breadth 1.26 inch.

Hifix nobitis. Shell transrersely ovate-orbicular, moderately and irregularly convex above, regularly and very convex beneath: above reddisin or blackish brown, with paler spaces: beneath with a broad belt of blackish brown next below the periphery, within which the shell is of a bright yellowish green; with the lip purple, irregularly spotted with white: rather feebly granulated, smonth near the apex and umbilical region, with the lower part of the whorls, for the most part, undulated by short oblique impressions: spire moderately elevated: whorls a little more than five, subplanulate, with a lightly impressed suture; last whorl with an acnte periphery, above which it is concave in its last half, and below which it is slightly concave in its first half: aperture subtringular, with the lower outline much 
curved: with one moderately devcloped tooth below near the right side: labrum well reflected, moderately thickened : umbilicus wanting. See Lister, 82, 83.

Height 1.12 inch; greatest breadth 2.42 inch; least breadth 2.07 inch.

Helix Redfieldiama. Shell transtersely ovate, quite convex on both sides: brown, or brownish black, with a paler line on the periphery, with the lip white or purple: with coarse transverse striat, which, on the upper side of the shell, are frequently interrupted so as to resemble transversely elongated granulations: apex very obtuse: spire very convex: whorls four and one-half, moderately conrex, with a distinct but moderately impressed suture: last whorl with an acute or subacute periphery: aperture transversely and somewhat obliquely semielliptical, a little modified by the penult whorl: labrum well expanded, reflected, and thickened, expanding into a broad flattened callus, where it joins the labium at the base of the columella : umbilicus wanting.

Height 1 inch; greatest breadth 1.82 inch; least breadth 1.5 inch.

Helix Blandina. Shell transversely ovate, quite convex above, moderately convex beneath: brown, paler on the upper whorls and on the lip): with rather coarse transverse stria : apex rather obtuse : spire with the outlines quite convex: whorls five, quite convex, with a well impressed suture; last whorl with the periphery scarcely subangular: aperture oblique, lunate, considerably modified by the intrusion of the penult whorl : labrum rather thin, moderately reflected: umbilical region slightly indented.

IIeight $.42 \mathrm{inch}$; greatest breadth .63 inch; least breadth .5 .5 inch.

Hewn osculans. Shell very similar to that of $\boldsymbol{H}$. arboreoides; but the whorls increase rather less rapidly, so that the outer whorl and the aperture are not so wide as in that species; the lower side of the last whorl is thicker, and within is fumished with a stot:t revolving lamella a little exterior to the middle of this side. This species connects the groups of Jamaica Ilelices, which are represented by $H$. arborcoides and $\boldsymbol{H}$. epistylium.

II eight .21 inch; greatest breadth .41 inch; lenst breadth .11 inch. 
Proscrmina pisur. Shell globular: pale yellow and whitish: smooth and shining: apex very obtuse: spire well elevated, with very convex outlines: whorls five, quite convex, with the suture not impressed : last whorl very large and high : aperture longitudinally lunate: labrum sharp, moderately thickened within, without teeth or lamellae: columella moderately produced nearly in the direction of the axis of the shell, with one sharp prominent nearly transverse plait : labium with a very prominent and sharp revolving plait near the columella.

Mean livergence about $110^{\circ}$; length of aperture .15 inch; total length .21 inch; greatest breadth .24 inch; least breadth .2 inch.

For this elegant species of Proserpina, and several of the above species, I am indebted to my friend, Rev. F. R. IIolland, who has collected them in person; and, as on previous occasions, has liberally shared with me the results of his labors.

Additional specimens of Helix ingens, from Mr. Chitty and from Miss Agnes Hines, show that the umbilicus, although so remarkable in the specimen originally described, is often wanting! A highly colored specimen sent by Miss II. is, for both size and beauty, the most superb of all the land shells of Jamaica.

By the kinduess of Mr. Bland, I am furnished with specimens of the elegant Cyclostoma Sauliae Sucb., from Worthy Park, St. John's, Jamaica. C. suturale Somb., like must of the shells, which are ascribed to Demarara on the authority of Mr. Bainbridge, belongs to Jamaica.

If In reply to an inquiry respecting the distribution of the terrestrial shells of the Philppine Islands, Mr. Cuming says, "I did not find more than ten species the same in different islands, at which I was much surprised." The general results of Mr. Cuming's researches, in relation to the distribution of the species, marine, fluriatile, and terrestrial, of the shells of these islands, would be a most interesting and valuable contribution to science. 
Descriptions of supposed new species of Manise Suclis, which inhabit Jamaica. By C. B. Adans. April, $1 \$ 50$.

Namca (?) Anoma a. Shell ovate: white, with a tinge of brown: with, on the penult whorl four, and on the last whorl eight, stunt obtuse very prominent spiral ridges, which are decussated imbricately by very prominent regular incremental laminae: apex acute: spire with the outlines rather convex: whorls four, quite convex, with a rather deep suture; last whorl large and ventricose: aperture ovate, somewhat effuse and subacute anteriorly: labrum pectinate, rather sharp, thickened within: columella with a small transserse plait opposite the umbilicus, expanded and flattened below.

Mean divergence about $69^{\circ}$; length of spire .03 inch; total length .2 inch; breadth .13 inch.

Odostoma gemulosa. Shell ovate-turrited: white: rather thick; with, on the upper whorls, three, and on the lower whorls four stout prominent obtuse spiral ridges, and on each whorl about twenty to twenty-two trinsverse ridges, which are continued over the summits of the spiral ridges with well developed nodular intersections; anteriorly with five or six similar spiral ridges issuing from the aperture, and not decussated : apex subacute: spire with the ontlines moderately convex: whorls seren and one-half, subplanulate, with a canaliculate suture: last whorl subacute anteriorly : aperture ovate, rather acute above, moderately effuse and pointed anteriorly: columellar plait more prominent than the spiral ridges on the labium above it.

Mcan divergence nearly $20^{2}$; length .155 inch; breadth .055 incl.

Onostona cavancelata. Shell conic, turrited: white : smonth: apex acute: spire with rectulinear outlines: whorls six, planulate, with the suture in a small spiral channel; last whorl stort and abruptly terminating : aperture broally ovate: columellar plait nearly transwerse.

Mean divergence about $2 ! \rho$; length .12 inch; breatth 0.45 inch.

Obostoma orctomes. Shell rather long orate: white: smooth and shining, with a scarcely impressed spiral line next below the suture: apex subacute: spire with the outlines moderatcly conrex: whorls five and one-half, slightly convex, with a lightly impressed 
suture; last whorl long and fusoid: aperture ovate, scarcely effuse anteriorly: columellar plait quite oblique.

Mean divergence about $30^{\circ}$; length .115 inch; breadth .055 inch.

Opostoma sompula. Sheil cylindrical in the lower half, conic above: dingy white: thick and smocth: apex subacute: spire with the outlines moderately curvilinear: whorls six, moderately convex, with a distinct suture; last whorl rather long: aperture ovate, a little effuse and pointed anteriorly: columellar plait stout, obtuse, quite oblique.

Nean divergence about $20^{\circ}$; length .11 inch, breadth.04 inch.

Eulma gracilis. Shell ovate-conic, turrited: white, translizcent, opaque along the suture: smooth and shining, with an impressed spiral line next below the suture: apex acute: spire with the outlines nearly rectilinear: whot Is thirteen, slightly convex, with an indistinct suture; last whorl gradually tapering anteriorly, rather short: aperture rather narrow: labrum much advanced along the middle.

Mean divergence about $20^{\circ}$; length .24 inch; breadth .06 inch.

Eulima arcuata. Shell ovate-conic, turrited: subtransparent, white: smooth and shining, with a fine impressed spiral line above the suture: apex acute: spire with the axis curved to an extraordinary degree in the upper whorls, with the outlines moderately curvilinear in the plane perpendicular to that of the curvature: whorls ten, quite convex, with a lightly impressed suture; last whorl long and fusoid: aperture rather long ovate: labium with a well defined deposit.

Hean divergence about $25^{\circ}$; length $165 \mathrm{inch}$; breadth .055 inch.

Eulina conica. Shell conic, turrited: white: smooth and shining : apex acute: spire with the axis moderately curved throughout, with the outlines rectilinear in the plane perpendicular to that of the curviture: whorls about eleven, planulate, with an indistinct suture: last whorl subangular, quite oblique anteriorly: aperture small, ovate.

Neun divergence about 220 ; length .1 inch; breadth .042 inch.

Erlima arfinis. Shell similar to that of $\mathrm{E}$. conica, but the form is more slender, the axis scarcely curved, the last whorl less oblique anteriorly, and the aperture is larger. 
Mean divergence about $19^{2}$; length .09 inch; breadth .031 inch.

Eulma (?) fulvo-cincta. Shell ovate-conic, turrited : trimslucent, white, with a spiral band of bright brown below the middle of the whorls, and another along the suture, both of which bands are much and irregularly interrupted; with a few transverse irregular stripes of the same: smooth and shining: apex rather obtuse: spire with the outlines nearly rectilinear: whorls seven, planulate, with an indistinct suture: aperture narrow : columella subtruncated.

Mean divergence about $20^{\circ}$; length .2 inch; breadth .065 inch.

Natrca proxima. Shell obliquely ellipsoidal : mostly fawn color, or livid, white anteriorly, and on the callus, with an ill defined dingy white stripe next below the suture; anteriorly with a circle of trans. verse curved brown flames; above the middle of the last whorl, with a narrow pale revolving stripe, on which are rather distinct sagrittate spots of dark brown; sometimes next below the middle is a similar but more faintly and closely spotted line: thin, smooth, and shining, with the oblique infrasutural strixe rather feeble: apex subacute: spire prominent, with the outlines moderately curvilinear: whorls five, quite convex, with a well impressed suture: aperture not very wide, ovate but compressed in the left outline: labial deposit rather thick, but subtransparent: umbilical callus about half filling the umbilicus in the lower and right side: umbilicus rather narrow, deep, partially concealed by the labial deposit.

This species resembles the young of $\boldsymbol{N}$. canrcna, but the spire is longer; the aperture is narrower, and the form consequently not ovate: the umbilical callus is rather smaller; the shell is thinuer : the plan of coloring, although similar, is constantly difterent.

Nean divergence about 1200 ; length of aperture about $.52 \mathrm{inch}$; total length .7 inch; breadth. 6 inch.

Natica Janaicensis, Stell obliquely ellipsoidal : pale brown or livid, somewhat mottled, often with three more or less distinct revolving series of transverse curved brown flames; with a white spiral infrasutural stripe; with the umbilical callus and most of the labial de. posit dark brown: with obsolete spiral strie ; with the oblique infrasutural strie quite distinct: apex acute: spire prominent, with the outlines moderately curvilinear: whorls nearly five, mather convex, with a well impressed suture: aperture not very wide, orate but 
compressed in the left outline: labial deposit rather thick; umbilical callus nearly filling the rather narrow umbilicus.

Hean divergence about 1200 ; length of aperture .42 inch; total length .53 inch; breadth .43 inch.

Variety nigrescens is more concave around the umbilicus, is rather larger and thicker, and has the callus and interior of the aperture nearly or quite black.

Neritixa orNata. Shell obliquely ellipsoidal : rather pale greenish or livid brown, ornamented with numerous rather small irregular spots of bright red : rather thick and solid, with fine unequal strie of growth, and crowded microscopic spiral lines: spire small, not very prominent: whorls more than three, with a subeanaliculate suture: labium smooth, obsoletely toothed. Operculum divided into two concave regions by an acute ridge, which is curved in the direction of growth.

Length of spire .07 inch; total length .32 inch; breadth .24 inch.

Neritina (?) pusilla. Shell transversely ovate: white, translucent : vitreous, smooth and shining : spire scarcely elerated: whorls one and one-half, with an indistinct suture; last whorl very large, concavely depressed above: aperture very large, semiorbicular: labrum rery thin: labium tumid, corered with a large tumid smonth deposit. Obriously this species can scarcely be included in Neritina. A considerable number of specimens were obtained, which scarcely differ even in size.

Height .04 inch; greatest breadth .068 inch.

Like most of the Neritinae of Jamaica, this is strictly a marine shell.

Two or three of the following species of Risson may have been described by Orbigny in the Moll. du Cuba, but not having the text we are unable positively to identify them, and therefore offer the following preliminary description of all the species from Jimaica, which were not described in the Proc. Bost. Soc. Nat. Hist., Jan., 1845.

The same remark may be true of one or two species of Chemnitzia on pp. $72-5$.

Rissoa subangulata. Shell long ovate conic: white: with, on ench whorl, eleven or twelve rather acate but stnut ribs, which spread to their bases with concave sides, and which on the last whorl are produced to the anterior extremity; sometimes with very lightiy in- 


\section{3}

pressed microscopic spiral stria: apex acute: spire with slightly convex outlines, often with a curved axis: whorls seven and onehalf, quite convex, with a well impressed suture: aperture moderately effuse and rather large: labrum well produced and excurved, rather thick. The name of this species was originally suggested by specimens, in which the axis is more than usually distorted. Since it has been used in other collections, and in my printed catalogue of North American shells, I have not deemed it expedient to substitute a more appropriate name.

Mean divergence about $35^{\circ}$; length of spire .13 inch; total length .21 inch; breadth .095 inch.

Rissoa aberrans. Shell long ovate conic: white: strongly sculptured with three or four spiral ridges, which are decussated, with nodulous intersections, by transwerse ridges, of which there are about sixteen on each whorl; anteriorly the transwerse ridges are obsolete, and three or four additional spiral ridges are nodiferous : apex acute: spire with the right side nearly rectilinear and the left quite curvilinear, the axis being curved: whorls seven, nearly planulate, with a subcanaliculate suture; last whorl rather large: aperture rather small, deeply notched anteriorly; labruın rather thick and well excurved. This species connects the genus with those Cerithia, in which the canal is reduced to a notch.

Mean divergence about $32^{\circ}$; length of spire .1 inch; total length .165 inch; breadth .08 inch.

Risosa scaliroides. Shell long ovate conic: white: with, on each whorl, sixteen or eightcen stout ribs, which are continued to the anterior extremity: apex acute: spire with the outlines moderately curvilinear; whorls seven and one-half, slightly convex, with a well impressed suture: aperture moderately effuse: labrum well advanced and excurved, rather thick.

Mean divergence about $27^{\circ}$; length of spire .13 inch; total length .2 inch; breadth .08 inch.

Variety (?) minor is but .15 inch long.

R. scularelle Ad. (Proc. Bost. Soc. Nat. IIist., Jan. 1, 1845,) closely resembles the preceding; it has on each whorl twelve to fourteen ribs, which are larger than in $R$. scalaroides, and has, in large specimens, the following dimensions :- Mean divergence about $2 t^{5}$; length of spire .1 inch ; total length . $15.5 \mathrm{inch}$; breadth .06 inch. 
In the Zeitschrift fur Malac. $\boldsymbol{R}$. scalarella is referred to the genus Rissoina, on account of the presence of a solid calcareous operculum. Some fresh specimens obtained by me near Kingston in 1844, were found to have a horny operculum.

Rissoa laevigata. Shell long ovate conic, rather slender: white, translucent: smooth: apex acute: spire with the outlines slightly convex: whorls mearly seven, scarcely convex, with a moderately impressed suture : aperture moderately effuse : labrum well advanced and excurved, rather thick.

Miean divergence about $28^{\circ}$; length of spire .08 inch ; total length .12 inch; breadth .045 inch.

Rissoa dubiosa. Shell long ovate conic: white, translucent: with, on each whorl, nimeteen or twenty obtuse ribs, which are produced on the last whorl to the anterior extremity: apex subacute : spire with the outlines moderately curvilinear: whorls seven, rather convex, with a well impressed suture: aperture moderately effuse : labrum well advanced: excurved, moderately thickened.

Mean divergence about $2 \mathbb{S}$; length of spire .115 inch; total length .185 inch; breadth .065 inch.

Rissoa pulcura. Shell subovate, turrited: white, with a pale yellowish brown spiral band on the upper part of the whorls, and a similar band anteriorly: with spiral ridges increasing from two on the upper whorls to four or five on the penult whorl, (of which the upper one is smaller,) and on the last whorl seven, which are crossed, with well developed nodulous intersections, by twenty to twenty-two small transverse ridges; anteriorly with three nodiferous approximate spiral ridges, which are separated from the other seven by a broad groove : apex acute: spire with the outlines moderately curvilinear : whorls ten, quite convex, with a well impressed suture: aperture very efiuse: labrum well advanced and excurved, very much thickened.

Nean divergence about 220 ; length of spire .155 inch; total length .225 inch; breadth .0S inch.

Rissoa nucticostata. Shell ovate conic, turrited: white: with on each whorl, about twenty-eight very regular ribs, which are produced on the last whorl to the anterior extremity, and numerous distinct spiral striae on the anterior half of the last whorl, which impress the summits of the ribs; on the rest of the shell between the ribs are 
rery faintly impressed microsenpic spiral striae: apex acute: spire with the outlines moderately curvilinear: whorls seven, quite convex, with a well impressed suture: aperture deeply effuse: librum much excurved and very thick. Conf. Rissoina elegantissima Orb. Moll. du Cuba, Tab. XII. f. 27-29.

Mean divergence about $26^{\circ}$; length of spire .12 inch ; total length .18 inch; breadth .07 inch.

Rissoa vitrea. Shell ovate conic, turrited : with a scarcely perceptible bluish tinge, opaque white at the suture and in the thickening around the aperture; in the rest transparcnt as glass, and clearly exhibiting the internal structure : highly polished, with some scarcely perceptible microscopic strixe of growth, and a fine impressed spiral line very near and next below the suture: apex very acute : spire with the outlines moderately curvilinear: whorls nearly ten, slightly convex, with a distinct but moderately impressed suture: aperture very effuse and angular anteriorly: labrum very much excurved and advanced, moderately thickened.

Mean dirergence $26^{\circ}$; length of spire .19 inch; total length .29 inch; breadth .105 inch.

Rissoa laevissima. Shell long ovate conic: dingy white, with a very pale reddish brown spiral band on the upper part of the whorls, and two others on the middle and anterior part of the last whorl; but these bands are often obsolete, and speedily disappear in wenthering: surface highly polished: apex very acute: spire with the outlines slightly curvilinear: whorls nine, slightly convex, with a moderately impressed suture : aperture rather small, very effuse: labrum well excurved and advanced, very much thickened. Conf. Risinaina Browniana Orb. Moll. du Cuba, Tab. XII. f. 33-35.

Mean divergence about $30^{\circ}$; length of spire .13 inch; total length .2 inch; breadth .09 inch.

Rissoa eubruomes. Shell elongate conic: white, translucent in a spiral line below the suture: smooth and shining, with a brond very obtuse varix on each whorl, forming a slightly oblique line with the labrum : apex rather obtuse: spire with the axis moderately curved, convex on the left and rectilinear on the right side: whorls seven or eight, scarcely convex, with a lightly impressed suture: aperture scarcely effuse: Jabrum well excurved, not advanced, moderately thickened. 
Mean divergence about $26^{\circ}$; length of spire .14 inch; total length .2 inch; breadth .09 inch.

Rissoa striusı. Shell ovate conic, somewhat turrited: dingy white or corneons : with, on each whorl, twenty-five to twenty-eight moderately developed transverse folds, which are obsolete on the lower part of the middle whorls and on most of the last whorls; with very numerous crowded deeply impressed spiral striae; with an infrasutural impressed line larger thin the striae and constricting the whorls: apex acute: spire with the outlines moderately curvilinear : whorls nine, rather convex, with a mocerately impressed suture: aperture somewhat effuse, large: labrum well advanced, much excurved, moderately thickened.

Mean divergence about $26^{\circ}$; length of spire .135 inch; total length .2 inch; breadth .08 inch.

Rissoa princeps. Slell ovite conic, turrited: white: with very numerous crowded slender ribs, which become obsolete on the last whorl, and strong crowded spiral striae, which become larger on the last whorl: apex acute: spire with rectilinear outlines: whorls ten, nearly planulate, slightly contracted next below the suture, which is moderately impressed : aperture very effuse : labrum very much advanced a little below the middle, well excurved, moderately thickened. This species resembles $R$. allida $A d$., but that shell is much smaller, and the outines of its spire are curvilinear.

Mean divergence about $30^{\circ}$; length of spire .25 inch; total length .37 inch; breadth .14 inch.

Rissoa (?) melanura. She!l conic, turrited: white, suhtransparent, with the apex black: nearly smooth, shining, with some spiral striae, which are quite distinct anteriorly and at the lower part of the whorls of the spire, and are obsolete on the upper part of the whorls: apex acute: spire with the outlines nearly rectilinear: whorls eight, quite convex, with the suture rather deep: aperture scarcely effuse: labrum thin (?), well excurved below the middle : columella straight, subtruncite. On account of the imperfect condition of the labrum in the specimens before me, it remains doubtful, whether this shell is a Rissoa; it is evidently kindred to $\boldsymbol{R}$. tervaricosa $\boldsymbol{A} d$., whose generic chnracter is also doubtful, the labrum being thickened by the last varix.

Mean divergence about $28^{\circ}$; length of spire .2I inch; total length .28 inch; breadth .11 inch. 
Cneiturum monestum. Shell conic, turrited, sinistrorsal: reddiah black, weathering to a cinereous color: with, on the upper whorl", two, and on the middle and lower whorls three spiral ridges, which are of equal size on the lower twr-thirds of the shell; and numerous transverse ridges, the intersections boing woll devel ped nodules; anteriorly with two or three additional spiral ridges, which are lesis strongly nodulous, and which are separated by a brond groove from a small ridge around the base of the canal: apex very acute: spire with the outlines quite curvilinear: whorls about fourteen, planulate. with tìe place of the suture distinguished by a somewhat larger groove; last whorl abruptly terminating : canal short, slightly turning to the right.

Nean dirergence about $23^{\circ}$; length .225 inch; breadth .07 inch.

Cerituum melanura. Shell like that of $C$. modestum, but snow white except the dark brown apex, much more slender, with the outlines less curvilinear, and the aperture smaller.

Mean divergence about $17^{\circ}$; length .2 inch; breadth .045 inch.

Cerithum decoratum. Shell conic, turrited, sinistrorsal: white, dark reddish brown anteriorly, with many large rather square irregular spots of the same: with, on the upper whorls, two, and on the middle and lower whorls, thrse nearly equal spiral ridges, which are nearly concealed by numerous large nodules, that are produced by the excessive development of the intersections of twenty-five to twentyeight sinall transverse ridges on each whorl; anteriorly with two additional smaller or less strongly nodulous spiral ridges : apex very acute: spire with the outlines nearly rectilinear: whorls sixteen, planulate, with the place of the suture distinguished by a deeper groove; last whorl terminating very abruptly, so as to be concave between the periphery and the canal: aperture ovate-orbicular, modified a little by the penult whorl: canal strongly bent to the right, closed except near the extremity. This shell resembles C. ornatum Dcsh., but that species has only ten or twelve whorls, its outlines are quite curvilinear, and the last whorl terminates less abruptly.

Mean divergence about $20^{\circ}$; Iength .29 inch; breadth .085 inch.

Cenitmum deanisum. Shell Iike that of $C$. decoratum, but snow white; the outlines of the spire are exactly rectilinear; the granules are less developed; and the canal is nearly straight.

Cenituium nanum. Shell conic, turrited, sinistrorsal: wax brown, 


\section{8}

dark at the apex, sometimes with a white space next below the apex, followed by a white spiral band: with, on the upper whorls, two, and on the lower whorls, three nearly equal spiral ridges, and many transverse slender ridges, the intersections being well developed nodules; anteriorly with two additional smaller less strongly nodulous spiral ridges: apex very acute: spire with the outlines nearly rectilinear : whorls about nine, planulate, with the place of the suture distinguished by a somewhat larger groove; last whorl terminating very abruptly : aperture suborbicular, rather small : canal short, nearly straight.

Mean divergence about $20^{\circ}$; length .11 inch; breadth .08 inch.

Ceritumm mirame. Shell ovate conic, turrited, sinistrorsal: white, with a sutural band of blackish brown, which commences a few whorls below the light brown apex with an intervening white space: with a narrow very prominent sutural ridge, on which is the band of blackish brown, and a stouter strongly nodulous spiral ridge along the middle of the whorls, anteriorly with one or two additional slightly nodulous spiral ridges: apex very tcute: spire with the outlines rectilinear in the upper half, quite fusiform in the lower half : whorls about fifteen, nearly planulate, with an indistinct suture; last whorl very much smaller than the penult whorl: aperture suborbicular, extremely small: with two small canals, which are deflected nearly at right angles to the axis of the shell, and are open only at the extremity. This extraordinary species of subgenus Triphora is remarkable for the minute size of the aperture.

Mean divergence to the penult whorl about $20^{\circ}$; length .2 inch; breadth .062 inch; length of aperture only .025 inch!

Cerrtuum exiguer. Shell long ovate conic, sinistrorsal: wax color: with, on the middle whorls, two, and on the lower whorls, three spiral ridges, of which the middle one is more slender, and numerous transverse ridges, the intersections being well developed nodules; anteriorly with three additional smaller less strongly nodulous spiral ridges: apex very acute: spire with the outlines most curvilinear along the middle, nearly rectilinear above and below : whorls ten, planulate, with the place of the suture distinguished by a somewhat larger groove; last whorl much smaller than the penult whorl, gradually tapering to the end: aperture rather small, subrhombic: canal very short, nearly straight. 


\section{9}

Mean divergence as far as the penult whorl about $17^{\circ}$; length .09 inch; breadth .035 inch.

Crimtuum internedur. Shell conoid, turrited, sinistrorsal: reddish black or dark brown, with a broad white spiral band on the lower part of the whorls; white near the apex: with, on the upper whorls, two, and on the lower whorls, three nodulous spiral ridges, and anteriorly three additional less strongly nodulous spiral ridges: apex acute: spire with the outlines rectilinear above, morlerately curvilinear below: whorls about twelve, planulate, with the place of the suture distinguished by a rather deeper groove: last whorl terminating rather abruptly: aperture rather small, obliquely obcordate: canal short, nearly closed at the origin, much deflected obliquely backwards. This species is intermediate between $C$. ornatum and $C$. modestum.

Mean divergence about $20^{\circ}$; length 2 inch; breadth .07 inch.

Cerithum versicolor. Shell ovate conic, turrited: usually mottled irregularly with reddish black and white, white prevailing on the varices and on the upper whorls, and the black on the lower whorls and especially on the granules; sometimes mostly white; sometimes mostly black: with numerous transverse ridges, which are prominent on the upper whorls; with, on most of the whorls, three spiral ridges, the intersections being developed into very prominent subacute nodules; and a fourth smaller spiral ridge in the suture of the last whorl; with intermediate spiral stria; anteriorly with four additional smaller less strongly nodulous spiral ridges and inter.nediary strie; with rather less than two irregular varices to cach whorl : apex very acute: spire with the outlines slightly curvilinear : whorls ten or eleven, a little convex, with a well impressed suture: merture subovate, rather acuminate at both extrenities : labrum rather sharp, very much thickened both externally and internally a little behind the edge, deeply striated within: labium with a small callus on the upper part: canal very short, rather wide, much deflected to the left.

Mean divergence about $26^{\circ}$; length of spire .42 inch; total length .57 inch; breadth .2 inch.

Cerituits megsoma. Shell long ovate conic : mostly brownish or reddish black, white within the aperture: thick, with three small spiral rather minutely granulous ridges, of which the upper two are 
lasger and more distant, and intermediary spiral strite ; anteriorly with six or seven additional feebly granulous small spiral ridges; often (?) with one broad varix on the left side: apex acute: spire with the outlines rectilinear except in the lower part: whorls about eight (?), a little convex, with a moderately impressed suture; last whorl large and rather ventricose: aperture subovate, rather acuminate at both extremities: labrum rather sharp, much thickened a little behind the edge, feebly striated within: labium with a small prominent callus above: canal very short.

Mean divergence nearly $40^{\circ}$; length of spire .36 inch; total length .53 inch; least breadth .25 inch; greatest breadth $.3 \mathrm{inch}$.

Centrnum gemsulosum. Shell conoid, turrited : reddish black, sometimes wax-colored on the lower part of the whorls: with three spiral ridges, of which the middle one is more elevated; and on each whorl about thirty-three small transverse ridges, with the intersections nodulous; with a fourth ridge which is slightly nodulous at the periphery of the last whorl, anterior to which are only incremental stria: apex acute: spire with the outlines moderately curvilinear : whorls twelve, moderately convex, with a well impressed suture; last whorl abruptly terminating, concave anteriorly; aperture broadly ovate: labrum very thin, well advanced along the middle: canal very short, nearly straight, wih a broad deep notch hehind.

Mean divergence nearly $30^{\circ}$; length of spire .17 inch; total length .21 inch; breadth .08 inch.

Cerithium rxile. Shell conic, turrited, very slender : brownish red, paler at the apex, whitish on the nodules: with one slightly elevated and three well elevated spiral lines, and on each whorl about twelve rather large obtuse ridges, the intersections being moderately developed into nodules; with another spiral well elevated line at the periphery of the last whorl: apex very acute: spire with the outlines rectilinear: whorls twelve to fourteen, quite convex, with a well impressed suture; last whorl terminating abruptly, concave anteriorly: aperture suborbicular : canal extremely short, reduced behind to a broad deep notch.

Mean divergence about $10^{\circ}$; length of spire .085 inch; total length .1 inch; breadth .03 inch. A fragment consisting of the lower five whorls of a larger shell is .04 inch wide.

Cектием fusmorme. Shell ovate-fusiform: reddish black, 
whitish at the apex, darkest on the ridges, paler between them and anteriorly: with, on most of the whorls, three spiral ridges, of which the upper two are nearer together and in the upper half of the shell are confluent, and of which the upper one is larger: with numerous scarcely perceptible transwerse ridges, which on the spiral ridges are excessively developed into closely set nodules; anteriorly with another subnodulous spiral ridge, and with transverse strix : apex acute : spire with the outlines curvilinear : whorls cight or nine, slightly convex, with an indistinct suture; last whorl nuch smaller than the penult whorl : eperture suborbicular : labrum well excurved and advanced, slightly thicliened : labium with a small callus above : canal very short, straight, wide.

Divergence in the upper whorls about $35^{2}$; length of spire .075 inch; total length .1 inch; breadth .04 inch.

Cerithum peichellum. Shell turrited, conic above, subcylindric in the lower three-fifths, conic above: snow white, with a spiral band of bright brown, which commences several whorls below the apex, and is placed on the inferior spiral ridge: with two spiral ridges, of which the upper one is larger, and is double on the lower whorls; with small transverse ridges, which are developed on the spiral ridges into rather large nodules; anteriorly with two other spiral ridges, of which the upper one is subnodelous : apex acute; spire with the ontlines slightly concave in the upper half and slightly convex in the lower half, often truncate with the loss of five whorls: whorls about eleven, a little convex, with a well impressed suture; last whorl a little smaller than the penult whorl, terminating obtusely: aperture suborbicular : labrum well escurved, moderately thickened: canal very short and wide, nearly straight.

Divergence in the upper whorls about $232^{\circ}$; length of spire $\mathbf{1 3 5}$ inch; total length .17 inch; breadth .045 inch.

Cremtnum regutosum. Shell conoid, turrited : white: with one slightly elerated and three much elerated tpirnl lines, and on each whorl about sixteen to eighteen transwerse rides, the intersections being well developed into nodules, anteriorly with a fourth spiril nodulous slender ridge: apex acute: spire with the nutlines nearly rectilinear: whorls about ten, quite convex, with a well impressed suture; last whorl terminating rather abruptly, sumewhat concave 


\section{โ122}

interiorly: aperture suborbicular : canal reduced almost to a brond deep notch.

Mean divergence abmut 1:30; length of spire .13 inch: total length .16 inch; breadth .055 inch.

Cermonum vicinas. Shell similar to C. rugulosum, but in place of the syiral lines are spiral ridges, and in place of the transverse ridges are slender transverse elevated lines, the propertion of size being reversed; whorls about eight or nine; the cant is a little more developed.

Mean divergence about $11^{\circ}$; length of spire .09 inch; total length .12 inch; breadth .04 inch.

Ceriturus ratum. Shell conic above, cylindric below : whitish, with a spiral brown band necupying the suture and the upper spiral ridge, on which however the grimules are whito: with three spiral ridges, of which the lwwer one is a little licrer, and very small transverse ridges, which are developed on the spiral ridges into very large nodules; anteriorly with an additional nodulous ridge: apex acute: spire with the wutlines quite curvilinear in the upper three-fifths: whorls seven, of which two are nuclear and smooth, slightly convex, with an indistiret suture; last whorl neariy as large as the penult whorl, terminating rather abruptly : aperture broadly ovate ; labrum well excurved, modenitely thickened: canal very short and wide, nearly straight.

Divergence in the upper whorls about $400^{\circ}$; length of spire .07 inch; total length .09 inch; breadth 038 inch.

Cerrtum flavum. Shell conic, turrited: bright yellowish brown: with three proninent spiral carinae, and about twenty-six less prominent transverse slender ridges, the intersections being feebly nodulous; anteriorly with an additional slightly nodulous spiral ridue: apex acule: spire with the outlines nearly rectilinear: whorls abont nine, a little convex, with a distinct suture ; last whorl termiuatiug very abruptly, coucave anteriorly: aperture suborbicular : canal extremely short, very wide.

Mean diversence near?y 30 ; length of spire .12 inch; total length .15 inch; breadth .045 inch.

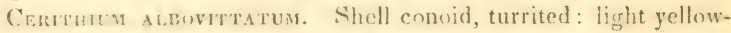
ish brown, whith a spiral white band occupying the two lower spiral ridges: wth three spiral ridges, of which the middle one is most 
prominent, and on each whorl about sisteen very small transverse ridges, the intersections forming well developed nedules; anteriorly with another slightly nodulous spiral ridge: apex acute: spire with the ontlines moderately curvilinear: whorls nine, a little convex, with an indistinct suture, last whorl terminating abruptly, concave anteriorly: aperture suborbicular : canal extremely short, wide, and straight.

Mean divergence about 24 ? ; length of -pire .09 inch; toial length .11 inch; breadth 035 inch. 



\section{CONTRIBUTTONS TO CONCIIOLOGY.}

No. 8 .

Descriptions of new species of Partela and Achatinelia, By C. B. Adass, Professor of Zoology, \&c., in Amherst College. Read before the New-York Lyceum of Natural History, Oct. 21st, 1850.

Partula minnets. Shell rather thick, ovate-conic; translucent, horn-colored, sometimes redlish, with a thin shining brownish horn-colored epidermis, which is much interrupted by transverse stripes; with the tip white; with unequal, irregular, rather coarse transverse striae, and numerous excessively minute impressed spiral lines; apex subacute; spire rather short, with the outlines slightly curvilinear; whorls five, a little convex, with a moderately impressed suture; last whorl moderately oblique: aperture rather small, subovate, with a tubercle on the middle of the intruding part of the last whorl: lip much thickened, but narrow, with a regularly rounded surface : umbilicus small.

Mean divergence $55^{\circ}$; length .63 inch; greatest breadth .36 inch; least breadth .3 inch; length of the aperture .23 inch: the corresponding dimensions of another specimen are $60^{\circ} ; .525$ inch; .28 inch; .32 inch; .21 inch.

\section{$\mathrm{Hab}$. — ?}

This species resembles a variety, ( $P$. auriculala Brod.,) or P. Otaheitana Brug., but is more slender, as well as smaller.

Achatrinela maxi. Shell thick, ovate-conic, elongate: blackish brown at the apex, reddish brown on the middle whorls, and ash-colored on the lower whorls: with unequal, irregular, very coarso transverse striac, with close-set transverse arcuate ribs near the apex, and some indistinet raised spiral lines on the lower part of the last whorl : apex subacute : spire rather long, with the outlines quite curvilinear: whorls soven, rather convex, with a well-impressed suture; last whorl 
obtusely angular: aperturo ovate, acute above, with an extremely thick deposit on the inner side, with a very large compressed columellar fold.

Mean divergence $50^{\circ}$; length 1.33 inch; breadth .7 inch : length of aperture .61 inch.

The unique specimen which has served for this description is somewhat faded, and the lip probably is not quite mature, being sharp.

Achatinella Tappaniana. Shell reversed, elongate ovateconic : pure white, with one narrow brown spiral band on the periphery of the last whorl: with very unequal and irregular transverse striae, and numerous excessively minute wrinkled spiral impressed lines: apex subacute: spire elongate, with the outlines a little curvilinear: whorls nearly seven, moderately convex, and more or less subangular, margined above, with a well impressed suture: aperture ovate; lip well thickened within the margin, expanded much anteriorly but not above; columellar fold strong.

Mean divergence $43^{\circ}$; length 1.06 inch ; breadth .55 inch ; length of aperture .44 inch.

Var. dubiosa differs in being a little more ventricose ; its whorls are not margined above, and the brown stripe is replaced by two fine paler brown lines, below which one or two other yet finer lines may be seen.

Habitat, Sandwich Islands.

This beautiful species is named in honor of Hon. Benjamin Tappan, of Ohio.

Acinatinella Dinondr. Shell reversed, thick, long ovateconic: dingy white or very pale yellowish brown, with a blackish margin to the aperture when mature; with a greenish black fugacious epidermis: with the transverse striae rather slight, very unequal and irregular, without spiral striae: apex subacute : spire rather long, with the outlines moderately 
curvilinear : whorls nearly seven, quite convex, with the suture well impressed; last whorl often somewhat flattened on the middle: aperture subovate, with the columellar fold well developed, with the deposit on the inner side very thin; labrum sharp, not reflected, well thickened within.

Mean divergence $45^{\circ}$; length 1 inch; breadth .5 inch; length of aperture .38 inch.

Variety (?) lala has a divergenee, in a specimen about two-thirds grown, of $55^{\circ}$.

Habitat, Sandwich Islands.

This fine species is named in honor of Mrr. Henry Dimond, of Honolulu, to whom I liave been much indebted for the shells of these islands.

Achatinflud pecepta. Shell rather thick, ovate-conic, much elongated: dingy white or very pale yellowish brown; with a dark brown or greenish epidermis, which is interrupted more or less in transverse stripes, and often terminates abruptly on the periphery of the last whorl: with irregular transverse striae; without spiral striae : apex subacute : spire long, with the outlines moderately curvilinear: whorls nearly seven and one-half, rather convex, with a well impressed suture; last whorl rather small: aperture small, ovate; lip sharp, not expanded, moderately thickened within; columellar fold moderately developed.

Mean divergence $39^{\circ}$; length .7.2 inch; breadth .33 inch; length of aperture 25 inch.

This shell is figured by Mr. Reeve (Icon. f. $42 a$, non $42 b$ ) as a variety of A. rubens Gould. We think it is entitled to specifie rank. It is usually more slender, and always more conical and less ovate, the last whorl being shorter, and not so regularly rounded, and the outlines of the spire being much less curvilinear. A. rubens, always retaining its more regularly rounded outlines, varies in its proportions in extreme 
varicties from .76 inch : .35 inch to .64 inch : .4 inch. The dimensions of Dr. Gould's type, .75 inch: .4 inch, are most common.

Acintinelata nodesta. Shell rather thick and short, ovateconic : dingy reddish or ash brown; more or less covered with a dingy dark brown epidermis : with fine irregular transverse striae, which are coarser on the upper whorls; without spiral striac: apex subacute: spire short, with the outlines quite curvilinear: whorls six, moderately convex, with a well impressed suture; last whorl rather ventricose : aperture ovate, somewhat acute above; lip sharp, not expanded, moderately thickened within; columellar fold well developed, quite oblique.

Mean divergence $50^{\circ}$; length .54 inch; breadth .3 inch ; length of aperture .26 inch.

The corresponding dimensions of another specimen are$47^{\circ} ; .55$ inch; .29 inch; 24 inch.

Habitat, Sandwich Islands.

Achatinelia Reevei. Although the name Achatinella radiate Pfi. appears in Dr. Pfeiffer's Hel. Monog. as a synonyme of A. vividans Migh., yet Mr. Reeve, in his beautiful monograph of this genus, has represented this species under the name of $A$. radiata, and has given another species with $\mathrm{Dr}$ Mighels' name. Dr. M. and myself about the same time received this very distinct species, and having seen it in his collection, I cannot doubt the correctness of Dr. Pfeiffer's synonymy. Some other specimens before me appear to be very exactly represented by MIr. Reeve's figure of A. viridans, and are most nearly allied to a group consisting of $A$. pulcherrima Swains., A. castanea Rv., A. abbreviata Re., Se. I propose for Mr. R.'s A. viridans the name which stands at the head of this paragraph. 
Descriptions of New SPECies aNd varieties of Syelds, which inhabit Janaica. By C. B. Adsiss, Professor of Zoology, \&c., in Amherst College. Read befure the New-York Lyceum of Natural History, Oct. 21st, 1850.

The following descriptions are in continuation of the CosTRIBLTIONS to Coxcirorogy, which were published by the writer in seven numbers, from Sept. 1819 to April 1850. They comprise the more important of the undescribed types of the land and fresh water slells of Jamaica, which are accumulating for a proposed monograph of the land and fiesh water shells of that island, and such of the marine species as are believed to be undescribed.

I take this opportunity to explain that three species of the land shells of Jamaica had received the names of persons, both in the original manuseript descriptions, and in labels with which specimens were distributed. But at the request of the late lamented Dr. Binney, whose name had been used, and who deemed it inexpedient to name species in this manner, other names for these species were substituted, as the article went to press. Unfortunately the first names, taken from the labels, were published by Dr. Pfeiffer. These are now supposed by some writers to have priority; but by attention to the dates, it will be pereeived, that the names published in the Proc. Bost. Soc. Jan. 1845, have priority. They were in fact published before the shells conld have been received in Europe. I can only regret having thus inadvertently caused the existence of synonymes. The following are the species:

Cyclostoma pulchrius Ad.; Syn. C. Binneyanum Pfr. Cylindrella nobilior (Pupa) Ad.; Fyn. C. Binneyana Pfr. Helix arboreoides Ad.; Syn. H. I Haldemaniana I'fr. In the same article, Achatina Griffithii was crroneonsly 
written A. Griffithsii. As this was merely an error in orthog. raphy, there can be no objection to the uso of the name as elsewhere correctly written.

In the following descriptions of operculated land shells, the opercula are not described, except when important for the diagnosis of the species. We agree with MI. Petit, (Journ. do Conch. 1850, p. 39,) who does not find in the opercula of $\mathrm{Cy}$ clostoma characters of sufficient importance to establish genera. Certainly they have not suficient intrinsic value, and it is yet to be shown that they are always expressive of generic differences in the soft parts of these animals. A similar opinion has been expressed by MIr. Redfield, in his catalogue of operculated land shells. Specific differences, however, are often well defined in the opercula.

Marginelda gracias. Shell between fusiform and eylindric, slender: white, with three spiral bands of orange brown, of which the upper one appears on the spire, a part of the middle one is seen in the deflection of the suture in the last part of the penult whorl; the middle band is sometimes indistinct : smooth and shining : apex rather obtuse : spire moderately lengthened, with the outlines quite curvilinear: whorls nearly four, moderately convex, with the suture not very distinct; last whorl long: aperture long and narrow; lip moderately thickened, slightly incurved; varix slightly extended on the penult whorl; with four very oblique plaits.

Length .26 inch; greatest breadth .09) inch; least breadth .075 inch; length of aperture .175 inch.

This species resembles II. arena Val., (II. varia Soub.,) but is much smaller, and much more slender, and has a longer spire.

Buccisust pulchfllum. Shell ovate fusiform: pale yellowish brown, with the spiral ridges dark reddish brown, ex- 
cept on the upper whorls : with twelve spiral prominent cordlike ridges, half of which appear on the spire, decussated by much less prominent regular transverse rilges, with the intersections well developed into modules: apex acute: spire with the outlines moderately curvilinear: whorls five, rather convex, with the suture moderately impressed; last whorl but little ventricose: aperture rather narrow and sinuous; lip slightly thickened, not denticulate within, (in old shells?) with the notch of medium size.

Mean divergence about $40^{\circ}$; length .145 inch; breadth .06 inch ; length of aperture .06 inch.

Of Pleurotome albelle Ad., (Cont. to Conch., p. 63,) a variety is wax-colored at both extremities, and has irregular spiral lines of the same on the lower part of the whorls.

Valvata incoxspicti. Shell subdiscoidal : pale horn color? with the striae of growth microscopic: spire convex, moderately elevated: whorls three, very rapidly increasing, with a deep canaliculate suture: aperture large, not much advanced above: umbilicus about half as wide as the penult whorl.

Greatest breadth .07 inch; least breadth .05 inch; height .04 inch.

Praxonuss mants. Shell suldiscoidal: color - ? with coarse striae of growth : apex and spire moderately depressed on the right side: whorls $t w o$ and one-half; last whorl with a very acute periphery nearly in the plane of the spire, moderately dilated around the umbilical region: aperture large, subtriangular, acutely angled at the periphery of the last whorl: umbilical region abruptly cxcavated, with the concavity about two-thirds as wide as the last whorl.

Greatest breadth .06 inch; least breadth .0 .15 inch; leight .025 inch. 
Probably the specimens before mo are immature, but tìe species is quite distinct from any other.

Of Planorbis dentiferus Ad., (Proc. Bost. Soc. Jan. 1, 1845, ) a variety occurs, which is destitute of teeth! After a careful examination of many specimens, I am unable to find any other differences constantly associated with this peculiarity. MIany of the toothless shells are more compressed obliquely just below the periphery, than the type, but the same is true of some of the shells in which the teeth are well developed. It is not a local variety, both kinds occurring together at Hatfield, in Westmoreland. The variety may be designated by the name EDENTatus.

Ancrius obriques. Shell subovate, somewhat arcuate, very convex : translucent, pale horn color: extremely thin, with microscopic radiating raised lines, and less distinct striae of growth : apex very prominent, clevated, extending very far to one side and posteriorly, and projecting nearly over the margin.

Length .075 inch; breadth .05 inch; height .028 inch.

This remarliable shell may belong to a new genus, but without the soft parts, it is difficult to determine the generic value of its peculiarities. The shell is hitherto unique in the rich collection of the Hon. Edward Chitty, to whom I am indebted for the loan of it.

Truncatella modesta. Shell much elongate, ovate conic : yellowish horn color, with a white upper margin of the whorls : with about twenty-one prominent compressed ribs, and numerous spiral striae, which are interrupted by the ribs: apex truncate with the loss of —— whorls : spire with the outlines somewhat curvilinear: whorls remaining after truncation seven, moderately convex, margined above : aperture subovate, slightly angulated anteriorly. 


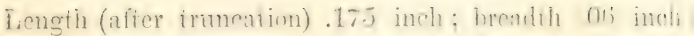
fengtl of aperture .045 inch.

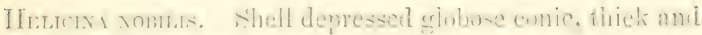
solid : white beneath and at the end of the late whort, otherwise rufous or dark brownish red : very storoth, the strine of

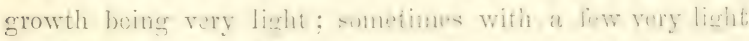
spiral striae : apex obtuse : spire enteves comio: whomk marly

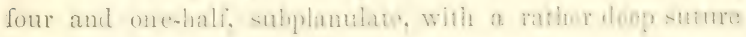
last whorl much depressed or even sinuate between the per-

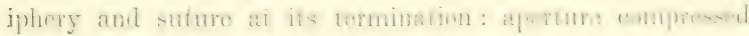

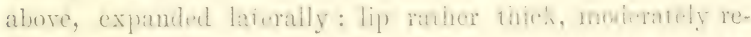
fleoted along the miduls only; with a notuh like thit of $\mathbf{l l}$. maxime Somb.

Mran divergence 1:0 : ereates brendils ..t imelı: least breadth .73 inch; height .55 inch.

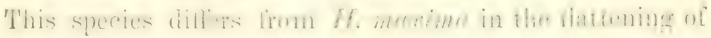

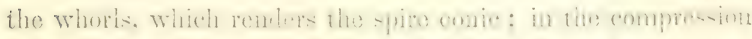

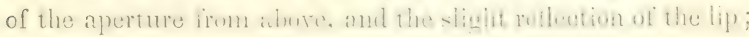
it is also more solid and less convex beneath.

Helicixa mirsuta. Shell depressed globose, rather thin :

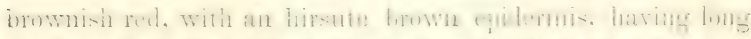

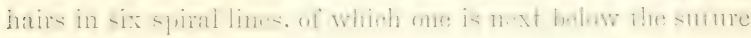
and the others are on the middle and lower parts of the last whorl: with the striae of growth lightly impressed: apex

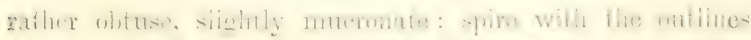

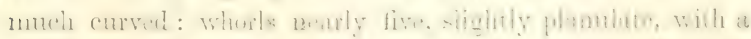

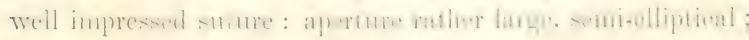
lip rather thin and sharp, but well rellected so as to form a canal behind; with the slit not very deep, but wide.

Mean divergence $110^{\circ}$; greatest breadth .59 inch; least breadth .48 inch; height . 0.1 inch.

The slit has about the same proportions as in II. Ifollowit, 
having ],as deptle and a greater wilth than in II. prolliate and H. Brownii. Except in its greater size, it very closely resembles the former species, which however wants the spiral line of hone hairs in the epmiermis. The apereulum of this

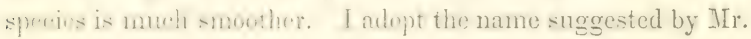
Chitty.

A variety of Helicina palliata occurs, in which the lip

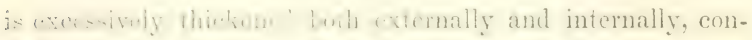
tracting the aperture. It may be designated by the name of LABross. It is a local variety. *

A variety of Helicina maxima is remarkable for its pale lemon yellow color; it may be designated by the name of

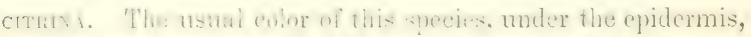
is the same as that of $I$ I. mulitis, (see above.) with less of white.

A variety of Helicina ampliate in the collection of Mr. Chitty is of a greenish yellow color, with a broad spiral band nearly covering the upper whorls, where it is dark reddish brown, occupying the lower part of the middle whorls where it is of a brownish slate color, and gradually becoming paler, and at length on the last whorl of a red color.

Helicina consanguinea. Shell subglobose, moderately thick: dark brownisls red, with the lip white; with a somewhat hirsute ephithmis. having the projecting points spirally arranged: with the striae of growth quite distinct: apex obtuse: spire with the outlines much curved: whorls five, moderately convex, with a well impressed suture : aperture semiorbicular; lip sinuous above, moderately thickened and sharp, but well reflected except at the extremities; with the slit broul and shallow.

\% Di: Hriland remarks, "The H. palliata found about here [Bethany, Man

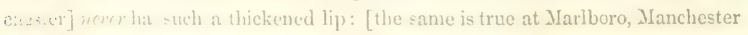
C. 13. A.] : but all the specimens from Maidstone (our station on the mountain oppo Eite to Bethany) are of this description?" 
Wean divergenes $110^{\circ}$ : orrateet wendth of inch: lenet breadth .05 inch; height .45 inch.

The slit, or noteh, as it might be called with equal propriety, is uniform in all the specimens before me. In this, as

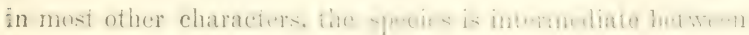
$H$. hirsuta and $H$. albolabris. It occurs in the parish of Westmoreland, the west part of the island.

Some specimens from the opposite extremity of the island, St. 'I'homas in the East, closely resemble H. consanguinea, except in having the aperture well dilated and rounded in the upper part, instead of being contracted by a sinus in the lip; they also have the noteh a little deeper, and the last whorl is a little more convex beneath. The sholl also is much like H. hirsuta, but the slit is not so deep, and the aperture is longer and narrower. I'hey present a distinct type, but I merely propose for it the name of soror, without deciding whether it be of specific value.

Helicina microstoma. Shell globose conic, moderately thickened: "brown, shaded off" to a smoky white along the suture" and on the periphery of the last whorl: with rather light striae of growth, in which are a few spiral series of punctures : apex obtuse: spire with the ontlines more or less and not uniformly curvilinear: whorls rather less than five, moderately convex, with a well impressed suture; last whorl subplanulate beneath: aperture semi-elliptical, compressed above and below, laterally dilated; with the lip sinuate, well expanded and reflected except at the extremities; with the slit not very deep, rather wide.

Mean divergence $60^{\circ}$; greatest breadth .65 inch; least breadth .52 inch; height .4 inch.

The slit is about as deep as in $H$. consanguinea, but the sides are less diverent. The pumete spiral series indionto spiral lines of hairs cul the endideruin. For two faded ypor- 
mons I ain intelfed to Wr. Molland. who has one froch shelf;

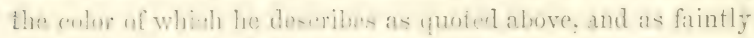
indiratud in the her of the speremens before me. In forth it

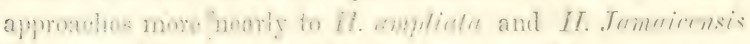
Than any of the wmonp, which is chameteriend by an anterion noteh or slit in the margin of the aperture.

I am indebted to MIr. Holland for a variety of Helicina de presen of atmondinary size. Lis mean divergence is 140 ;

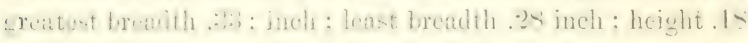

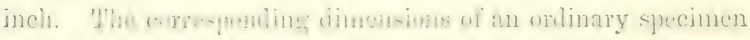
are $140^{\circ} ; .24$ inch; .2 inch ; .125 inch. It may be designated by the name of VALIDA.

A variety of Trochatella Joseplince, from the western part c! the juland, presuls a igyen quite listinet fiom that which

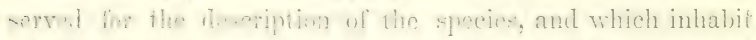
the wotem pere. The spiral rideres are lese ennspienous, and are more or less interrupted by various irregularities of the surface. The acute periphory is furnished with very prominent raulted compressed scales, and is of a red color. The

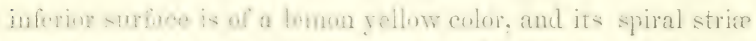

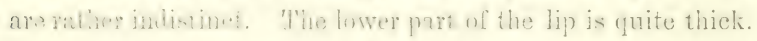
This type may be designated by the name of pulcira. Its

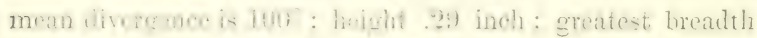
.52 inch; least breadth .44 inch.

Of Trochatella T'ankervillii several types appear quite

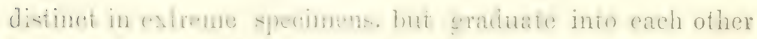

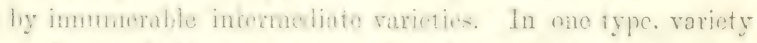
a. the ynimal rilgus are smuger, and the wher irregularities of surlare and te-s develonert. The last whorl is more convex on buth sules of the periphery, which is consequenty less acute.

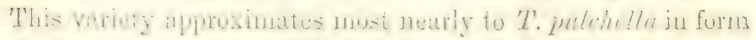
and size. 
In a second type, variety $\beta$, the sheils are more rugodens: scabrous, but thimner. 'They are nsually of small or medium size, and are the most richly colored. A nodification of this type sometimes occurs with a more elevated spire.

In a third type, variety $\%$, the seulpture is more like that of the first. but the outline is more angular, and the shell attains a great size. 'I'le colors are not as vivid as in variety $\beta$.

'The figure in sowh. 'Thes. (pl. I. (ig. 17) is more angular, and has a more clevated sire than any of the shells which J have seen.

The following are the dimensions of these varieties:

Var. $a$, mean div. $91^{\circ}$; height .53 inch ; great. br. .63 in. ; least br. .5 in.

$\begin{array}{llllllllll}\text { " }, 1, \text { " } & \text { " } 97^{\circ} ; & \text { " } & .51 & \text { " } & \text { " } & .67 \text { " } & \text { " } & .50 \text { " } \\ \text { " } & \text { " } & 90^{\circ} ; & \text { " } & .62 & \text { " } & \text { " } & .70 \text { " } & \text { " } & .56 \text { " } \\ \text { Fig. in Sowb.Thes. } 80^{\circ} ; & \text { "T } & .80 & \text { " } & .82 & \text { " } & \text { " } & .98 \text { " } & .80 \text { " } & .79 \text { " }\end{array}$

Crclostoma sagitureruir. Shell elongate, ovate conic: dingy white, with numerous inequidistant dark brown zigzag lines. with the fomr angles which are directed backwards arranged in spiral series on stripes of paler brown: with irregular transveres spots of darli hrown next below the suture: wile very crowded fine transwerse ridges, which intermpt minue spiral clevated lines: apex truneats. with the loss of - whols: spire rather lone, with the ontines currilinear: whorls remaining afee truneation four, quite convex, with a well impresed suture: aperture oblinuely ovate, with two peritremes: of which the onter one is molerately produced and not reflected posterioly, but in the rest part is well produevel, reflected nearly into the plane of the aperture, sinuous on the loft sile anterinly : inner pritreme thick, moderately producel. sliehtly reflected: umbilieus very narrow, extending through the truncate summit. 
For this species I am indebted to Mr. Chitty. It was found at Easington, in the parish of St. David's.

Tean divergenee about 45 ; length .96 inch after truncation; greatest breadth .6:3 inch ; least breadth .5.5 inch.

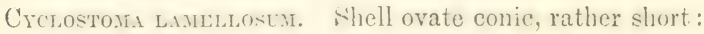
with sereral inequidistant mecinal more or less interrupted spiral lines of brown, of which four or five appear on the penult whorl : with rather closely set sharp elevated transverse lamellar, which are more proninent at the sutures; withont spiral striee, exeept a few ridges in the munbiliens: apex truneate with the loss of two or three whorls: spire with the outlines quite convex : about three and one-half whorls remaining, very convex, with a rather deep suture: aperture orbicular, witl two peritrenes, of which the outer one is narrow, auriculate above, refiected nearly into the plane of the aperture; the inner peritreme is rather stout, well produced, a little reflected. The operculum has a spiral lamella, which has about four and one-half whorls, and is but little elevated and mueh produced laterally.

Mean divergence about 5$)^{2}$; lengih after truncation .49 inch; greatest breadth .4 inch; least breadth .34 inch.

This shell much rescmbles C. teclilubre, but the outer peritreme is more expanded, and the margin of the operculum is not reflected backwards.

Crciostona snuturs. Shell long ovate conic : very pale brown or dingy white, with numerous spiral series of small dark brown spots, which are often elongate, and which are arranged in incyuidistant transverse stripes: with closely set rather strong transverse raised lines and indistinet spiral stria, moderately crenulate along the suture: apex truncate with the loss of - whorls: spire with the outlines moderately curvilinear : whorls remaining after truncation four or five, quite 
convex, with a weil impressed suture: apelture ovate orhienlar, with two preritremes, of which the outer one is moderately expanted and reflected nearly into the plane w the aperture; the inner one is mulerately produced and reliected : umbiliens very narrow, but extending through the truncate summit.

Mean divergenes about $37^{\circ}$; leneth after truneation .5t inch : greatest brealth .34 inch: least breadih .2:3 inch.

From Eaxington. At first sight this precies appears like C. Adumsi, hut is distingnished by leing less clongated, hy the spiral striæ, and by the double peritreme.

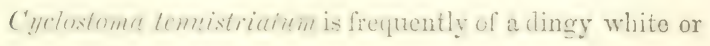
very pale brown color.

Cyclostoma modestum Ad. (Cont. Conch.)

A variety of c'yciostoma fimbirululum has the transverse ridges rather more numerous and regular than the type of the species, and at their intersection with the spiral ridges more or less developed into small mparue white tuhereles: its outer peritrene is not so wicie or seahouts, and is less strongly scalloped, and is less flatiened. Its size is less than that of the type of the speecies. It is a local variefy, wecturring in the eentre of Westmureland, the most western parish, while the typical ('. fimbriatulum oecurs lorty miles to the east, in Manchester, near the centre of the island. At the suggestion of Mr. Chitty, I propose for it the name of alminodatur.

Another variety of the same species inhnbits an intermediate region, the parish of St. Elizabeth's. Yet although geographiealiy iniermediate between the other two forms, it is by no means so in its characters. It is smaller than the var. albinotatum, has its peritreme narmver, and the transverse rilges are more numerous anil regular, in these characters diverging yot farther from the type of the speeics. On tho other hand, it diverges in the opposite direotion, having the 
fransverse ridges cross the spiral ridges with eniargeinent. We propose for it the name of alocens, in allusion to its instructiveness on the question of the origin of varieties.

A specimen of Cyclostome limcine from the mountains behind spanish 'lown is remarkable for its size and the development of the onter peritreme. Its dimensions are-mean divergence $54^{\circ}$; length 1 inch: greatest brealth .77 inch; least breadth . 6 inch : transverse diameter of the aperture .3 inch, and including the peritreme .57 inch !

On pages 91 and 93 of Contr. Conch. two varietie sof one species were accidentally published as distinet species, with the names of C. nolulosum and C'. granosum. These varieties differ slightly. The name. ('. granosum, having appeared in Mr. Redfield's catalogue, and being rather more appropriate, may be adopted to the exclusion of the other. Another variety of this species oceurs, in which the last whorl is much detached from the penult whorl. It is also entirely destitute of the purplish brown color anteriorly. The two individuals, which we have received on loan from Mr. Chitty, make us acquainted with the operculum of this species. It has a spiral lamella, well elevated, of moro than threo whorls. The variety may be designated by the namo of ABERR.ANS.

Analysis of the Group of strectis of Cyelostomu. Which is represented by C. Jamaicense Ciment.

This group has been more or less known for nearly sixty years under the name proposed by Chemnitz. In March. 1843, Mr. Sowerby, (Proc. Kool. Soc. Lond. and Thes. ('onch. I. p. 95, pl. 23, f. 10,11 , described a second species under the namo of C. corrugalum. Both species have been repeated. by Dr. Ifeitier in Kïuster's Cyclostomacea. During the press. 
ent year Mr. Sowerby has described a third type under the name of C'. subrugrosum, (Thes. Conch. I1. p. $16 \mathrm{~L}^{*}$, pl. suppl 31 B. f. 308, 309.)

Having found some difliculfy in identifying these speries, I concluded first to stumb the shells themselves and their upercalde, which are in my collectimn. Twenty types, which have seemed worthy of notiee, are described helow. L'erhaps two or three of these may be due to accitent or circunstances; but most of them are probahly orisinal types. Many of them are lneal. For the most part they are of less value than is usually assumed for a species.

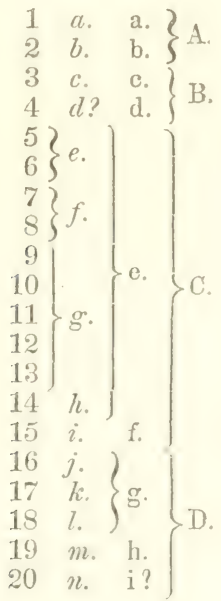

In the acempanying fable we have endeavored to express the athinities and values of the tygues. In the first columm the

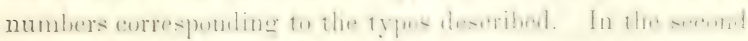

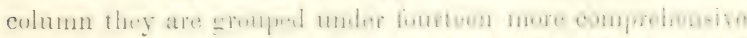
types, which are indicated by the italie letters. In the third 


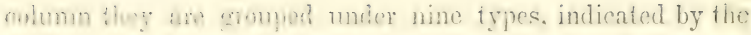
Luman letines and in the fourtis column, under fonr types, indicated by capitals.

Bquinatent on the whole ermup fins constitnted is a type, which appears in C' sulurale Soutb. In the former case, the

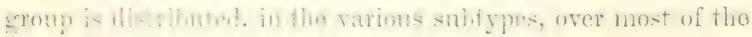
island. The latter occurs only in the western third of tho island, and is very uniform in its characters.

If, following the example of some, we should regard all

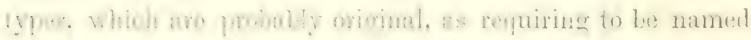
and described as species, we should soon be involved in an endless labyrinth. I'here would be not less than fifteen species in this group; the list of species of Cyclostoma inhabiting Jamaiea would be swelled to hundreds; and the terres-

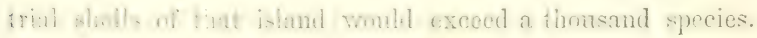
We prefer to treat species as we do genera, and endeavor to make them of as nearly equal value as the diversified system of nature will permit. We have deemed it useful to present. an illustration of tho actual scheme of nature.

The nine types of the third order, in the foregoing table appear to be of abont the mean value of ordinary species. It becomes necessary to assign them names. In the absence of the opereula, d and i may bo omitted as doubtful. MIr. Sowcrby's figure of the operculum of $C$. Jamaicensis accurately represents that of No. 18; and Tiuster's figure, the operculum of Nos. 16 and 17; all of which, notwithstanding some difference in the opereula, we had united in one species. MLost of our specimens are rather too coarsely sculptured to correspond with the figures given by these authors. Variety 16',

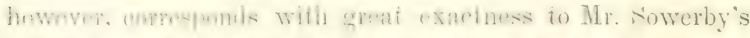

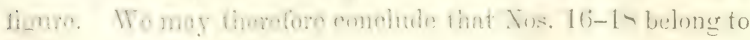
the Chemnitzian species. Our No. 1 approximates so exactly to Mr. Sowerby's figure of C. corrugatum, that we shall pro-

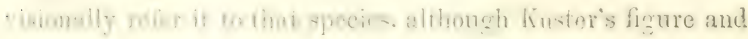


the descriptions of both anthors exchute an mobilioal bovil

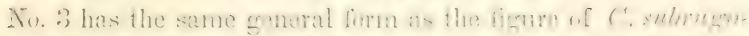
sum, but wants the umbilical leol. This species we ane num-

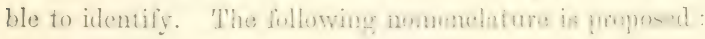

No. 1. Cyclostoma corrugatum? Sowb.

2. Cyclostoma jugosum Ad. sp. nov.

3. Cyclostoma pallescens Ad. sp. nov.

5-14. Cyclostoma varians Ad. sp. nov.

15. Cyelostoma seminudum Ad. sp. nov.

16-18. Cyclostoma Jamaicense Chem.

19. Cyclostoma crassum Ad. sp. nov.

It will be scen that we have made much use of the operculum. I'he differences of this part appear in this group to be more constant and better defined than those of the shell.

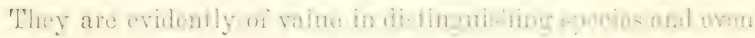

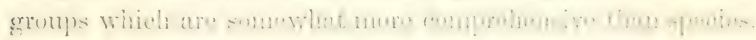
We would, however, with MI. Petit and MIr. Redtield, stop far

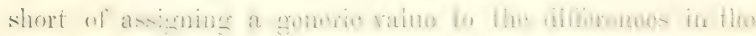
opercula of the groups of Cyclostoma.

No. 1. Shell reddish in tho upper whorls; in tho lower whorls palo horn color or dingy whito; with a brown epidermis: with deep transwerse somewhat wrinkled strix on all the whorls; foveately wrinkled, with shallow depressions; with a distinct umbilical keel, and largo curved pits exterior to the keel : spire well elevated: whorls nearly five, flattoned on the upper part, with a well impressed suture: aperture suborbicular, quito eftisse and pointed above; lip sinuato above, much advanced along the middle of tho right side, moderately thickened: umbilicus a little moro than half as wide as the aperture. Opercultum with a much elevated spiral lamella in nino whorls, which are much inflected curvately, the outer surfaco being convex, like tho sides of an inverted saucer.

Mean divergenco $120^{\circ}$; height .55 inch; greatest breadth . 88 inch; least breadth .69 inch.

No. 2. Shell white, with a light bromn epidermis: with rather deep transwerse striæ, which are very regular on the upper whorls, and very irregular on the last whorl; with deep wrinkles commencing near tho end of the pemult whorl, whero they are somewhat regular and oblique, as they aro also on the lower side of the last whorl, on tho upper sido of which they are irregular and knotty; the umbilical keel is obsoleto: spiro much depressed: whorls nearly fivo, well rounded, with a 
doeply impresseci suture: aperture orbicular, slimhtly eftuse and pointed above: lip scarcely sinuato above, much advanced along the middle of the right side, moderately thickened: umbilicus four-fifths as wide as tho aperture. Operculum with a much elevated spiral lamella, in seven or eight whorls, which are much inflected but not so curvately as No. 1 .

Mean divergence about $145^{\circ}$; height .6 inch; greatest breadth 1.08 inch ; least breadth .85 inch.

No. 3. Shell with the spire brownish red, and the last whorl white; with a brown epidermis: with the transverse strix fine and regular on the spire, and very irregular on the last whorl; with fine wrinkles commeneing above near the end of the penult whorl; last whorl very coarsely and irregularly wrinkled above, nearly or quite smooth beneath; the umbilical keel is obsolete: spire depressed: whorls nearly five; last whorl flattened above; with the suture moderately impressed: aperture orbicular, slightly effise and pointed above; lip scarcely sinuate above, moderately advanced on the right side: umbilicus about two-thirds as wide as the aperture. Operculum with a much elevated spiral lamella, the whorls of which, six or seven in number, are saucer-shaped; that is, reflected, with the inner surface concave: the lamella is like that of No. 1 inverted.

Mean divergence about $145^{\circ}$; height .67 inch; greatest breadth 1.15 inch; least breadth .91 inch. No. 3 ' differs in having tho lower part of the last whorl finely wrinkled.

No. 4. This resembles No. 3 , but the wrinliles on the last half of the last whorl are somewhat regular, oblique, and very large: the umbilical keel is well developed: the umbilicus is only half as wide as the aperture. The operculum is unknown.

No. 5. Upper whorls horn color or light red; lower whorls white, with a brown epidermis: with the transverse striæ rather fine and irregular; wrinkles commeneing on the antepenult whorl, regular, oblique and well defined on the penult whorl, sometimes regular on the lower part of the last whorl; umbilical keel well developed: spire somewhat depressed: whorls about four and one-half, scarcely flattened above, with a well impressed suture: aperture orbicular, slightly effuse and pointed at the junction with the penult whorl; lip rather thin, slightly advaneed in the right side: umbilicus two-thirds as wide as the aperture. Operculurn with a spiral lamella of abont eight whorls, with the upper margins reflected and expanded so as to be nearly in contact.

Mean divergence about $135^{\circ}$; height .55 inch; greatest broadth .9 inch ; least breadth .72 inch.

No. 6. White, often reddish above; with a brown epidermis: with the transverse strix extremely fine, somewhat regular on the upper whorls; wrinkles commencing on the antepenult whorl, fine, regular and oblique on the penult whorl and at the beginning of the last whorl, on the rest of which they are fine and irregular: umbilical keel well developed: spire well elevated: whorls five; last whorl slightly depressed above ; suture well impressed : aperture sutorbicular, quite effuse and pointed above; lip well thickened, moderately advanced on the right side; umbilicus about three-fifths as wide as the aperture. Operculum slightly concave, with a thick spiru! lamina en seven or eight whorls, the upper part of which is $6 x$ - 
panded in both dirertions but mostly on the exterior, and is then curved dorrnwards, presentiug a broad rounded summit. A transverse section of the lanina somewhat resembles tho italic letter $T$ ?

Mean divergenco about $120^{\circ}$; height .46 inch; greatest breadth .84 inch; least breadth .65 inch.

No. 7. This differs from No. $6:$ the depression of the last whorl above is rather deeper, and,extends along the penult whorl whero it is linear; the wrinkles are less regular, and are often wanting at the end and lower side of the penult whorl ; the umbilicial keel is very strongly developed; the epidermis is very dark brown; in the whorls of the opercular lamina, the lateral expan-ions come in contact, forming a covered way luneath. This type inhabits the parish of Portland. It attains a great sizo and solidity.

Mean divergence about $120^{\circ}$; height .85 inch; greatest breadth 1.36 inch; least breadth 1.05 inch.

No. 8 differs from the preceding, in having the whole surface destitute of wrinkles.

No. 9 is also like No. 7 ; but its operculum is flatter, and has two more whorls, and all its whorls are therefore narrower; tho epidermis is light brown; and the wrinkles are nearly wh-ulete, exeept a faw which are small and well defined near the commencement of the penult whorl.

Mean divergence $130^{\circ}$; height .6 inch; greatest breadth 1.03 inch; least breadth .81 inch.

No. 10. 'The wrinkles are well developed, rather sharp, oblique and regular on the penult and antepenult whorls, and aro nearly obsolete on tho last whorl, the lower side of which is quite smooth; the umbilical keel is very prominent; the operculum is like that of No.9. Some have a few raised spiral lines on the last whorl.

Mean divergence $125^{\circ}$; height .55 inch; greatest breadth .95 inch; least breadth .75 inch.

No. 11. White, often reddish; the epidermis is dark brown, with a while stripo next below the suture on the last whorl : with the transverse strix excessively minute: the wrinkles are rery small on the antepenult and penult whorls, and nearly obsolete on the upper part of the last whorl, which is smooth below; there are a few indistimet spiral stria : the umb lical heel is well developed : spire well elevated: whorls nearly five, slightly depressed above; with a well impressed suture aperture sulvorbicular. quite pointed atud ethise atove : lip well thickened, much advanced on the right side: umbilicus half as wide as the aperture. Operculum like that of No. 9.

Inhabits St. John's.

Hean thwrence ahout $1: 20^{\circ}$; height .55 inch; greatest breadth .92 inch; least breadth .74 inch.

No. 12 ditiers frem No. 11 in having the whorls more flattened above, and the aperture more dilated. Operculum as in No. 9.

Inhabits the north side, in St. Mary's. 
Sfean divergence about $135^{\circ}$; height .57 inch; greatest breadth .99 inch; ieast breadth .76 inch.

No. 13. Brownish red in the upper whorls, white in the last whorl; with a brown epidermis: with the transverse strix quito fine; foveate wrinkles commencIng in the latter part of the penult whorl, and becoming obsolete in the latter part of the last whorl ; with some lightly impressed spiral strie on the last whorl : umbilical keel moderately developed; spire moderately elevated: whorls nearly five ; penult whorl flattened and last whorl much depressed above; with a woll impressed suture: aperture orbicular, advanced above in an acuto effuse point; lip sinuato above, moderately thickened: umbilicus abont two-thirds as wide as the aperturo. Operculum unknown.

Mean divergence about $130^{\circ}$; height .7 inch; greatest breadth 1.15 inch; least breadth .93 inch.

No. 14. White, often more or less reddish; epidermis dark brown, sometimes paler and greenish; with a band on the periphery, and a very narrow one at the upper edge of the last whorl: with a few indistinct wrinkles on the last whorl near the suture; transverse strix very fine; umbilical kecl well developed with age: spire well elevated: whorls nearly five, very convex; last whorl with a slight depression above; suture well impressed: aperture suborbicular, quite effuse and acute above; lip well thickened, a little sinuate above, moderately advanced on the right side: umbilicus about twp-thirds as wido as the aperture. Opcrculum with a spiral lamella of about five whorls, of which the inner whorls are a littlo inclined inwards, and the outer ones shelve inwards and are much thickened.

It inhabits Accompongtown, in the interior, in St. Elizabeth's purish.

Mean divergence about $120^{\circ}$; height .5 inch; greatest breadth.73 inch; least breadth .58 inch.

No. 14' has a bright red spiro, and on the last two whorls numerous minute wrinkles, which are indistinct about the periphery of the last whorl; without the white bands. Operculum unknown.

No. 14" is intermediato between 14 and 14.

No. 15. Shell brownish orange or brownish on the spire, reddish white on the last whorl; with a brown epidermis, which on the last whorl is mostly limited to two or three dark brown broad well defined spiral bands, which are often confluent $\mathrm{n}$ one: with the transverse striæ very fine; wrinkles commencing about the middle of the penult whorl, mostly foveate; last whorl very irregularly wrinkled above, with minute pits exterior to tho well developed umbilical keel, otherwise smooth: spire well elevated: whorls nearly tive, with a slight depression at the top of the last whorl; with the suture well impressed: aperture suborbicular, quite effuse and pointed above; lip thick, a little sinuato above, and well adranced on the right side: umbilicus about three-fourths as wide as the aperture. Operculum quite concave, with the spiral lamella scarcely elevated, but much thickened and appressed on the exterior side.

Inhabits Manchester.

Mean divergence about $120^{\circ}$; height .65 inch ; greatest breadth 1 inch; least breadth .79 inch.

No. 15 is more wrinkled and much smaller, its greatest breadth being . C. mech. 
No. 16. More or less reddish, often with a white stripe at the upper edge of the last whorl; with a brown epidermis, which is more or less interrupted by na. ked spiral stripes, which aro often numerous: wrinkles commencing in some be. fore, in others after tho end of the penult whorl, in some, narrow and well defined, often nearly obsolete, especially on the back of the last whorl; transverso strix fine but rather deep; rarely a littlo wrinkled near the umbilical keel, which is well developed: spire well elevated: whorls and aperturo as in No. 15: umbilicus about half as wide as the aperture. Operculum with a spiral lamella of six or seven whorts, modiately sloping outwards, with the ulper margin moderately reflected externally:

Mean divergence about $120^{\circ}$; height .68 inch; greatest breadth 1.0.1 inch; least breadth .83 inch.

In No. $16^{\prime}$ the wrinkles are obsolete.

No. 16" has the wrinkles mostly on the penult whorl.

No. 17. Shell whito with moro or less reddish, pure white on the last whorl next the suture; with a rich brown epidermis: transrerse strie rather coarse; wrinkles minute but well defined, occupying more or less of the last whorl ; umbilical keel well developed : spire much elevated: whorls five and one-third; last whorl moderately depressed abovo ; suture well impressed: aperture large, suborbicular, somewhat acute abovo; lip rather thin, slightly sinuated below by the umbilical kecl: umbilicus half as wide as the aperture. Operculum a little concave; spiral lamella with seven or eight whorls, rather wide, curvately reflected, but not concealing the intermediate space.

Mean divergence about $110^{\circ}$; height .9 inch; greatest breadth 1.08 inch; least breadth .87 inch.

No. 18. Shell whito with a greenish brown epidermis, or reddish with a dark brown epidermis: with the transverse strix extremely coarso; with irregular coarse but not deep wrinkles on the upper part of the last whorl; with some more or less distinct striæ on the last whorl: spire well elevated: whorls about five and onethird, scarcely depressed above, witl a well impressed suturo: aperture large, suborbicular; effuse, pointed and advanced above; lip slightly sinuate above, moderately thickened; in the whito variety thin and sharp on the right side: umbilicus a littlo moro than half as wido as the aperture. Operculum flat; lamella with six or seven distinct whorls, rather narrow, moderately reflected.

Inhabits the middlo parts of Manchester.

Jean divergence about $120^{\circ}$; height .88 inch; greatest breadth 1.23 inch; least breadth 1 inch.

No. 18 is probably an accidental variety, with tho last whorl deflected below

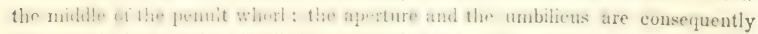
contracted: in tho other details it agrees with the type.

No. 19. Shell whito with a brown epidermis : with deep transverse strix; with indistinct spiral strix; not wrinkled; umbilical keel obsolete: spire moderately elevated: whorls five; last whorl scarcely depressed above; suture well impressed : aperturo suborbicular, eftuse, pointed, and advanced abovo: lip well thickened: umbilicus nearly two-thirds as wide as tho aperture. Operculum rather concave; lamella with about seven whorls, of medium width, nearly perpendicular except that the thickened upper margin is moderately reflected. 
Inhabits the back parts of Manchester.

Hean diverance about $130^{\circ}$; height .53 inch; greatest breadth $.7 \mathrm{inch}$; least breadth $.62 \mathrm{inch}$.

No. 20. Shell white, reddish on the upper whorls, with a pale greenish brown epidermis: transverso striœ very fine, wrinkled; with minute wrinkles nearly covering the last whorl; umbilical kecl wanting: spire moderately elevated: whorls five; last whorl flattened beneath, making the periphery subangular; with the suture well impressed: aperture suborbicular : effuse, pointed, and moch adranced above; lip thick: umbilicus half as wide as the aperture. Operculum unknown.

Mean divergence about $130^{\circ}$; height .45 inch; greatest breadth . 7 inch; least breadth .58 inch.

Note on the genus Stonstona. Following the suggestion of Dr. Pfeiffer, (Zeitschr. Malak. 1849, p. 113.) I recognize the grenus Strastoma in the well-known Cyclostoma succineun Sourb. It appears to me, however, that Dr. P. has gone too far in saying that this sipecies may be talien as the chief type ("Haupttypus") of the new genus. It differs from all the species of Jamaica, in having the labrum sharp and not produced beyond the labium, in the manner which suggested the name of the grenus. Storstomer succineuin might therefore be considered as the type of a Polynesian subgemus, which has about the same degree of affinity to Stoastoma proper, that Partula has to Bulimus.

Stoastoma Tilkixsoniz. Shell subdiscoidal: pale horn color, subtransparent: with five spiral carinæ, of which one runs into the suture, and one appears on the middle of the whorls of the spire; some have, in place of the last one, two smaller carine; with very delicate spiral raised lines, usually four to six in each interspace: spire moderately and convexly elevated: whorls three and one-half, angulated, with a deep suture; last whorl rather large, detached from the penult whorl near the aperture : aperture campanulate; labrum produced very far, above abruptly produced and aurienlate, with wile and deep scallops formed by the produced carina ; labium much detached from the penult whorl and a little reflect- 


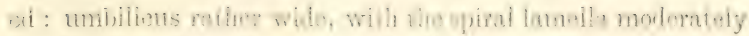

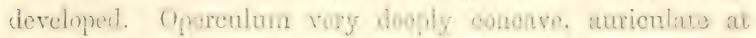
both extremitios, very finoly punctulato.

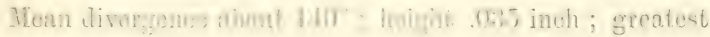
breadth .07 inch; least broadth .055 inch.

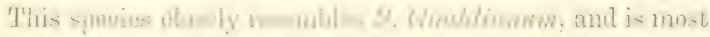

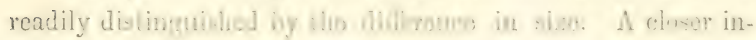
spection will detect the more essential diferences.

Stonstoma Thipamanum. Shell subdiscoidal: pale horn color, sabtransparont: with seyon apiral omine. of which the npper ons is sinali arul the lewer sebs vory minut.. and of which iwo are victhles ans the ungue whewles with very deli-

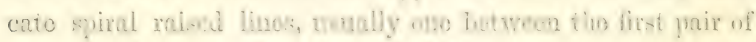

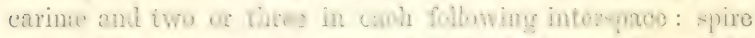

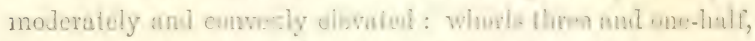
moderatoly emvax, with a deop : utare; lase wharl searedy

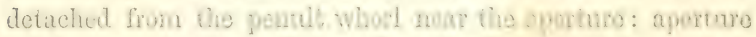

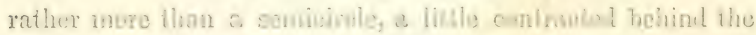
labrum, whill is well preduod, aimve rullere abruplly prodnced, scarooly molibed by tho canino; folitum muth detached from the pruall whor and a lithe reflected : umbilieus rather wide; with the spimb tamedla bolemuly devedopal.

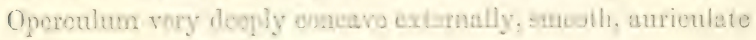
at both extremitics.

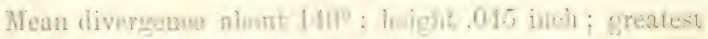
breadth .086 inch; lcast breadth .07 inch.

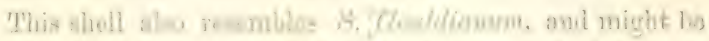

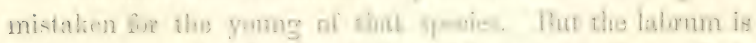

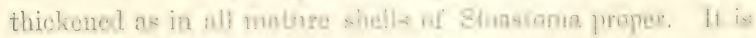
mo-i readily distinguisited from that mpocks by the peculiarities of the aperture.

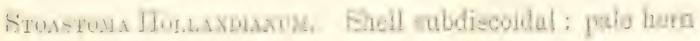


color, subtransparent: with five-piml carina", one of which is visible on the spire: with very delicate spiral raised lines, u-ually three to six in cach incer-paes: spire molerately clevatel convex: whorls throe and on -half nmberately convex, subangular; with a well inyme-sod suture : last whorl scarceIy detachnd from tho pomult wherl at the aporture: aperture rather lares, sighty constrioted behind the lip, which is mod-

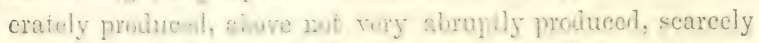
modifud by the earine; labiam well detached from the penult whorl, searcely rollontenl: umhiliens rather wide, with the siral lanella molerewly developed. Operculum deeply concave, subauriculate, smooth.

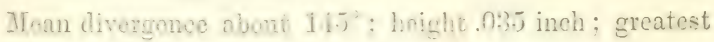
breadth .065 inch; least breadth .055 inch.

This smeies mude ressmbles the meeraing. It is most readily distinguished by its inferin sizo, and by the greater number of fine spiral striæ.

Sroistoma Montcammamum. Shell globose conic; hom color, or very palo yellowith reen: with numerous very fine somewhat tortuous raich s jiral lines, of which three or four are visihle un the spire; and two or three still more minute lines in cach interopace : bat in sme, all the lines are nearly equal : spire well clevatal, with the ontlines nearly rectilinear: whorle four, quite convex, wilh a well impresed suture; last whorl subghowe: apteture inther larger than a semicircle, a litile campanulate : labrum moverarely and ahove not abruptly proluecel, sareety madiand ly tho lurger spiral lines: labium molerately defached from tho penult whorl, slightly curved and rellectod: umbilicus nurrow, with the spiral lamella very small. Giperculum rather deeply cumeave, subau riculate, very finely papillose.

Nean dirergence about $5.5 \%$; height .075 inch; greatest breadth .085 inch; least breadth .075 inch. 
This species resembles S. Redfieldianum; but the shell is larger, the spiral lines are smaller, and the spire is larger in proportion at the last whorl.

Stoastoma Petrtiancar. Shell between globose and discoidal : dingy white: with eight or ten raised slender spiral lines, of which three or four are visible on the spire, and as many others which are more minute: spire moderately elevated, convex: whorls three and one-half, moderately convex, with a lightly impressed suture; last whorl well rounded: aperture much contracted behind the labrum, which is but moderately produced, and is double, with the outer margin scarcely modified by the larger spiral lines; labium moderately detached from the penult whorl : umbilicus rather small, with the spiral lamella but moderately developed.

Mean divergenco about $125^{\circ}$; height .04 inch ; greatest breadth .06 inch; least breadth .05 inch.

Stonstoma Antmonianum. This shell is like the preceding; but the spire is much depressed; the spiral lines are rather stronger; and the aperture is very campanulate, the labrum being very much produced before the deep constriction.

Mean divergence about $145^{\circ}$; height .035 inch; greatest breadth .07 inch; least breadth .055 incl. 



\section{CONTRIBUTIONS TO CONCHOLOGY. \\ IV. 9.}

[From Annals of N. Y. Lyceum of Natural Hist. Vol, F. No. 3.]

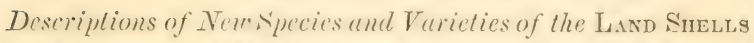
of Janarca, wilh Wotes on some previously described species. By C. B. Adnus, Professor of Zoology in Amherst College, Massachusetts. April, 1851.

'I'he writer has reently spent some time in Kingston, Jamaica, in arranging the land shells of that island, which are in the collections of the Ionorable Edward Chitty, and in selecting from them materials for the propesed monograph of Jamaica shells. Anong them are several new species and varieties, which have recently been obtained by ITr. Chitty, and which, with some previously known, are described in this article.*

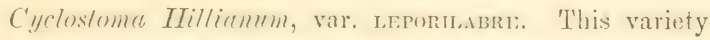
is distinguished by having an abrupt reflection of a small part of the outer peritreme next above its comtact with the penult whorl. 'The outer peritreme is also very much expan.led, and is somewhat sinuate above.

Cyclostoma spinulosum (p. 1 of Contributions to Conch.) is perhaps identical with $C$. lincinellum, Lam., if we may judge from the figures of Lamarck's species in Kuster's "Cyclostomacea."

Crcenstoma Moussonianust. Shell short, globose-conic: dingy white, with numerous more or less inferrupted spiral redulish brown lines: with more or less crowded transverse subimbricate lamellæ, which are decussated by numerous small spiral ridges, with the intersections well developed into spines in the angle of the suture: spire with very convex outlines; apex usually truncate with the loss of two whorls; re. maining whorls three and one-half, very convex; last whorl a little detached from the penult whorl near the aperture, but

* This and the following articles were prepared ly the writer while in Kins-ton.

No. 9-1. 


\section{5) Descriptions of New Specics and Varielies of Shells,}

soldered to it by the outer peritreme : aperture circular; inner peritreme moderately produced; outer peritreme much expanded, and reflected very convexly back of the plane of the aperture; imbricate, slightly and finely scolloped: unbilicus not very wide, extending through the truncate apex.

Mean divergence about $75^{\circ}$; length .54 inch; greatest breadth .53 inch; least breadth .38 inch.

Opereulum very convex, very closely striated obliquely, with the spiral lamella moderately raised.

This shell closely resembles C. spinulosum, except in the outer peritreme and in the opereulum, which widely distinguish it from the allied species. 'The operculum, however, somewhat resembles that of $\mathrm{C}$. anomalum, and the lip is like that of C. retrorsum.

The species is named in honor of Professor A. II. Mousson of Zurich, Switzerland.

Cyclostoma amandum (p. 3 of C. C.) is probably identical with $C$. scabriculum, Sowb.

Cyclostome virgincum (p. 90, C. C.) is identical with $C$. pisum (p. 9.)

Cyclostoma concentricum (p. 4, C. C.) is not sufficiently distinet from C. variabile (p. 3, C. C.) to take a higher rank than that of a variety.

Crclostona mutatum. This name is here proposed for $C$. arliculutum Sowb. inasmuch as Gray in Griffith's Cuvier $(1-36)$ had already applied the latter title to a species afterwards known as C. filosum Sowb. Sowerby's C. urticulatum was not established until 1-13, and nust therefore be dropped.

Cyclostona Campeelif. Shell elongate conic: color ? with numerous transverse moderately elevated lanellex : apex acute: spire not truncated, with the outlines but little convex: whorls six and onc-half, quite convex, with a rather deep suture; last, whorl at the end much detached from the penult whorl, and angular above: aperture nearly cireular, with the 
inner peritreme moderately produced, and the onter peritreme small and expanded into the plane of the aperture: umbilieus small.

Mean divergence about $40^{\circ}$; lenerth .36 inch; greatest breadth .2 inch; least breadth .16 inch.

For this and several other new and interesting species wo are indebtad to Archibald Campbell, Ksu., of New Hope, Wrestmoreland.

Cyclostoma anthostome and C . immilube have whitelipped varieties, each of which may be dexignated by the name ALBilabire.

Cyclostoma proximum (p. S, ( . C.) is perhaps only a variety of C. fascia, Gray.

Cyclostome nitens (p. S, (.. ( :.) appears to be comnected with C. Aususte: (p. 7, C. C.) by intemediate specimens, and is probably only a variety. Another variety of ('. Augustae may be designated by the name of Tristedinex. Its seulpture is more prominent, and the color is more or less like burnt umber. It approximates towards C. fascia.

'The rufous or red lipped varieties of ('yclostomu. Juyanum

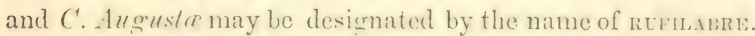

Crelostona Chevaner. Shell ovate ennic: hrown, darker at the summit, white along the suture, aromed the mubiliens, and with the peritreme white; also with several spiral series of dark brown dots, of which series two on the upper whorls and three on the last are most conspicums: smooth and shining: spire rather convex, truncated with the loss of more than two whorls: about four whorls remaining, which are quite convex, with a molerately depressed suture: aperture nearly circular : the imner peritreme slightly leveloped ; outer peritreme smooth and widely expanded, (especially above and on the left sile.) well appresed to the penult whorl: umbilicus very small.

Mean divergence about, 4$)^{-2}$; leneth . 6s inch; greatest breadth .48 inch; least breadth .35 inch. 


\section{Descriptions of New Species and Varieties of Shells,}

The operculum is similar to that of $C$. album, being subspiral, with oblique striæ.

Variety ALiscir wants the dark brown color, and has the spiral dotted lines more or less indistinct.

Variety virgatum is dingy or pearl white, with the spiral dotted lines conspicuous.

This species is named in honor of the botanist MI. Chevalier.

Cyclostoma album, var. Fiscrur, is distingnished by its smaller size, brown color, and a less smooth surface:

Cyclostoma Yallahense. This species resembles C. hyacinthimum (p. 9), which is probably identical with C. Banlisianum Sowb. But it is smaller and more slender; the color is bluish brown, and does not change by age or exposure into orange near the aperture; the strixe are coarser; the othlique indentations are often obsolete. The operenlum is similar to that of C. hyacinthinum.

Mean divergence about $46^{\circ}$; length .48 inch; greatest breadth .32 inch; least breadth $.27 \mathrm{inch}$.

Although this shell so much resembles the species with which we have compared it, a peculiar type is easily recognized in it. The two types are geugraphically remote; this species inhabiting the east end of the island from Yallahs' Hill eastward, while the other occurs in the middle of the south side (IIanchester) and westward. Neither species has been found in the intermediate regions.

Cyclostona sericinus. Shell much elongated, conic: silky white, with four spiral series of brown dots, of which three appear on the spire; around the umbilicus is a fifth series less distinct: with crowded regular transverse obtuse fine raised lines: spire with the ontlines moderately convex, truncated with the loss of two whorls; whorls remaining fur and one-half, quite convex, with a rather deep suture: aperture slightly detached from the penult whorl; inner peritreme in- 
distinct; onter peritreme moderately expanded, except on the left side, which is not reflected: umbilicus small.

Mean divergence about $3{ }^{\circ}$; lenghl .6: inch; greatest breadth .36 inch; least breadth .26 inch.

Inhabits New-Hope, Westmoreland.

('reosoma 'Tappaxism. Shell elongate conoid: brownish orange, with a paler band below the periphery of the last whorl, with the coltumella brown: with erowded strong transverse strier, and less stronely impressed spiral strie : spire with the ontlines moderately convex, truneated with the luss of — whorls; remaining whorls four, slightly convex, with a moderately impresed suture: aperture ovate, acute above, with the margin not reflected hut sharp): unbiliens indistinet.

Mean divergence about $30^{\circ}$; length .41 inch; greatest breadth .2 inch; least breadth. 18 inch.

Named in honor of the Hun. Benjamin Tappan, of Ohio. This species was fomm in a lot of Jamatea shells in the collection of R. G. Marshall, Esq., of Morant Bay.

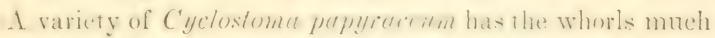
abbreviated; the last whorl is more atruptly romolul, and the aperture is consequently shonter. It may be cailed smbritiTEג.

Crclostoma perpaldidus. This name is given to "No. 20," draviled on page 1.4. Javing seen a consilemble number of specimens, all of which very exactly enineite in the in characters, I can no lonerer hesitate to regand it as a good species, although the operculum is yet unknown.

Crclostoma dubiosum. This species differs in one very striking character from C'. salurele suvbl): it wants the keel next below the snture, in the place of which there is a depression of the mpler part of the whorls. The have seen several specinens of this species and many of C'. suturale, and all of then conform exactly to their respectire types. When the opereulum of C'. dubiosm shall have been fouml, additional peculiarities may be discovered. 
S'rossmour P'mupruxt. Shell sulydiscoidal, convex above: pale horn color, subtransparent: surfice smooth and shining: spire molerately and convexly elevated: whorls three and onehalf, slightly convex, with a molerately impressed suture; last whorl regularly rounded over the periphery, very slightly detached from the penult, whorl near the aperture: aperture slightly campanulate: labrum slightly produced beyond the labium, not scalloped: labium in its upper half a little detached from the penult whorl, with the lower half extending below the penult whorl: umbilicus of moderate size, with the spiral lamella excessively developed and usually soldered by its exterior edge to the last whorl, forming over the umbilicus a large areh, which has an opening rather larger than the aperture of the shell. Inhabits Aekendown in Westmoreland.

Mean divergence about $130^{\circ}$; height.055 inch; least breadth .09 inch; greatest breadth .075 inch.

S'rodstoma Agissizinam. Shell subdiscoidal : horn color, subtransparent: with, on the last whorl, four very prominent sharp carine, viz., one along the periphery, and two below and one above, the latter appearing only for a short distance on the penult whorl; with a fow fine raised spiral lines on the upper part of the whorls and between the carina: spire slightly elevated: whorls three and one-balf, planulate, with a moderately impressed suture; last whorl planulate beneath, near the end rapidly deseending and slightly detached from the penult whorl: aperture very slightly campanulate : labrum slightly reflected, rounded, not sealloped : labium —- umbiliens of molerate size, with the spiral lamella excessively developed and soldered by its exterior edge to the last whorl, forming over the umbilicus a large arch, which has an opening much larger than the aperture of the shell. In the only specimen now before me, there is, around the lip within, a deposit which contracts the aperture, and rising over the labi- 
$10 m$ in a rather thin curved lamella, extends over half the entrance to the umbilical arch.

Mean divergence 16.5); height .Of.5 inch; least breadth .095 inch; greatest breadth .118 inch.

A small thick variety of Trorhatella pulchelle occurs in Portland, with the spiral ridges remarkably prominent. It may be designated by the name of mermexrsta. Another variety oceurs at the mplosite extrenity of the island, at New Inope in Trestromeland, which is very larege, and has the last whorl well rombled wer the periphery, withont any lieel: it has no seulpture execpt the impressed spiral lines on the spire and on the upper part of the last whorl. The lip is less expanded than in the type of the species. It may be designated by the name of NosiLis.

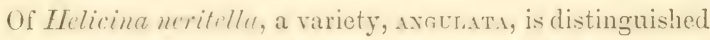
by an angular periphery, and by a double and much thickened lip.

Geommaxa IIndmax. Shell conic-cylindric: white: with, on each whorl, ahout $3: 3$ to $: 3.5$ small obtuse ribs, which are obsolete antericrly and behind the labrum: spire with rectilinear outlines: apex truncate with the loss of __ whorls: whorls remaining six, very eonvex, with a deep suture: aperture suborbicular, moterately elïuse: Iabrum well expanded and reflected, thin; linguiform part noterately produced obliquely on the side, obtuse: labium well thickened and regularly reflected, slightly disjunct from the penult whorl.

ILean divergence abont, $11^{\circ}$; lenerth ...5 inch; greatest breadth .085 inch; least breadth .07 inch.

(rmomiand pramuta. Shell elongate conic: whitish : with, on each whorl, ahont :2- small ubtuse ribs, which, on the last whorl, terminate a little below the periphery: spire with rectilinear outlines: apex usually truneate with the loss of two or three whorls: whorls remaining seven or eight, quite 


\section{Deseriptions of New Species and Vurieties of Shells,}

convex, with a deep suture: aperture widely ovate, moderately efluse : Jabrum rather thin, slightly reflected : linguiform part obtuse, moderately produed laterally at the lower part of the right side: labium a little thickened and reflected.

Mean divergence abont $15^{\circ}$; length 32.2 inch; greatest breadth .11 inch; least breadth .09 inch.

Geomelania costulose, Gi. cilis, G. Hilliana, and G'. striose are as yet unique in the eollection of the Hon. Edward Chitty. C ${ }^{\prime}$. conice is mique in the Zoological Mnseum of Amherst College.

Cylindrella Agnesiana, var. prmaxts. We are indebted to Dr. A. Barrett for this remarkably stmall variety, with the following dimensions: length after truncation .67 inch; breadth .2: inch. In the specimens before us the lip is but slightly expanded. It inbubits Flamstead, in the Port Royal Mountains.

Cylindrelia Robertsi. Shell elongate, fusiform, widest a little below the midule: pearl white: with, on each side of the suture, a series of very short transverse prominent ribs, which abruptly terminate so as to leave a large portion of the middle of the whorls smooth; ribs about fifteen on each whorl; the series below the suture being the larger; both series are continued on the two angles of the produced part. of the last whorl, over on the back part of which each rib is uniterl to its opposite by a small lamella: spire with the outlines quite convex except in the upper third: apex truncate with the loss of - whorls: whorls remaining nine or ten, planulate or slightly coneave, with a deep suture; last, whorl widely disjunet in its last third part from the penult whorl, with an angle on the right and another on the lower side: aperture subangular above and below, more angular on the right: lip mather thin, rellected into the plane of the aperture, moterately expanded.

Lengîh .37\% inch; breadth 095 inch. 
Named in honor of the Honorable Mr. Roberis of Jamaica, to whom we are indebted for this and other interesting species.

Cylindrella rosea, var. ronts. Shell as long as var. major, (p. 21,) but with less diameter and more cylindric.

Cylindrella zonata. Shell cylindric in the lower twothirds, very robust: pink with a tinge of brown or purple, with a pearl white zone along the suture; pale brown in the aperture: with an elegant silky lustre prodneed by crowded oblique very fine stria: spire with the nutlines convex in their upper half: apex truncate with the loss of - whorls: whorls remaining eight, moderately conves, slightly margined on the lower side, with a moderately impressed suture: aperture similar to that of ( $\therefore$ rosece, but more dilated in the lower part of the left side, and with the lip less expranded. It resembles C. cylindrus, but diflers in always having a white zone, and in being often tinged with brown; it is much more robust : the aperture of C. cylindrus is more like that of C. rusea than of this shell.

Length 1.18 inch; breadth .41 inch.

Cylindrellu latu often occurs with a much elongate subconic form. This variety may be designated by the name prodecra. A specimen is 1.2:3 inch long and .34 inch broad.

Under Cylindrella Alungeri may be comprehended many types, which difler in color, form, and seulpiure. These varietics are very local, being strictly limited to their several districts. But many of these clistricts have two varieties. They all conform with great exactness to a common type, which is of much less than generie value. The very considerable numbers of each variety, their strict conformity to their respective subtypes, and their geographical distribution, seem to indicate a specifie value in the diflerenees between them. let the number of types is so great and the differences between many of them are so slight, that we may well hesitate to pronounce No. 9-2. 
them species. It is difficult to avoid the conclusion that the whole group is more comprehensive than a species, while the several local types are of less than specific value, and that it is impracticable to recognise in these shells types of the average value of species.

In attempting to classify such of the varieties as are now before us, we have been surprised at the great constancy of coloring in respect of the kinds and distribution of color. The differences of color in a given variety are almost wholly in their greater or less depth.

The following varieties are in the collection of Mr. Chitty, to whom I am greatly indebted for information respecting them. There are a few more in the collection at Amberst College.

a. Dark colored varieties. In this group, the dark colors fade to a pale brown or cinnamon color.

Var. nigrescens. Shell robust in the lower part, conic above: black on the last whorl and on several of the upper whorls, fading into brown in the middle, with a dingy white stripe anteriorly and a red lip: with a few stria behind the lip. In some localities the shell is of medium size and form, rather more coarsely striate on the last half of the last whorl, and faintly striated on the first half. Inhabits Portland, and Manchioneal in St. Thomas-in-the-East.

Var. solidA. Shell very thick and robust: very dark or blackish brown at both extremities, pale brown alnng the middle, with a pure white widening stripe next below the suture of the last whorl ; pink in the lip and behind it : very coarsely striated on the last whorl, otherwise fecbly striated. In paler specimens a faint tinge of red is scen on both extremities, and the lip is white. Inhabits the vicinity of Peace $R$. in the east part of Manchester.

Var. LEvis. Shell robust but rather thin : livid black in the upper whorls, pale livid brown along the middle, anteriorly 
with a rapidly widening pure white stripe, which unites behind the lip with a broad transverse white stripe that runs through a large triangular black spot; lip white: without strix. Some pale specimens have a tinge of red along the middle. Inhabits Kilmarnock, in the east part of Westmoreland. In another part of Westmoreland is a subvariety, in which the form is less robust, the anterior white stripe is larger and tinged with yellow, and the transverse white stripe, being interrupted by the black spot, appears more like a short spiral stripe: the lip is rather less reflected, and the aperture smaller and more oblique.

Tar. TRIColon. Shell rather robust: very dark brown at both extremities, with a narrow slowly widening snow white line next below the suture; lip rose red, a little whitish where it joins the penult whorl: with excessively minute striae behind the lip. This appears to be Dr. Pfeiffer's var. a. A subvariety is more slender, paler at the end, and darker in the middle, with the aperture less wide. Inhabits Manchester. T'aler specimens oceur near Peace $R$, with the middle whorls of a dingy pearl color.

b. Lighll colored fasciate rarieties, not distinctly striated above the midule whorls. In this group pale yollow fades into a dingy or pearl white, or is replaced by pearl white in fresh shells.

Tar, chassı. Shell rather small, but robust and thick: dark livid brown at both extremities or bluish grey anteriorly ; with a thick white lip; with a narrow white stripe next below the suture of the last whorl, and a slender white line on the anterior keel; otherwise pearl white: with very strong striat on the back of the last whorl, which diminish in ascending the spire, becoming microscojic on the middle whorls. Inlıabits Portland.

Tar. cxuncts. Shell of medium size and form: dingy pale yellow, whiter and sometimes reddish on the last whorl, 
with a broad dark brown stripe anteriorly; white on the lip, with a tinge of rose red behind: finely striate near the end of the last whorl. Inhabits MIanchester.

Var. micixeт.. Shell either short and robust, or of medium size and form: pale yellow in the npper whorls and in the lip and behind it; on the back of the last whorl pure white with two brownish black stripes; otherwise pearl white: with fine strix on the last half of the last whorl. This shell appears to be similar to Dr. Pfeiffer's var. \%. Inhabits Westmoreland.

Var. concinva. Shell small but robust: on the back of the last whorl pure white, with a short black brown stripe; lip white; otherwise pearl white, more or less tinged with pale yellow, especially on the middle whorls: slightly striated on the back of the last whorl. Inhabits Whitney River estate in the east part of Manchester.

Var. sinuata. Shell not robust and rather thin, with the lip remarkably sinnate: of a dingy pearl white, with, on the last whorl, a fine white line helow the suture, and another on the anterior keel; lip pale red, with a tinge of brown behind: with excessively fine striæ on the back of the last whorl. Inhabits the east part of Portland.

c. Light colored varieties, not fasciate, and not distinctly striated above the middle whorls. Changes of color the same as in the preceding group.

Var. RUfiLABris. Shell more or less robust, but rather thin : pearl white, with a tinge of yellow; lip vermilion, sometimes whitish on the inner side: funely striated on the back of the last whorl. Inhabits Portland.

Var. citrina. Shell more or less robust: sulphur yellow; sometimes pearl white when the lip is pure white; with a pure white, well defined, narrow stripe next below the suture; tinged with red at the end of the last whorl: with excessively fine striæ behind the lip only. Inhabits Mranchester.

Var. fusiformis, Ad. vide Proc. Bost. Soc. Nat Hist., Jan. 
1, 1845, p. 14. It is of a pearl or aslyy white color. It is Dr. Pfeiffer's variety $\beta$.

Var. AlBida. Shell like var. citrina, but with the white stripe reduced to an ill-defined line, slightly tinged with yellow on the penult whorl, with the red tinge very faint.

Var. VAlida. Shell robust and very thick: pearl white, with a tinge of yellow on the midale or on all the whorls of the spire; last whorl whiter, with a pure white stripe on it next below the suture; lip pure white and rery thick: strongly striated on the back of the last whorl, finely striated up to the middle of the shell. Inhabits near Peace R., ILanchester.

Var. cxiconon. shell of medium size and form : pale ycllow or pearl white, with a white lip: strongly striated on the back of the last whorl, finely striated on the mildle whorls. Inhabits Porus in the east part of Manchester.

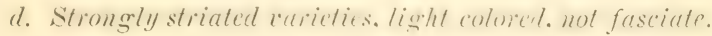

Tar. striatcis. Shell thick, short, robust: pale greenish yellow, sometimes with a tinge of pale brown or horn color: lip white, thick, and well expanted: with fine regular approximate striæ, which are obsolete only at the summit.

Var. striata. Shell short, robust: pearl white or pale horn color; with a white, much expanded, but rather thin lip: aperture not oblique: with fine regular, rather distinet striar, which are obsolete only at the smunit. Inhabits Waterlon in the back part of Manchester.

Var. conplems. Shell large and robust, hut moderately thickened : pearl white, sometines with a tinge of red on the upper whorls and anteriorly: lip white: with a large irregular black spot behind the lip : coarsely striated near the end of the last whorl; otherwise with the striar of the lower haif of the shell most lightly impressed. Inhabits st. Vilizabeth.

Var. Fusca. Shell short, robust, but moderately thickened : pale umber culor, darker near the end of the last whorl; lip white: lightly striated on the upper whorls; in the rest 
166 Descriptions of Now Species and Tarieties of Shells,

regularly and rather coarsely striated. In!ıabits Maroon Town in Hanover.

Var. conics. Shell widest in the penult whorl: white, with a tinge of red at both ends.

\section{e. Tesselated varieties.}

Var. tesselata. Shell rather robust: covered with alternate rectangular spots of cream color and amber, which terminate anteriorly at the cream colored leel; black behind the lip, which is white: smooth above, lightly striated on the lower whorls, and coarsely striated on the black part of the last whorl. Inhabits St. Elizabeth.

Tar. cinerea. Shell of medium size and form: pale ash color; black at the summit: with transverse broad unber stripes, which are numerous and deeply colored on the upper whorls, distant and pale on the niddle whorls, and obsolete on the last whorl; with a dark brown line along the suture and another on the anterior keel; lip white, with a black stripe behind on the right, and a black spot belind on the left : back of the last whorl distinctly striated, otherwise very lightly striated. Inlabits near Acempong town, in the borders of St. Elizabeth, St. James, and Trelawney.

f. Aberrant slender forms.

Var. gracilis. Shell quite slender: pearl white, with a pure white keel and lip : at the end of the last whorl coarsely striated; otherwise with excessively minute striæ.

Var. integra. Shell quite slender: dull white, with a clear white lip: strix very oblique, quite distinct on the last whorl, very minute on the spire. The only specimen before me is not truncated. Inhabits Maroon 'lown in Hanover.

We have been assured by Robert Swift, Esq., and by Rev. E. Hartrig, of St. Thomas, (W. Ind.,) that Cylindrella Maugeri does not occur in that island.

The following forms of Cylindrella belong to the group, of 
which C'. Dunleri is the type. 'The diflerences, although very constant, are sunall, execpt in size. In this respect the differenees are both greater and less constant. Since however the peculiarities extend to many characters, as size, general form, form of the whorls and of the aperture, the sculpture, and color, we regard them provisionally as species, although it must be acknowledged that the varieties of C. Mangeri have nearly as crood a claim to this rank. The same general remarks on their distribution might be made, as in the case of C. Maugeri.

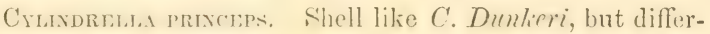
ing in the following characters: it is much larger; is of a redish brown or horn color ; the strie are much finer, being nearly microscopic; the whorls are flat: aperture elliptical and angulated at the lower extremity; lip quite thick: it loses about cight whoris hy truncation and has twelve remain. ing. Inhabits swift R. head, St. George. Length .9S inch; breadth .15 inch.

Cylindrella elation. This is also a larger shell than $C$. Dunlieri, thicker, and strongly striated, with the whorls more planulate: it is much longer and more slender than C.rubra. Inhabits Westmoreland. Length .9:3 inch; breadth .13 inch.

Achatina striose is possibly only a variety of Bulimus octonoides with the columella truncated.

Acinativa proxima. Shell conic but slender: very pale brown or horn color; with dark brown transverse stripes, about three on each whorl, less distinct on the upper whorls: with fine regular transverse small elevated lamellar : apex moderately obtuse, smooth on the nuclear whorls: spire long, with the outlines nearly rectilinear: whorls eight, planulate, abruptly shouldered above, with a rather deep suture: aperture small, ovate: labrum thin and sharp: columella nearly straight. 'This shell resembles A. Blandiana. Its divergenco 


\section{Deseriptions of Nen" Species and Tarieties of Shells,}

in the npper whorls is less than in that slell, but its mean divergence is greater.

Mean divergence about $18^{\circ}:$ length .385 inch; breadth .095 inch; leneth of aperture .11 inch. Inhabits near Swift Fiver head, Portland.

Acinativa somitaria. Shell elongate, ovate conic: pale brown; with dark hrown transwerse lines, about three on each whorl, wanting on the first two or three whorls: with excessively minute crowded transverse stria: spire with the outlines a little convex: apex rather small: whorls eight, moderately convex, slightly shouldered, with a rather deep suture; last whorl subplanulate, long: labrum thin, sharp, a little produced in the mildle: colmmella well produced and turning a little to the left.

Itean divergence about $20^{\circ}$; length .52 inch; breadth .15 inch; length of aperture .18 .5 inch. Inhabits New Hope, Westmoreland.

Spiraxis brevis. Shell long-ovate : pale horn color, translucent: shining, smooth anteriorly, otherwise with rather numerous micruscopic strix: spire with the outlines moderately curvilinear : apex rather small: whorls six, moderately convex, with a well impressed suture: aperture ovate: labrum thin and sharp: columella with the edge moderately projected into the aperture.

Mean divergener aho!t $20^{\circ}$; length .19 inch; breadth .07 inch; length of aperture .08 inch.

The varioty of Spiraris aberans, which was described on page ss as destitute of the transverse brown stripes, may be designated by the name unicolor.

bulimus mirabilis and $B$. anomalus may be referred to the genus Spiraxis.

Bulines hortexsis. Shell much elongate, conic: horn 
color, (or black in the upper whorls, and lemon yellow in the lower whork, when containing the animal alive): with numerous microscopic striir: spire with the outlines nearly rectilinear: apex small : whorls eight or nine, molerately convex, with a well impressed suture: aperture very thin and sharp: columella straight. The whorls are proportionally shorter, and the aperture is wider than in B. subula, I'fr., the revolution of the whorls being much less obligue. It nearly resembles B. octonoides.

ITean divergence abont $18^{\circ}$; length .42 inch: breadth .12 inch; length of aperture .12 inch. Inhahits garleus in hingston.

Benues macrospra. Shell much elongated, conic: palo horn color: or brownish, with a few seattering stripes of dark brown: shining, with excessively minute distant striæ: spire with the outlines a little concave above, otherwise slightly curvilinear : apex obtusi, rather small : whorls twelve, a little convex, with a well impressed suture; last whorl short: aperture ovate, rather wide: labrum thin and sharp: columella nearly straight.

Aean diverence abent $1 \mathrm{~S}^{\circ}$ : length .8 inch; breadth .2 .2 inch: length of aperture 2 inch. Inhabits Maroon 'Iown, in St. James.

Mrli, Chillyona, var. monton, is distinguished by a white lip, and by having the whole lower surface, except the whitish zone at the periphery, of a blackish brown.

A series of specimens connests $H$. carn with $H$. amabilis so clusely. that the latter cannot be entitled to rank as more than a variety. Simne which have the eolor of Il. cara, and a well clevatenl spire, but otherwise resemble II. anabilis, may be called var. MEDIA.

Hndx swarsusina. Shell depressed, conic, subplanulate beneath; with a moderately sharpened periphery, nn both No. $9-3$. 


\section{0}

sides of which the outline is convex: dingy or brownish white; with an ill defined infrasutural line of tiark brown, commencing a little below the apex, and a spiral stripe of the same color below the middle of the whorls, commencing at the niddle of the spire, and another stripe on the last whorl below the peri hery; with the lip white: indistinctly granulated; with fine irregular strie of growth: spire convex, moderately elevated: whorls nearly five, concave in the lower part, in the rest convex, with the suture lightly impressed: aperture transversely ovate or elliptical, with the lip well reflected backwards, and much thickened, with three tecth on the lower side, of which the outer pair are joined together at base, and all of which have corresponding external furrows: unbilicus deep, partly covered by the expanded and thickened columella. Inlsabits Westmoreland.

Greatest breadth 1.13 inch; least breadth .98 inch; height .6 inch; diameter of umbilicus .2 inch.

IIeli, ingens, var. mprirror.st, without an apparent nmbilicus, is more common than the umbilicated type. Another variety, mbmis, is of much less size, and is much less acute at the periphery. It is also imperforate.

Hedix cosistactane. Shell depressed, rather more convex above than below: very dark reldish brown, with a pale brown or dingy white lip; often with a pale stripe on the periphery: finely but strongly granulated on both sides: spire regularly convex: whorls rather more than four and one-half, moderately convex, a little depressed at the lower side next the suture; last whorl with a narrow not very prominent keel on the periphery: aperture transversely ovate, much dilated, and produced laterally; labrum well reflected backwards, and thickened, with four tecth below, of which three have corresponding deep external furrows, labium closely ap)pressed but thick: umbilieus rather narrow, deep, partly covered with the dilated columella. Inhabits Portland. 
Greatest brcadth 1.0 inch; least breadth .91 inch.

I variety, mpsnonsts, is larger, rather less depressed, and without an open umbiliens. It inhabis.s. swift liver head, in St. George. Another variety, carrista, is more sharply and prominently carinated at the periphery. It inhabits the other end of the is:iand, at Jelle lsle, in Westmoreland.

Helix anomala, var. paluescexs, is horn colored, sometines with a reddish brown tinge, withont a white line on the periphery. 'Ihe mubiliens is somewhat narrower, and the shell is higher in the last whorl. It inhabits Acempong 'I'own, in the back part of it. Filizabeth. Another variety, coxvexs, $i_{s}$ remarkably convex on both sides, especially beneath, and has a very narrow umbilicus. It inhabits the borders of Nanchester and St. Elizabeth.

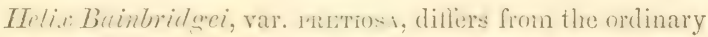
type of the species in heing white, with an exceclingly thin greenish epidemis on the list whorl: the lip is of a very pure snow white color; and the last whorl is larger and higher.

Insmx Buntax. Shell sublobose, obliquely ellipsoidal: white, with a very thin yellowish hown epitemis: with very fine stria of errowh ; some specimens have, on the lass whorl, lightly impressed nicrosenpic spiral lines, and rarely its surface is microscopically punctulated: spire convex: apex very obtuse: whorls nearly four and one-half, convex, with a rather deep suture: last whorl very large and globose: aperture rather large, with a semicirenlar online on the right, and a sinnate outline on the leli: labrum thin and sharp: labium with a dilated closely appressed deposit: umbilicus wanting. Allied to $I I$. Indicule and $I$. mundu. Inbabits Westmoreland.

Greatest breadth .(j.) inch: least breadth .55 inch; height .53 inch. 


\section{Descriptions of New Species and Varieties of Shells,}

Named in honor of my Conchological friend, Dr. B. W. Budd, of New-York City.

Fresh specimens of Ilelix: Blandiana have reddish brown transverse ill defined stripes alternating with pale brown spaces.

Helix pulcmior. Shell subconic, rather thin : of a very light bumt-sienna color, sometimes with a tinge of cream color, on which are more or less numerous ill defined unequal transverse lines of a rich dark burnt-sienna; often with a tinge of asls color on the upper whorls; with a spiral rather dark line of the burnt-sienna a little below the suture, above which the transverse dark lines rarely extend; with another very dark spiral stripe of the same color along the suture and on the periphery of the last whorl; with a well defined large very dark circular spot of the same color on the umbilical region, which is sometimes margined by a pale circle, exterior to which is a line of rather dark burnt-sienna; sometimes with a fine spiral line of the same culor on each side of the periphery: surface moderately shining, with fine close strie of growth: spire with the outlines moderately curvilinear: whorls five, a little convex; last whorl subangular on the periphery : aperture wider than long: lip thin and rather sharp, slightly reflected: umbilicus wanting. This most richly colored of the Jamaica Helices is allied to H. subconica. Inhabits Portland.

Greatest brealth .65 inch; least breadth .57 inch; height .5 inch.

A variety has the dark nmbilical spot margined with a circle of bright eream colur, with another stripe of the same next below the dark periphery. It imhabits st. 'Thomas-in-theEast.

Her.ix Jaconensis. Shell depressed conic, transversely ovate: yellowish horn color: with very fine well impressed crowded strix of growth : spire with the outlines but littlo 
convex : whorls four and nne-half to five, a little ennvex, with a moderately impressed suture; last whorl subangular : aperture transversely ovate, laterally dilated: lip but little reflected and thickened exerpt. in the columellar part, which is well thickened, reflected, and appressed : umbilicus wanting. In form this shell most resembles a very depressed $I I$. fuscocinctu, but is much more dilated laterally near the aperture.

Greatest breadth .94 inch; least brealth .75 inch; heighth .6 inch.

This species is named for its habitat, the parish of St. James.

IIfux spreta. Shell orbicular, moderately depressed : very pale horn color, translucent: smooth : spire with the outlines a little curvilinear : whorls five, quite convex, shouldered, with a rather deep șture; last whorl well rounded : aperture sublunate: labrum thin and sharp: umbilicus rather narrow and deep. This speeies is best described by comparison with II. peraffinis and II. Buothiana. Ahove, the spire is nearly as much depressed as in the former species: beneath, the last whorl is nearly as convex as in the latter, while the umbilicus is as wide as in the former ; the aperture is not so wide as in H. peraffinis nor so high as in $\mathrm{H}$. Boothiana.

(ireatest breadth 2.5 inch; least breadth .2.) inch; height .17 inch.

Tariety rRsaxs differs from the above, in having the whorls less shoulderei and consenuntly the sutme less deep, and in having the region around the umbilieus somewhat thickened internally so as to be opaque.

Heli. epristylium var. mon diflers fom the common type of the species in being much smaller, with a more rounded outline; beneath it is considerably more convex; the surface is less shining. Greatest breadth .5) inch; least brealth .49 inch; height 4.5 inch. It inhabits Westmoreland. At the opposite extremity of the island, in Portland, II. epistylium is 
represented by a variety which is more variable in size, and the small matme specinens are nearly intermediate between var. minor and the common large type, which inhalits Manchester and other midlle parts of the islant. It Fusington in St. Divid's, is another variety, distinguishable from the small specimens, which oceur in the neighboring district of Portland, by the entire absence of any internal Jamina or teeth. It may be called Detanmita.

The same name, DELA IIINATA, may be given to a variety of H. osculans which wants the internal lamina.

Proserpina nitida var. Planulata is distinguished by being much flattened above.

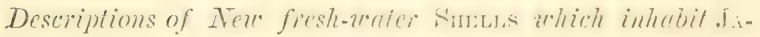
maica. By C. В. Adais. April, 1851.

Pirysa Janatcensis. Shell long ovate, acuminate: brownish horn color: with microscopic strie of growth, and some lightly impressed microscopic spiral stries: apex acute : spire well lengthencel, with the outlines slightly eurrilinear, with a well impressed suture: aperture long ovate : lip thin.

Length of aperture .:2:) inch; total length . 13 inch; brealth .25 inch.

This species was found plentifully in a tank at Malvern, more than 1000 feet high, in the isolated group of the st. Cruz Mountains in St. Elizabeth. Ihe strueture of the country for many miles in erery direction is such that no water is ever seen standing on the surface. I'lhough innunerable subterrancan fissures rain immediately percolates to unseen depths. Artificial tanks are therefore the only places where fresh water 
shells can exist in this recrion. Tre are quite ignorant of the manner in which this species was introduced to its habitat.

Nentwa Junuex:1: Shell obliquely ellipsoidal, rather thin: white near the apex: otherwise covered with violet, which is sometimes linged with dark gray, with lighter and darker shates in spiral bands, aul is moro or less interrupted by lines of erowth and irrerular white spots: surface smooth and shining: apes mother proninent: spire convex: whorls nearly three, with a line but well inpressed sutural line: labium smooth, moderately thickened.

Lengih of spire 0 \% inch; height .3 inch; brealth .3\% inch.

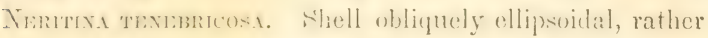
thin: black, with numerons ancular translueent spots of horm color: white on the labinm, blue within the aperture: with numerous exeesively fine spiral and ineremental strie : apex quite prominent : spire convex: whorls two and one-half, with a very fine but well impressed sutural line: labium smooth, moderately thickened. Inhabits Black River.

Length of spire .06 inch; height .36 inch; breadth .41 .

It afliorls ms maneh pleasure to find two new fluviatile species of this genus in the Jamaica Famma. With the exeeption of $\mathrm{X}$. punclululu, all the ofther speecies are strietly marine, living upon the open sca-shore. If authors are correct in stating that St. Dominge is the habitat of N. punetulata, that species is the only fluviatile shell in . Jamaicat, belonging to a genus of well characterized species, which is not peculiar to the island. Possibly Iamarelis statement of habitat is erroneons, arising from the shells laving gene to Erance by way of St. Domingo. 
Remarlis on the Mubitals of certain species of Lavd Sneths. By C. B. Anars, Professor of Zoology in Amherst College, Mussachusells, and Fidwand Chitry, Chairman of Quarter Sessions, Jannica. April, 1851.

In the following catalugue of the shells of Jamaica, some speies care entumerated which we have not yet been able to find in the island. Some described species are cioubtfully identified with our specimens. (Others, which are clearly identical with Jamaica shells, have been referred by authors to other habitats. In the hope of eliciting information from any, who may be more particularly aequainted with the facts, we invite the attention of our readers to such species.

The following species, said to inhabit Jamaica, we have not found. Cyclostoma labeo has been described by many authors as a Jamaica species. It is very unlike any shell that we have seen or heard of in Jamaica. Cyclostoma asperulum, Sowb., may perhaps be identical with some of our shells. Its aflinities confirm the statement of its habitat. As to $C y$ clostoma corngatum, see C. C., page 141.

Trochatelle Greyane Pfr. and Itelicina Gossei Pfr. we have not identified. Helicina picta Fer., said to occur both in Martinique and in Jamaica, we have excluded from the catalogue. Cylindiella ulubustrinu Pfr., a sinistrorsal variety of C. Humbolelliana Pfr., and a unilormly white variety of C. variegalu Pfi., Culian species, are also said to oceur in Jamaica, but we have not yet identified them.

Bulimus rufescens (rray and Mrlix. IIartiniuna Pfr. are also unknown to us. 'The latter is referred to Jamaica on the authority of Attanasio, a dealer who collected some of the shells of Jamaica during a visit to the island. On the same authority $I I$. Oleniana P'fr. is said to oceur at Savannala-mar. Having seen a specimen kindly loaned to us by Mr. Cuming, we think it distinct from any of our shells. It ap- 
pears to be a Jamaica type. Helix angustata Fer. is said to occur both in IIayti and 'in Jamaica. (Mke. in Zeitschr. f. Malak. 1845, p. 61.) We have never seen it in this island.

We are also somewhat doubtful of the identity of Cyclostoma lincinellum Isam. with C. spimulosum $\mathrm{Ad}$., and of $C$. Banksianum Sowb. with C. hyacinthinum Ad.

Several species of Jamaica shells, described by Mr. Sowerby, are said by him, on the anthority of Mr. G. C. Bainbridge, of Liverpool, to inhabit Demerara. 'To the species mentioned by us on pp. 17-9, and p. 10s, (Cont. Conch.) may be added Cyclostoma mirabile Wood, if, as we now suppose, that species is identical with $C$. decussatulum Ad. In the absence of direct information concerning the shells of Mr. Bainbridge, we must be allowed to doubt whether species, which inhabit the rocky mountains of Jamaica, do also inhabit Demerara.

The following species also are known to us to inhabit Jamaica, but are said to occur in other islands: Cylindrella breris Pfr. in Martinique and Cuba; Achatina leucozonias in Martinique; Dominicensis in Hayti; and A. vemusta var. unicolor Pfr. in Demerara. We mention only those examples which are most likely to be erroneously referred to other islands.

We suppose the following species, which have been deseribed by one of us, to be natives of Jamaica, but they are not certainly known to us as such. Cyclostoma Newcombianum was received from Dr. Newcomb as a Jamaica shell. Cyclostoma aurora formed a part of a valuable collection of the shells of Jamaica, which had been made by the late Mrs. W. J. Wilkinson. Cyrlostomn T'appaniamum was presented to us by R. G. Marshall, Esq., of Morant Bay, being the only terrestrial species in a small collection of supposed Jamaica shells, which belonged to the late Mr. Houseman, a musician, in Kingston.

No. $9-4$. 
The following errata occur in No. 8: On p. 137, first line, for "rugodens ;" read "rugose and". On p. 139 erase the 13th line. At the bottom of p. 140, we neglected to mention Cyclostoma asperulum as belonging to the group of shells there mentioned. 


\title{
C A T A L O G U E
}

OF THE

\section{LAND SHELLS WIITCH INHABIT JAMAICA.}

\author{
BY C. B. ADAMS,
}

PROFESSOR OF ZOOLOGX, ETC., IN AMHERST COLLEGE, MASSACHUSETTS.

APRIL,

1851.

\section{FAIMILY CYCLOSTOMID平。}

CYCLOSTOMA.

$\$ 1$.

1. C. anomalum Ad.

\$2.

2. C. pulchrum Wood.

3. C. fimbriatulum Sowb.

a. var, docens Ad.

b. var. albinodatum $\mathrm{Ad}$.

4. C. Chittyi Ad.

5. C. amabile Ad.

6. C. Hillianum Ad. a. var. aculeosum Ad. b. var. leporilabre Ad.

7. C. lincinellum Lam. Syn. (?) C. spinulosum Ad.

8. C. Moussonianum Ad.

9. C. scabriculum Sowb. Syn. C. amandum Ad.

10. C. lincinum Linn.

11. C. lima Ad.

12. C. Blandianum Ad.
13. C. retrorsum Ad.

14. C. pisum Ad.

Syn. C. virgineum Ad.

\section{$\$ 3$.}

15. C. variabile Ad.

a. var. concentricum Ad. .

16. C. intermedium Ad.

17. C. Grayanum Ad. Syn. C. obscurum Gray.

15. C. serriferum Ad.

19. C. granosum Ad. Syn. C. nodulosum Ad. var. aberrans Ad.

20. C. pulchrius Ad.

Syn. C. Binneyanum Pfr.

21. C. mutatum Ad.

Syn. C. articulatum Sowb.

22. C. mirabile Wood.

Syn. (?) C. decussatulum Ad.

23. C. mirandum Ad.

24. C'. moribundum Ad.

25. C. monstrosum Ad. 
$\$ 4$.

26. C. Vilkinsoni Ad.

27. C. modestum Ad.

28. C. Campbellii Ad.

29. C. avena Ad.

30. C. Shepardianum Ad.

31. C. xanthostoma Sowb.

a. var. albilabre Ad.

32. C. tenuistriatum Ad.

33. C. ignilabre Ad.

a. var. albilabre Ad.

\section{$\$ 5$.}

34. C. Newcombianum Ad.

35. C. fascia Gray.

\section{a. var. proximum Ad.}

36. C. Augustæ Ad.
a. varo nitens Ad.
b. var. testudineum Ad.
c. var, rufilabre Ad.

37. C. sagittiferum Ad.

38. C. thysanoraphe Sowb.

39. C. Jayanum Ad.

$$
\text { Syn. C. solidum Ad. non Mke. }
$$

a. var. rufilabre $\mathbf{A d}$.

b. var. nigrilabre Ad.

40. C. Redfieldianum Ad.

41. C. labeo Müll.

42. C. Humphreysianum Pfr. Syn. C. pictum Sowb.

43. C. interruptum Lam: non

\section{Deless.}

Syn. C. ambiguum Chenu. non Lam.

44. C. Chevalieri Ad.
a. var. album Ad.
b. var. virgatum Ad.

\section{$\S 6$.}

45. C. album Lam.
a.
var. fuscum Ad.

46. C. Bronnii Ad.

a. var. fuscolineatum Ad.

47. C. Banksianum Sowb.

\footnotetext{
a. var. hyacinthinum Ad.
}

$\$ 7$.

48. C. Yallahense Ad.

49. C. lamellosum Ad.

50. C. tectilabre Ad.

$\$ 8$.

51. C. pauperatum Ad.

52. C. simulans Ad.

53. C. crenulosum Ad.

5.4. C. columna Wood. Syn. (?) C. 5-fasciatum Ad.

55. C. Sauliæ Sowb.

56. C. sericinum Ad.

57. C. maritimum Ad.

58. C. aurora Ad.

59. C. Tappanianum Ad.

60. C. Adamsi Pfr.

61. C. fecundum Ad.

a. var. distinctum Ad.

62. C. Griffithianum Ad.

63. C. mordax Ad.

64. C. muticum Ad.

65. C. armatum Ad.

66. C. papyraceum Ad.

a. var. abbreviatum Ad.

$\S 9$.

67. C. Duffianum Adà.

68. C. corrugatum Sowb.

69. C. jugosum Ad.

70. C. pallescens Ad.

71. C. subrugosum Sowb.

72. C. Jamaicense Chem.

73. C. seminudum Ad.

74. C. varians Ad.

75. C. crassum Ad.

76. C. perpallidum Ad.

77. C. asperulum Sowb.

78. C. dubiosum Ad.

79. C. suturale Sowb. 
STOASTOMA.

$\$ 1$.

80. S. Agassizianum Ad.

81. S. Philippianum Ad.

$\$ 2$.

S2. S. Gouldianum Ad.

S3. S. Vilkinsonize Ad.

S.. s. Tappanianum Ad.

85. S. Blandianum Ad.

S6. s. Hollandianum Ad.

87. s. Anthonianum Ad.

88. S. Fadyenianum Ad.

89. S. Petitianum Ad.

90. s. Pfeiflerianum Ad.

91. S. Cumingianum Ad.

92. S. Chittyanum Ad.

- 93. S. pisum Ad.

94. S. Lindsleyanum Ad.

95. S. Redfieldianum Ad.

96. S. Moricandianum Ad.

- 97. S. Jayanum Ad.

98. S. Leanum Ad.

\section{LUCIDELLA.}

99. L. aureola Gray.

a. var. granulosa Ad.

\section{TROCHATELLA.}

100. T. Tankervillii Gray.

101. T. pulchella Gray.

a. var. multicarinata Ad. !

b. var. nobilis Ad.

102. T. Grayana Pfr.

103. T. Josephinæ Ad.

a. var. pulchra Ad.

104. T. tenuis Ad.

\section{HELICINA.}

$\$ 1$.

105. H. palliata Ad. a. var. labiosa Ad.

106. H. Brownii Gray.

107. H. consanguinea Ad.

a. var. soror Ad.

108. H. hirsuta Ad.

109. H. microstoma Ad.

110. H. Hollandi Ad.

111. H. pusilla Ad.

112. H. macilenta Ad.

$\$ 2$.

113. H. maxima Sowb.

a. var. citrina Ad.

114. H. nobilis Ad.

115. H. albolabris Ad.

116. $\mathrm{H}$. citrinolabris Ad.

117. H. dubiosa Ad.

a. var. intermedia Ad.

118. H. solitaria Ad.

Syn. II. Guildingiana Pfr.

119. H. affinis Ad.

120. H. megastoma Ad.

121. H. Grossei Pfr.

\$3.

122. H. Adamsiana Pfr.

123. H. depressa Gray. Syn. II. Leana Ad a. var. valida Ad.

124. H. lineata Ad.

$\$ 4$.

125. H. neritella Lam.

a. var. angulata Ad.

126. H. ampliata Ad.

127. H. Jamaicensis Sowb.

128. H. aurantia Gray.

$\$ 5$.

129. H. costata Sowb. 
TRUNCATELLA.

130. T. sealaris Mich.

Syn. T. Cumingii Ad.

Syn. T. costata Pfr.

131. T. modesta Ad.

132. T. Adamsi Pfr.

Syn. T. scalariformis Ad.

133. T. succinea Ad.

\section{GEOMELANIA.}

$\$ 1$.

134. G. Greyana Ad.

$$
\S 2 .
$$

135. G. fortis Ad.

136. G. Jamaicensis Pfr.

137. G. magna Ad.

138. G. procera Ad.

139. G. gracilis Ad.

$$
\text { a. var. parva Ad. }
$$

140. G. typica Ad.

a. var. pygmaa Ad.
141. G. expansa Ad.

142. G. affinis Ad.

143. G. media Ad.

144. G. vicina Ad.

145. G. minor Ad.

146. G. Hilliana Ad.

147. G. exilis Ad.

$\$ 4$.

148. G. pauperata Ad.

149. G. Beardsleana Ad.

150. G. pygmxa Ad.

$\S 5$.

151. G. conica Ad.

152. G. pyramidata Ad.

$\$ 6$.

153. G. costulosa Ad.

154. G. striosa Ad.

155. G. elegans Ad.

\section{FAMILY HELICID年.}

CYLINDRELLA.

\section{$\$ 1$.}

156. C. gracilis Wood.

- 157. C. elongata Chem.

Syn. C. Cumingii Ad.

Syn. C. Chemnitzima (Helix) Fer.

\section{$\$ 2$.}

158. C. Agnesiana Ad. a. var. diminuta Ad.

159. C. alba Ad.

a. var. striatula Ad.

160. C. subula Fer.

[161. C. alabastrina Pfr.

162. C. Humboldtiana, var. $\beta$ Pfr.

163. C. variegata, var. $\%$ Pfr.]
$\$ 3$.

164. C. seminuda Ad.

165. C. Robertsi Ad.

166. C. costulata Ad.

167. C. costulosa Ad.

$\$ 4$.

168. C. Hydeana Ad. Syn. Bulimus Gossei Pfr.

$\$ 5$.

- 169. C. Gossei Pfr.

' 170. C. Maugeri Wood.
a. var. nigrescens Ad.
b. var. solida Ad.
c. var. levis Ad.
d. var. tricolor Ad. 


$\begin{array}{ll}\text { e. } & \text { var. crassa Ad. } \\ \text { f. } & \text { var. unicincta Ad. } \\ \text { g. } & \text { var. bicincta Ad. } \\ \text { h. } & \text { var. concinna Ad. } \\ \text { i. } & \text { var. sinuata Ad. } \\ j . & \text { var. ruflabris Ad. } \\ k . & \text { var. citrina Ad. } \\ \text { l. } & \text { var. fusiformis Ad. } \\ \text { m. } & \text { var. albida Ad. } \\ \text { n. } & \text { var. valida } \Lambda \mathrm{d} . \\ \text { o. } & \text { var. unicolor Ad. } \\ \text { p. } & \text { var. striatula Ad. } \\ \text { q. } & \text { var. striata Ad. } \\ \text { r. } & \text { var. corpulenta Ad. } \\ \text { s. } & \text { var. fusca Ad. } \\ t . & \text { var. conica Ad. } \\ \text { u. } & \text { var. tesselata Ad. } \\ \text { v. } & \text { var. cinerea Ad. } \\ \text { v. } & \text { var. gracilis Ad. } \\ x . & \text { var. integra Ad. } \\ & \end{array}$

171. C. Hollandi Ad. a. var. Auguste Ad. 172. C. procera Ad. 173. C. montana Ad.

- 174. C. rosea Pfr.

$\begin{array}{ll}\text { a. } & \text { var. magna Ad. } \\ \text { b. } & \text { var. major Ad. } \\ \text { c. } & \text { var. fortis Ad. } \\ \text { d. } & \text { var. ambigua Ad. }\end{array}$

175. C. cylindrus Chem.

176. C. rubella Ad.

177. C. zonata Ad.

- 178. C. aspera Ad.

- 179. C. brevis Pfr.

a. var. obesa Ad.
b. var. columna Ad.
c. var. intermedia Ad.

180. C. Gravesii Ad.

181. C. lata Ad.

a. var. producta $\mathrm{Ad}$.

182. C. nobilior Ad.

183. C. carnea Ad.

a. var. cerina Ad.

184. C. sanguinea Pfr.

185. C. pupæformis Ad.

$$
\$ 7 .
$$

[86. C. humilis Ad.
187. C. inomata Ad.

188. C. simplex Ad.

\$ 8.

159. C. pusilla Ad.

190. C. rubra Ad.

191. C. elatior Ad.

192. C. princeps Ad.

193. C. Dunkeri Pfr.

194. C. similis Ad.

195. C. tenella Ad.

196. C. tenera Ad.

\section{ACHATINA.}

197. A. solitaria Ad.

198. A. ligata Ad.

199. A. Jamaicensis Pfr.

200. A. procera Ad.

201. A. Griffithii Ad.

202. A. Philippiana Pfr.

203. A. elegans Ad.

204. A. venusta Ad.

205. A. leucozonias Walch.

206. A. Dominicensis Gm.

207. A. nitida Ad.

208. A. angiostoma Ad.

209. A. Ingallsiana Ad.

210. A. unicolor Ad.

211. A. Gayana Ad.

212. A. nemorensis Ad.

213. A. similis Ad.

214. A. Phillipsii Ad.

215. A. arcuata Pfr.

216. A. puella Ad.

217. A. tenera Ad.

218. A. longispira Ad.

219. A. proxima Ad.

220. A. Blandiana Ad.

221. A. propinqua Ad. 
222. A. osculans Ad.

223. A. perplexa Ad. 224. A. Gossei Pfr.

225. A. costulata Ad.

226. A. gracilior Ad.

227. A. costulosa Ad.

22S. A. curvilabris Pfr.

229. A. vicina Ad.

- 230. A. pellucens Ad.

231. A. levis Ad.

232. A. micans Ad.

233. A. iota Ad.

- 234. A. octona Chem.

- 235. A. striosa Ad.

\section{SPIRAXIS.}

236. S. costulosa Ad.

237. S. inusitata (Achatina) Ad.

238. S. mirabilis (Bulimus) Ad.

239. S. anomala (Achatina) Ad.

240. S. brevis Ad.

241. S. aberrans (Achatina) Pfr.

a. var. unicolor Ad.

\section{BULIMUS.}

\section{$\$ 1$.}

242. B. minimus Ad.

243. B. striatellus Ad.

244. B. terebella Ad.

- 245. B. pauperculus Ad.

246. B. hortensis Ad.

- 247. B. octonoides Ad.

- 248. B. pallidus Ad.

249. B. monodon Ad.

250. B. nitidiusculus Ad.

4 251. B. subula Pfr.

Syn. B. procerus? Ad.

252. B. læviusculus Ad.
\&2.

253. B. rufescens Gray.

254. B. erubescens Pfr.

255. B. immaculatus Ad.

256. B. zebra Müll.

Syn. B. undatus Brug.

\$3.

257. B. macrospira Ad.

PUPA.

$$
\$ 1 .
$$

258. P. exilis Ad.

\$2.

259. P. fallax (?) Say.

260. P. lata Ad.

261. P. contracta (?) Say.

262. P. tenuidens Ad.

263. P. hexodon Ad.

264. P. servilis Gould.

265. P. Jamaicensis Ad.

\$3.

266. P. striatella (?) Pfr.

\section{SUCCINEA.}

267. S. angustior Ad.

268. S. Sagra (?) Orb.

269. S. latior Ad.

270. S. contorta Ad.

\section{HELIX.}

$\$ 1$.

271. H. Martiniana Pfr.

272. H. peracutissima Ad.

273. H. soror Fer.

274. H. cara Ad.
a. var. media Ad.
b. var. amabilis Ad. 
275. II. Chittyana Ad.

27i. II. patina Ad.

a. var. nobilis $\Lambda \mathrm{d}$.

27\%. II. fluctuata Ad.

27. H. ingens Ad.

a. var. imperforata $\mathrm{Ad}$.

b. var. indigna $\Lambda \mathrm{d}$.

279. H. acuta Lam.

a. var. acutissima Lam.

2S0. H. fuscolabris Ad.

2N1. II. lucerna Müll.

2S2. II. fortis Ad.

28:3. H. Okeniana Pfr.

251. II. Srwainsoniana Ad.

25.5. H. tridentina Fer.

2S6. H. Bromi Pfr.

257. H. valida $\mathrm{Ad}$.

2ss. II. consanguinea Ad.

a. var. imperforata $\mathrm{Ad}$. b. var. carinata Ad.

25.9. H. picturata Ad.

290. H. invalida Ad.

291. II. sinuata Müll.

a. var propenuda $\mathrm{Ad}$.

b. var. candescens $\mathrm{Ad}$.

292. H. strangulata Ad.

293. II. anomala Pfr.

$$
\begin{aligned}
& \text { a. } \\
& \text { l. var. pallescens } A d \text {. }
\end{aligned}
$$

29) 1. H. Bainbridgei Pfr.

a. vav, pretiosa $\Lambda d$.

:295. H. Spengleriana Pfi.

ई 2.

246. H. Redfieldiana Ad.

$\$ 3$.

297. H. aspera Fer.

$$
\$ 4 .
$$

298. H. Jamaicensis Chem.

Syn. H. pulla Gm.

\section{$\$ 5$.}

299. H. angustata Fer.

$$
\text { No. } 9-5 \text {. }
$$

300. II. Cubensis, var. \& Pfr.

301. II. tunicata Ad.

302. Jf. Buddiana Ad.

303. II. MaclIurrayi Ad.

304. H. munda Ad.

305. If. columellata Ad.

306. II. tenerrima Ad.

307. II. graminicola Ad.

308. II. nemoraloides Ad.

309. II. pulchrior Ad.

310. 11. Gossei Pfr.

311. II. Blandiana Ad.

312. II. subconica Ad.

313. H. fuscocincta $\mathrm{Ad}$.

314. H. virginea Ad.

315. H. Jacobensis Ad.

316. II. fuscula Ad.

$\$ 6$.

317. H. immunda Ad.

318. H. rufula Pfr.

319. H. ptychodes Pfr.

$\$ 7$.

320. H. alvens $\mathrm{Ad}$.

is.

3:1. H. perdepressa Ad.

3:2:. H. brevior Ad.

Syn. H. depressa $\Lambda$ d.

:i:: $\mathrm{H}$. sincera Ad.

3:24. H. diminuta Ad.

:325. H. apex Ad.

326. H. inconspicua Ad.

:2: H. Heraffinis Ad.

:3:s. H. Boothiana Pfr.

Syn. H. pellucida Ad.

3:29. H. spreta Ad.

$$
\text { a. var. errans. }
$$

(3:3). H. turbiniformis Pfr.

syn. 11. subpyramidalis Ad.

:3: H. H. Anthoniana Ad. 
332. H. angustispira Ad.

333. H. brevis Ad.

334. H. Hollandi Ad.

335. H. similis Ad.

336. H. arboreoides Ad. Syn. H. Haldemaniana Pfr.

337. H. ambigua Ad.

338. H. osculans Ad.

a. var, delaminata Ad.

$\$ 9$.

339. H. lamellifera Ad.

340. H. pila Ad.

341. H. Foremaniana Ad.

342. H. Cookiana Gm.

343. H. epistylioides Fer.

344. H. alligans Ad.

345. H. epistylium Müll.

a. var. minor Ad.

b. var. delaminata Ad.
346. H. torrefacta Ad.

347. H. connectens Ad.

348. H. epistyliulum Ad.

$\$ 10$.

349. H. simulans Ad.

350. H. dioscoricola Ad.

\$ 11.

351. H. paludosa Pfr.

PROSERPINA.

352. P. discoidea Ad.

353. P. opalina (Helix) Ad.

354. P. nitida Sowb.

a. var. planulata Ad.

355. P. pulchra Ad.

356. P. bidentata Ad.

357. P. pisum Ad.

\section{FAMILY AURICULID五。}

\section{MELAMPUS.}

358. MI. coniformis Brug.

359. M. flavus Gm.

Syn. Auricula monile Lam.

360. M. pusillus Gm.

Syn. Auricula nitens Lam.
361. MI. coronatus Ad.

362. M. cingulatus Pfr.

PEDIPES.

363. P. quadridens Pfr. 364. $\mathrm{P}$. ovalis Ad. 


\section{CATALOGUE OF TIE FRESII WATER SIELLS}

WHICH INHABIT JAIIAICA.

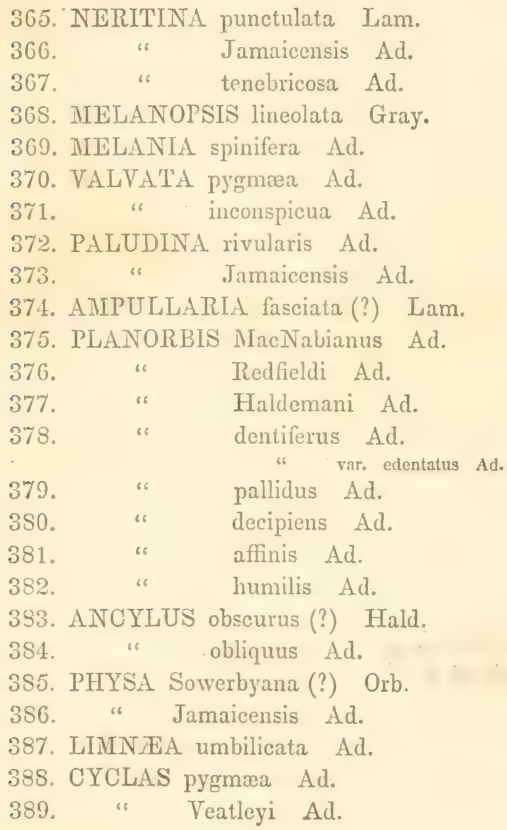

Nutick.-The Hon. Liward Chitty of Jamate laving fumished the writer with his duplicntes of the land and fresh-water shells of Jamaica, so far as necessary for making out suites, a few collections, each containing nearly all the discovered species,-about 500 species and varieties, will be put up for sale, at prices from \$100 to \$150. Suites of single genera, and miscellaneous parcels for selection, (with the privilege of returning such shells as may not be wanted,) can also be furnished. It is proper to add, that the object of the sales is not pecuniary profit, but to meet the expenses of an illustrated mongraphli, the outlay for which probably will much exceed the receipts.

C. B. ADAMS, Amherst, Massachusetts. 



\title{
CONTRIBUTIONS TO CONCHOLOGY.
}

\author{
No. 11 (1).
}

On the Nature amd Origin of the Species of the 'Thrnestrual Mollusca in the Island of Jamaica. By C. B. Adants. November, 1851.

Nоте.-This article, and the one which follows, were read before the American

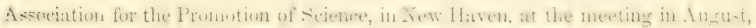
1850 , and were subsequently published in the Proceedings of the Association.

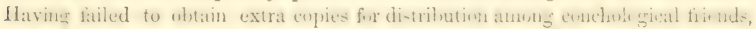
ive reprint them with a few unimportant alterations.

Notwithsianding the diaiculy of exploration in tropical regions, the Island of Jannicat presents rematiable facilities for the invesigation of subjects which are commected with the seographical distribution of species. Ansong the terrotrial shells, typical forms exist ju grent proflision. T'iese toms are of every conceivable grade of value, from varieties up io genera and families. They have also a deferminate goneratphical distribution. The facts on these subjecis are exen more numerous than those which are expanded oxer the wholes temperate recions of North Imeriea. In this resper, therefore, the island is a miniature continent. Probably the sane is true of each of the larger Antilles.

The following rematis will be restriced to certain eonelusions, which are sugeresed hy these latets. The special de. scription of the liacts themselves is reserved for another opportunity.

\section{The Nature of the Species.}

1. Our first conclusion is this ; - that in many groups the species are distinguishable by types* only, and not by well

* A type is the aggregate of distinctive characters. In order to be of specific value it must perpetuate itself in successive generations.

No. $10-1$. 
defined linits. 'This propusition nay be illnsirated by a figure, in which species are represented by cireles, many of which are in contact, and whose areas are suriuklen irregnlarly with dots, which represent varieties. One centwal dot represents the type of the species. Sine larger dots represent types of a value intruetiate between that of species and orlinary varieties. The amonnt of difference between the types may be represented by their distances. On the bnundaries of the species we funt varieties which clesely resuble their neighbors in the adjacent apecies, while their aflinities with the central types of both speejes are so nearly balaneerl, that it is not really a matter of much ennsegnence on which side of them the imaginary boundary line of the species is drawn. On a plane surface, howerer, we have only an approximation to the truth. A nore exaet repreantation of the relations of the types would require the three dimensions of spase. It should be observed also, that the boundaries of the cireles do not represent any facts, which have an objective existence. With the boundary lines, we represent the speces as described in books; without them, we see the species as they. exist in nature.

If all the examples of this kind should be enumerated, very few species would remain isolated. Of such. some might be united by further discoveries; while others might remain isolated, since it is a part of the general plan of organic nature that the spaces between the groups shall be unequal, so that some spereies, some genera, some families, de., shall stand quite alone.

The principle is not peculiar to the terrestrial mollusca of Jamoica. 'I'le Naiadre and the Melanidin of the United States, which have been so thoroughly studied by Mr. Taca, of Philatelphia. are exactly in the same case, but the facts are expanderl ower wider geographical limits. 'l'he same is true of the suails and fresh water shells of Europe, of many groups of marine mullusca, of fishes, of birds, and even of mammals. 
The special investigation of varieties is rapjully filling up the gaps which were one supposed to exist hetwen species. Vot dissimilar is the case of the hmman suecers. which erratuate into each other in such a manner, that the lact is oflen used as an aremoment for combundine all the mares in one sprecies.

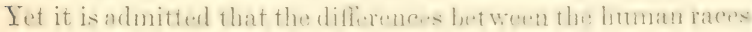
are much greater than hetwen many distingh species wi andmals.

Our conclusion is lirelly experesel in ihe propusition, that species are of the same nature as genera; that is, are to be fonuded on tyjes, whet!er or nor an impassable vacuum can be found between the types.

2 . 'The secomel inforenes on the nature of the speciens and? higher eroups, is this:- that the natural yyles are not susceptible of heing wholly comprehemblel in a fow sneerssires ranks, in each of which all the types shall be wi exactly equa! value; but there is an indefinite series of types within types. which are inequidistant. If in one gerup, as that of Hirlig time. ate and the lindred speceins it is practianble to wablist sev-

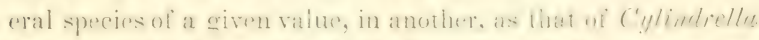

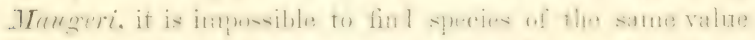

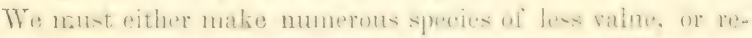
gard the eroup as one species of grmater value. The same doctrine is illnstrated alse by the enmparison of the ereme II lix, in which the number of distiuct stibtyper is very areat,

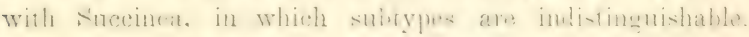
There is no mathematical or plysical reasm why the generie form of suecinea should unt have been regonted with a great diversity of smblypes. Let it is sus slighrly motified in the

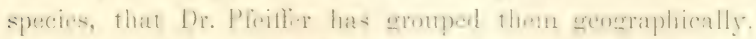
On the contrary, Jletix contains neaty one humdreal typos, of all values intemediate botween a evereric and a sperific value.

In the same manner numerous other genera, familie-, and 
oridrs in all departments of organie nature may be compared, and the same result obtained.

3. Sinee the subtypes of specins are distributed with great resarel to Jocality, it is obvions that much of the perplexity which results form the eraduation of species into each other, is arritind hy these travellers who take hut a few specimens fom dimant huslitirs and by those collertors who are satisfied with a sinele well-characterized specinen of each species. sineh collections are valualite as exhibiting types; but they very imperfoctly represent the relutions of types: as a small gromp of human figures, of which one shonld be an Apollo, another a congo negro, with two or three other as well characterized specimens of distinet races, would very inadequately illustrate the natural history of mankind.

It is oluvieus, also, that a difierence of opinion between any iwo nafuralists on the unestion, whether a given species is a fond species, does not necessarily indicate a want of diserimimalion in the ohervers. It rather indirates that the type in yum-lion is a litile above or heluw the rank into which it is attempted to force it.

What shall we say now of the logical notion of infime spuries. Which womld not only hypothetically characterize a species ly unity of origin, but require us to find an impassable gull between those species which are nost clnsely allied! sueh a ductrite only shows how the world would have been monstructed, if the philosmphers had made it. We will venture to afirm that the facility of disenvering such species will be inversely as the knowledge of the facts.

\section{Origin of the Species.}

Ther common notion of infiner speries settles the question of unity or plurality of origin by definition! But facis conduet to the inference, that the existing species were introduced ly the creation of many individuals, which were modelled 
according to certain types, that were inostly but not wholly local, and which differed from each other unequally, as do the existing varieties.

The proof of this proposition is found in the geographical distribution of the varieties. In the great majority of species, the varieties are so distributed, that the space which is occupied by one of them coincides with that of other two or more. Now, if the circumstances of locality had produced the local types by modifications of one original type of the species, then all the varieties which inhabit a locality should have been affected. In that case, all the varieties in any given place would have the same geographical limits. But the contrary more frequently occurs. Each variety has its own limits of distribution. If a few coineide in the boundary of their province, on the other hand one is often found to have an extent. of distribution, which is equal to that of two or more other varieties. But such a geographical coincidence of one variety with several other varieties is inconsistent with any other theory than that of an original constitutional peculiarity of character in each variety. This inference is confirmed by the occasional intermingling in one locality of varieties, which differ from each other as much as those which occupy distinct regions. If then we assume the original independent creation of all the varieties, each originally represented by at least several individuals, the facts of distribution becnue explicable with the greatest facility.

The same statements might be made respeeting entire species, and eren groups of species and genera. Some are very local, and others, more widely distributed, occupy the ground of several loeal species. We have then indistinet varieties, distinct varieties, doubt ful species, good species, and groups of species, and all the intermediate types, distributed in the same manner. Now, the theory of unity of origin requires us to believe that all the types which are comprised within one 
species are the effects of locality: that the types which are exactly of a specific value were ereated in one contre in a singlestock: (althongh, as we have seen, the notion, that all animals can be reformed to species which are of preciscly the same value, is wholly fanciful); but that those types which are more omprehensive than species had a plural origin of exactly as many stocks as they contain good species! and that species of doubtful value wonld not be doubtful, if we looked at nature throngh the doctrine of the logical infime species !

\section{Notice of a Reversed Cyclostoma.}

In the extensive genus Cyclostoma, only one reversed specimen, so far as we can learn, has hitherto been known to Conchologists. It belongs to the small European species $C$. scalarinam Villa, and is in the collection of Dr. L. Pfeiffer.

Among the inultitude of shells of the Cyclostomidar, which have been accumulating for ages in Jamaica, 1 was unable to find one reversed specimen. Recently, howerer, the Rev. F. $R$. Holland has sent me from Jamaica a reversed specimen of C. Jayanum. The shell has attained nearly its full size, being 0.7 inch. long, but it wants the reflected lip of maturity. This species is one of the most abundant in the island.

From the Proceedings of the American Association for the Promotion of Science. Aug., 1850.

On the Value of the Snilds of MoLusci for the purpose of distinguishing stuecies und lligher Groups. By C. B. Adans, November, 1851.

The following remarks contain litlle or nothing that is new; on the contrary, their object will require allusion to: very familiar facts. For this, I hope that a suficient apology 
nay be found in the, at least, apparent diversily of views whicin exist in reiation to the subjeet that I have announerd.

On the one side Conchologists are said to hase no regard to the inhabitants of the shells which they adnire; on the of her humet a hererogeneous class of writers publisb their own opposite opinion that shells are of no more enserpuence in Tatural listory than the fur of quadrupeds, or even the clothing or houses of men.

TVe cannot areid an expression of dislike to the plirase, "inhabitants of shells," as applied in science to MLollusca. There would be an obvious propriety in it, if applied to hermit crabs (l'agurida, since they have no oreanic connection with the sleclls which they ocenpy. But there is such a conncefion between the soft parts and the sheil of a Mrollusca, that neither alone constitutes an individual being, but the whole together constitutes one animal. It would be no more absurd, in scientific language, to denominate birds the inbabitants of feathers, and mammals the inhabitants of fur or wool, Sc. The term, "the animal," which is frequently used for the soft parts only, is liable to the same objection,- - that these parts alone do not comstitute an animal. Te fully admit, however, the propriety of these terms as figurative language, and would therefore by no means entirely discard them.

A writer in the Zoologriral Jomrnal of London has considcred the question, whether the shell or "the animal" is entitled to the nane of the species, and suegests that two names are necusary! This would be like giving one name to the bones and another to the flesh of a quadruped. But whether we call a skeleton a mammoth. or apply a specific name to a shell, there is mo danger of being misunderstood: we neither infend to grive the shell the monopoly of its name, nor to say that the mammoth never had any " soft parts." In organic nature, individuality resides in the whole being only, and it is the specifuc indiciduality to which the name belongs. 
That Concholngists do not regard the soft parts of the animal, is partly untrue and partly excusable.

In the case of amateur collectors, who value the shells for their beauty or rarity only, it is nbvious that "the animals" have no other means of gaining the attention of this class of persons, except as their shells commend them to notice. The tendency, therefore, of amateur collections, in this, as in other branches of Tatural History, is favorable. Many who begin as amateurs become scientific. If they do not, we yet find them availing themselves more or less of the results of Malacology for the arrangement of their shells, and in various ways encouraging the progress of investigations in which inclination or circumstances do not permit them to engage. We protest, therefore, against the application to such collectors of any terms of disparagement, but would honor those whose hours of recreation, after the futigues of business, are occupied with the enjoyment and study of the beauties of nature.

With the Conchologists properly so called, there is no ground for any imputation. Either by personal examination of the soft parts, or by availing themselves of observations made by others, every possible use is made of the anatomy of the animals, while their habits and geographical distribution are probably as well known as those of any invertebrated animals, unless, perhaps, insects should be excepted. If a Conchologist should in these days elassify shells as univalves, bivalves, and multivalves, and separate the l'estacea from the naked Iollusca, he would indicate a contempt for the animals. If he shonld suppose that the position in which shells were once placed for description, upside down, and sideways, is that in which locomotion is effected, it might be said that he had much to learn. so far, however, is conchology from disregarding the soft parts, that there is in some quarters even a tendency to undervalue the shell.

'I'he study of shells is important on account of the facili- 
fics which they furnish fur learning the extent of the department of Mollusea. of the 15,000 or 20,000 species which have been deseribed, the soft parts of only a small minority have been described, and of a ve $\mathrm{y}$ arge majority the shells enly have been seen by naturalists. I only allude to the value of this subject to Geology, and to the utility of a division of labor in the study of the details of Natural History.

The properition which 1 intend to illustrate is this: that the value of the shells of Mlullusea, as a source of distinctive charanters, commencing at zero for the entire department, inerense as we tirecend thromoh the less comprehensive groups (not of contre in a unilom ratic, but irregularly, ) until ive arrive at the speeics, which may be amply distinguished by the shells only.

That the shells are of no value for the purpose of distingnishing the department of Mollusea, is evident from the multitude of naked MTollusca.

In the first suludivision into classes, they begin to be of sune value. The class Brachiopoda is distinguished by two values, one dursal and one ventral ; the Conchifera always by two lateral valves, and the T'unicata. which otherwise much resemble the Conchilera, are naked. But of the Gasteropoda, some are nakeal and whers are not, and some have shells, which can be distinguished from those of the class of Articulata only when we descend to the characters proper to genera and species. Of the Pteropods also, which some regard as cutitlen to the rank of a class, many are naked, but the rest have peculiar shells. While a large majority of the existing Cephalopula are naked, the shells of the testaceous species (if we include Argonauta) agree only in characters which are common to these of the Gusteropoda, although easily distinguished in the genera. But if, with Mr. Gray, we regard Argonauta as the shell of a Gasteropod, similar to Carinaria, No. 10-2. 
the testacenus species have a well marlied characteristic in being polythalamous.*

It is rery obvions, therefore, that the shells begin to be of sume value in the first subdivision into classes, since of the six classes 1 wo are wholly testaceous, and may be distinguished, not by the shells alone, but by their position on the soft pars: and throe are partly testaceous, of which two may be dintinguislied by their shells so far as they are testaceous.

In the orits. we find their value not much increased. The two mlers of Brachiopodia are distinguished by a single character of the shells, namely, the presence or absence of articulation between the valves. This is not the basis of their ordinal cla-sifuetion, which would be artificial if founded on one characier, but it is an inder: of differences which characterize the entire animals.

'The itro Lamarclian orders of Conchifera are separated ois arranis of a dillerence in their solt parts, namely, the number (whether one or two) of the adductor muscles, which charater is clearly indicated in the shells of all the families except in the Tridaenidie, where the approximation of the two muscles presents the appearance of a single impression. In the Mytilidie, which have several adductor muscles, some of which are inconspicums, the defect in the ordinal character of the soft parts is itself indicated in the shells. In MIr. Gray's list of the Genera of Recent Mollusca; five orders of Conchifera is entmerated. I have not seen them characterized, but it is obvious from their genera that ordinal characters cannot be linnt in the shells. The two orders of Pteropoda in Mr. Ciray: list. as in several other authors, are indicated by the presence wr absence of a shell, although the classification of

* Since this article was read before the Association, we hare seen, with great ful a-ure. 1he complete sulutinu of the problem of the Argonata in the " Voyage of the Samarans." Inhur Adaus, E-q. Surgeon and Naturalist of the Samarang, fiturd that the jaynor Satili are the ugg cares of an Uetopod, carried about by the female. 
Mollusea in that elaborate and excellent paper was designed to include all the modifications that were suresested by an examination of the soft parts of 5,000 species.

The two Lamarckian orlers of Gasteropoda, Gasteropods proper and Trachelipods, each contain both naked and testaceous MIollusca, but, with some important exceptions, the shells in each order may be distingrished. Mr. Fray's fire orders of this elass cannot be distinguished by oidinal characters of the shells.

In the three orders of Cephalaporla, one is inclieated by the shells of Nautilus. The other two orders, including Argonautide, contain each one testacens genus, with many naked genera; but these testaceous genera are widely diflirent.

If we modify Mr. Gray's system by dividing the Brachiopoda into two orders, and by regarding Argonauta as the shell of an Octopod, we have (including the T'unicata) seventeen orders, of which two are naked, ten are wholly testaceous, and five are partly testaceous. But of the fifteen which are more or less testaceous, only five are easily separated by ordinal characters in the shells, and the others are distinguished with more or less difficulty.

In descending to the familis, we fund the value of the shells much greater than in the orders. Here I will limit $m y$ remarks to the families in IIr. Gray's list of genera, buth in avoid unneessary detail, and because they are comstimier with more regard to the soft parts than those of any ofher classification.

In the class ('ephalopola, the two testacens genera ( $\operatorname{Irg}(\mathbf{x})-$ nauta being excluded from the class, ) constitute as many fanilies, which are, therefore, amply indiruted by their shells.

In the first order of Gasteropoda, Pectinibranchiata. Mr. Gray makes five families, of which three, simmbialw. Volntide, and Cypreader, are easily distinguished by their sicls: 
but the family Muricida embraces some species of I'leurotoma and of Conus, whose shells are not easily clistingnished by family characters from some of the Buccinidx. We aro not aware, however, that the soft parts could be distinguished with any greater facility. This is an example of the gradation of types into each other.

The sceond order, Phytophaga, contains twenty-five families, of which one, Atlantidæ, is naked; Tecturida (= Lottia$\mathrm{d} x)$ is not distinguishable by ordinal characters of the shells from Patellide in another order; the Littorinidre, containing Solarium, cannot be distinguished from the Trochile, which contains Phillippia; and Vermetide and Dentalidie si) closely resemble certain Annelides, that it is doubtiul whether any family characters can distinguish them. Thie remaining nineteen families may be distinguished by their shells with greater or less facility; the difficulties, where they exist, arising from gradation of types, not fron a want of correspondence between the shells and the soft parts.

The third order, Pleurobranchiata, contains five fanilies, with a remarkable intermingling of testaccous and of naked genera; yet the shells in each family are characterized with the greatest facility, as may le seen fron the well known types of four of them, Bulla, Aplysia, Umbrella, and Carinaria, with which last Mr. Gray associates Argonanta.

The fourth order, Gymnobranchiata, contains cight families, of which two are testaceous, the Patellide and C'hitonidx, which are amply distinguished by their shells, exeept that the former is too closely allied by its shells to Lottiadre, as above mentioned.

The fifth order, Pulmobranchiata, consisting of the airbreathing fiasteropoda, contains twelvo families, of which ten are testaceuus, and are easily distinguished by the shelis, except that Nanina is removed from the Helicidæ and placed with the Arionidx. 
Although, in the class Conchifera, the shells do not furnish good ordinal characters for the five orders of Mrr. Gray's list, yet all of the forty-two families which are distributed through these orders may be easily distinguished by their shells. Also the six families of the Brachiopoda, and those four of the Pteropoda which are testaceons, are easily distinguished by their shells.

Thus of the 95 testaceous families of Mollusea, 8S, or moro than 921 per cent, are distinguishable by their shells.

For the gentric value of the shells, we may take the results in Mrr. Gray's list, which is remarkable for its multiplicntion of genera; 810 recent genera are recognized. Of these 15.2 are nalieu, and 6.15 are testaceous. Of the latter, tho shelis of two genera are said by Mr. Gray to be indistinguishable from certain annelides; and of seven others it is said to be impossible to characterize them by the shells only. This list, although small, is susceptible of reduction; for MI. Deshayes has pointed out the difference between the shells of Vermetus and of Serpula, and Dr. Gould has discovered generic characters in the shells of Lottia, distinguishing them from Patella. Of 61s testaceous genera, 641, therefore, may be distinguished by their shells. This amounts nearly to 99 per cent.

Although the soft parts of 5,000 species of Mollusea, including both the naked and the testaceous species, are known, we are not aware of the existence of a single testaceous species, which is not distinguishable by the shell with as much facility as by the soft parts. The examples are very few, indeed, if any exist, in which the species are not recognized by their shells with much greater ease than by the soft parts.

Of the 20,000 species of shells which are known, the specific value of many is more or less doubtful. It is barely possible that a linowledge of the soft parts will aid materially in determining such species. But this is not probable, since tho 
difficulties arise from the graduation of the specific types into each other, which graduation is, therefore, likely to pervade the whole animal.

The general proposition which we have thus endeavored to illustrate, is cnly a part of a yet more general fact in organic nature-that in deseending from the more to the less comprehensive groups, the characters which are proper to distinguish the groups are more and inore perfectly and uniformly diffused through the parts of the entire being. We have been informed, on the best authority, that the most kindred species of fishes may be distinguished by their scales only. species of birds may be distinguished 'by their feathers, or by their eggs. If we descend to individuals, nothing but observation is wanting to detect their peculiarities in each part of the entire being.

We have thus far considered the subject practically; that is, we have considered the utility of the shells of Mollusca in existing gystems. A few worls should be added on the principles which are involved.

The principles involved in this subject are three-fold; as they belong to the structural relations of the shell, to its functional relations, and to its embryonic history. On the latter we shall not offer any remarks.

The shells of Mollusea, having their origin in the skin, correspond, strietly, with the plumage of birds, the furs of mammals, and the scales of fishes; in general, to the covering of vertebrated animals. The correspondence is exact so far as it relates to the peculiarities of color. But the details of form are inore perfectly represented by the skins of Vertebrata than by the shells of Mollusea. Tet most of the details of form in the soft parts, which are not moulded in the shells, are indicated by constantly associated characters.

In their functional relations, shells are skeletons. They serve for the attachment of muscles and the support of the soft parts. On this ground, therefore: we may claim for them 
a value similar to that of the slieletons of Tertebrata, but admit the amount of the value to be less, on account of the greater simplicity of shells.

It is, therefore, true that a colle ctio 1 of the shells of Mollusca corresponds to a collection of both the stulled skins and the skeletons of Vertebrata, but is of inferior value, both for the reasons just mentioned and beeause their presenee is not universal in their department.

It is perhaps unnecessary to add that while we believe that the shells of Mollusca are suflicient fir distinguishing species, we would not regard them as alone ilhe basis of species. This would be an artificial method, although in the results it would coincide with the natural method of classification. But the shells are partly the basis of, and partly the index to; specific characters.

The following errate in the catalogue of the land and freshwater shells of Jamaica (pp. 179-187) have been detected :-

No. 31, Cyclostoma Newerombiamem, Ad., may be crased from the catalogue. Since the remark on p. 17\%, it has been proved to belong to the Island of St. Thomas. I am indebted to the kindriess of a friend for an extensive suite of varieties of this species, which he collected in that island. The most common variety is that which has been lnown in many collections as C. Surfliumim. I'his name was derived from the IISS. of Dr. W. Newcomb, now of Honolulu in the sandwich Islands, and was given to the species in honor of Robert Swift, Esq., of St. 'Thomas. A red variety has beendeseribel in the Zeitschrift, fur Malakazoologie, subsequently to our description, by Dr. Pleiffer, as C. Troscheli. 'I'he synonomy therefore will stan? thus:

(Cyclustoma Swiftianum Newcomb MSS., 1845.) - NeweombianumiAd. Cont. Conch. Sept., 154:. - 'I'roscheli Pfr., Zeitschr., June, 1850. 
After To. 235, Toinalellina Cuhensis Pfr., should be in. serted.

After No. 285, Helix Schrocteriana Pfr., should be inserted.

No. 291 a may be elevated to the rank of a species, witli the name Hewry pretrus.1. This name was used by Ferusiac for a species of Achatina, 1 . Teruviana. It is however, in accordance with the usage of many, still admissible for a truc Helix. Another name certainly would have been preferable, had not the present name been used by us already to distinguish the type as a variety.

Fo. 3-4. The name Ancylus obliquus having been anticipated by Mr. Broderip for a Chilian s: ecies, Proc. Zool. Soc. Lond., 1832, p. 202, we propose for this Jamaica species the name of A. Chrtтri, in honor of its discoverer.

Nr. Redfield informs $u$ s that in the September number of Reeve's Conch. Icon., which has not yet been received here, (Anherst), Helix incerta and $H$. lima, regarded by, Mr. Reeve as one species, are said to inhabit Jamaica. It is well known to collectors in this comntry that $H$. lima inhabits Porto Rico, and that $\mathrm{H}$. incerta comes from St. John's, near St. Ihomas. We are confident that neither of them inhabits Jamaica.

In the same number of the Iconica, the habitat of Heli.t angustuta is said, on our authority, to be Jamaica. We have before remarked ( $p .177$, ) on what authority this species was included in the catalogue of Jannica shells, although we have never seen it in Jamaica; and since it is said to oceur both in Hayti and in Jamaica, it is not improbable that it inhabits Hayti only. 


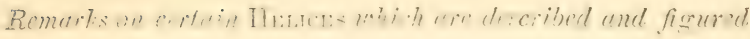
in the Conchologica Iconica for Oct. 1851. By C. B. Adans. November, 1851.

By the politeness of MLr. Redfield we have recoived, in ad. vanew of our own capy, the hat of the Gefober nubber of IIr.

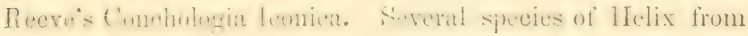
Jamaicat are therein doscribed and ligured, with the aecuracy and elegance for which this work is so justly celebrated.

Helix palina Ad. Mr. Reeve observes that this may prove to be a varialy of 11 . ingens, ant not, as we had sugreested, of H. actia. A full suits of sperineus exhibits its relationship, in opposite dinetions, to beth of thesespecie: When II. patina was describud. 11. ingens was unkuown; and when H. ingens was deseribed, we had but zwo ar three of the most characteristic specimens.

H. acula Lam. The var. aculissima is so unlike the form which Mr. Raeve has weleuted as the type, that those who nay not posess an criensive suite of this i'rotem speeim. would hardly be able to identify it.

H. Chemnilziana Pfr. Syn. H. Auctuata Ad. Dr. Pfeiffer's natne has priority. 'L'he habitat was unknown to Dr. P. when the species was described in the Proc. Zool. Soc. Lond., 1845, and subsequently in the $\mathrm{M}$ Ion. Helic. in 1847.

H. ingens' Ad. Only three or four well colored specimens have been obtained. Such are much more intensely colored than those which Mr. R. has figured.

H. Bainbridgei Pfr. The habitat of this species is said

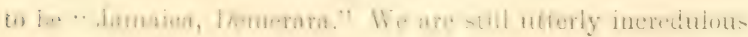

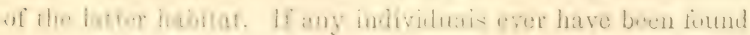

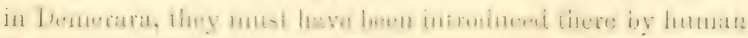
agency.

No. 10-3 
II. lucroma Minll. Mr. Recve's figure of this species repre. sents our H. fuscolabris. The shell which we have regarled as H. Jueerna is much smaller, las the surbee nearly smonth, the aperture less diated, and the lip of the same color within as at the margin. Butween this shell and $H$. aeuta, the shell figured by $M r$. R. is intermediate.

H. tumida l'fr. "Iiabitat, West Indies?" This species, if we may judge without a specimen, appears identical with our H. tunicata. If so, Dr. Pfeiffer's name, published in Proc. Zool. Soc. Lond., 1845, has priority.

H. Chittyana Ad. Elegantly figured.

H. valide Ad. Grood specinens are colored more intensely than Mr. R's figure.

H. anomala Prr. Mr. R. has inadvertently cited us as the original describer of this species. The paragraph cited describes two varieties only.

This nunber of the Iconica contains also the following spe. cies from Jamaica:-H. cara; $H$. peracutissima; $H$. Oteniana; $H$. Spenglerianc; $H$. Jamaicensis : $H$. picturata; $H$. Schroeteriana; H.soror; H.Bronni; H.invalida; $H$. sinuata; $H$. consanguinea. 


\section{CONTRIBUTIONS TO CONCIIOLOGY.}

\section{Tio. 1 .}

Mrxts ox the Geographical Distribetion of Aximals, with siperial Rifience to the Molluser. By C. I3. Addars. October, 1852.

\section{Areas of Species.}

1. Fach species occupies one geographical area only.

2. Species 'introduced' by luman agency from one area into another are obvious exceptions.

3. The literature of Zoology, especially of Conchology; conflicts with the first proposition (\$1) in a great number of examples, chiefly on account of the common practice of publishing statements of habitats, without thorough serutiny into their authenticity.*

4. Inasmuch as natural types are of all grades of value (v. p). 191), so that some are of a little less and others of a little more than the arerage value or importance of a species, the difficulty which hence arises in the discrimination of species must cause some apprarent or doubtful exceptions to our first proposition. The difterenees between some types, which inhahit listinct areas, is slight: and other types exist, between which differenees have not yet been detected, althongh they may actually exist. If such diflerences prove to be absulutely comstant, the types will generally be regarded as good species. But if other-

* We have elsewhere proposen to di-tingui-h oricinal from hearsay testimony, by an exclamation mark. (1)

tof such types 1)r. Gould "almits it as an axiom in Zoolugry," that they "should be asiumet as different, until their ilentity ean be provel."-Introd BFoll. Expl. Exped, p. XI.

No. 11. -1 
wise, the question of their specific ralue may ever remain in doubt.

5. But if we admit the doctrine of species ahove referred to, a few eximnples of identical types in distant areas are not exceptions to the general plan of nature, but an integral part of it. 'The general fact may be thus stated: a mumber of pairs of analogues from two distinct provinees may be so arranged, that the amount of difference between each two shall successively diminish from very distinct species to species less distinet, and then to species scarcely distinguishable, until at length the series shall terminate in two forms quite indistinguishable from each other, that is, in one species. In other words, if the pairs

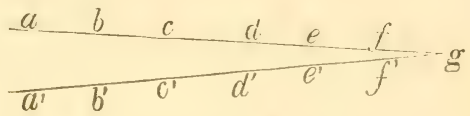

be arranged on both sides of an angle, as in the accompanying ligure, with the amount of difference expressed by the distance across the angle, as from $a$ to $a^{\prime}$, $b$ to $b^{\prime}$, de., the vanishing point of the differences will be in an identical type, as $g$.

6. The areas of species vary from a few miles to screral thousand miles in diameter. There are few which exceed three or four thousand miles. But a great number exceed two thousand miles; and, with the exception of insular terrestrial fauna, a large majority of the areas exceed one thousand miles in diameter.

7. The areas of insular terrestrial species, excepting those which have the power of flight, do not usually exceed the islands which they inhabit, if the islands are thirty to fifty miles distant from each other. As to islands which are separated by one hundred miles or more of water, the examples of species common to two or more are rare. 


\section{Koological Provinces.}

S. 'The geographlical coincidence, more or less exact, of many specific arens constitutes a zoological province.

9. Zoologieal Provinees, excent those which are insular, are for the most part three or four thousand miles in diameter.

10. The fiact that one finma extends through all longitndes in the Aretic regions is not an isolated fact, as has been supposed. It results from the diminution of the degrees of longitude, so that the Aretie zoological province extends through all longitudes, merely because it has the ordinary dimensions of a zoolugieal provinee. (On the other hath, the three great southem points of land, Patagonia, Sonth Africa, and New IIolland, are too remote from cach other to be comprised in one zoological marine provinee." But it may be predieted, that only one zoological provinee will be found in the Antarctic zone.

11. The difference of arquatic, terrestrial, and aerial habits has the most important comnexion with geographical distribution. Next in importance is climate. Next, and of much less importance, is zoological affinity. The influence of zoological aftinity is seen in the fiet that the area of one group of species sometimes does not coincide with that of mother group, of the same habits in respect of elinate and station; as the Melanide and Limniatic of the United States. The sume species of Limniadar extenul through the Western, Middle, and Lastern States, but the Melanidie do not enter any of the Eastern states. Their eastern boundary is therefore four to tive humired miles west of the eastern boundary of the Limniadx.

12. The tigure of a zoolugical provinee depends ehiefly on the distribution of land and water in comnexion with latitude.

13. Several clistinct insular terrestrial zoological provinees

* The separation by water, irrespective of creat distance, wouhl alone grive them distinet terrestrial faune. 
are often comprised within a single marine province. 'Thus the terrestrial faunce of Cuba, St. Domingo, Porto Rico, and Jannatea, are distinct from each other; and the same is true to a great extent of the Viest Indiun Islands generally; those of the Bahamas and Bermulas are atso distinct. But a single marine province extends from the Bermulas to the southern part of Brazil.

14. The attempt to divile up the eartl into one set of zological provinces for all animals, whether aquatic or terrestrial, is therefore futile.

15. The cunverse of proposition 13 , in respect of bodies of vater surrounded by land, does not hold true. In any one lake or river, the proportion of species peculiar to it is small. This ma be said to be uwing to the means of communication in tlue case of rivers emptying into a lake or chain of lakes. But the same extent of distribution is equally common in reslect of unconnected rivers and isolated ponds. It may; therefore, be inferred that the original plan of creation was different from that of the insular species.

16. Because change of climate is always nearly or quite in: one direction ( $\mathrm{Y}$. and S.), and is always more or less gradual, dithences of elimate do nut cause several zoologieal provinces of une surt to be comprise? within zoological provinces of muther sort, but merely render their boundaries indistinct.

17. Because zoological aflinities have some comnexion with aistribution (\$11), incleliniteness of boundaries will result from the attempt to comprise any considerable portion of the animal kinglom in one scheme of zoological prorinees. Absolutely listinct, that is, linear boundaries exist only between single siceies, exeept that the bumularies between terrestrial and Hisular fature are linear, and those between indistinet species are necessarily ill defined.

The canse of indefiniteness of boundaries is to be found in the fiut that the areas of dillirent species do not exactly evincide; although sometimes several nearly coincide, as at 
Cape Cod in Massachusetts, where many marine species meet from either side, but do not pass the boundary.

In general, the boundaries of zombeal provinees which are not insular, are more indefinite, in projortion as we inclucle a greater part of the animal kingrlom in ome set of provinces.

18. Analognes are usually more numerons in adjacent of approximate zoologieal provinees than in those which are remote from each other. Thus there are more analogues in the Caribbean and Panama marine provinces than in the Caribbean and Indian Oceans. The terrestrial fanna of Cubat. St. Dominge, Porto Rieo, and Intmaica, contain many nume analegnes than either of these islands comprared with the Philippine Islands.

\section{Areas of Genera and of more Comprehensive Groups.}

19. The froposition respecting specitic arcas (\$1), may be applied to gromps more comprehensive than species, but with more and more qualification, as the grouls are more and nure. comprehensive, until at length it fails cntirely; and the areas become greater, mil at length the whole planet becomes a single area.

Thus many genera inhahit each a single areat, as cylindir llat. Some genera are chiefly restricted to a single area, ats Chemerilie.* Others are cosmonolite. Some fimilies, a few orders, and at least one class (Reptiles) are restricted each to onc areat. Tropical rewions constitute a simgle area for sereral naturat

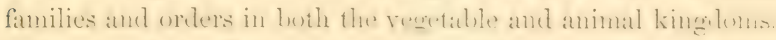
'The area of the Cylratilat consists of the tropical zone with arljacent parts of the temprerate zomes. The areat of the class of Reptiles eomprises all the warm and temperate regions of the earth's surface.

The vanishing print of this fromosition is in the truisu:that the area of the whole amimal kinglon is the whole of the planet.

* See artirele folluwing, on the Clau-ilia of Ameriea, ty Themas Bland, p. 221. 
Retutions of the sutiject to theorits of the migin of speries.

20. It should not be assumed, before it has been proved, that each species has originated in a single central point in its area, nor that physical agents have been the principal cames of the existing phenomena of distribution.*

21. Nitural agents may somewhat enlarge the area of a species, but are not likely to transplant a species into a distinct remote area. Thus if currents or locomotion transport a species into a new habitat, the same species will he likely to oceur at places intermediate between this new habitat and the original area. Consequently the effect of physical causes must usually be limited to the enlargement of specific areas.

22. The small areas of insular terrestrial species and large areas of continental species suggest the theory of centres of creation; for it may be said that the insular species would have spread over equally large areas, if they had not been restrained by water. But although such a theory accounts for these facts, the theory is not proved, because the facts are as satisfactorily accounted for by another theory, viz. that the original plan of creation was different in the two cases.

23. The fact, that the number of species in an insular province is generally much greater, proportionally to the area of the provinces, than in a continental province, proves that the original plan of ereation was different. Thus Jamaica contains mure known species of terrestrial Mollusca than the whole of North America, from the Isthmus to Melville Island. It is mieed probable that there are more unknown species in Nexico and in Central America than in Jamaica ; but it is not frobible that enough remain uncliseovered materially to aftect

* Some writers account for the facts of distribution, and for the introduction of nerieties of species by physieal agents, while they designate sueh a method of accounting for species and genera as atheistical. But it should ever be rememincerl that physieal agents are only the agents of the Divine will ; consequently such opinions are not atheistical. 
the proportion. The species of Cuhal, St. Domingo, and Porto Rico are but partially known; yet they confirm the general proposition. 'The same is true of the land shells of the Philip. pine Islands, and of the Sandwich Islands.

24. The distribution of fresh water continental species also proves that the original creation of the insular species was on a difterent plan from that of the continental species ( $\$ 15)$.

25. If large groups of such islands, as the TVest Indies, should be united in a common area of dry land, then, aceording to the theory which aceounts for the facts of distribution by actual dispersion from centres, there would be zoologrical provinces containing five to tenfuld as many species as any which now exist.

26. The geolugical fict, that continents by submergence become islands, and that islands by emergence become continents, does not aflect the foregoing reasoning, because such changes require an anount of time excecting one geological period, during which time there is a change of faunæ.

27. The original creation of many individuals of a species in difierent parts of its area has been the principal camec of the present facts of the distribution of the individuals of the species. Physical agents hare exerted only a modifying agency.

28. In organic nature, principles are not observer thrumout any department, with mathematical uniformity; on the contrary each idea alpears with varisus degrees of developuent from its maximum to its minimum, and often to a vimishing point. Hence it is probable that the introduction of species hats been aecomplished by the ereation of original individuals varying in number from a great multitule to a few. In the sane mamer the actual numbers of the individuals of species now range from ineonceivale profitsion to extreme rarity.

\section{Relations of the subject to geological reasoning.}

29. Such insular finmat, as have been described in $\$ 7$ anul $\$ 13$, prove that the islands which they inhabit, have ben 
geograplically separate since an era anterior to the introduction of the existing species. But this conclusion does not depend on the assumption that the species would have dispersed themselves over several jslands if they had not always been restrained by water; but on the fact that such small zoological provinces exist nowhere on continents. *

30. The oceurrence of a very few identical species on diflerent islands, or on islands and the mainland, does not prove the union of such land since the existence of the species, because such a distribution may have been eaused by the accidents of dispersion, or ( $\$ 27)$ by independent creation.

31. If the time, when any islands were once united, can be provel geologically to have been more remote than the introduction of existing species, any facts relating to the distribution of the existing species camnot prove the union of such islands. This is a truism, but it secms to have been sometimes forgotten.

32. The occurrence of many species common to different islands, in some parts of Polynesia, renders it probable that such islands have constituted one island since the existence of these species.

33. The frequent oceurrence of analogues and the prevalence of generic or subgeneric types in some islands do not prove the former union of these islands, but may indieate their greater proximity at a former period (v. $\$ 18)$.

34. An apparent exception to $\$ 18$ is mentioned by Dr. Gould (Introd. Rep. Moll. Expl. Exped.). The Samoa and Friendly I- Mam are mue intimately related zoologically to the Society islande, in.... to the Feejee Islands, although the latter are much nearer. Hence we may infer the greater magnitude and prosimity to each other at sume former period of the Simoa, Friendly, and Society Islands.

The above hints have been hastily written lown. They may

* The very linited distribution of certain tribes of animals is not an exception to this statement, which has reference to the general fauna of a country. 
require modifieation: eertainly much is to be done in giving the subject precision and elaboration of details.

In perfecting the science of the geographicat distribution of animals, Conchology may, with the greatest fiucility, render important aid, in consequence of the ease with which great numbers of specinens are collected, transported, and preserved.

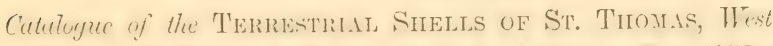
indice. By Thomas Braxi), F. G. S., Loutun. ()., 1852.

The study of the land shells of the Trest Indial Islamels has proved the existence of several distinct terrestrial insular fituna, within the areat of the matrine Caribbean zonlegical frovince.

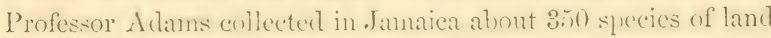
shells, of which three or four per cent. only have been fomel elsewhere. Increased attention is being deroted to the land shells of the other Islands, and we now contribute a list of those which inhabit St. Thomas.

It should be explained that the numbers printes within brackicts, after the numbers of the species, refer to a list in the hands of several gentlemen resident in St. Thomas and elsewhere, who have eollecterl the shells of that jslame, and that specinens, with corresponding numbers, have been deposited in the cabinet of Amherst ('ollege, Mass, L'. S. Specimens of the undetermined species (exeppting only No. 13) have been sent to Mr. In Peiller of Cassol for description. The hope to publish in a sub. serpent mumber of these "Contributions" the names, with references to the descriptions, by Dr. Pfeiffer.

The following shells have been destribed as inhabiting St. Thomas, but we believe erroneously.

Ilelid He putu cirat. St. Tliumas and New Orleans; Cirat. Pfr. Mon. Hel. Viv. No. 28. 
II. plicurie Iam. Tenerifie; Lam. Porto Rieo, St. Thomas, Fér. Pfi. 1. c. No. 761.

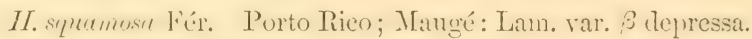
St. Thomas; Grat. Pfr. 1. c. No. 767.

Bulimes luticetus (Ilelir) Fér. St. Thomas: Fér. Canary Is.; Webb and Berth. Pfr. 1. c. No. 200.

B. burlimsus (Mtir) Fér. St. Thomas; Fér. T'enerifte; Webb and Berth. Pfr. 1. c. No. 201.

Pupa decumana (Hetix) Fér. St. Thomas; Beck. Cuba; ()rb.? Pfr. 1. c. No. 49.

Cylineliellue gracilicollis (Hetir) Fér. St. 'Thomas; Mangé: Fér. Pfr. 1. c. No. 22.

C. Menguri (Hetic) Wood. St. Thomas; IIornbeck. Jamaica; Pfr. 1. c. No. 16 . Vid. Ad. Contrib. p. 166. as to the error regarding this shell.

The following shells inhabit the Islant of St. Thromas. (The most important jart of the synonymy of the shells is adted.)

1. (1.) Cyciostoma Antillarum sowh. Thes. ('meh. I. 150.

No. 168. t. 28. f. 180.1843. Megolomastoma Gray Nom. of Moll. de. in

13rit. Mus. Pt. 1. p. 31. 1850. Pfr.Consp. Cyclos. No. 199. 1852.

Sowerby's figure is apparently from a kead shell: when alive it is of a very much darker color. IIe describes it as lhaving 8 whorls. Specimens oceur in St. Thomas with 7,8 , and 9 whorls.

Station.-Among wet decaying leaves under stones.

Itubitut.-Tortola; Sowerby. St. Tineent; (ruilding! Gray. Tortolia and St. Tineent; Pfeiffer. Ifill oplyosite Balier's, near Smith's Bay Estate, East End, St. Thomas; T. B. !

2. (2.) Cyclostoma Newcombianum A.l. Contrib. p. \&. 184!.

Swiftianum

T'roscheli

Nexcombianum
Newcomb MSS. 1845. Pfi. Z.f. Malak. p. 64.1850. Pfr. Consp. Cyclos.

No. 424.

1852. 
Station.-Under stones, and on old walls. After rains, on shrubs, and trunks of trees.

ILabitat-CJamaica; $\Lambda$ d. Contrib. p. 8. corrected on p. 203. St. Thomas; Adams. St. Thomas; T. B.!

3. (4.) Helicina subfusca linke symen. p. th. 1823. rolelline Mich. Pot. et Mich. Gal. I. p. 230.

No. 6. t. 23. f. 11. 12. - 1838.

IIelicina castanea (?) Guild (?) Sowb. Thes. I. p. 13. No.

67. t. 1. f. 31,32 - $\quad 1842$.

- Hornbeckii Phil. Z. f. Malak. p. 125. No.64. 1847.

—— sulfuscu Küster Conch. Cab. Pt. 36. p.

24. No. 23. t. 4. f. 34-36. 1850.

Kiister refers to II. castancal as a varietr, of which Sowerby gives N. America as the habitat.

Slation.-Under stones, and among dead leaves,-rery common.

Habitat.-Porto Rico; Menke. St. Thomas; Potiez and Michand: also Philippi: also Küister. St. Thomnas; 'T. 13..

\section{4. (5.) Helicina}

? Sp. inlet.

Shell molerately depressed, with microscopic spiral stria, brown or vellow, colnuella prodncerl inte a small tooth. 1)iam. .25 inch.

Station.-Under stones.

Habitat.-Blair's Hill, E. of the town, St. Thomas; 'T. B.!

(5a.) Variety of the above, with a white band on the periphery.

Nerlime-Linler stones,-after rain, on the leaves of shrubs.

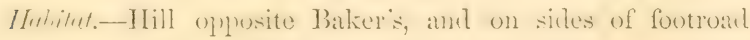
between it and 'l'utu, St. 'Thomas; 'T. B.!

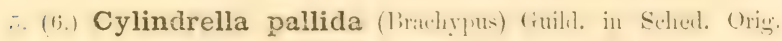
teste P'fr.

$\longrightarrow$ Phil. Abil. II. t. 2. f. 14.

No.31. - - - 1848.

Plidier descrites this as having? to 13 whorls. The matnre shell has 15 to 16 whorls. 
Stution.-Under side of stones-abundant.

Ilubitut.- Trest Indies; Philippi ; also Pfeiffer. St. Thomas and St. John; Mus. Aml. Tpuer part of the hill opposite Baker's, St. Thomas; T'. B.!

\section{6. (10.) Cylindrella — ? Sp. indet.}

This species belongs to the genus Macroecramus of Guilding. In shape and size it is not mnlike Bulimes Kienrivi Pfr. (Mon. IIel. Tiv. II. No. 202. Pr. Conch. Icon. sp. $46: 3$,) from Honduras, but the sutures are not crenulated, and the last whorl has at single sharp keel at the base, somewhat similar to $B$. ninirarinatus (Pupa) Lam. (Eil. Desh. TIII. 1). 173. . To. 10. Pfr. 1. c. No. 205. Rr. l. c. sp. 468,) from Cuba. A Purto Rico species is very like the St. Thomats shell, but is larger, and has the keel less deve-

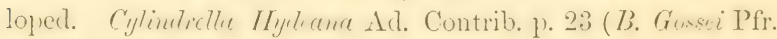
1. c. No. 206 . Rr. 1. c. sp. $4(; 2)$, from Jamaica, is of the same general character, but is much smaller, and has no keel. D. turriculu P’fr. (1. c. No. 207. Rr. 1. c. sp). 497 ,) from Cuba, and ('ylincliclle puntijire Gould (in Bin. T'err. M[oll. of U. S. II. 1).306,) from East Florida, and also from Cuba, belong to the same group.

Station.-Under stones, and on rocks.

Mubitut.-Summit of the Hill opposite Batler's, St. Thomas; T. B. !

`. (†.) Achatina octona ('hemm. IX. I’.2. l' 190. t. 136t. f.

1264 - - - - 1786.

Bulimus octonus Lam. ed. Desh.VIII.p. 233. No. 27.1838. Achatina octona Pfr. Monog. Hel. Viv. II. p. 266.

No.65. - - - - 1848.

- Rv. Conch. Icon. sp. 84. - 1849.

strutiun-Cuder stones, and among deal leaves: very common.

Itulutut.-IV. Indies; Chemnitz; IV. Indies, S. Anerien, Pacific Is. ; Reeve. St. Thomas; T. B. ! 


\section{8. (22.) Achatina - ? Sp, indet.}

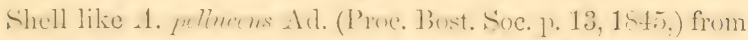
Jamaica, lunt the enlumella is much curved. Length .27 inch.

Station.-Unknown-a few dead specimens only were collected.

Habitat.-Hill opposite Baker's, St. Thomas: T. B.!

9. (15.) Achatina iota ? A.1. I'roce. Thest. Soce p. 1:3. -

1845.

Pfr. Mon. Hel. Viv. II.p. 295. No.150. 1848.

It is not easy to distingnish this from the shell originally deseribed hy l'rof. Arlans as . 1. inta, from Jamaica, although it is much laterer tham the shells which have been emmonly distributed under that name.

sutim.-Lnknown-dearl specimens only were collected. Habitat.-Catharineberg, St. Thomas; 'T. B.!

10. (8.) Bulimus exilis
(II lix) (imel. 1. 3668 . X. 252.

1788.

- Guadaloupensis Brug. Enc. Meth. I. p. 313.

N. 26. - - 1789-179:. Lam. Ed. Desh. VIII. No. 22. 1838. Pfr. Mon. Hel. Viv. II. p. 223. No.612. 1848. Riv. Conch. Icon. sp. 292. 1848. Guadaloupunsis Rr. Conch. Icon. sp. 294. 1848.

Reere deseribes and figmes 7 , witis Gmel. as a species dis-

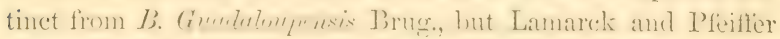
describe them as one species. Reeve particularizes as to the former, that the sutures are inclinel to be white, and as to the latter, that it may be distinguisher he the feculiar rumetrate form of the aperture. An examination of a considerable munber of specimens colleeted in st. Thomas. shows that the characters pointed out by Reeve are not so enstant as to warrant the division into two species. Reeve's I), rulrifiemintus (Conch. Icon. sp. 27t) may be nothing more than a variety of l3. exilis (inel.

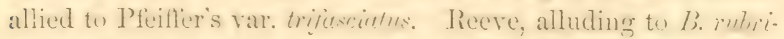
fueriutus, says, that Deshayes, he believes, has "proposed the 
mane B. exilis for this species, already occupied by Gmelin." 1)eshayes in his eclition of Lamarck (V III. 1). 232) adds a note to the description of 13 . Guentulong nes Brug., in which he merely asserts that Gmelin's name, collis, has priority over that of Bruguière.

Var. $\beta$ trifasciatus I'fr. Mrn. Mr.l. Viv. II. p. 22!. No. 612.

Station.-Under stones, amongst grass, and on stems of shrubs: very common.

IIubitat.-Unknown; Gmelin. Guadeloupe; Bruguière : also Limarck: also Pfeiffer. West Indies; Reere. (Unknown; (B. exilis) Reere.) Guadeloure, Martinique, St. Bartholomew; St. Thomas; Mrus. Aml. The grareyard WV. of the town, St. Thomas; '1. B.!

11. (11.) Bulimus virgulatus (Cochlogena) Fer. Prod. p. $396 . \quad$ - $\quad$ - 1821.

Fer. et Desh. Hist. II. 2d part. p. 91. t. 142. B. f. 1-7. - - 1820-1851.

Caribccorum Lam. ed. Desh. VIII. No. 26. 1838. virgulatus Pfr. Mon. Hel. Viv. II. p. 202. No.551. - $\quad 1848$. Rr. Conch. Icon. sp. 320. 1848.

Sereral pretty rarieties oceur; the most common are, exterior wholly white, pale brown within, often with the columella. hlackish brown; or white with chesunt colored transverse lines. The spirally banded varieties are scarce, and that of a "rich reddish saffron" color ( $\mathrm{Rv}$. Conch. Icon. fig. 320 a) does not inhabit St. Thomas.

Station.-On the trunks of trees.

Ilulvitul.-Brazil? Antilles, Porto Rico, St. Bartholomew, St. Domingo; Férussac in Prod. Antilles; Férussac and Deshayes in IIist.: also Lamarck: also Pfeifler. West Indies; Reeve. Martinique, St. Bartholomew, Tortola, St. Thomas, Porto Rico. Curaçoa? and Bonaire: Mus. Amh. Hills about Baker's, St. Thomas; T. B.! 
12. (9 and Oa.) Bulimus Dysoni? I'fr. in Proe.Zoul. Soc. p.

39 . - - 1846.

Pfr. Mon. Hel. Viv. II. p.

183. No. $493 . \quad-\quad 1848$.

Rv. Conch. Icon. sp. 425. 1849.

Stutim.-Tnder stones, and amonger dead leaves,-(o) immon.

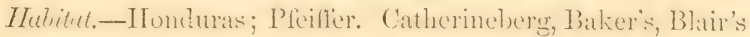
Hill, \&c., St. Thomas; 'T. B.!

The occurence of this spreics, and of Cylindielle fieneri (Bulimns) Pfr. in st. Thomas, sugesests the inguiry whether they may not have been aceidentally mixed with Mr. I)yson's Honduras shells.

\section{3. (9b.) Bulimus — ? Sp. indet.}

This specie's resculles B. Hysoni Pfr., but is shorter, ancl more ovate, with the aperture narrower anteriorly.

Stution.-Linknown; a very few dearl specinens only were collected.

Habitat.-Catharineberg, St. Thomas; T. B.!

14. (1․) Bulimus subula! (.chatina) Ifr. in Weigm. Arch. Pt. I. p. 352. No. 24 - 1839. Pfr. Mon. IIel. Viv. II. p. 15s. No.

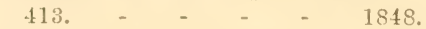

Rv. Conch. Icon. sp. 494. $\quad 1849$. hortensis? Ad. Contrib. p. 169.

1851 .

The 7) menems Ad (Proe. 13ost. Sue. 1) 13, 1345,) from Jamatea, which is consilered hy l'feitrie and Reere as inlentical with ls. sulmlu Pfr. is, aceording to Poey (MS.'), quite distinet from that species, while the true $B$. sulumle from ('uba alpears to be islentical with the 73. horlensis of Jamaica, and with this species from St. Thomas.

Vurlim.-Luder stmues, and anongst dry carth; common.

Mabitat.-Cuba; Pfeifter: also Poey! in Mus. Amh. Jamaical Arlums! also Pfeilier. 'The graveyard west of the town, St. Thomas; 'I. B.!

15. (13.) Bulimus — ? Sp. indet. 
This resembles B. terebella Ad. Contrib) p. 2S, 1819, but is less slender, and has the whorls somewhat flattened.

S'rutim.-L'niler stones, and among deat leaves, and dry earth; common.

Halitat.-Catharineberg, Misgen \&c., St. Thomas; 'T. B.!

16. (14.) Bulimus ? Sp. indet.

This approaches somewhat in character to $B$. grucilimes (Achatina) P'ir. in Wiegm. Arch. pt. I. p. 352. No. 25. (1839) Pfr. Mon. IIel. Tiv. II. p. 160. No. $418.18+5$ Rr. Cunch. Ienn. sp. 594.1849.

Stution.-Under stones, amongst fine dry earth.

Habitut.-Hill opposite Baker's, St. 'Thomas; T. B.!

17. (16.) Pupa servilis ? Cronll .Jum. Tust. Sue. IV. 1) 356.

$$
\text { t. 16.f. 14. - - } \quad 1844 .
$$

Pfr. Mon. Hel. Viv. II. p. 366.

No. 142.

1848.

Station.-Annong fine earth with decaving vegetable matter. Hebitul.-St. Croix, and Matanzas; Crunhl. Cuba; Pfeiller. Jamaica; Arlams! St. Croix; R. E. Griflith! Mus. Amh. About ruined buildings, Catharineberg, St. Thomas; T. B.!

18. (1\%.) \$ేuccinca \$agra? Orb. Moll. Cub. I. p. 141. t.

7.f. 1-3. - - - 1841. Pfr. Mon. Hel. Viv. II. p. 529.

No. 58. - - - 1848.

This appears to be identical with the Jamaica shell ( $1 \mathrm{~d}$. Contrib. 11). t0, 15t), and is probably so with that fjom Cuba.

Shetiun.-Under stones, and among dead leaves, in moist places.

Mutitut.-Cuba; Orbigny: also Pfoifter. Jamaica; Adans! St. Thomas; T. B.!

19. (18.) Helix incerta (Helienstyla) Fer. aud Desh. Mist. I. p. 221.t. 105. f. 2. - 1820-1851. Pfr. Mon. Hel. Viv. I. p. 266. No. 697. 1848. Rv. Conch. Icon. sp. $214 . \quad$ - 1851. 
Reeve is certainly in error in treating $I I$. incertu Fúr. and $I I$. lime Fér. as one species; the latter inhabits Porto Rico.

Stution.-Unknown; dead specimens only were found.

Hubitat.-St. Thomas; Férussac: also Pfeiffer. Jamaica; Reeve: corrected in Ad. Contrib. p. 20t. St. T'homas, St. John's 'I'ortola, and Anegada; Mus. Amb. St. Thomas; T. B.!

20. (19.) Helix nemoralina Pet. in Guer. Mag. de Zool. t. 80. 1836. Pfr. Mon. Hel. Viv. I. p. 281.

No. 733. - - - 1848.

A variety also oceurs, which we found dead only, at the base of the IIill opposite Baker's, St. Thomas, with a very pale brown band along the periphery.

Stution.-Unknown; (said to have been found on shrubs at Dorothea, West End, St. Thomas.)

Hulitut.-St. Thomas; Petit : also Pfeiffer: also T. B.!

\section{1. (20.) Helix —? Sp. indet.}

This somewhat resembles $H$. sincera Ad. (Proc. Bost. Soc. p. $16,18+5$, ) from Jamaica, but is more finely striated; the umbilicus is larger, and the suture not so deeply impressed. Compare also II. Lrecior (depressa antei Ad. Proc. Bost. Soc. p. 16, 1845), from Jamaica and St. Croix. The animal has the habit of attaching dirt to the shell, like $I I$. ptychorles, Pfr. Succinere arura Say, and Helicina agglutinans Sowb.

Station.-On the under side of stones; common.

Halitut.-Louisenhüi, Misgen, \&c., St. Thomas; T. B.!

\section{2. (21.) Helix — ? Sp. indet.}

A thin brown shell, with simple lip, strongly striated, width .45 inch.

S'ution.-Under stones, and among dead leaves; common.

Ilal,itut.-The garden at Baker's, dc., St. Thomas; T. B.!

23. (23.) Helix peraffinis? Ad. Proc. Bost. Soc. p. 16.

1845. Pfr. Mon. Hel. Viv. II. p. 95.

No. 237.

1848.

No. 11.-2. 
The umbiliens is rather less open than in the Jamaica shell. Station.-Under stones.

Habitat.-Catharineberg, St. Thomas; T. B.!

\section{4. (24.) Helix — ? Sp. indet.}

This is like $I$. fule Miill. (Pfr. Mon. Ecl. Tiv. p. 30. No. 36.) of Europe, and $I I$. simulares $\Lambda$ d. (Contrib. p. 35,) from Janaica; but the microseopic impressed spiral lines are much more minute than in the latter, being visible only under a very high power. Compare also the Cuba shell, $I$. Gundluctii Pfr. in Wiegm. Arch. I. p. 250, 1840.

Stution.-Among fine earth, and decayed vegetable matter.

Habitat.-Catharineberg, St. Thomas; T. B.!

On the Crausilie of America. By Thomas Bland. Oct. 1852.

The Genus Clausilia is represented in America and the Test Inclies by three species only, of which we subjoin an account.

Pfeifler in his Mon. Mel. Tiv. (18+3) describes 222 species, of which, we learn from his table, vol. ii. p. 489 , no less than 136 occur in Central Europe, and the remaining 86 as follows:-

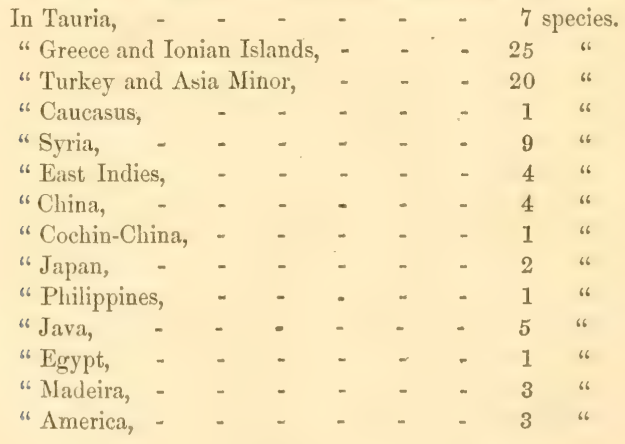


The Genus does not oceur in North America; two, C. perane and $C$. epistominm, inhabit South Anerica, and one, C. tridens, is found in the Island of Porto Rico. 'The Porto Rico species is described and figured by Chemnitz in his work, published in 1786, but Férussae first gave the correct habitat in 1821, on the authority of Mangé. C. premana was described by 'Troschel, in $A_{p}$ ril, $18+7$, as the only known American species, excepting C. tridcns, and in the same year Küuster described and figured C. epistominun.

The Genus Clunsilic was instituted by Draparnaud in 1805 , but the chusium had been described by $O$. $\mathrm{k}$. Miiller in his Hist. Vermium, Sc., 1773, and afterwards by Daubenton in the Mem. de l'Acal. des Sciences. See Mr. Gray's paper in the Zool. Journ. I. 212. We detected the clausium in six of our specimens of the $C$. epistomium, and in several of the $C$. tridens.

\section{Clausilia thidens.}

Synonymy.

Clausitia tridens

Turbo labiatus

Clausilia tridens

Hir

Clausilia costulata

Clausilia labiata

Turbo costulatus

Clausilia tridens

costulata

- labiala

costulata
(Turbo) Chem. IX. P. 1. p. 115, t. 112. f. 957 .

1786.

Dillw. Deser. Cat. II. p. 875. No. 146. in parte. (1.) - - - - 1817. Schweigg. Naturg. p. 741. teste Pfr. in Mon. Hel. Viv. - - $\quad$ - 1820.

(Cochlodina) Fir. Prod. p. 62. No. 523. 18:1. Lam. An. sans Vert. VI. pt. 2. p. 113.

No.4. - - - - - 1822.

Bowd. El. Conch. pt. 1. t. 8. f. 28. ?? (2.) 1822. Siowh. (ien. fasi. 30 Clausilia, f. 3. (3.) 1824. Wood Suppl. t. 6. f. 36. Beck. Ind. p. 90. No. 1. 1837. Desh in Lam. An. sans Vert. VIII. p. 198.

No. 4 . 1838. Pfr. Symb. I. p. 47. teste Pfr. in Mon. Hel. Viv. - - $\quad$ - $\quad$ - 1841. Rossm. XI. p. 8. No. 718. t. 52. f. 718. 1842. Rv. Conch. Syst. II. p. 77. t. 171. f. 3. (4.) 1842. Catlow Conch. Nom. p. 146. No. 40. (5.) 1845 
Clausilia tridens

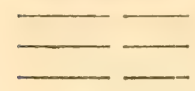

Küster Mon. p. 12. t. 1. f. 1-4. Pfr. Mon. Hel. Viv. II. p. 396. No. 1. (6.) 1848. Jay's Cat. p. 247.

Fér. et Desh. Hist. II. p. 234. No. 1. t. 166. f. 1. -

Station.-Unknown.

Ilulitat.-Spain; Chemnitz. Near London; Dillwyn. Mralta; Sowerby. Unknown; Wood. Porto Rico; Férussac: also Lannarck: also Beck: also Deshayes: also Rossmässler: also Pfeiffer : also Jay. Porto Rico, and probably other West India Islands; Küster. Porto Rico; Knox! Riise! in Mus. Amb.

(1.) Dillwyn gives the following erroneous synonymy, to which much of the confusion as to C. tridens may be attributed: "Turbo labiatus

Mont. Test. Brit. p. 362.t. 11.f. 6. (1803)

Maton and Racket, in Linn. Trans. VIII. p. 180. (1804). Dorset Cat.p. 51. t. 21. f. 15. (1813.)

Turbo tridens perversus Strombiformis perversus Da Costa Brit. Conch, p. 107. t. 5. f. 15. Bulinus perversus
Chem. IX. P. 1. 115. t. 112, f. 957 ?

Var. E. Gmelin, p. 3610 ?

Montagu, in his work (republished in Chenu. Bibl. Conch. Vol. 4. 1st series, p. 161. 18t6, ) as Syn. of T. lubiatus, has $S$. perversus Da Costa, and T. tridens Chem. but the latter with a ?: he states that he preserves the name labiatus, of which he believes Dr. Solander was the author.

Forbes and Hanley in Hist. Brit. Mfoll. vol. iv. p. 121 (1852) mention that perhaps Da Costa's figure, copied in the Dorset Catalogue, "although from its rudeness it is impossible to pronounce with certainty upon it," was drawn from the British $C$. nigricans. For a description of C. labiata (Turbo) Mont., from France and Northern Italy, vid. Pfr. Mon. Hel. Viv. II. p. 458. No. 15t. Maton and Racket, (republished in Chenu. Bibl. Conch. 2d ser. vol. i. p. 20t. 18t5.) describe Turbo labiatus, referring to Da Costa, Chem. with a ?, to Mont., and also to Olivier, Voy. dans l'empire Othoman, t. 17. f. 6. (180t). The 
Iatter author states that his shell, so figured, and called by him Bulimus teres, was collected in Crete. It is described by Pfr. as $C$. teres (Bulimus) Oliv. in Mon. IIel. Tiv. II. p. 414. No. 45.

We have not traced the B. perversus var. \&. Ginel., but the B. perversus Brug. is stated by I'fr. (in Mon. Mel. Viv. II. p. 536 with a ?,) to be a Syn. of $C$. rugosa Drap., from Spain.

(2.) It is impossible to identify the figure given by Bowdich, but it is referred to in Fér. and Desh. Hist., the latest published synonymy of $\mathrm{C}$. tridens.

(3.) Sowerby, at the foot of his plate, has Olivier as the authority for the specific name lubiuta, copied probably from Maton and Racket, without examination of Olivier's work. In the text, Sowerby gives as Syn. T. Lubrutus Mont. "from Malta."

(t.) Reere also has the name labiata on the authority of Olivier, copied apparently from Sowerby, to whose work he refers. As Syn. he also has T. labiatus Mont.

(5.) Miss Catlow, under C. costulatu Lam. refers to Sowb. Gen. f. 3. (C. Lubiutu, Oliv.) and adds as Syn., Helix bicanaliculata, Fúr. and Turbo bielens Chem., which latter is, according to Pfr. in Mon. Hel. Viv. II. p. 397. No. t., Syn. of C. laminatu (Turbo) Mont., from Europe. Under C. labiatu Oliv. (Conch. Nom. p. 147. No. 83.) the authoress has the sane reference to Suwb. Gen., adding as Syn. Helix labiatus Mont.

(6.) Pfeiffer in his synonymy of $C$. tridens refers to Dillwyn, without any qualification, thereby, in a measure, adopting the whole of his errors; and this is the more extraordinary, inasmuch as Pfeifter has precisely the same unqualitied reference to Dillwyn, as part of the synonymy of $C$. labiata.

\section{Clausilia peruana.}

\section{Synonymy.}

(Znusilia pereane Troschel in Zeitsehr. f. Malak. p. 51. April 1847. Pfr. Mon. Hel. Viv. II. p. 483. No. 204. 1848.

Station.-Unknown. 
Mutritat.-Peru; Troschel: also Pfeiffer, teste de T'schudi.

Pfilfer mentions that one specimen only was collected.

\section{Clausilia epistonniun.}

Synonymy.

Clansilia epistominm Küster Monogr. p. 13. t. 1. f. 5-8.

1847.

Pfr. Mon. Hel. Viv. II. p. 397., No. 2.

1848.

Stutim.-On rotten wood, and among dead leaves and sticks under stones, in moist shady places.

Habitat.-Marmato, (near Vega de Supia) Andes, west bank of the river Cauca, in New Granada, at elevations above the level of the sea of from five to seven thousand feet. T. B.! Central America ; Küster : also Pfeiffer, "teste Cl. Thoma."

We collected fourteen live and three dead specimens.

Cutalogne of Terrestrial Shells collected by T. Bland in New Granada, in 1851.

1. Cyclostoma giganteum Gray. Sowb. Thes. Conch. I. 92. No. 5. t. 23. f. 8. 9. 1843.

Station.-Among dead leaves, in moist places.

Ihubitat.-Mountains about Marmato (western Cordillera of the Andes); also on the mountains, (central Cordillera) east of the Paramo of Ervé, towards Fresno.

2. C. Popayannm Lea Trans. Am. Thil. Soc. VI. new series

$$
\text { p. 94. pl.'23. f. } 76 . \quad \text { - } \quad \text { - } 1834 .
$$

Station.-Among dead leaves.

Mulnitat.-Banks of the Canca, below Marmato, and east side of the Magdalena near Mendes.

3. C. Quitense Pfr. Proc. Zool. Soc. - - - - 1851. Station.-Same station.

Hubitut_-Marmato; and Santa Ana, near Mariquita. 
4. Helicina concentrica Pfr. Proc. Zoul. Soc. p. 120 Yo. 6. 1848. Station.-Among dead leaves.

Ifulitut.-Old plantain ground near the junction of the rivers Cauca and Arquia, below Marmato.

A larger variety occurred at Santa Ana.

5. Bulimus Dennisoni Rv. Conch. Teon. pl 26. f. 166 a. 166. b. 1848. Stution.-Among ferns, moss, and dead leaves, in damp places. Habitat.-Narmato.

6. B. Powisianus Pet. in Revue Zool. p. 53. - - 1845. Rv. Conch. Icon. pl. 27. f. 167 b. 167 c. 1848.

One individual laid three dark olive brown egrgs, about .3 inch in length.

Stution.-On damp banks under trees, and on shrubs.

Ifubitut.-Marmato, and the forest on the east side of the Cauca, on the road to Salamina.

7. B. Gibbonius Lea. Trans. Am. Phil. Soc. VI. new series, p. 85. pl. 23. f. 99 . - - $\quad 1834$. Rv. Conch. Icon. pl. 32. f. 197. - 1848.

Slation.-Among moist decaying vegetation.

Hulvitut.-Roadside thicket between Guaduas and Villeta.

8. B. castaneus Pfr. Proc. Zoul. Suc. 1. 68. - - $\quad 1845$. Rv. Conch. Icon. pl. 32. f. $196 . \quad$ - $\quad 1848$.

Station.-Among dead leaves.

Ifultitut.-Forest near Firesno, on the road to Santa Ana, from the Paramo of Erve.

9 B. maximus Sowb. Tank. Cat. App. p. TII. No. 973. 1825. Rv. Conch. Icon. pl. 51, f. 337 . - - 1848.

Station.-Among dead leaves, about the roots of trees in moist places.

Itulitut.-Marmato, and below it on the banks of the Cauca; also near Arma.

10. B. oblongus Miill. Mist. Term. II. p. sit.

17 it. Rv. Conch. Icon. pl. 35. f. $210 . \quad-\quad-\quad 1848$. 
Station.-Among moist decaying vegetation.

Habitat.-Santa Ana, Mendes, and Villeta.

11. B. geometricus Pfr. Symb. III. p. $84 . \quad-\quad-\quad 1840$. - Rv. Conch. Icon. pl.54. f. $278 \alpha$ - 1848. Station.-Among dead leaves.

Mabitut.-Forests in the mountains below Ervé, on the road to Santa Ana.

12. B. spectatus Rv. Conch. Icon. pl. 81. f. 601 b. - $\quad 1849$. Station.-Unknown.

Habitat.-Between Salamina and Cabuyal, west of Ervé.

13. B. linostoma? D'Orb. Syn. p. 19. - - - - $\quad 1835$. - Rv. Conch. Icon. pl. 85. f. $613 . \quad-\quad 1850$. Station.-Unknown.

Habitat.-Marmato.

14. B. Pealianus ? Lea, Trans. Am. Phil. Soc. VI. new series p. 64. pl. 23. f. 105 . - - 1834. Station.-On rotten wood. Habitat.-Near the cascade of Tequendama.

15. B. succinoides Pet. in Revue Zool. p. $75 . \quad$ - $\quad$ - 1840. also in Guérin Mag. t.31. - - 1841. Rv. Conch. Icon. pl. 52. f. $264 . \quad$ : $\quad 1848$. Station.-Unknown.

Hulvitat.-Boca del Monte, entrance of plains of Bogotà from Villeta.

16. B. nitelinus Rv. Conch. Icon. pl. 59. f. $398 . \quad$ - 1849. Station.-Among dead leaves.

Mubitat.-Marmato, and old plantain ground near the junction of the rivers Cauca and Arquia.

17. B. Gruneri Pfr. Proc. Zool. Soc. p. 30. No. $11 . \quad-\quad 1846$. - Rv. Conch. Icon.pl.51. f. 332. - - 1848.

Station.-Unknown.

Habitat.-Mendes. 


\section{CONTRIBUTIONS TO CONCHOLOGY.}

\section{Vo. 12.}

Catalogue of Terrestrial Shells collected by T. Bland in New Granada, in 1851-(Continued.)

18. B. Lamarckianus Pfr. Proc. Zool. Soc. p. 229. No. 6. 1847. Rv. Conch. Icon. pl. 24. f. 156. 1848.

Station.-Unknown.

Hatitat.-La Esperanza Estate, near Rio Negro.

19. B. Adamsoni Gray. Proc. Zool. Soc. p. 123. 1833. - - Rv. Conch. Icon. pl. 26. f. $165 a, 165$ l. 1848. Station.-Unknown.

Habitat.-One dead specimen was obtained from the late General J. Acosta, by whom it was collected, we believe, in the valley of Guaduas.

20. Streptaxis Candeana (Helix) Pet. Revue Zool. p. 177. 1842. Pfr. Mon. IIel. Viv. I. p. 7. No. 11.1848.

Station.-Unknown-dead specimens only collected.

Habitat.-Woods near Barranquilla.

21. Helix Gibboni Pfr. Symb. III. p. 37. - - - 1846. - Rv. Conch. Icon, pl. 98. f. 539. - - 1852.

_- magnifica Lea Trans. Amer. Phil. Soc. VI. new series pl. 23. f. $88 . \quad-\quad-\quad-\quad 1834$.

Station.-Among dead leaves, in moist places.

Habitat.-Marmato, also below Salamina towards the River Cauca, and near Arma.

22. H. Oreas Koch. in Phil. Abbil. I. p. 151. pl. 5. f. 2. 1842-1845.

- - Rv. Conch. Icon. pl. 99. f. 546.

Station.-Among dead leaves, in moist places.

No. $12 .-1$ 
Habitat.-Marmato, and mountains above it,-also near Salamina, and below Ervè, towards Fresno.

H. Oreas var. white, - with very thin pale brown epidermis.

Station.-Same as the last.

Habitat.-Tacon, above Marmato.

23. H. atrata? Pfr. Proc. Zool. Soc. 1850. Station.-Same.

Habitat.-Marmato and Tacon.

24. Helix subplanata? (Caracolla) Petit in Revue Zool.p. 238.18.13. " in Guér. Mag. de Zool. t. 68. 1843.

We cannot agree with Pfeiffer and Reeve in considering this to be a variety of $H$. labyrinthus Chem. It is much more nearly allied to H. plicata Born. Our shell is thin and delicate, in size like Petit's figure above referred to; the basal margin of the aperture has a lamina next the canal, and one rather broad grooved tooth beyond, with a small narrow lamina or tooth, slightly developed, some distance within the upper lip; visible on the exterior through the shell,-in which latter character it agrees with $H$. plicata Born. This last mentioned tooth is shown in Lea's figure of Carocolle Hydiana Lea, from Porto Cabello (held to be identical with H. plicata Born), Trans. Am. Phil. Soc. VI. new series, pl. 23. f. $73 a$, but is not noted in the descriptions of that shell by Pfr. in Mon. Hel. Viv. I. p. 398, or Rv. in Conch. Icon. sp. 553.

Station.-Among dead leaves.

Habitat.-Marmato.

25. Helix monile? Brod. Proc. Zool. Soc. p. 29. - - 1832. - planorbis Jay Cat. p. 112. pl. 1. f. 6, 7. - - 1839. Station.-Unknown-one dead but perfect specimen only collected.

Habitat.-Marmato. 
26. Clausilia epistomium Küster Mon. p. 13. t. 1. f. 5-8. 1847. Station.-On rotten wood, and among dead leaves and sticls under stones, in moist shady places.

Habitat_-Marmato, and Tacon.

Several undetermined and new species of Hetix, Bulimus, Achatina, and Succinea, and of Ampullaria, and other freshwater shells, were also collected.

T. B.

October, 1852.

Descriptions of new Species of Corbula from Jamaica. By C. B. Adams. October, 1852.

Mrr. Reeve's monograph of Corbula (1843-4) describes $4: 3$ species, including Potamomya. Philippi has since described 2 species in the Zeitschrift für Malak., and we have added (Catai. Panama Shells) 1 Corbula proper, and 3 Potamomyx. Omitting some of doubtful generic character, about 6 others had been previously described. Of these 55 species, 5 are from unknown babitats, 1 is from the Arctic regions, 2 from Europe, 2 from West Africa, 21 from the Indian Ocean and the adjacent part of the Pacific, mostly from the Philippine Is., 4 from New Zealand and New Holland, 15 from the Panama zoological pro. vince, 1 from Chili, 1 from the United States, 2 from the West Indies, and 2 (which are Potamomyx) from the Rio de la Plata. The 2 Corbulæ proper from the Caribbean zoological province are C. operculata Phil. from St. Thomas, and C. equivalvis Phil from Cuba.

To these we now add 10 species. We have great pleasure in: commemorating with them the names of gentlemen who, by personal collections in the West Indies, have contributed valuable materials for the subject of the geographical distribution of the Mollusca.

In the following descriptions, the larger is called the right valve, the shorter end being anterior, with the ligament a littlc: behind the beaks. This explanation appears necessary, on 
account of a different orismology in Mr. Reeve's excellent monograph.

Corbula Krebsiana. C. t. trigonâ, perinequivalvi, inequilaterali; valvâ dextrâ rostratâ; margine ventrali anticè rotundatâ, posticè rectâ: albidâ, suprì et anticè rubro tinctâ: valvâ parvâ concentricè striatâ; valvâ dextrâ concentricè sulcatâ, sulcis crebris, parvis: apicibus prominentibus, involutis: umbonibus convexis: dentibus parvis. Long. 6.1 millim.; alt. 5.1 millim.; lat. 3.8 millim.

Shell trigonal, very inequivalve, inequilateral, with the large valve rostrated; with the ventral margin rounded anteriorly, nearly straight posteriorly: white, often tinged with pink on the beaks and umbones except posteriorly: small valve finely concentrically striated; large finely and closely furrowed: beaks prominent, much involuted: umbones very convex; with small posterior angles, one on the small valve and two on the other: teeth small.

Length .24 inch; height .2 inch; breadth .15 inch.

Probably it resembles $C$. operculata Phil.

Station.-Muddy bottom, at a depth of 3 or 4 fathoms; C. B. A.!

Habitat.-In the harbor of Kingston, between K. and Port

yal; C. B. A.! About 60 specimens were obtained, most of which are less than .2 inch long.

Corbula Blandiana. C. t. crassâ, subrhombicâ, vix inequivalvi, perinequilaterali; margine anticè rotundatâ, aliunde rectilineari, posticè infrà acuminatâ: albâ: costis magnis, subacutis, concentricis, posticè minoribus; lineis radiantibus tuberculatis, microscopicis ; tuberculis deciduis; valvis ambobus simi. liter insculptis; apicibus prominulis, vix involutis: umbonibus planulatis, posticè valdè angulatis: dentibus parvis. Long. $11^{\prime \prime \prime} .2$; alt. $6^{\prime \prime \prime} .6$; lat. $4^{\prime \prime \prime} .5$.

Shell thick, subrhombic, slightly inequivalve, very inequilateral; anteriorly well rounded, with the other margins nearly 
or quite rectilinear; posteriorly and inferiorly acuminate: white: with large blunt edged concentric ribs, which are more slender in the posterior area; with microscopic radiating lines of deciduous tubercles, which are visible only under a good magnifier; with both valves sculptured alike: beaks prominent, slightly involute: umbones flattened, with a stout posterior angle: teeth rather small. Under a good magnifier a crystalline structure is very conspicuous.

Length .44 inch; height .26 inch; breadth .18 inch.

Station.-Muddy bottom, at the depth of 3 or 4 fathoms; C. B. $\Lambda$. !

Habitat.-Port Royal, in Jamaica; C. B. A.! 5 specimens were collected.

Corbula Dietziana. C. t. solidâ, valdè distortâ, juniore vix inequivalvi, seniore perinequivalvi, inequilaterali; margine anticè rotundatâ, aliunde rectilineari, posticè infrù acuminatâ: albidâ, radiis rubris, inequalibus, sæe confluentibus, in juniore obsoletis, ornatî: costis magnis, subacutis, concentricis, in seniore irregularibus et in valvâ parvâ exilibus: apicibus pro. minulis, vix involutis: umbonibus planulatis, posticè valdi angulatis: dentibus robustis. Long. $10^{\prime \prime \prime} .7$; alt. $8^{\prime \prime \prime} .4$; lat. $9^{\prime \prime \prime} .1$ : junioris, long. $10^{\prime \prime \prime} .1$; alt. $6^{\prime \prime \prime} .6$; lat. $4^{\prime \prime \prime} .3$.

Shell solid, much distorted, moderately inequivalve in the first stage of growth, afterwards very inequivalve, inequilateral ; anteriorly well rounded, with the other margins subrectilinear, posteriorly and inferiorly acuminate: whitish, with unequal often confluent bright red rays, which are indistinct in the first stage of growth: with concentric blunt edged unequal ribs. which are more irregular in the last stage of growth; with both valves sculptured alike in the first stage of growth, but in the second, the small valve is only striated: beaks prominent; slightly involute: umbones flattened, with a strong posterio: angle: teeth rather stout.

Length .42 inch; height .33 inch; breadth .36. The corre. 
sponding dimensions of a shell commencing the second stage of growth are .4 inch; .26 inch; .17 inch.

This species is remarkable for two very distinct stages of growth, with a very abrupt transition from the first to the second. Until a little more than half grown, it is very much like $C$. Blandiana in the form of the outline, in the sculpture, and in having the valves similarly sculptured, and nearly equal. In the second stage of growth, the larger valve increases nearly three times as much as the other, and the growth is abruptly and strongly directed inwards so as greatly to increase the breadth of an old shell. The sculpture is more irregular, and on the small valve it is much finer, and is covered with a coarse deciduous epidermis. Posteriorly the small valve is deeply set into the larger one. So abrupt is the change from the first to the second stage of growth, that the edge of the umbonial angle in the first makes an angle with the edge in the second of only about $115^{\circ}$, and the general form is made very irregular. It is the analogue of $C$. speciosa, which inhabits the west coast of tropical America.

Station.-Unknown.

Habitat.-Kingston harbor (Jamaica), along "the Palisades," southeast from the city; A. Barratt! C. B. A.! 22 specimens were obtained, of which several were collected by my companion Dr. Barratt, who kindly gave me nearly all his specimens of this remarkable shell.

Corbulı Swiftiana. C. t. subovoideâ, solidissimâ, inequivalvi, vix inequilaterali, postice acut̀े rostratâ; margine ven. trali excurvatâ: albidâ: rugis irregularibus et striis concentricis; junioribus exilissimè radiatim striatis: apicibus parvis, haud involutis: umbonibus perconvexis, anticè subangulatis, posticè acutè angulatis: dentibus robustis. Long. 10".4; alt. 5"'. .9 ; lat. $5^{\prime \prime \prime} .9$.

Shell subovoid, very solid, inequivalve, slightly inequilateral, acutely rostrated posteriorly, anteriorly well rounded and glo. 
bose, with the dorsal margins nearly straight and the ventral margin well excurved: whitish: with moderately developed concentric irregular ridges and strix; with the larger valve sculptured more regularly and decply than the other; with very minute radiating stria in the young: beaks small, not involute: umbones very convex, indistinctly angulated anteriorly, with a sharp but not very prominent angle posteriorly: teeth robust. It is the analogue of $C$. nasuta, which inhabits the Pacific coast of tropical America.

Length .41 inch; height .235 inch; breadth .235 inch.

Station.-Sand, in 3 or 4 fathoms water; C. B. A.!

Habitat.-St. Thomas; T. Bland! in sched. in Mus. Amb. In the east part of the harbor of Kingston, Jamaica; C. B. A.! About 250 specimens were collected.

Corbula KJgriana. C. t. C. Siciftiance simili; sed posteriùs vix rostratê, paullulum productiore: rugis concentricis robustioribus, in lunulam productis; valvis ambobus similiter insculptis: angulo umbonali acutiore, a margine dorsali plùs remotî. Speciminis magni long. $12^{\prime \prime \prime} .2$; alt. $7^{\prime \prime \prime} .6$; lat. $5^{\prime \prime \prime} .2$.

This species so closely resembles $C$. Suiftiana, that a specifcation of the differences will suffice for description. C. Kjjerianc is not so distinctly rostrated, although usually a little more elongated posteriorly: the concentric ridges are stouter, and are continued into the lunule; both valves are sculptured alike: the umbonial angle is more acute and distinct, and is a little more distant from the posterior dorsal margin.

Length of a large specimen .48 inch; height . 3 inch; breadth 26 inch.

Slation.-In mud, in 4 or 5 fathoms water; C. B. A.!

Habitat.-St. Thomas; T. Bland! in sched. in Mus. Amh. Kingston harbor, Jamaica; C. B. A.! We obtained 70 specimens, most of which are immature.

Corblia Barratriana. C. t. ovato-triangulari, subtenui, 
inequivalvi, vix inequilaterali, postice acuminatâ, margine ventrali excurvatâ: albidî rugis irregularibus parvis concentricis, in lunulam haud productis, ad valvam magnam haud multùm majoribus; junioribus exilissime radiatim striatis: apicibus parvis, haud involutis : umbonibus posticè acutè angulatis : dentibus parvis. Long. $8^{\prime \prime \prime} .9$; alt. $5^{\prime \prime \prime} .2$; lat. $4^{\prime \prime \prime} .3$.

Shell ovate-triangular, somewhat thin, inequivalve, slightly inequilateral, posteriorly acuminate, with the ventral margin well rounded: whitish: with small concentric irregular ridges, which are a little larger on the large valve, not produced into the lunule; with minute radiating strix in young shells: beaks small, not involute: umbones with an acute angle posteriorly: teeth moderately developed.

Length .35 inch; breadth .26 inch; height .17 inch.

Station.-In mud, in 4 or 5 fathoms water; C. B. A.!

Habitat.-Kingston harbor, Jamaica; C. B. A.! About 200 specimens were collected, many of which are immature.

Corbula Chittyana.-C. t. Barrattiance simili; sed multùm crassiore, latiore, inequivalviore; præcipuè differt quoad crescendi rationem duplicem, sicut C. Dietziana. Long. $8^{\prime \prime \prime} .6$; alt. $5^{\prime \prime \prime} .8$; lat. $5^{\prime \prime \prime} .2$.

This species resembles C. Barrattiana, but differs in being very thick and solid, very wide, and in having two periods of growth, like C. Dietziana: it is also more inequivalve.

Length .34 inch; height .23 inch; breadth .22 inch.

Station.-In 4 or 5 fathoms water, in a muddy bottom; C. B. A.!

Habitat.-Kingston harbor, Jamaica; C. B. A.! We obtained only 4 specimens of this rare shell.

Corbula Knoxiana. C. t. ovato-rhombicâ, subcrassâ, subequivalvi, vix inequilaterali, posticè truncatâ. et infrà acuminatâ ; margine ventrali rectâ vel haud multùm excurvatâ: albidâ: rugis concentricis reclivatis acutis regularibus, in speciminibus 
magnitudinom variantibus, ad aream posticam crebrioribus: apicibus parvis, haud involutis: umbonibus subplanulatis, posticè concavis, acutissimè angulatis ; areî posticî sulco bisectâ, a labiis angulo disjunctî; dentibus validis, brevibus. Long. $12^{\prime \prime \prime} .7$; alt. $8^{\prime \prime \prime} .1$; lat. $7^{\prime \prime \prime} .1$; spec. alterius, long. $9^{\prime \prime \prime} .4$; alt. $7^{\prime \prime \prime} .9$.

Shell orate-rhombic, moderately thick, subequivalve, slightly inequilateral, posteriorly truncated, and acuminated below, with the ventral margin straight or moderately excurved: whitish: with concentric regular acute-edged reclivate ridges, varying in size in different specimens, smaller and more crowded in the posterior area: beaks small, not involute: umbones flattened, with a very acute much developed angle, with the posterior area more or less concave and divided along the middle by a furrow, separated by an angle from the corselet: teeth short and strong.

Length .5 inch; height .32 inch; breadth .28 inch; another shell is . 37 inch long, and .31 high.

Station.-In mud, in 3 or 4 fathoms water; C. B. A.!

Habitat.-Kingston harbor, Jamaica ; C. B. A.! We obtained 2 entire shells and 20 odd valves of this rare species. It is an analogue of $C$. bicarinata of the Panama zoological province.

Corbula quadrata Hinds. C. t. subtriangulari, tenui, (inequivalvi ?) perinequilaterali, anticè brevissimâ, posticè suprà excurvatî et infrà subacuminatî; margine ventrali subrectâ: albâ: concentricè irregulariter striatâ, exilissimè granu. latî: apicibus parvis, haud involutis: umbonibus planulatis, posticè angulatis : angulo acuto, editissimo ; areâ posticâ magnâ, concarî̀; dentibus gracilibus. Long. $11^{\prime \prime \prime} .4$; alt. $8^{\prime \prime \prime} .9$; lat. $7^{\prime \prime \prime} .1$.

Shell subtriangular, thin, (inequivalve?) very inequilateral, the anterior part being very short, posteriorly well rounded above and subacuminate below; ventral margin nearly straight: white: sculptured only with fine irregular strie of growth, and with microscopic granules except on the posterior third: beaks small, not involute; umbones flattened, with an acute exces- 
sively prominent posterior angle, behind which is a large concave area: teeth prominent, not robust.

Length .45 inch; height .35 inch; breadth .28 inch.

Station.-Unknown.

Habitat.-Unknown; Hinds: also Reeve. St. Thomas; T. Bland! in sched. in Mus. Amh. We have only 5 odd valves; the relative size of the valves is therefore doubtful.

Synonymy._C. quadrata Ilinds, in Proc. Zool. Soc. Lond. p. 57. - - - - May 1843. Reeve Conch. Icon. pl. 5, f. 40. May 1844.

After the brief descriptions by Mr. Hinds and Mr. Reeve, additional description may not be wholly useless. The figure given by Mr. Reeve exactly represents our specimens even to the irregularity of the umbonial angle, which appears as if actually distorted by the compression of the upper part of the umbo.

Corbula Newtoniana.-C. t. obovata-rhombicâ, tenui, (inequivalvi?) perinequilaterali, anticè brevissimâ, anticè et posticè excurvatâ; margine ventrali rectâ: albâ: concentricè irregulariter et exilè striatâ: apicibus parvis, haud multùm editis, haud involutis: umbonibus subangulatis; dentibus gracilibus. Long. $12^{\prime \prime \prime} .7$; alt. $8^{\prime \prime \prime} .6$; lat. $7^{\prime \prime \prime} .9$.

Shell between an obovate and rhombic form, thin, (inequivalve?) very inequilateral, the anterior part being very short, anteriorly and posteriorly well rounded; ventral margin straight: white: with fine irregular striæ of growth: beaks small but somewhat prominent, acute, not involute: umbones with an obtuse angle extending diagonally through the posterior half of the disk; teeth prominent, not robust.

Length .5 inch; height .34 inch; breadth .31 inch.

Station.-Unknown.

Habitut.-St. Thomas; T. Bland! in sched. in Mus. Amh. We have only 4 specimens of the left valve.

Corbula fulva.-C. t. ovato-triangulari, crassâ, (inequi- 
valvi?) vix inequilaterali, postic̀ subrostratî ; margine ventrali excurvatî: fulvâ, intus roseo tinctî: concentricè suprì striat $\hat{a}$, infrì fortiter sulcat $\hat{u}$ : apicibus parvis, haud involutis: umbonibus perconvexis, posticè biangulatis: dentibus mediocribus. Long. 7"'.9; alt. 5"'.6; lat. $5^{\prime \prime \prime} .1$.

Shell ovate-triangular, thick, (inequivalve?) subinequilateral, subrostrated posteriorly; ventral margin excurved: yellowish brown, tinged with red within: striated above, and strongly furrowed below, concentrically: beaks small, not involute: umbones very convex, posteriorly biangulated: teeth moderately developed. It differs from $C$. Suiftiana in being less rostrated; it is also shorter than C. Kjoeriana; and differs from both in color, and in being very strongly sulcated. We have therefore ventured to describe it from a single right valve.

Length .31 inch; height .22 inch; breadth .21 inch.

Station.-Unknown.

Habitat.-The specimen (in Mus. Aml.) was said to have come from the Amazon; but the species is not a Potamomya.

Journal de Conchymiologie, comprenant l'étude des Animaux, des Coquilles viechntes ct des Coquilles fussiles, publié sous la direction de MI. Petit de la Situssaye. - IVe desire to eall the attention of Conchologists to this valuable journal. The first volume, published at Paris in 1850 , contains 140 pages, with 15 plates, and the second volume, published in 1851 , has 414 pages, with 12 plates. Parts 1 and 2 of the third volume were issued in April and June of the present year, and have together 240 pages, with 8 plates. The plates are beautifully executed, and consist of figures of fossil and recent shells, the latter coloured, with anatomical drawings of the soft parts of some species. The articles in this Journal, contributed by D'Orbigny, Petit, Recluz, Moricand, Morelet, and other eminent scientific men, are very interesting. 'The last number contains, among other 
papers, anatomical descriptions of the animal of Ancylus fuviatilis, and of the animal of Glandina-the former by Mr. MoquinTandon, the latter by M. Morelet: also descriptions of various new species of Mollusks, and a Catalogue of the marine shells of the coasts of France. The price of each volume of the Journal is $18 \mathrm{fr}$. Address M. Petit de la Saussaye, Rue neuve des Mathurins No. 19. Paris.

T. B.

Memorias sobre la Historia Natural de la Isla de Cuba, acompañadas de sumarios latinos y extractos en francés. By Felipe Poey. Havana, 1851. - The two first parts of the first volume of this work have been published, and contain 16 fine plates, some of them highly coloured, with 120 pages of letterpress. Of the plates, 2 are of mammalia, 5 of fishes, 3 of insects, and 6 of land shells. The first part contains, on the subject of Conchology, an introductory article on Terrestrial Univalves, and the second, an article on the Genus Cyclostoma, with general remarks on Gasteropods, and particularly on terrestrial operculated shells, followed by descriptions of ten new species of Cyclostoma, a note on $C$. tortum Wood, and also descriptions of thirteen species of Helicina. We hope that this undertaking will meet with the liberal encouragement which it deserves. The author proposes to complete the work in 24 parts, to be issued periodically, the last by the end of 1854. The price of each part at Baillière's, Broadway, New York, is $\$ 250$.

T. B.

Catalogue of SPECIES OF LUCINA, which inhabit the WEST INDIAN Seas. By C. B. Adaurs. November, 1852.

The genus Lucina contains about 90 known species, of which 69 are described in Mr. Reeve's monograph. The following list of 20 West Indian species is presented chiefly as a vehicle for some miscellaneous statements respecting the nomenclature, and the habitats of some of them. 


\section{Lucina Americana. Nov. sp.}

L. t. Lucince divaricate simili; crassiore, majore; striis profundioribus ornatâ ; lunulâ minimâ, elongatâ, sinuosâ ; marginibus exilissimè crenulatis, haud serratis. Long. 19.8 millim.; alt. 19.6 millim.; lat. 12.7 millim.

We wish to call the attention of geologists and of others, who have believed in the great geological antiquity and the wide geographical distribution of the so-called $L$. divaricata, to the just remark of Philippi (Zeit. f. Mal. 1818. p. 151): "nomine L. divaricata plures species confusie, omnes divaricatim striatæ." When the types shall have been properly distinguished, we believe they will be found to have the ordinary restriction both in time and in area. The Linnæan name should be reserved for the Mediterranean species, since Linnæus assigns his shell to a Mediterranean habitat.

L. eburnea $R v$., from the west coast of tropical America, resembles this species more closely than does any other Atlantic species, but differs in having a more distinct and cordate lunule, and in having the strix more arcuated. The beaks of our shell are not oblique as in $L$. ornata $R v$.

Habitat.-Coney Is., New York; C. B. A.! and Jamaica; C. B. A.! St. Thomas; T. H. Newton! in Mus. Amb.

2. Lucina Anatellinoides Reeve, Conch. Icon. "Habitat.-West Indies;" Reeve.

\section{Lucina Antillarum Reeve, Conch. Icon. Aug. 1850.}

This species was described by me, under the name of $L$. ornata, in a paper read before the Bost. Soc. Nat. Mist. May 5, 1847. This name occurs in the published record (Proc. vol. ii. p. 228), but the description of this and of several other species appears to have been overlooked in publication. The species was also included, with the same name, in my Catalogue of North American Shells, Jan. 1, 1847. Subsequently Mr. Reeve has given the same name to another species; but both of $\mathrm{Mr}$. R.'s names must stand. 
Habitats of specimens in the Mus. Amb.; Guadaloupe; Petit. St. John's I. ; E. Ilartwig! St. Thomas; T. Bland ! : also Krebs ! Jamaica; C. B. A.! West Indies; S. Hovey !*

4. Lucina aurantia Desh. Encyc. Meth. Vers. 1830. Tb. in Lam. An. sans Vert. 1835. Menke in Zeit. f. Mal. 1849. Reeve Conch. Icon. 1850.

Habitat._- "Nous la eroyons des mers de l'Inde;" Deshayes. "Cuba and St. Thomas;" Menke. "West Indies;" Reeve. Of specimens in Mus. Amh.: St. Thomas; Krebs! W. Indies; S. Hovey!

5. Lucina Chemnitzii Phil. Zeit. f. Mal. 1848. L. divaricala Reeve (non Linn.) Conch. Icon. 1850. An L. serrata Orb.?

Habitat of specimens in Mus. Amb.; St. Thomas; Krebs! West Indies; S. Hovey!

\section{Lucina edentula (Venus) Linn.}

Habitats of specimens in Mus. Amh.: St. Thomas; Krebs! Porto Rico (red var.); Hartwig. Jamaica; C. B. A.! West Indies; S. Hovey! An odd valve is 3 inches long and 2.9 inches high.

7. Lucina exasperata Reeve, Conch. Icon. Aug. 1850. L.tigerina Lam. var. 3.

Several large specimens of this species, now in the Mus. Amh., were said to have been collected by the Rev. Henry Lyman, in the East Indies, on his way to Borneo, where he was killed by the savages. If Lamarck's statements of habitat were more reliable, we might suppose, therefore, as his $\mathrm{L}$. tigerina is said to inhabit "l'océan Indien et Americain," that this was his East Indian type. But Mr. Reeve quotes Dyson as an original collector of the shell in Honduras.

8. Lucina funiculata Reeve, Conch. Icon. 1850.

Habitat._"Honduras; Dyson!" Reeve.

* Professor Hovey's collections were made chiefly in St. Croix and Antigua. 
9. Lucina granulosa Ad. Proc. Bost. Soe. Nat. Iist. Jan. 1, 1845. Mabritats of specimens in Mus. Amb.: St. Thomas; T. Bland! Jamaica; C. B. A.!

10. Lucina imbricatula $\Lambda$ d. Proc. Bost. Soc. Nat. Mist. Jan. 1, 1845. L. pecten Reeve, Conch. Icon. pl. 7. f. $34,35 a$ (35 b excl.) June 1850. L. occidentalis Reeve, Conch. Icon. Aug. 1850. L. pecten Petit in sched.

Hatitat.-"I. of St. John, W. Indies; Hartwig! Lord IIood's I.; Cuming!" Reeve. Has not Mfr. R. confounded with our species a Pacific analogue? Of specimens in Mus. Amh.: Guadaloupe; Petit. St. John's I.; E. Hartwig! St. Thomas; Krebs! Jamaica; C. B. A.; in 2 to 4 feet of water. West Indies; S. Hovey!

\section{Lucina Jamaicensis (Venus) Chem.}

Hatitats of specimens in Mus. Amb.: San Juan de Nicaragua; Krebs! Carthagena; Krebs! St. Croix; E. Hartwig! St. Thomas; Krebs! Jamaica; C. B. A.! West Indies; S. Ilovey!

\section{Lucina Janeirensis Reeve, Conch. Icon. June 1850.}

In the Catalogue of North American Shells (Jan. 1, 1847), this species appeared with the name $L$. lupinus Broc. on the authority of Prof. Brown. Finding that it was distinct, I described it before the Bost. Soc. N. II., May 5, 1847, with the name of $L$. subglobosa, which was inserted in the Proceedings. But the description having been omitted, as before stated, Mr. Reeve's name must stand.

Halitat.- "Rio Janciro;" Reeve. Of specimens in Mus. Amb.: St. Thomas; Krebs! Jamaica; C. B. A.!

13. Lucina pectinata Ad. Catal. N. Amer. Shells, Jan. 1, 1847.

This is another of the species of which the name only occurs in the Proc. Bost. Soc. May 5, 1847. It does not appear to have been described elsewhere.

L. t. Lucinæ pectini affini, sed perobliquâ, posticè declivi, exilissimè concentricè striatâ; costis radiantibus latioribus, pluribus 
bi- vel tri-furcatis. Long. 18.8 millim.; alt. 13 millim.; lat. 10 millim.

It must also resemble $L$. obliqua Reeve, said to have been collected by Benson at Chusan. But in that shell, the concentric and radiant lines are described in the same terms, and the posterior margin is figured as broadly subtruncate.

Habitat.-Jamaica; C. B. A.! It is found, rarely, among collections of West Indian shells.

\section{Lucina pectinella Ad. Nov. sp.}

L. t. suborbiculari, margine dorsali subrectâ, marginibus alteris rotundatis; costis radiantibus planulatis, subapproximatis, nonnullis angustè bifurcatis, ad extremitates nullis; lineis elevatis concentricis regularibus, costas superantibus; striis concentricis intermediis microscopicis; lunulâ conspicuâ, cordatâ, subelongatâ; limbo interno a costis pectinato ; dentibus lateralibus magnis. Long. 7.8 millim.; alt. 8.1 millim.; lat. 2.8 millim.

Dredged in 4 or 5 fathoms, in soft mud, in the harbor of Kingston, Jamaica ; C. B. A.!

\section{Lucina Pennsylvanica (Venus) Linn.}

Habitats of specimens in Mus. Amh. : St. Thomas; E. Hartwig!: also Krebs! W. Indies; S. Hovey! Jamaica; C. B. A.! Yucatan; Largilliert.

\section{Lucina pilula Ad. Nov. sp.}

L. t. Lucince divaricatce affini; sed minore, crassiore, globosâ; apicibus prominentibus, haud obliquis; lunulâ parvâ, subde. pressâ, subcordatâ; striis divaricatis crebris, radiantibus microscopicis, evanescentibus; limbo crenulato. Long. 10.7 millim.; alt. 9.9 millim.; lat. 7.3 millim.

The lunule is not elongate as in L. Americana, and the marginal crenulations are stronger, and the depressions between them are prolonged into the interior.

Habitat.-We have received 2 specimens from M. Krebs as West Indian shells. 
17. Lucina scabra Reeve (Lam.?)

Lamarck cites Tellina muricata Chemn. in his synonymy of L. scabra, without assigning any reason for changing the name. Mr. Recve uses the Lamarckian name for this West Indian speeies, but applies the Chemnitzian name to a Peruvian species obtained by Mr. Cuming.

Habitat,-One large and several smaller specimens were obtained with $L$. pectinella.

\section{Lucina soror Ad. Nov. sp.}

L. t. suborbiculari: margine superiore anticè et postici declivi, inferiore anticè subarcuatâ: cinereo-albidâ; microscopicè crèberrime punctulatî ; striis encentricis exilissimis creberrimis: umbonibus prominentibus: apicibus subobliquis: lunulâ minulissimâ: limbo simplici; dentibus lateralibus obsoletis. Long. 19.6 millin.; alt. 18 millim.; lat. 12.7 millim.

Except in form, it resembles l. . Ineirensis. It was obtained with I. pectinella.

\section{Lucina tigerina (Venus) linn.}

Halritats of specimens in Mus. Amb.: St. Thomas: H. Hart. wig! : also T. Bland! : also П. Krebs! W. Indies; S. Hovey! Iamaica: (C. B. A.! Bermudas: J. H. Redfield MS.; also C. U. Shepard MS.

20. Lucina virgo Reteve Conch. Icon. June 1850.

Mulvitut.- - - Reeve. With this species we doubtfully identify rertain shells from . Iamaica and the other West Indies. 


\section{ERR $\Lambda^{\prime} \Lambda$.}

This list of errata includes chieny errors of typography or of grammar. Some errors in the synonymy and in the limitation of species have not been corrected, but may be noticed in a final work on the land shells of Jamaica.

On p. 3, 6th line from the bottom, after old insert shells.

Pages 1-8 of No. 2 should De paged 17-24.

On p. 19, 8th line from the top, after whorl insert except.
" 30,4 th
"6 for fine read five.

632,9 th

the bottom, for fine read five.

"25, 1st line at the top, for Plillipiana read Philippiana.

"6 39,4 th line from the bottom, for Phillipiana real Philappiana.

"40,5th " " " top, for abberrans read abcrrans.

"40,3d " " " bottom, for Spengleri Hinds read Spengleriana Pfr.

"47, 14 th " " " dele $H$. hamastoma Moric. and of.

"4 47, 11th "6 "6 "6 for twoo read one.

"47, 10th "6 "6 for third read sccond.

"48,9th " " " top, dele of before $\gamma$.

" 50,5 th " " " bottom, for the West in read in the West.

" $51,2 \mathrm{~d}$ " " " " for hamastoma .Moric. read aurantia Gray.

46 63,10 th "6 "6 top, for $R v$, read $K n r$.

"69,2d "6 "6 " before 1850 insert Feb.

"78, 16 th " " " " " for Schroeteri read Schroctcriane.

" $88,2 \mathrm{~d}$ ": " "

" 88,15 th " " " " for costulosa read costulosus.

" 135,14 th and 15 th lines from the top, dele the quotation marks.

" 137,1 st line at the top, for rugodens rend rugosc and.

"6 139, dele the 13 th line.

"141,3d line from the bottom, for corresponding read correspond.

"142, 11th line from the bottom, for Jamaicensis read Jamaicense.

The deseription of I:alimus immaculatus was onitted trom p. 99. The anthorship of this name must therefore be ascribed to Mr. ReEve, who subsequently adopted it in the Conchorogia IConica. 


\section{N I) E X.}

[Names of families and of more comprebensive groups are in SMALL CApITALs. All symonyms, and names of species and genera not first described in this volume, are in italics. Names of new species and genera regarded as valiel, are in Roman letters. Synonyms introduced by the suthor are referred to the valid names of the species.]

Achatina,

aberrans Pfr. v. Spiraxis a. 40, 52,

88,184

angiostoma Ad. $\quad 25,39,103,183$

anomala $\Lambda$ d. v. Spiraxis a.

arcuata Pfr:

Blandiana Ad.

costulata $\mathrm{Ad}$.

costulosa Ad.

curvilabris $\mathrm{Pfr}$.

Dominicensis Gmel. 39, 48, 177, 183

elegans $\Lambda$ d.

Gayana Ad.

Giossei Pir.

gracilior $\Lambda$ d.

Grifithii $\Lambda$ d.

Grifithsii dd.

Ingallsiana Ad,

39,183

$83,167,183$

40,184

102,184

39,184

inusitata Ad. $\nabla$. Spiraxis i. 26,40 , 87,184

iote Ad.

Jamaicensis $\mathrm{Pfr}$.

$40,52,53,184,219$

leuco onias Walch, 24,39, 48, 177 ,

levis $A d$.

ligata $A$ d.

longispira $\mathrm{Ad}$.

micans $A d$.

nemorensis Ad. var. a. $\mathrm{Ad}$.

nitidn $A$ d.

octona Chem.

osculans Ad.

pellucens $\Lambda$ d.

perplexa $\Lambda d$.

P'erueviana $\mathrm{F}$.

Philippiana Pfr.

l'hillipsii Ad.

procera $\Lambda \mathrm{d}$.

propinqua $\Lambda d$.

proxima $\Lambda$ d.

puella $\Lambda$ d.

similis $\Lambda d$.

solitaria $\Lambda d$.

striosa $\mathrm{Ad}$.

tenera Ad.

unicolor Ad.

$26,40,90,184,219$

84,184

204

$25,39,183$

$39,104,183$

$21,39,188$

$40,83,84,183$

167,183

83,183

103,183

168,183

$26,40,167,184$

104,183
Aclatina venusta $\mathrm{Ad}$.

var. $\gamma \mathrm{Pfr}$.

var. unicolor $\mathrm{P} f \mathrm{r}$. vicina Ad.

Achatinella abbreviata Rv. castanca I?v.

decepta Ad.

Dimondi Ad.

var. lata,

magna Ad.

modestr $A d$.

pulcherrima Swain.

radiata $\mathrm{P} f \mathrm{f}$.

Reevii $\Lambda d$.

rubens Gould,

Tappaniana $\Lambda$ d. var. dubiosa Ad. viridans Migh. Rv.

Ampullaria fasciata Iam.

204

242

fuviatilis Mïll.

39,183

48

177

40, 184

128

128

127

126

127

125

128

128

128

128

127

126

126

128

8

242

204

188

$26,40,181$

ANNelides,

187

200,201

200

104, 183 Aplysia,

$26,40,181$ Argonauta,

25, 39, 103, 183 Argonavtid. F,

25 Ariovid.

103, 183 Articulata,

$197,198,200$

199

200

197

200

42,186

104, 184 Auricula monile Lam.

42,186 nitens Lam.

Brachioroda,

BucCINID.F,

$197,198,199,201$

Buccinum concinnum $\mathrm{Ad}$.

200 obesum Ad.

pulchellum Ad.

55

55

Bulimus,

130

Adamsoni Gray

231

anomalus Ad. v. Spiraxis a. 28,40 ,

badiosus (Helix) Fer.

168

baticatus (Helix) Fer.

216

Caribcorum Lam.

216

castaneus Pfr. 
Bulimus Dennisoni Reeve,

Dysoni Pfr.

crubescens Pfr.

exilis (Helix) Gmel.

var, trifasciatus $P f$.

geometricus Pfr.

Gibbonius Lea,

Gossei Pfr.

gracillimus $\mathrm{Pfr}$.

Gruneri Pfr.

Guadaloupensis Brug.

hortensis Ad. v. B. subula Pfr.

immaculatus Reeve,

Kieneri Pfr.

lceviusculus Ad.

Lamarckiumus Pfr.

linostoma Orb.

macrospira Ad.

maximus Sowb.

minimus $\mathrm{Ad}$.

mirabilis Ad. v. Spiraxis m.

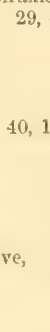

monodon $\mathrm{Ad}$.

nitelinus Reeve,

nitidiuseulus Ad.

oblongus Müll.

octonoides Ad.

octonus Lam.

pallidus Ad.

pauperculus $\mathrm{Ad}$.

Powisianus Pet.

procerus Ad.

rubrifasciatus Reeve,

rufescens Gray,

spectatus Reeve,

striatcllus Ad.

subula Ad. (non Yfr.) v. B. pro-

$$
\text { " Pfr. }
$$

$$
\text { cerus, }
$$

succinoides Pet.

terebella Ad.

teres Oliv.

turricula Pfr.

undatus Brug.

unicarinatus (Pupa) Lam.

virgulatus Fer.

zebra Müll.

Bulinus perversus Brug.

Bulle,

Carinaria,

Carocolla Hydiana Lea,

Cernalotoda,

Cerithium albo vittatum $\Lambda \mathrm{d}$.

dealbatum $\Lambda$ d.

decoratum $\Lambda$ d.

exiguum $\mathrm{Ad}$.

exile Ad.
Cerithium flavum Ad.

fusiforme Ad.

40, 184 gemmulosum Ad.

219,220 intermedium Ad.

latum Ad.

megasoma Ad.

$23,182,218$

222

230

219,220

$168,184,221$

40,184

218

$40,48, \begin{array}{r}184 \\ 231\end{array}$ 231 230

169,184 229

$28,40,52,184$

$29,40,168,184$

$28,40,184$ 230

$27,40,184$ 229

184 218

40,184

$27,40,184$

184,229

229
229
219

$40,176,184$

230

40,184

pro-

184

221

230

$28,40,184$,

227

218

184

218

220

$40,48,184$

226,227

200

197,200

232

197, 199

122

117
117

117
118

118
120

melanura Ad.

mirabile $\Lambda$ d.

modestum Ad.

nanum Ad.

ornatum Desh.

pulehellum Ad.

rugulosum Ad.

versicolor Ad.

vicinum Ad.

Chemnitzia exilis Ad.

flavocincta Ad.

latior Ad.

levis $\mathrm{Ad}$.

multicostata Ad.

obeliscus Ad.

puncta Ad.

pusilla Ad.

reticulata Ad.

substriata Ad.

subulata Ad.

Cuitonip:

Cingula concinna Ad.

conies Ad.

solida Ad.

Clausilia,

costulata Lam.

epistomium Küst.

labiata Sowb. " Oliv.

nigricans Jeff.

Peruana Trosch.

rugosa Drap.

costulata Ad.

decipiens Ad.

dormitor Sowb.

fenestrata Ad.

obesa Ad.

oruloides Ad.

purpurascens Ad. pygmaa Sowb.

Conchifera,

Conus armillatus $\mathrm{Ad}$.

Corbula,

Barrattiana Ad.

Blandiana Ad.

Chittyans Ad.
Choanopoma,

laminata (Turbo) Mont.

tridens Chem. 225, 226, 227
Columbella atomella Duclos,

Page

122

120

120

119

122

119

117

118

117,119

117

117,119

121

121,122

119

122

74

74

72

73,74

74

72

72

74

75

73

$7 \%$

200

88

70

70

70

211, 224, 225

225,227

$225,228,233$

$225,226,327$

227

227

226

225,227

227

bicarinata Sowb.

\section{8}

55

55

57
$197,198,201$ 
Corbula Dietzinna Ad. equivalvis Phil.

fulva $\Lambda \mathrm{d}$.

Kjœriana $\Lambda$ d.

Knoxiana Ad.

Krebsiana Ad.

nasuta Sowb.

Newtoniann Ad.

operculata Phil.

quadrata Hinds,

speciosa Hinds,

Cyclas,

Swiftiana Ad.

pygman Ad.

Crelostomid.e,

Cyclostoma,

aculeosum Ad. v. C. Hillianum,

$2,15,84,179$

Adamsi Pfr.

album Lam.

a. var. fuscum Ad.

$16,47,139,180$

$15,156,180$

156,180

$2,15,179$ amabile Ad.

amandum Ad. พ. C. scabriculum,

$$
3,15,89,154,179
$$

ambiguum Deless. non Lam. 15, 180 anomalum Ad. $\quad 88,90,154,179$ Antillarum Sowb.

srmatum Ad.

$10,11,16,180$

articulatum Sowb. F. C. muta-

tum,

$15,47,154,179$

asperulum Sowb. 16, 176, 178, 180 Augustre Ad,

$7,15,155,180$

a. var. nitens Ad. $8,15,155,180$

b. var. testudineum Ad. 155,180

c. var.rufilabre (a) Ad. $8,155,180$ aurora Ad.

avena $\Lambda d$.

Banksiamum Sowb.

$11,16,177,180$ $6,15,51,180$

$10,15,156,177,180$ var. hyacinthinum $\mathrm{Ad}$.

$9,15,156,177,180$

Binneyanum Pfr.

Blandianum Ad.

$129,17 ! 9$

Bronnii Ad.

$3,15,179$

15,180

a. var. fuscolineatum Ad. 15,180

Campbellii Ad.

Chevalieri Ad.

154,180

a. var. album Ad.

155,180

Chittyi $\Lambda$ d.

156,180

columna Wood,

$1,15,89,179$

concentricum ₹. C. variabile,

$4,15,154$

corrugatum Sowb.

$16,140,142,143,176,180$

crassum Ad.

143,180

crenulatum Gray,
Cyclostoma erenulosum $\Lambda$ d: $12,15,180$ decussatulum Ad.v. C. mirabile,

$4,15,177,179$

157,180

dubiosum $\Lambda$ d.

16,180

Duffianum Ad.

fascia Gray,

a. var. proximum $\mathrm{Ad}$.

$8,15,155,180$

fecundum Ad.

$11,16,180$

a. var. distinctum $\Lambda \mathrm{d}$. 11, 180

filosum Sowb.

154

fimbriatulum Sowb. 1, 15, 89, 179

a. var. docens Ad. $\quad 140,179$

b. var. allinodatum Ad.139, 179

giganteum Gray,

granosum Ad.

$93,140,179$

a. var. aberrans Ad. 140,179

Grayanum Pfr.

Grifitithianum Ad.

$4,15,179$

93,180

Ifillianum Ad. $15,84,153,179$

a. var, aculeosum Ad.

$2,15,84,179$

b. var. leporilabre Ad. 153,179 hyacinthinum Ad.v. C. Banksi-

anum,

$9,15,158$

Humphreysinnum Pfr.

180

ignilabre Ad. $\quad 9,15,155,180$

a. var. albilabre $\Lambda$ d. $9,155,180$

intermedium $\mathrm{Ad}$.

$5,15,179$

interruptum Lam. non Deless. 180 Jamaicense Chem.

$16,140,142,143,180$

Jayanum Ad. $50,89,155,180,194$

a. var. rufilabre Ad. $7,155,180$

b. var. nigrilabre Ad. 89,180

jugosum Ad.

143,180

labeo Jü̈ll.

lamellosum $\mathrm{Ad}$.

$15,176,180$

138,180

lima Ad.

$3,15,179$

lincinellum Lam. 15, 153, 177, 179

lincinum Linn.

maritimum $\Lambda d$,

mirabile Wood,

mirandum Ad.

modestum Ad.

monstrosum Ad.

mordax $A d$.

moribundum Ad.

MLussonianum Ad.

mutatum Ad.

mutieum Ad.

Neweombinnum Ad.

$15,140,179$

16,180

$4,177,179$

$4,15,179$

$6,15,139,180$

$5,15,179$

$12,16,180$

$5,15,179$

153,179

154,179

$11,16,180$

$8,15,177,180,203,218$

nitens Ad. v. C. Augustx, 8,155

nodulosum Ad. v. C. granosum,

obscurum Gray,

$91,140,179$

pallescens $\mathrm{Ad}$.

15,179

143,180 
Cyclostoma papyracerm Ad. 09 a. var. abbreviatum Ad. 157,180 pauperatum Ad. perpallidum Ad. pictum Sowb.

pisum Ad.

I'opayanum Lea,

157,180

$7,15,180$

$9,15,154,17 !$

proximum Ad. v. C. fascia 8,15

pulchrius Ad.

pulchrum Wood,

$15,129,179$

quinquefasciatum Ad. T. C. co-

lumna,

$12,15,180$

Quitense Pfr.

228

Redfieldianum Ad.

retrorsum Ad.

sagittiferum Ad.

$10,15,180$

$91,154,179$

137,180

Saulice Sowb. $\quad 16,47,109,180$

scabriculum Sowb. 8, 15, 89, 154, 179

scalarinum Villa.

194

seminudum Ad.

sericinum Ad.

serriferum Ad.

Shepardianum Ad.

simulans Ad.

solidum Ad. v. C. Jayanum,

$$
7,15,50,180
$$

spinulosum Ad. v. C. lincinellum,

$$
1,15,153,154,177,179
$$

subrugosum Sowb. 141, 143, 180

succineum Sowb.

suturalc Sowb. 108, 142, 157, 180

Swiftianum Newcomb, 203, 216

Tappanianum Ad. $157,177,180$

tectilabre Ad. $\quad 1 \hat{v}, 15,138,180$

tenuistrintum Ad. $\quad 8,15,139,180$

thysanoraphe Sowb. $\quad 15,180$

tortum Wood,

'Troscheli Pfr.

203,216

variabile $A$ d. $\quad 3,4,5,15,154,179$ a. var. concentricum Ad.

varians $\Lambda \mathrm{d}$.

$4,15,154,179$

Vilkinsonii Ad.

143,180

virgineum Ad.v.C. pisum, 20,154,179

xanthostoma Sowb. 9, 15, 155, 180 a. var, albilabre $A d$. $\quad 155,180$ Yallahense Ad.

156,180

$2 \frac{1}{4}, 211$

Cylindrella,

Agnesiana Ad. $\quad 19,39,160,182$ var. diminuta Ad. 160, 162, 182

alabastrina Pfr.

$39,176,182$

alba Ad.

$20,39,182$ var. striatula $\mathrm{Ad} . \quad 20,182$

ambigua Ad. v. C. rosea

21, 39

aspera $\Lambda \mathrm{d}$.

$21,29,39,183$

Augusla Ad. v. C. Hollandi

Beardsleann Ad. v. Geomelemint

Ii.

$19,39,52,89$
Cylindrella Binneyana Pfr.

brevis Pfr. 22, 39, 47, 90, 177, 183 var. obesa Ad. $\quad 22,39,183$ var. columna $\mathrm{Ad}$. $\quad 22,39,183$ var. intermedia Ad. 22, 39, 183 carnira Ail. $22,2,:, 4,183$ var. cerina Ad. $\quad 22,39,183$ Chemnitziana (Helix) Fer. $\quad 182$ columnn Ad. v. C. brevis, 22,39 costulata Ad. $\quad 20,27,39,182$ costulosa Ad. $\quad 98,182$ Cumingii Ad, r. C. elongata 182 cylindrus Ad. v. C. rubra 23 Chem. 39, 102, 161, 183 densestriata Ad. v. C. Urevis 22 Dunkeri Pfr. $\quad 23,39,102,167,183$ elatior Ad, $\quad 167,183$ clongate Chem. $\quad 39,182$ Gossei Pfr. $\quad 39,182$ gracilicollis (IIelix) Fer. $\quad 216$ gracilis Wood, 39, 182 Gravesii Ad. 21,39, 183 a. $\mathrm{var}, \mathrm{Ad}$.

Greyana Ad. v. Geomelania G. 82 Hollandi Ad.

82,183 a. var. Augusta Ad. 83,183 Humboldtiana var. $\beta$ Pfr.

humilis Ad. $39,47,176,182$

Hydeana Ad. inornata $\mathrm{Ad}$. 101,183 lata Ad. $28,39,182,218$ $22,39,183$ $82,161,183$ a. var. producta $\mathrm{Ad}$. 161,183 Kieneri (Bulimus) Pfr. 221 Mangeri Wood, 39, 47, 161, 166, $167,182,191,216$

var. $a \mathrm{Pfr}$. 163 var. $\beta$ Pfr. 165 var. $\gamma$ Pfr. 164

a. var, nigrescens Ad. 162,182 b. var. solida Ad. $\quad 162,182$ c. var. levis Ad. $\quad 162,182$ d. var, tricolor Ad. 163,182 c. var. crassa Ad. $\quad 163,183$ f. var. unicineta Ad. 163, 183 g. var. bicincta Ad, 164,183 h. var. concinna Ad. 161, 183 i. var. sinuata $\mathrm{Ad} \quad 161,183$ j. rar. rufilabris Ad. 161,183 k. var. citrina $\mathrm{Ad}$. $164,165,183$ l. var. fusiformis Ad, 164,183 m. var. albida Ad. 165,183 n. var. valida Ad. 165,183 o. var. unicolor $\Lambda$ d. $\quad 165,183$ p. var. striatula 4 d. 165,183 q. var. striata Ad. 165,183 r. var. corpulenta Ad. 165,183 s. var. fusea $\mathrm{Ad}$. 165, 183 
Cylindrella Mrugeri,

t. var. conica $\mathrm{Ad}$,

u. var. tesselata Ad.

v. var. einerea Ad.

w. var. gracilis Ad.

$\mathbf{x}$. var, integra $\mathrm{Ad}$. montana Ad.

nobilior Ad.

$20,39,83,183$ $39,129,183$

obesa $\Lambda$ d. $\mathrm{v}$. C. brevis, $\quad 22,39$ pallida (Brachypus) Guild. pontifica Gould, 217 prineeps $\mathrm{Ad}$. procera Ad. pupeformis $\Lambda$ d. pusilla Ad. pygmaa Ad. v. Geomelania p.

Robertsi $\Lambda$ d.

rusea $A$ d. v. $C$. carnea

" Pfr. 21, 22, 39, 82, 161, 183

a. var. magna Ad. $21,39,183$

b. var. major Ad. 21, 39, 161, 183

c. var. fortis Ad. 161,183

d. var, ambigua $\mathrm{Ad}$.

183

rubella Ad.

rubra Ad.

sanguinea Pfr.

seminuda Ad.

similis Ad.

simplex $\Lambda d$.

subula Fer.

tenella Ad.

tenera Ad.

39,183

$23,39,167,183$

$39,82,183$

39,182

$23,39,183$

$22,39,183$

39,182

$28,39,183$

$23,39,52,183$

variegata var. $\gamma$ l'fr. $39,47,176,182$ zonata Ad.

CyiT:ATDE,

Dentalid $F_{4}$

Dolium perdix,

Eulima aftinis Ad.

161,183

199,211

200

arenata $\mathrm{Ad}$.

conica $A d$.

gracilis Ad.

fulvo-cineta Ad.

F'usus decussatus Brown, nitens $A d$.

Gasterotoda,

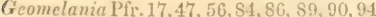

aininis $\Lambda \mathrm{d}$.

$197,199,200$

96,182

Beardsleana $\Lambda$ ?

$89,94,97,182$ eonica $\Lambda$ d.

costulosa $\Lambda d$.

$97,160,182$

$96,160,182$

elegans $A d .17,18,39,89,90,94,182$ exilis $\Lambda$ d.

$97,160,182$

expansa Ad.

$18,39,84,96,182$

fortis $\Lambda$ d.

94,182

gracilis $\Lambda \mathrm{d}$.

95,182

a. var. parea Ad.

95,182

Greyana (Cylindrella) Ad. 82, 182
Geomelania Hilliana $\Lambda d . \quad 159,160,182$

Jamaicensis Pfr. 17, 18, 39, 55, 182

magna Ad. 94, 182

media $\mathrm{Ad}$.

96,182

minor $\Lambda \mathrm{d}$.

$17,18,39,52,55,94,96,182$

pauperata $\Lambda \mathrm{d}$. $\quad 97,182$

procera Ad. 95, 182

pygnaea $\Lambda \mathrm{d}$. $\quad 89,97,182$

pyramidata Ad. $\quad 159,182$

striosa Ad. $\quad S 9,96,160,182$

typica Ad. $\quad 94,95,182$

a. var. pygman $A d . \quad 96,182$

vicina $\Lambda \mathrm{d}$. $\quad 96,182$

Glandina, 242

Granomiaculati, $\quad 200$

$86,98,200$

$16,51,181$

- aflinis Ad.
agglutinams Sowb.

albolabris $A d .13,14,16,52,135$, 181

ampliata $\Lambda$ d. $\quad 101,121,136,181$

1 aurantia Gray, $16,89,181$

- Brownii Gray, 13, 14, 16, 134, 181

castanea (?) Sowb. 217

eitrinolabris Ad. $\quad 14,16,181$

concentrica Pfr. 229

consanguinea Ad. $134,135,181$

a. var. suror $\mathrm{Ad}$. 135,181

- costata Sowb. 16, 51, 181

- depressa Gray, 16, 51, 136, 181 a. var. valida $\Lambda \mathrm{d}$. $\quad 136,181$

dubiosa Ad. 93, 181

a. var. intermedia Ad. 94,181

Gossci Pfr. $\quad 176,181$

Gruildingiana $\mathrm{P}$ fr.

hamastoma Moric. $\quad 47,51,89$

hirsuta Ad.

$133,135,181$

- Hollandi Ad. 13, 16, 88, 133, 181 Hornheckii Phil.

- Jamaicensis Sowb.

217

$16,51,101,136,1 \mathrm{S1}$

Josephine Ad. r. 'Trochatella J. 14

Leana Ad. v. H. depressa, 181

lineata $\Lambda$ d. $\quad 1$ i, 51,181

maeilenta $A d . \quad 13,16,101,181$

(1) Maxima Sowb.

$$
13,16,52,133,134,181
$$

a. var. cilrina $\Lambda \mathrm{d}$. 134,181

megastoma Al. $\quad 14,16,51,181$

mierostoma $\mathrm{Ad}$. $\quad 135,1 \mathrm{S1}$

neritella Lam. $16,-17,5 * 3,159,181$

a. var. angulata Ad. 159,181

nobilis Ad.

$133,134,181$

palliata Ad. $13,16,101,134,181$ a. var. labiusa $\Lambda \mathrm{d} . \quad 134,181$

picta Fér.

47,176

pusilla Ad.

101,181 
Helicina rotellina Mich.

- solitaria $\Lambda$ d. subfusca Mke. tenuis Ad. v. Trochatella $t$.

]6, $51,94,181$ 217 14 Helix acuta Lam.

$77,100,106,185,205,206$ a. var. acutissima Lam.

alligans Ad. $29,40,185,205,206$ alveus Ad. 105,186 amabilis A

80,185 ambigua Ad. 105 angustata Fer. 40, 49, 177, 185, 204 angustispira Ad. $\quad 36,41,186$ anomala Pfr. $\quad 40,78,171,185,206$ a. var. pallescens $\mathrm{Ad}$. 171,185 b. var. convexa Ad. 171, 185 Anthoniana Ad. $\quad 35,41,185$ apex Ad. $\quad 36,41,52,53,185$ arboreoides $\mathrm{Ad}$.

aspera Fer. $34,35,41,107,129,186$ atrata Pfr.

40,185

Bainbridgii Pfr. 40, 49, 171, 185, 205 a. var. pretiosa Ad. 171, 185, 204 bicanaliculata Fer. 225,227 Blandiana Ad.

Boothiana Pfr. brevior Ad. brevis Ad.

Bronni Pfr. $30,40,77,78,100,185,206$ Buddiana Ad. 171,185 candescens Ad. v. $H$. sinuata 80 cara Ad. 29, 40, 106, 169, 184, 206 a. var. media Ad. $\quad 169,184$ b. var. amabilis Ad. 105, 169, 184 Chemnitziana Pfr. chersina Say, Chittyana Ad. a. var, bicolor Ad.

$$
30,40,106,-169, \cdot 185,206
$$
columellata Ad. connectens Ad. consanguinea Ad. a. var. imperforata Ad. 171, 185 b. var. carinata Ad. 171, 185 Cookiana Fer. $31,41,186$ Cubensis var. o Pfr. $\quad 40,49,185$ depicta Grat.

depressa Ad. $\nabla$. H.brevior, 37, 41, 185 diminuta Ad. dioscoricola Ad. epistylioides Fer. epistylium Müll.

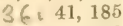
41,186 $41,105,186$ $31,34,41,105$, $107,173,174,186$ a. var. minor Ad. 173,186 b. var. delaminata Ad. 174, 186
Helix epistyliulum Ad. $\quad 31,41,186$ fluctuata Ad. v. H. Chemnitziana, $\quad 29,40,77,185,205$ Foremaniana Ad. $\quad 80,186$ formosa Fer. fortis Ad. fulva Müll. fuscocineta Ad. fuseolabris Ad. fuscula Ad.

Gibboni Pfr.

Gossei Pfr. graminicola Ad. Gundlachi Pfr.

Haldemaniana Pfr. Hollandi Ad. immunda Ad. incerta Fer. inconspicua Ad. $106,185,206$ $35,41,185$ 231

41,185 $32,41,185$ 224

129,186 $34,41,186$ $36,41,185$ $204,222,223$ $37,41,185$ ingens Ad. $\quad 76,108,170,185,205$ a. var. imperforata Ad. 170,185 b. var. indigna Ad. 170,185 invalida Ad. $\quad 79,80,185,206$ Jacobensis Ad. $\quad 172,185$ Jamaiccnsis Chem. $\quad 40,185,206$ labiatus Mont. 227 labyrinthus Chem. 232 lamellifera Ad. $\quad 31,41,186$ lima Fer. $\quad 204,222,223$ lucerna Müll. $\quad 40,106,185,206$ MacMurrayi Ad. $\quad 32,41,185$ magnifica Len, 231 Martiniana Pfr. $\quad 40,176,184$ minuscula Binney, $\quad 52$ monile Brod. 232 munda Ad. $32,33,41,171,185$ nemoralina Pet. 228 nemoraloides Ad. $\quad 41,185$ nobilis Ad. v. H. patina 106 Okeniana Pfr. $\quad 40,176,185,206$ opalina Ad. 186 Oreas Koch. $\quad 231,232$ osculans Ad. $\quad 107,174,186$ a. var. delaminata Ad. 174,186 paludosa Pfr. $\quad 186$ patina Ad. 29, 40, 77, 185, 205 a. var. nobilis Ad. $\quad 185$ pellucida Ad. v. II. Boothiana, 185 peracutissima Ad. $\quad 40,184,206$ peraffinis Ad. $37,41,173,185,223$ perdepressa Ad. $\quad 36,41,185$ picturata Ad. $30,40,78,84,98,99$, var. $a . \mathrm{Ad}$ $100,185,206$ pila Ad. planorbis Jay, plicaria Lam. $31,41,186$ plicata Born,

\section{2}

232 


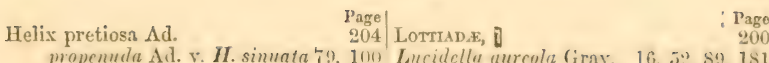

ptychodes Pfr. $\quad 41,185,223$ pulchella Müll.

pulchrior Ad.

pulla Gmel.

Redfieldiana Ad.

(H. Carmelita Fer.)

rufula Pfr.

52

172,185

185

107,185

185

Sehröteriana Pfr.

similis Ad.

simulans Ad.

sincera Ad.

sinuata Born,

"Chem.

var. Chem.

var. Deless.

var. Küster,

var. $\beta$ Pfr.

" Müll. $30,40,77,78,79$,

$85,98,100,185,191,206$

a. var. propemuda Ad. $\quad 185$

b. Var. candescens $\mathrm{Ad}$. $\quad 185$ sinuosa Gmel.

99

"Fer.

soror Fer.

Spengleriana Pfr.

spreta Ad.

a. var. errans Ad.

$29,40,184,206$

$40,1 \varepsilon 5,206$

173,185

squamosa Fer.

strangulata Ad.

subconica Ad.

subplanata Pet.

subpyramidalis Ad. v. II. turbiniformis,

sulphurea Ad. v. Dolium perdix,

$30,40,78,185$

$41,172,185$ 232

Swainsoniana Ad.

tenerrima Ad.

torrefacta Ad.

tridentina Fer.

tumida Pfr.

tunicata Ad. v. H. tumida, $33,41,171,185,188,206$ turbiniformis $\mathrm{P} \mathrm{fr}$,

$41,49,185$

valida Ad. $77,78,99,100,185,206$ virginea Ad.

Jamaicia, $33,41,98$ 169,185 $41,81,185$ $31,41,186$ $40,78,185$ 206 Lucina, a. var. granulos $\mathbf{A d}$. 89,181

Americana Ad.

anatellinoides $\mathrm{RV}$.

243,248

Antillarum Rv.

aurantia Desh.

Chemnitzii Phil.

divaricata Lin.

divaricata Rv.

eburnea Rv.

edentula (Venus) Lin.

exasperata liv.

funiculata Rv.

granulosa Ad.

imbricatula Ad.

Jamaicensis (Venus) Chent. 245

(V enus) Chem. 245

Janeirensis Rv.

lupinus Broc.

245,247

obliqua Rv.

245

occidentalis Rv.

246

ornata Ad.

245

ornata Rv.

243

pecten $\mathrm{R} \mathrm{v}$.

243

pectinata $\Lambda \mathrm{d}$.

245

pectinella $\mathrm{Ad}$.

245

Pennsylvanica (Venus) Lin. 246, 247

pilula Ad. 246

scabra Rv.

247

serrata Orb.

244

soror Ad.

subglobosa Ad.

247

tigerina (Vemus) Lin. $\quad 247$ var. 3 Lam. 244

virgo Rv.

247

Mangelia albovittata (Plcurotoma) $\Lambda \mathrm{d} .55$ badia Rv.

biconica Ad. var. alba Ad.

brevis Ad. candidissima (Plcurotoma) Ad. 55 crassieostata $\mathrm{Ad}$.

densestriata $\mathrm{Ad}$.

dubia (Pleurotoma) Ad.

Dysoni Rv.

fusca (Pleurotoma) Ad.

lanecolnta $\Delta \mathrm{d}$.

multilineuta (Pleurotoma) Al. 66

muricoides Ad.

trilineata (Pleurotoma) Ad. 55

vicina $\Lambda$ d.

Litiopa effusa Ad. obesa Ad.

LitToRINIDE,

Littorina carinata Orb. Jamaicensis Ad.

lineata Orb. ziczac Desh.

Lottio, $33,41,185$

$45,50,187$ 209

201
Marginclla abbreviata Ad. $\quad 56$ alba Ad. $\quad 56$

avena Val. $\quad 130$

fluetuata Ad. $\quad 56$

frumentum Sowb. $\quad 57$

gracilis Ad. 
Marginella lactea Kr. nivea Ad.

pruinosa Hinds, varia Sowb.

Megalomastoma Antillarum Gray,

Melampus, cinculatus $\mathrm{Pfr}$. coniformis Brug. coronatus Ad. favus Gmel. pusillus Gmel.

Melania spinifera Ad.

Meranid $F_{\text {, }}$

Melanopsis lincolata Gray,

Mitra albicostata Ad. cavea IRr.

leucodesma Rr. microzonias Lam. monilifern Ad.

Murex alveatus Kr. costellaris Lam. crosus Brod. intermedius Ad. pauperculus Ad.

MIURicid $x$,

MTTILID

NALAD ,

Nanina,

Narica anomala Ad.

Natica carrena Linn. Jamaicensis Ad. a. var. nigrescens $\Lambda$ d. proxima Ad.

\section{Nautilus}

Neritina Jamaicensis Ad. ornata Ad. punctulata Lam. pusilla Ad. tenebricosa Ar.

Odostomia eanaliculata $\mathrm{Ad}$ gemmulosa $\mathrm{Ad}$. ovuloides Ad. solidula Ad.

P.gunide,

Paludina Jamaicensis Ad. rivularis $\mathrm{Ad}$.

Partula auriculata Brod. diminuta Ad.

Patella, Otaheitana Brug.

Patellide,

Pectinibiancmitata,

Pedipes, ovalis Ad. quadridens $\mathrm{Pfr}$.

Phasianella aftinis $\Lambda$ d. brevis $A d$. concinna Ad.
Page

56 Phasianella concolor Ad.

56

56 130

216

47

42,186

42,186

$41,42,186$ 42,186 42,186 45,187 $86,190,209$ 45,187

60 Pleurobraxcirata, 200 Pleurotoma albella Ad. 198 albinodata Rv. $49,78,86,190 \quad$ alloviltata Ad. pulla Linn. tesselata Ad.

Philippia,

Pholas corticaria Gray, " Sowb. pusilla Linn. rosea Ad.

Pliysa Jamaicensis Ad. Sovcrbyana Orb.

Phytopilaga,

Planorbis affinis Ad. decipiens Ad. dentiferus Ad. Haldemani Ad. humilis Ad. lentus Say, MacNabianus Ad. pallidus Ad. Redfieldi Ad. vortex Müll.

Page 68 67 67 200

174,187 $45,50,187$ 200 $44,45,50,187$ 44 $43,45,187$ $45,132,187$ $43,45,187$ 131,187 44,50 $43,45,187$ $44,45, .187$ $43,45,187$

$$
43
$$$$
63,131
$$

55

200 Augustie Ad. 61

109 decorata Ad. 62

111 decussata Macgil]. 54

111 diminuta Ad. 62

112 flavocincta Ad. 63

111 fuscescens Gray, 62

199 fuscocincta Ad. 62

175,187 fuscolineata Ad. 54

112 fusiformis Ad. 64

$175,187 \quad$ Javana Ad. 61

112 luteofasciata Rv. 55

$175,187 \quad$ lymneiformis $\mathrm{Kr}$. 63

109 maculata Ad. 62

$109 \quad$ Maegillivrayi Ad. 54

109 minor Ad. 54

110 monilifera (Columbella) Sowb. 55

195 nigrescens Ad. 54

42, 45, 187 " Gray, 54

45, 187 nodata Ad. 64

125 patula $\mathrm{Rr}$. 63

125 plicata Ad. 54

$125 \quad$ plicosa $\Lambda$ d. 54

201 pygmax Ad. 63

$200 \quad$ quadrata RF. $\quad 62$

199 quadrilineata Ad. 64

47 Reerii Ad. 54

$41,42,186 \quad$ rustica Sowb. 62

$41,42,52,186 \quad$ scalpta liv. $\quad 54$

67 solida Ad. 61

67 symmetrica Rv. 65

69 trifasciata Gray, $\quad 55$ 
Pleurotoma trilincata $\Lambda$ d. unicolor Sowb. violacen Hinds, zelira Kr.

Potamomya,

Proserpina, bidentata Ad. diseoider $\mathrm{Ad}$. nitida Sowb. 2. var. plar opalina Ad. pisum Ar. pulchra Ad,

PtEropodi,

Pulmobr.inchiat.

Pupa contractu Say, decumana (Helix) Fer. cxigua Say, exilis Ad. fallax Say, hexodon $\mathrm{Ad}$. Jamaicensis $\Lambda$ d. 37,40 , lata $A d$. milium Gould, minutissima IIartm. ovata Say, procera Gould, servilis Gould, strialclla Fer. tenuidens Ad.

Purpura aberrans Ad. costularis RF.

Purpuridi,

Risson aberrans Ad. allicla Ad. dubiosa Ad. eulimoides Ad. levigata $\mathrm{Ad}$. levissimn Ad. melanura Ad. multicostata Ad. princeps Ad. pulchra Ad. scalurella Ad. sealaroides $A d$. a. var. minor $\mathrm{Ad}$. striosn $\mathrm{Ad}$. subangulata $\mathrm{Ad}$. lerraricosa $A d$. vitren $\Lambda \mathrm{d}$.

Rissnina

Brozoniana Orb. elegrantissima Orb.

Scalariu ligata $\Lambda d$. $41,81,82,174,186$ 81,186 81,186 nulats $\Lambda \mathrm{d}$. 174,186 $41,81,186$ 108,186 $81,82,186$ $197,198,201$ 200

$40,48,18$. 216 38

$38,40,18.1$ $40,48,184$ $37,40,181$

$52,53,181$ $37,40,184$ $52,53,71$

Solarium,

Spiraxis, aberrans $A d$.
Spiraxis aberrans

Page

a. var, unicolor $\Lambda d . \quad 168,184$

Spiraxis anomalus $\Lambda d$.

168,184

168,184

88,184

88,184

168,181

148

158,181

151,181

$16,52,181$

16,181

$16,52,181$

$\begin{array}{lr}\text { Fadycnianum Ad. } & 16,52,181 \\ \text { Gouldianum Ad. } & 16,52,149,181\end{array}$

Hollandianum Ad. 16, $22,149,181$

- Jayanum Ad.

- Lcanum Ad.

Lindsleyanum $\Lambda d$.

$16,52,181$

$16,52,181$

16,181

150,181

151,181

Petitianum Ad.

$P$ fcifferianum Ad.

Philippianum $\mathrm{Ad}$.

- pisum Ad.

$16,52,181$

$158,18 \mathrm{I}$

$16,52,181$

- Redficldianum Ad. 16, 52, 151, 181 succincum Somb.

148 Tappanianum Ad. Vilkinsonix Ad.

Streptaxis Candeana Pet.

149,181

148,181

StrovibiDs,

Strombiformis perversus $\mathrm{Da}$ Costa, 226

Succinea angustior $\Lambda$ d. $\quad 38,40,184$ avara Say, campestris Say, contorta $\Lambda d$.

40,184

latior $\mathrm{Ad}$. obliqua Say,

Tecturim

Terebra Jamaicensis Ad. $\quad 58$ stylata Hinds, $\quad 58$

Tornatellina Cubensis Pfr. $\quad 204$

Tr..cuel.tPoDA, $\quad 199$

Trid.cNid.E, $\quad 198$

Triton angulatus Rv. $\quad 60$ chrysostoma, $\quad 60$ parvus Ad. $\quad 59$ pulchellus Ad. $\quad 60$

Trochatella Grayana Pfr. 16, 176, 181 Josephine Ad. 14, 16, 52, 136, 181 a. var. pulchra Ad. 136,181 pulchella Gray, 16, 52, 136, 159, 181 a. var. multicarinata Ad.

159,181 b. var. nobilis Ad. 159,181 T'ankervillii Gray, 16, 52, 136, 181 var. a $\Lambda \mathrm{d}$. var. $\beta \Lambda \mathrm{d}$. 
Index.

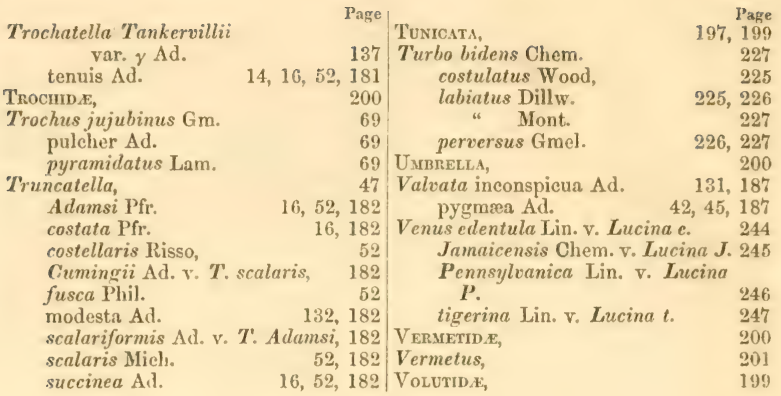







